\title{
O ver e o fazer dos mosaicos no espaço da arquitetura e da cidade
}

Stella Marina Rodrigues

\author{
Orientador: \\ Prof. Dr. Bruno Roberto Padovano \\ Dissertação de Mestrado \\ Faculdade de Arquitetura e Urbanismo \\ Universidade de São Paulo \\ São Paulo, 2007
}




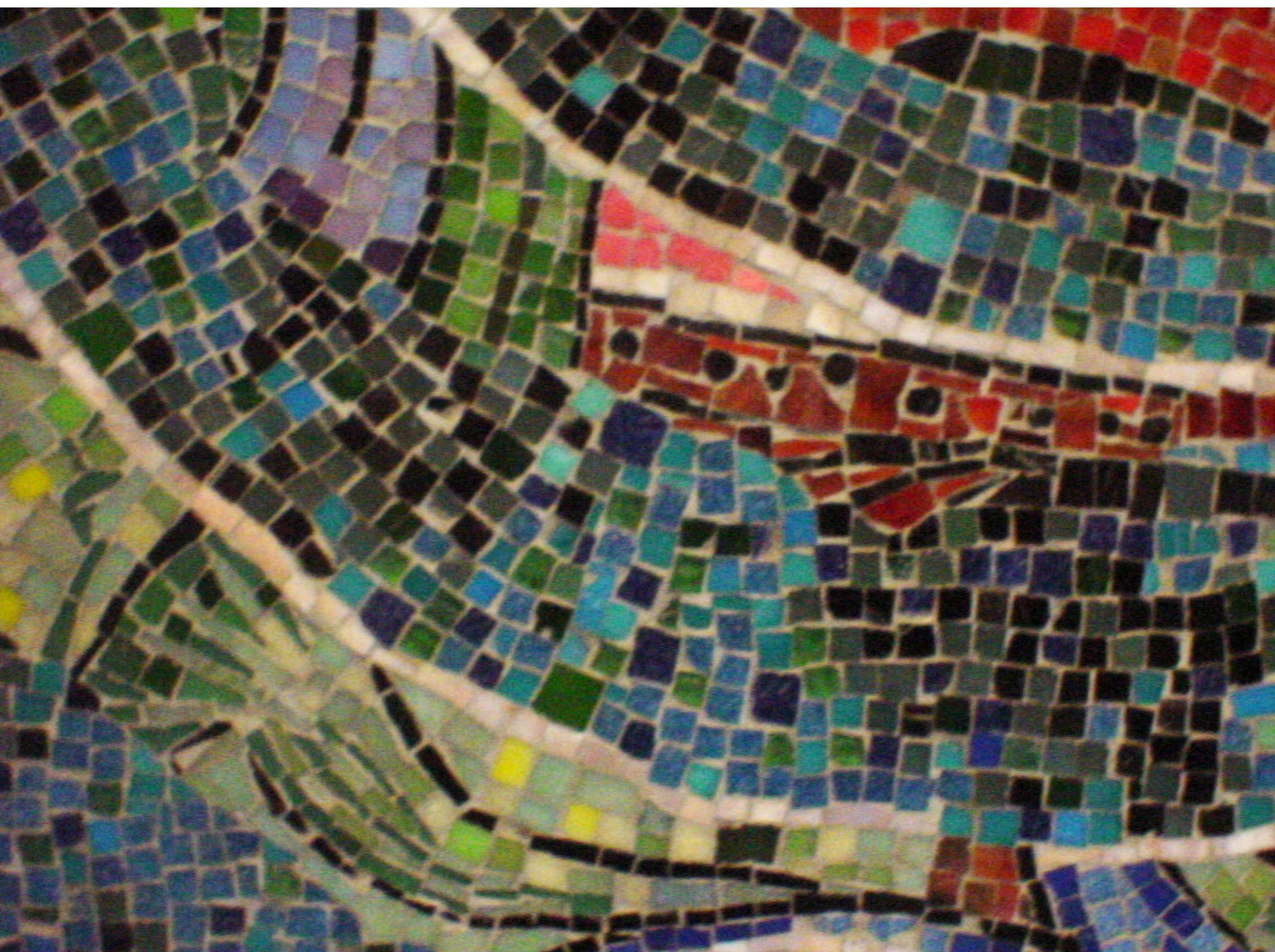




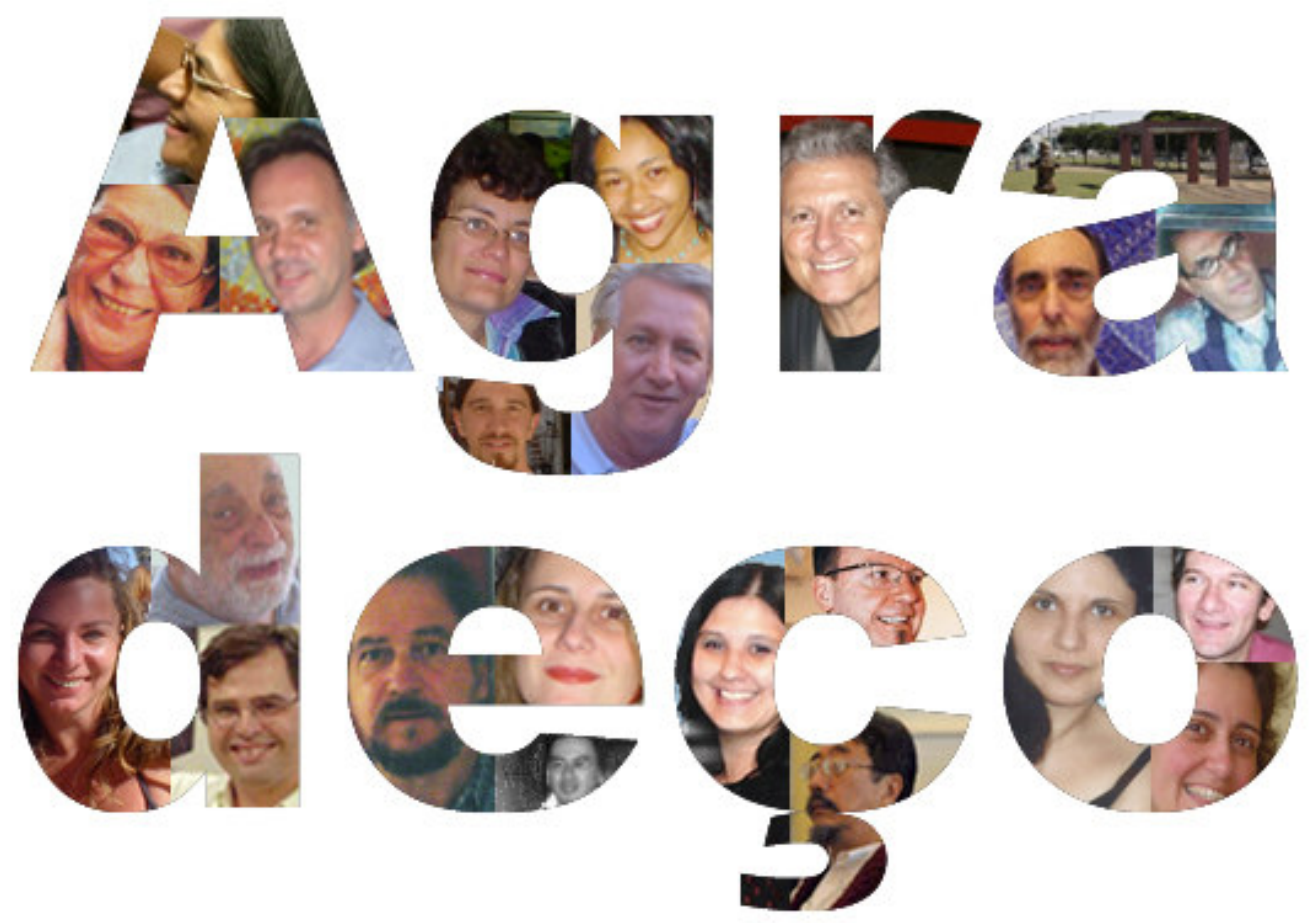




\section{Resumo}

Este estudo visa o reconhecimento do valor artístico dos mosaicos e da importância do espaço onde estão inseridos. Para isso foram enfocadas as questões do ver mosaicos, que implica seu entendimento como objetos compostos de diversas partes, e do fazer mosaicos, que abrange as questões técnicas de projeto e execução. $O$ espaço é apresentado como elemento essencial na hora de ver mosaicos, visto que os mosaicos transformam o espaço e, também, no sentido contrário, o espaço transforma o mosaico. Na questão de fazer mosaicos, na fase do projeto, exige-se um estudo do espaço em que ele será aplicado. Este trabalho inclui uma amostra de mosaicos de pastilha de vidro em seu espaço na cidade e em edifícios com fotos e ilustrações, visando transportar o leitor para esses espaços, e para os pontos de vista de um mosaicista e de um artista plástico, que projeta murais para espaços públicos. 


\section{Abstract}

This study aims at the recognition of the artistic value of mosaics and of the importance of the space into which they are introduced. To achieve this purpose, focus is directed at issues relating to the seeing of mosaics - which implies their being understood as objects composed of diverse parts - and of the making mosaics, which involves technical questions having to do with project and execution. The space is presented as an essential element at the moment in which the mosaic is seen - once the mosaic transforms the space - as well as, in the contrary sense, the space transforms the mosaic. The problem of making mosaics in the project phase demands a study of the space in which it will be applied. This work includes a sample of glass tile mosaics in their space in the city and building, with photos and illustrations, aiming transporting the reader into these spaces, and into the point of view not only of the mosaicist, but also of the plastic artist, who projects murals onto public spaces. 


\section{Sumário}

Introdução .1

1. Ver mosaicos ............................................................

1.1. Definição de mosaico .................................... 7

1.2. Etimologia ................................................... 11

1.3. Origens ........................................................ 13

1.4. Aplicações dos mosaicos .................................... 16

1.4.1. Mosaico artístico (independente) ..........................20

1.4.2. Mosaico sendo arquitetura .................................20

1.4.3. Mosaico decorativo na arquitetura...........................22

1.4.4. Mosaico decorativo em objetos ...........................23

1.4.5. Mosaico para comunicação visual ........................26

1.4.6. Mosaico digital ..................................................27

1.4.7. Mosaico em performances .................................32

2. Fazer mosaicos..........................................................34

2.1. Métodos de colocação.......................................34

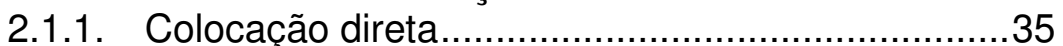

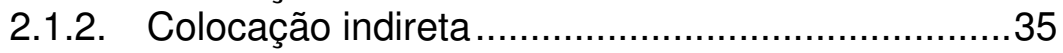

2.2. Sistemas de colocação.......................................37

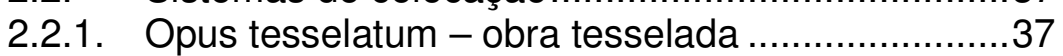

2.2.2. Opus vermiculatum - obra vermiculada ................39

2.2.3. Opus sectile - obra marchetada ............................4 41

2.3. Execução do painel .......................................... 42

2.3.1. Projeto ........................................................ 42

2.3.2. Preparação do cartão ..........................................46

2.3.3. Estudo cromático ..............................................47

2.3.4. Corte das pastilhas ...........................................48

2.3.5. Colocação das pastilhas .........................................49

2.3.6. Colagem das pastilhas no papel.........................51

2.3.7. Colocação do mosaico no painel ...........................51

2.3.8. Retirada do papel e finalização ............................52 
2.3.9. Considerações sobre a execução do painel ..........53

2.4. Execução do mural .............................................54

2.4.1. Projeto ......................................................... 54

2.4.2. Preparação do cartão ........................................55

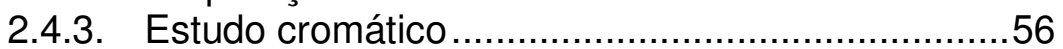

2.4.4. Corte das pastilhas ...........................................56

2.4.5. Colocação das pastilhas .....................................57

2.4.6. Colagem das pastilhas no papel..........................58

2.4.7. Colocação do mosaico na parede ........................58

2.4.8. Retirada do papel e finalização ............................59

2.4.9. Considerações sobre a execução do mural...........60

2.5. O fazer mosaicos por Sérgio Secches...................61

2.5.1. Perfil de Sérgio Secches ...................................62

2.5.2. Participação em concursos..................................63

2.5.3. Faculdade de arquitetura ..................................64

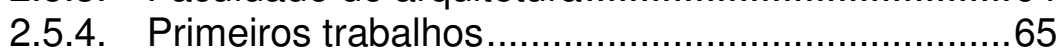

2.5.5. Serafino Faro ..................................................67

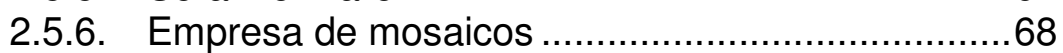

2.5.7. Mosaicos decorativos ........................................68

2.5.8. Mosaicos de outros artistas ................................69

2.5.9. Cores no mosaico...............................................70

2.5.10. O mosaico em seu contexto .................................70

2.5.11. Mosaicos em painéis móveis ....................................71

2.5.12. Senso comum................................................... 72

2.5.13. Picasso no painel e Dalí no banheiro ....................73

2.5.14. O que é mosaico ..............................................74

3. Espaço dos mosaicos...............................................75

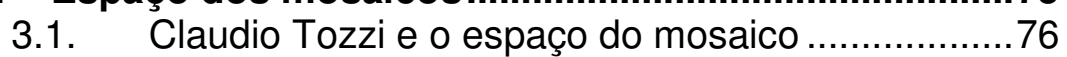

3.1.1. O projeto ....................................................... 76

3.1.2. O espaço ................................................... 77

3.1.3. O trabalho interdisciplinar .................................78

3.1.4. Questões da construção....................................79 
3.1.5. O material .....................................................79

3.1.6. O processo de reprodução da imagem ..................80

3.2. Teatro Cultura Artística....................................... 82

3.3. Residência Michel Abujamra ............................... 85

3.4. Hotel Jaraguá .................................................. 88

3.5. Residência Olívio Gomes .................................92

3.6. Centro Empresarial Itaúsa ...................................96

3.7. Edifício Montreal ............................................100

3.8. Edifício Califórnia.............................................104

3.9. Edifício Triângulo..............................................107

3.10. Residência na Rua Filadelfo Azevedo ..................112

3.11. Estação Sé ......................................................115

3.12. SESC Consolação ..........................................119

3.13. Estação Consolação.........................................122

3.14. Estação Santo André.......................................126

3.15. Cultura Inglesa ........................................... 129

3.16. Seguradora Porto Seguro................................134

3.17. Centro Cultural Dragão do Mar............................138

3.18. Novotel ...........................................................142

3.19. Terminal de ônibus de Santo Amaro ...................147

3.20. Centro Empresarial Itaúsa 2 ..............................151

3.21. Edifício Exclusive.............................................156

3.22. Forum Trabalhista ........................................160

Considerações finais......................................................164

Bibliografia ..........................................................................171

Lista de figuras ...........................................................180 


\section{Introdução}

Comece pelo começo e prossiga até
chegar ao fim: então pare.

- Lewis Carroll ${ }^{1}$

Esta dissertação trata dos mosaicos no espaço da arquitetura e da cidade abordando as questões de ver e fazer mosaicos. Mosaicos estão presentes no espaço de diversas formas, entre elas, como murais e painéis artísticos na arquitetura. É conhecida a importância da conjunção entre artes plásticas e arquitetura. Os murais têm como intenção interagir com os transeuntes e o espaço urbano.

Apesar de o espaço da obra de arte ser importante para o seu entendimento, a grande maioria dos seus registros

${ }^{1}$ Durante o julgamento do Valete de copas, acusado de roubar as tortas da Rainha, o Coelho Branco pergunta por onde deveria começar a ler uma carta, supostamente de autoria do Valete, e o Rei responde com esta citação. CARROLL, Lewis. Alice no País das Maravilhas, Lisboa: Publicações Dom Quixote, 2000. 
fotográficos limita-se a retratar a obra, esquecendo o seu espaço. O observador dessas imagens fica sem uma noção mínima de como é o espaço desta obra, qual é o seu tamanho e como é a sua interação com as pessoas.

São Paulo concentra uma quantidade notável de murais feitos em mosaico de pastilha vítrica. A presença dos artistas Alex Flemming, Bramante Buffoni, Candido Portinari, Cláudio Tozzi, Clóvis Graciano, Emiliano Di Cavalcanti, Herson Roitman, Odiléa Toscano, Tomie Ohtake e Vik Muniz na produção destes mosaicos torna São Paulo uma importante referência no Brasil.

Um fator motivador para escrever sobre mosaicos no espaço da arquitetura e da cidade foi a necessidade de reconhecimento do valor artístico dos mosaicos. Não é raro ir a um lugar onde se encontra um mosaico com um reconhecido valor artístico e sua presença ser desconhecida pelas pessoas que o vêem diariamente. As vezes o descaso é constatado pela disposição de elementos que obstruem a visão do mosaico, em casos mais graves, mosaicos de 
reconhecido valor artístico chegam a ser depredados ou até completamente destruídos.

A falta desse reconhecimento também acarreta dificuldades para os ateliês oferecerem mosaicos artísticos ao público. São elas: a aceitação muito pequena no mercado das artes, o que dificulta a venda de painéis em mosaico do mesmo modo que são vendidas pinturas em tela e o fato de a mesma técnica ser aplicada a trabalhos artesanais, o que faz com que haja uma tendência de generalização, fazendo com que mosaicos de todo tipo sejam vistos como artesanato. $O$ custo elevado do material e o logo tempo empregado também aumentam essa dificuldade.

O interesse pelo tema tem também um caráter pessoal, que se intensificou com a experiência da autora como participante do concurso Prêmio Quota de Arte, que escolheu o mural do Edifício Exclusive, realizado em 2002, em São Paulo, para o qual apresentou o projeto de mosaico Bromélias, selecionado entre os trabalhos escolhidos para a última etapa (foram 506 inscritos). O projeto vencedor foi o 
mural de Cláudio Tozzi, executado em 2003, que é citado, mais adiante, neste trabalho.

Esta dissertação está dividida em três capítulos, Ver mosaicos, Fazer mosaicos e Espaço dos mosaicos.

O primeiro capítulo, Ver mosaicos, serve como uma apresentação dos mosaicos, inclui as definições, tanto no sentido literal, que é o que se aborda aqui, quanto os outros usos, as origens e uma classificação do tipo de aplicação pelo tipo de objeto e seu uso.

No capítulo seguinte aborda-se uma breve explicação de como são feitos mosaicos, seguida de uma demonstração detalhada da execução de dois mosaicos. O primeiro, Laços, painel móvel de $105 \times 80 \mathrm{~cm}$, foi feito especialmente para demonstrar a técnica neste trabalho e o segundo é um mosaico de Claudio Tozzi de grandes proporções para a parede externa de uma capela.

Se fosse apenas para demonstrar a aplicação de uma técnica para fazer mosaicos, bastaria registrar a execução 
de um dos mosaicos. Porém, aqui o fazer não se restringe ao trabalho manual, como acontece em diversas

publicações. Ao fazer um mosaico é preciso estar pensando em seu espaço com relação ao observador, por isso o fazer abrange também o trabalho mental.

Para encerrar o segundo capítulo, a autora incluiu as questões levantadas em conversas com o artista plástico Claudio Tozzi, autor de diversos mosaicos, e com Sérgio Secches, mosaicista.

No terceiro capítulo mostramos alguns trabalhos em mosaico de doze artistas representativos feitos em pastilhas de vidro no espaço da arquitetura e da cidade. A maioria destes trabalhos está concentrada na cidade de São Paulo, mas também foram incluídos três em outras cidades, um de Roberto Burle Marx, em São José dos Campos, SP, cidade muito próxima de São Paulo, outro de Alex Flemming, em Santo André, cidade da Grande São Paulo, e outro de Aldemir Martins em Fortaleza, CE. Este último foi executado em um ateliê na Grande São Paulo, uma vez que o artista 
vivia em São Paulo. Os trabalhos estão em ordem cronológica.

Para entender melhor como os murais e painéis em mosaico participam do espaço da arquitetura e da cidade, além de fotografias, são apresentados desenhos onde são destacadas as linhas principais dos espaços retratados. $\mathrm{Na}$ maior parte dos desenhos também são representadas pessoas, as quais, além de servirem como escalas humanas, ajudam-nos a perceber como é sua interação com os mosaicos em seu espaço. 


\title{
1. Ver mosaicos
}

\author{
Sou essência, sou imagem \\ Sou colagem \\ Sou moderno, sou arcaico \\ Sou mosaico \\ - Marcelo Quintanilha
}

\subsection{Definição de mosaico}

O mosaico pode ser definido como uma composição de diversas peças sobre uma superfície. A seguir estão algumas definições encontradas em fontes diversas.

"Embutido de pequenas pedras, ou outras peças de cores, que pela sua disposição aparentam desenho."

(Dicionário Aurélio)

\footnotetext{
${ }^{2}$ Mosaico. Marcelo Quintanilha. Mosaico. Faixa 1, Casa da Canção Produções Artísticas e Páginas do Mar Publicidade e Edições Musicais, 2005.
} 
"Mosaico é a composição plástica que consiste em pequenas peças de pedra, vidro e cerâmica, de várias cores, coladas sobre uma superfície."

(Enciclopédia Barsa)

"Entende-se por mosaico uma composição decorativa em duas ou mais cores, feita com pequenos cubos, ou pedrinhas de forma irregular, que podem ser de pedra natural, terracota, cerâmica, massa vidrosa ou mármore, fixados sobre uma superfície estável, por meio de cimento, argamassa, estuque ou outras composições plásticas colantes."

(Mucci. A arte do mosaico)

As peças e as superfícies de um mosaico podem ser de materiais e formas variados, até mesmo pedaços de papel colados sobre outro papel, porém, o uso da pedra é bastante significativo e, por isso, é sempre salientado quando são apresentadas as definições de mosaico. Porém, é bom ressaltar que o significado essencial de mosaico está no tipo de composição e não no material. A enciclopédia on-line Wikipédia assim expressa: 


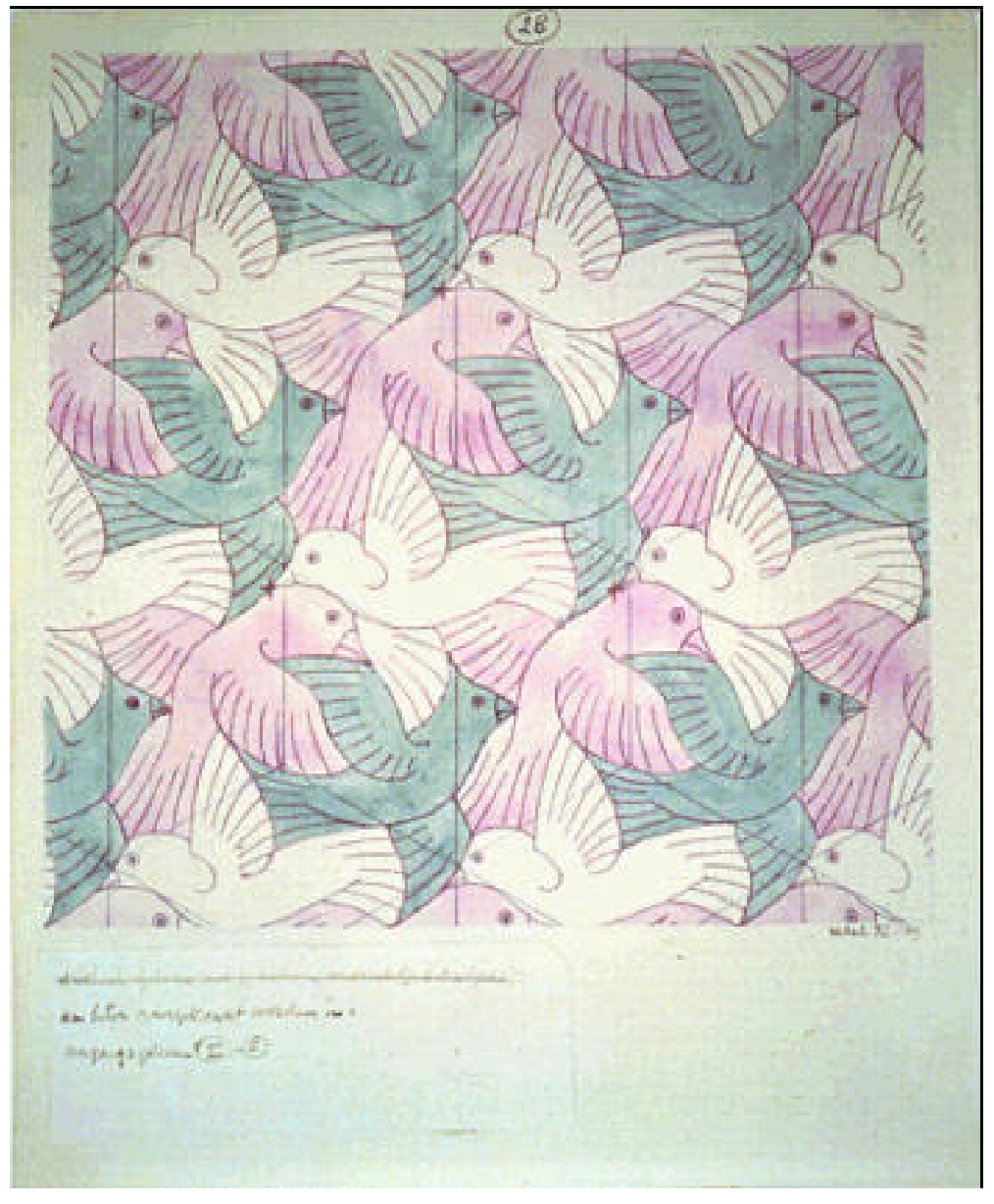

Figura 1 - Desenho de M. C. Escher com pássaros, onde é possível observar o padrão geométrico. (Fonte:

www.mcescher.com)
"São exemplos de mosaico o calçadão de Copacabana, a disposição dos pisos e azulejos de uma casa, até mesmo algumas gravuras do artista holandês M. C. Escher que tratam do preenchimento do plano."3

As gravuras/mosaico de Escher (1898-1972) são formadas por figuras de animais e pessoas baseadas em padrões geométricos inspirados nos mosaicos que ele conheceu durante suas duas visitas, em 1922 e 1936, a Alhambra, um complexo de palácio e fortificações dos séculos XIII e XIV, feitas durante as invasões árabes à província de Granada, no sul da Espanha. Os mosaicos dos árabes não apresentam desenhos figurativos, apenas geométricos, devido à proibição deste tipo de representação pela religião muçulmana. Escher escreveu em seu diário durante a primeira viagem:

“Era espantosamente oriental. O estranho para mim era a grande fartura de decoração, e a grande beleza digna e simples do todo. Aqueles árabes eram

\footnotetext{
${ }^{3}$ WIKIPÉDIA. http://pt.wikipedia.org/wiki/mosaico. Acesso em: 27 nov. 2006.
} 
aristocratas, como não mais são encontrados hoje. $A$ coisa estranha da decoração moura é a total ausência de qualquer forma humana ou animal - até, quase, a forma de qualquer planta. Talvez isso seja uma força e uma fraqueza ao mesmo tempo." 4

Logo após sua segunda visita a Alhambra, Escher criou um sistema que servia como um guia para fazer divisões regulares do plano, o que resultou em seus diversos mosaicos gráficos.

Existem outros usos para a palavra mosaico. Em matemática, mosaico é o estudo do preenchimento do plano com figuras geométricas, sendo utilizado para estudar conceitos de área e ângulos, por exemplo.

A palavra mosaico também é amplamente utilizada em um sentido figurado significando um trabalho, intelectual ou manual, composto de diversas partes distintas.

${ }^{4}$ LOCHER, J.L., Escher - the complete graphic work. Holanda: Thomes and Hudson, 1992. 
Em muitas publicações e anúncios publicitários, revestimentos lisos de pastilhas de vidro são apresentados como mosaico. Este emprego da palavra mosaico, de acordo com as definições de dicionários e enciclopédias, não está errado, visto que as pastilhas de vidro apresentam pequenas variações de cores. Porém, o mosaico resultante não é fruto de um trabalho mental, em que o artista toma uma decisão para a colocação de cada pastilha que o compõe.

Se entendemos que a essência de um mosaico está no modo em que ele é feito, é impossível entender como tal os mosaicos que são criados pelo acaso, pela natureza e por máquinas. Por isso, para esta dissertação, vamos considerar as definições de mosaico existentes, porém, limitando-as aos mosaicos criados por pessoas.

\subsection{Etimologia}

Existem diferentes definições para a origem da palavra mosaico, poderia ter vindo do latim medieval musaicus, de musa, ou do grego mouseîn, tendo o mesmo significado. 
Existe também a possibilidade de a palavra mosaico ter sofrido uma confusão meramente formal com mwoaïxoc, que seria relativo a Moisés, porém esta origem é considerada improvável. ${ }^{5}$

A palavra mosaico é de origem grega e provém da forma antiga Movoaïxov (mosaicon) que significa "paciente, digna das Musas".

Paciente, porque requer muita paciência e muita atenção para executa-la.

Digna das Musas, porque se trata de um trabalho de rara beleza, feito com materiais que duram séculos e por isso tem um sentido de eternidade, isto é, de divino. ',

As musas são divindades da mitologia grega. Após a vitória dos Olímpicos sobre os Titãs, havia sido solicitado a Zeus que ele criasse divindades que fossem capazes de

\footnotetext{
${ }^{5}$ MACHADO, José Pedro. Dicionário Etimológico da língua portuguesa. Lisboa, Editorial Confluência, 1959.

${ }^{6}$ Mucci, Alfredo. A arte do mosaico - compêndio histórico-técnico da arte musiva. Rio de Janeiro: Ao Livro Técnico, 1962. p. 15.
} 
cantar ao mesmo nível deste mérito. Zeus passou, então, nove noites consecutivas com Mnemósine, deusa da memória, e, um ano depois, nasceram Calíope, Clio, Érato, Euterpe, Melpômene, Polímnia, Tália, Terpsícore e Urânia, as nove musas. Elas cantavam e dançavam para o deleite das outras divindades. Música e museu também pertencem à mesma família etimológica de musa, música é o que concerne às musas e museu é onde residem as musas.

\subsection{Origens}

Não existe um consenso sobre onde e quando se originaram os primeiros mosaicos. É certo que o mosaico já tem mais de 5000 anos de existência. Por esta dissertação tratar de mosaicos dos séculos XX e XXI, esta discussão não cabe aqui. É interessante observar como as origens dos mosaicos influenciaram os mosaicos que vieram a seguir e qual foi a motivação para tantas civilizações terem feito seus mosaicos e para estarem presentes até os dias de hoje. 
Antonie - Chrysostome Quatremère de Quincy, arqueólogo e escritor francês, supõe que o mosaico tenha começado com a pavimentação de ruas com pedras porque a partir daí começou-se a fazer composições de pedras com cores diferentes. Estas composições se tornaram cada vez mais decorativas e cada vez mais elaboradas, até obterem valor artístico.

A pedra, mesmo não trabalhada, carrega uma significação simbólica originada nas civilizações primitivas que as consideravam moradas de espíritos e deuses. $O$ emprego da pedra como lápides e objetos de veneração religiosa pode ser entendido como uma forma primitiva de escultura, em que é atribuído à pedra um valor expressivo maior do que aquele que é encontrado na natureza. ${ }^{7} \mathrm{Na}$ opinião de $\mathrm{Mucci}^{8}$, era natural que o homem um dia tivesse vontade de transformar pintura em pedra.

\footnotetext{
7 JUNG, Carl G. O homem e seus símbolos. Rio de Janeiro: Editora Nova Fronteira, 1964.

${ }^{8}$ Mucci, Alfredo. A arte do mosaico - compêndio histórico-técnico da arte musiva. Rio de Janeiro: Ao Livro Técnico, 1962. p. 19.
} 
"Mas, aprofundando-nos um pouco mais nesta opinião puramente técnica, podemos chegar à hipótese lógica que, da necessidade de transformar a pedra em pintura tenha nascido a idéia da composição musiva, isso é, à reconstrução artística de uma nova pedra, por meio de um conjunto ilimitado de várias pedras, à criação de uma policromia nova, ordenada pela mente do homem, formada pelas várias cromias líticas existentes na natureza, enfim, uma pedra feita de outras pedras, nova de forma, de aspecto, de cor, inexistente na ordem normal da natureza, mas sendo sua parte integrante."

No que se refere especificamente aos mosaicos de pastilha de vidro, é indispensável citar os bizantinos. Nos mosaicos bizantinos eram utilizadas tesselas de pastas vítreas ou esmaltes, "smalti". A fabricação do material se dava por compressão da pasta de vidro misturado com corante entre duas placas de mármore. Depois de solidificada, a lâmina de vidro de cerca de um centímetro de espessura era cortada com abrasivos ou martelinho em cubinhos. Hoje em dia este mesmo tipo de material é 


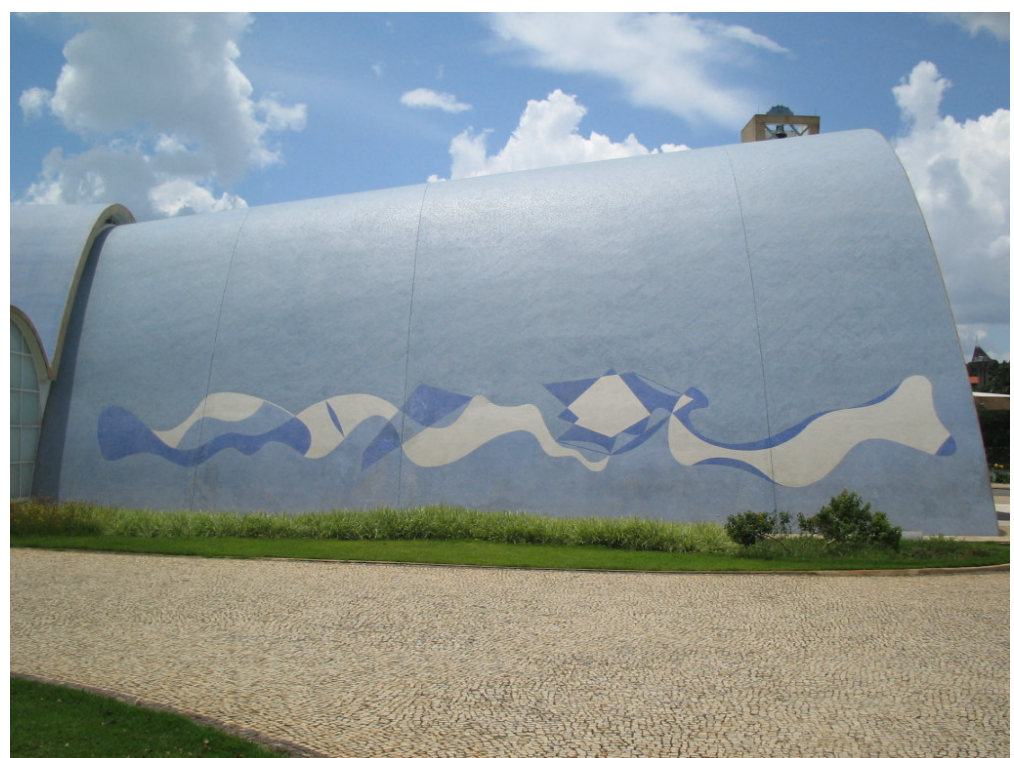

Figura 2 - Mosaico de pastilha cerâmica de Paulo Werneck na Igreja da Pampulha. (Foto de José Carlos Rodrigues) produzido industrialmente em formato padrão de $2 \times 2 \mathrm{~cm} \mathrm{e}$ espessura de $5 \mathrm{~mm}$, além de outras dimensões e formas.

Os bizantinos também utilizavam tesselas de ouro, "smalti-oro", que eram produzidas de modo similar, ou seja, sobre uma lâmina de vidro feita sem corante era colada com goma uma folha de ouro, que, depois, voltava ao forno com mais uma camada de vidro sobre a mesma para fixar, sendo posteriormente cortados os cubinhos.

\subsection{Aplicações dos mosaicos}

As superfícies às quais os mosaicos se aplicam podem ser variadas, desde objetos até edifícios.

$\mathrm{Na}$ arquitetura, o mosaico além de se manifestar como arte ou ornamento, também desempenha o papel de revestimento. A relação dos mosaicos com a arquitetura é muito próxima, a arquitetura serve como suporte para o mosaico enquanto o mosaico também é um material da arquitetura. 


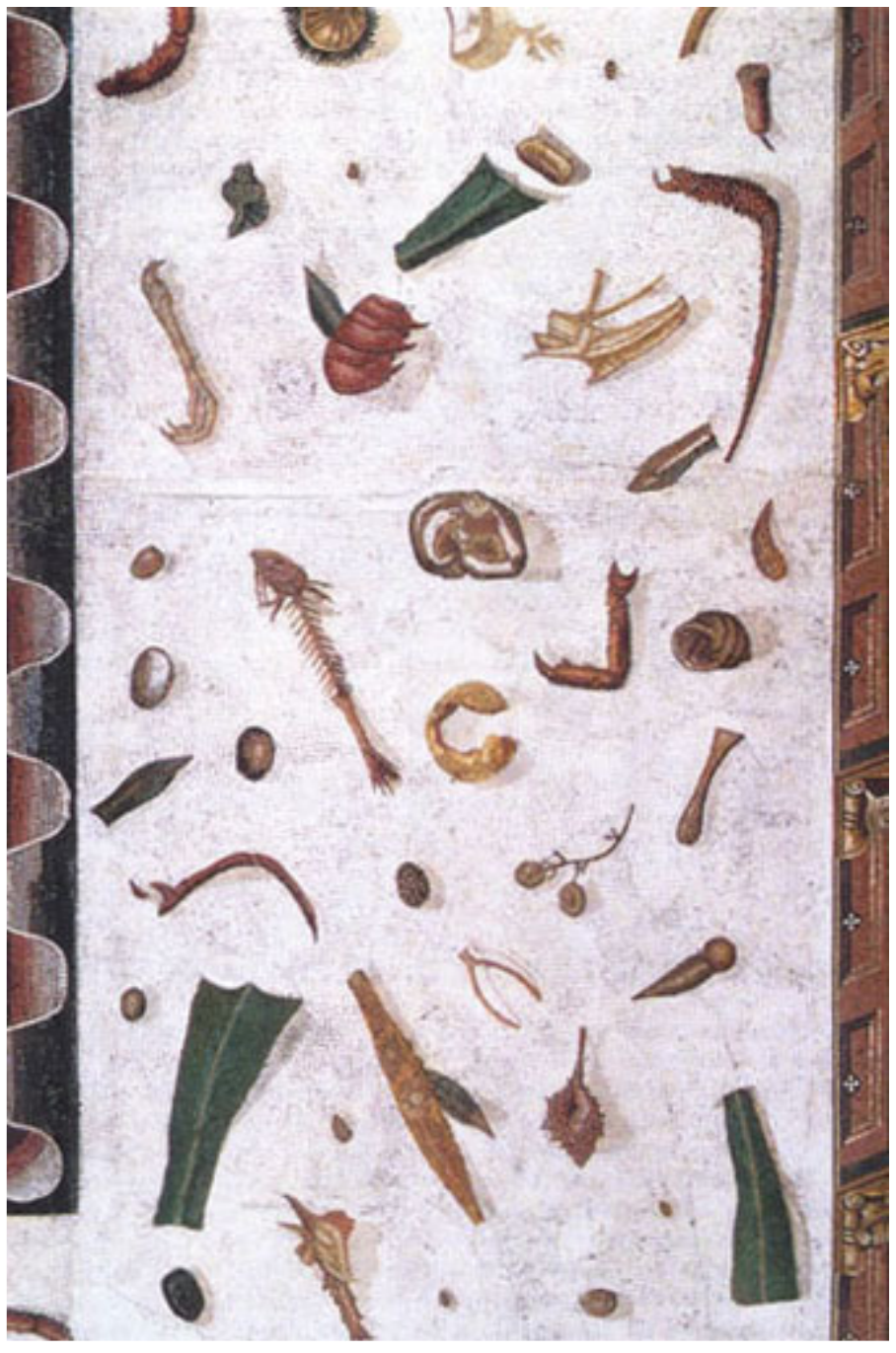

Figura 3 - Quarto por varrer, de Sosos de Pérgamo, Il a.C.
O arquiteto Oscar Niemeyer (1907-) procura definir o espaço da obra de arte durante o processo projetual. A Igreja de São Francisco de Assis ${ }^{9}$, uma de suas obras, tem um mosaico de pastilha cerâmica de Paulo Werneck (1907-1987) aplicado sobre uma superfície curva, apresentando curvas brancas e azuis livres sobre o fundo azul-claro.

\section{A relação entre a obra de arte e o espaço da} arquitetura é antiga; no século II a.C., o artista Sosos de Pérgamo executou alguns dos mosaicos figurativos mais antigos dos quais se tem conhecimento, entre eles, Quarto por varrer, que mostra as sobras de um banquete espalhadas pelo chão. Esta composição, apesar de ter um tema despojado, ainda apresenta uma rigidez semelhante à dos mosaicos com temas geométricos, visto que os elementos estão dispostos de uma maneira organizada. Houve um cuidado em reproduzir as sombras dos objetos para obter um resultado mais próximo da realidade. ${ }^{10}$

\footnotetext{
${ }^{9}$ Também conhecida como Igreja da Pampulha, em Belo Horizonte, construída em 1945 e restaurada em 2005. No mesmo local também está um painel de azulejos de Candido Portinari (1903-1962).

${ }^{10}$ CHARBONNEAUX, Jean; MARTIN, Roland; VILLARD, François. Grèce hellénistique: 330-50 av. J.-C. Paris: Éditions Gallimard, 1987.
} 
Antigamente, pintura, escultura e arquitetura não tinham limites definidos entre si. A divisão entre arte e arquitetura ocorreu no século XVIII, com o método das belas artes, isolando cada arte em seu sistema disciplinar. Com essa especialização e com a ascensão da arquitetura moderna, o trabalho do arquiteto passou a ser cada vez mais relacionado com os elementos construtivos. Por isso, ao falarmos de mosaicos artísticos na arquitetura, tem-se a impressão de que estamos falando sobre 'arte na arquitetura', o que seria um erro por arquitetura ser arte. Na verdade, estamos falando sobre a síntese das artes, que se dá quando pintura e escultura (ou mosaicos artísticos) tornam-se parte de uma composição arquitetônica.

De acordo com o arquiteto Jose Luis Sert, existem três modos de combinar pintura e escultura com arquitetura. $\mathrm{O}$ primeiro é quando o arquiteto também é o escultor e o pintor e, por isso a relação é de uma aproximação integral, como ocorria na Renascença e na Art Nouveau. O segundo é a aplicação destes elementos como ornamento, neste caso o artista não é independente, pois deverá seguir a determinação do arquiteto. E o terceiro é o de independência 
das partes, onde o artista plástico e o arquiteto se expressam no mesmo local. ${ }^{11}$

Tendo por base esses três tipos de combinação, podem-se classificar os mosaicos pelo tipo de aplicação como artística (independente), a própria arquitetura e decorativo na arquitetura. Além destas, devem ser acrescentadas mais quatro tipos de aplicação, decorativa em objetos, para comunicação visual, os mosaicos digitais e, por último, os mosaicos em performances.

Nesta classificação, não é definido se o trabalho em mosaico é ou não de boa qualidade, embora, em alguns casos, haja uma predisposição do observador em julgar a qualidade do trabalho pelo tipo de aplicação. Em alguns casos, um mesmo mosaico pode encaixar-se nas características de mais de uma aplicação.

\footnotetext{
${ }^{11}$ MELO, Magda M. "Síntese das artes na arquitetura de Oscar Niemeyer”. Semina: Ciências Sociais e Humanas, Londrina, (24): 121-130, set. 2003.
} 


\subsubsection{Mosaico artístico (independente)}

Aplicado em murais, painéis e esculturas, estes trabalhos são executados com o artista pensando ou não no

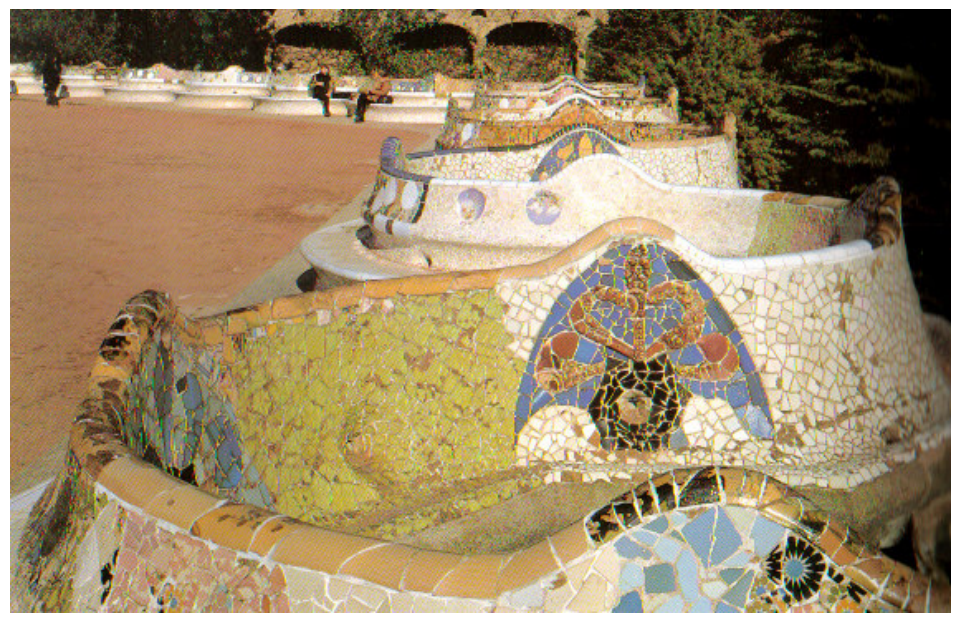

Figura 4 - Mosaico aplicado no Parque Güell, de Antoni Gaudí. (Fonte: ZERBST, Rainer. Gaudí 1852 - 1926: Antoni Gaudí Cornet - Uma vida na arquitectura. Japão: Taschen, 1985.) local onde ele estará aplicado. Quando isso é pensado, o mosaico não é uma obra que utiliza a arquitetura como suporte, mas sim um elemento em harmonia com a arquitetura. Os murais e painéis artísticos trazem consigo a expressão livre do artista e, por isso, podem ser analisados tanto no espaço da arquitetura e da cidade, quanto isoladamente.

\subsubsection{Mosaico sendo arquitetura}

Em alguns casos o mosaico não pode ser observado de forma isolada da arquitetura, como acontece com os murais em mosaico, que, se fossem retirados da arquitetura, esta continuaria existindo e, também, o oposto. Isso acontece quando o mosaico é mais do que um elemento que compõe uma obra, mas a obra em si é um mosaico, ou por ser 


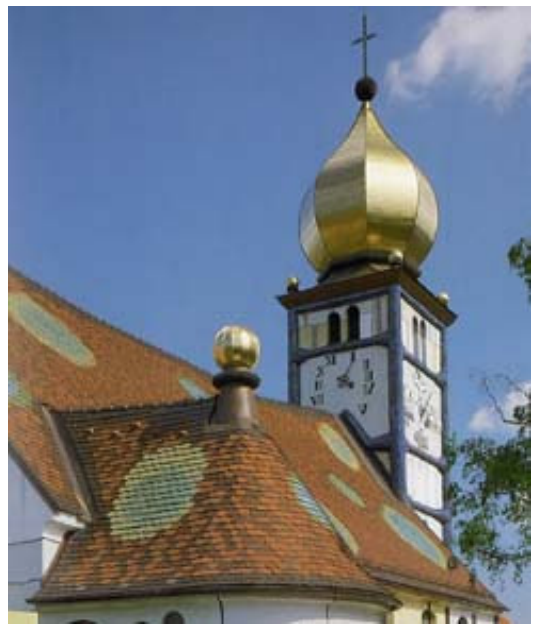

Figura 5 - Mosaico de janelas no edifício residencial Hundertwasser House, Viena, 1983-1986. (Fonte:

www.kunsthauswien.com/e nglish/hundertwasser.htm)

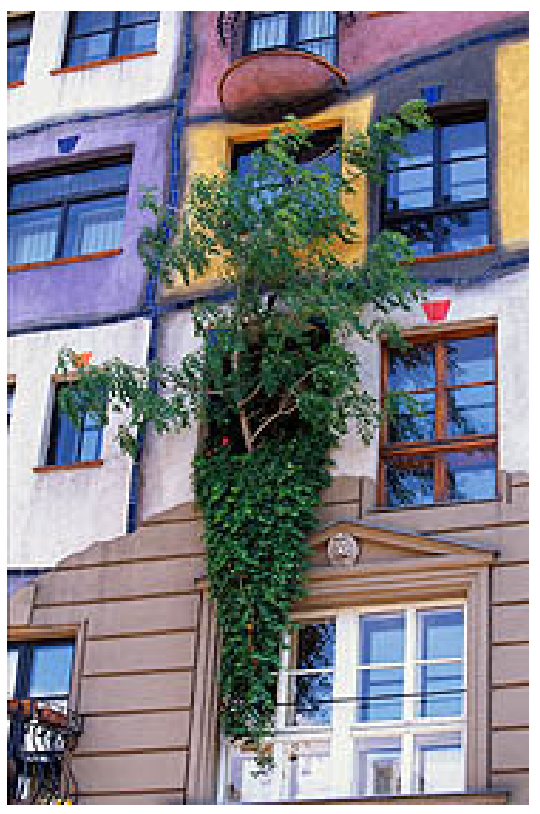

Figura 6 - Mosaico de telhas na Igreja de Santa Bárbara em Bärnbach, 1984-1988. (Fonte:

www.kunsthauswien.com/e nglish/hundertwasser.htm) composta predominantemente de mosaicos, ou por apresentar diversos elementos distintos.

O exemplo de arquitetura de mosaico mais conhecido é a obra de Antoni Gaudí. É inquestionável o valor artístico de sua arquitetura, mas os mosaicos que a compõem só têm esse valor quando observados no espaço da arquitetura.

\section{Outro exemplo é a obra de Friedensreich}

Hundertwasser, que utilizou mosaicos nas paredes, nos pisos e até no telhado, como o fez no telhado da Igreja de Santa Bárbara em Bärnbach, composto por telhas de seis cores diferentes. Hudertwasser também utilizava janelas com tamanhos e cores diferentes, colocadas em alturas diferentes em uma mesma fachada, segundo ele, "para que o observador tenha a impressão de que as janelas estivessem dançando por vontade própria, sem qualquer consideração com os ambientes internos" ${ }^{12}$, compondo um mosaico de janelas, como o da Casa Hundertwasser, em Viena.

\footnotetext{
12 HUNDERTWASSER, Friedensreich. For a more human architecture in harmony with nature - Hundertwasser architecture. Alemanha: Taschen, 1997.
} 

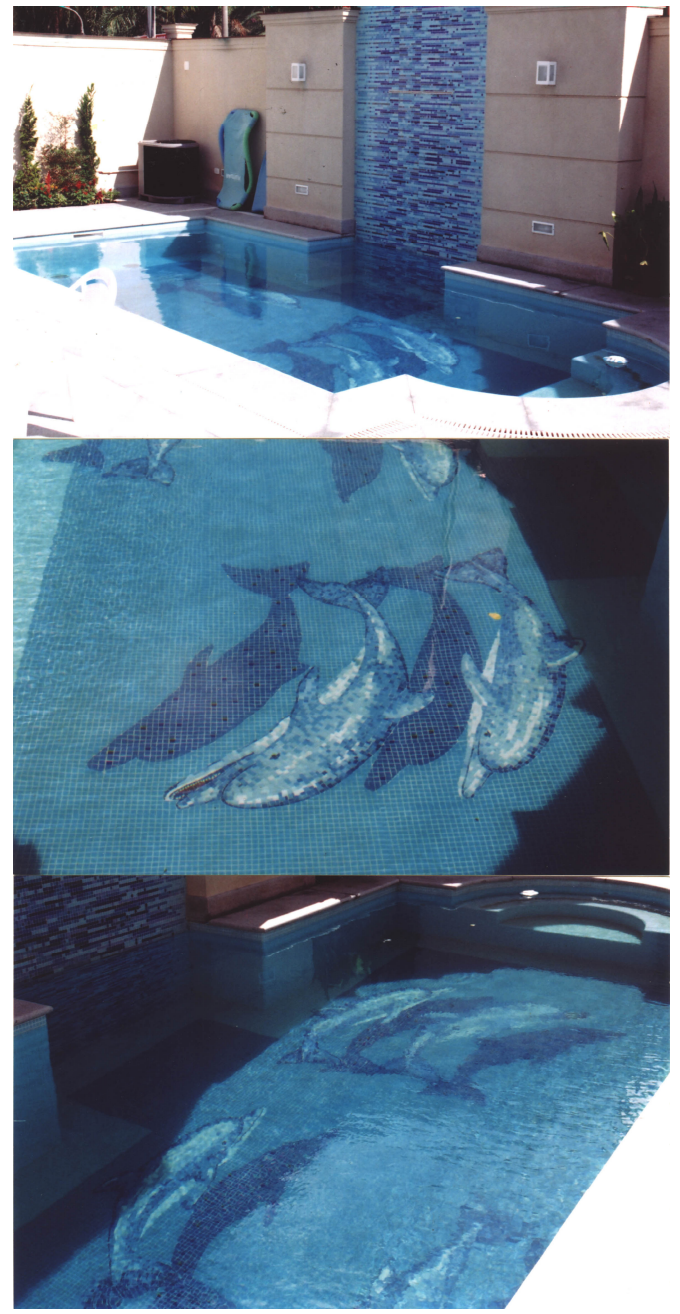

Figura 7 - Mosaico decorativo em piscina com o tema golfinhos. (Fonte: arquivo da Mosaico Objeto de Arte, fotos de Sérgio Secches)
Tanto na obra de Gaudi quanto na de Hundertwasser, os operários também chegaram a participar ativamente na criação de mosaicos; segundo Hundertwasser, o trabalho de assentar ladrilhos um ao lado do outro é um trabalho escravagista.

\subsubsection{Mosaico decorativo na arquitetura}

Assim como o mosaico da arquitetura de mosaicos, o mosaico decorativo na arquitetura, se observado isoladamente, também não tem significado algum, porém, ao contrário do mosaico sendo arquitetura, o mosaico decorativo não é um elemento fundamental, mas um elemento acrescentado à arquitetura com o papel de ornamento. Mas diferentemente dos mosaicos artísticos, os mosaicos decorativos são condicionados ao projeto de arquitetura, o que restringe a criação do mosaicista.

Nesta classificação estão os degradês, barras e desenhos. Este tipo de mosaico é bastante procurado nos ateliês de mosaico principalmente para cozinhas, banheiros e 


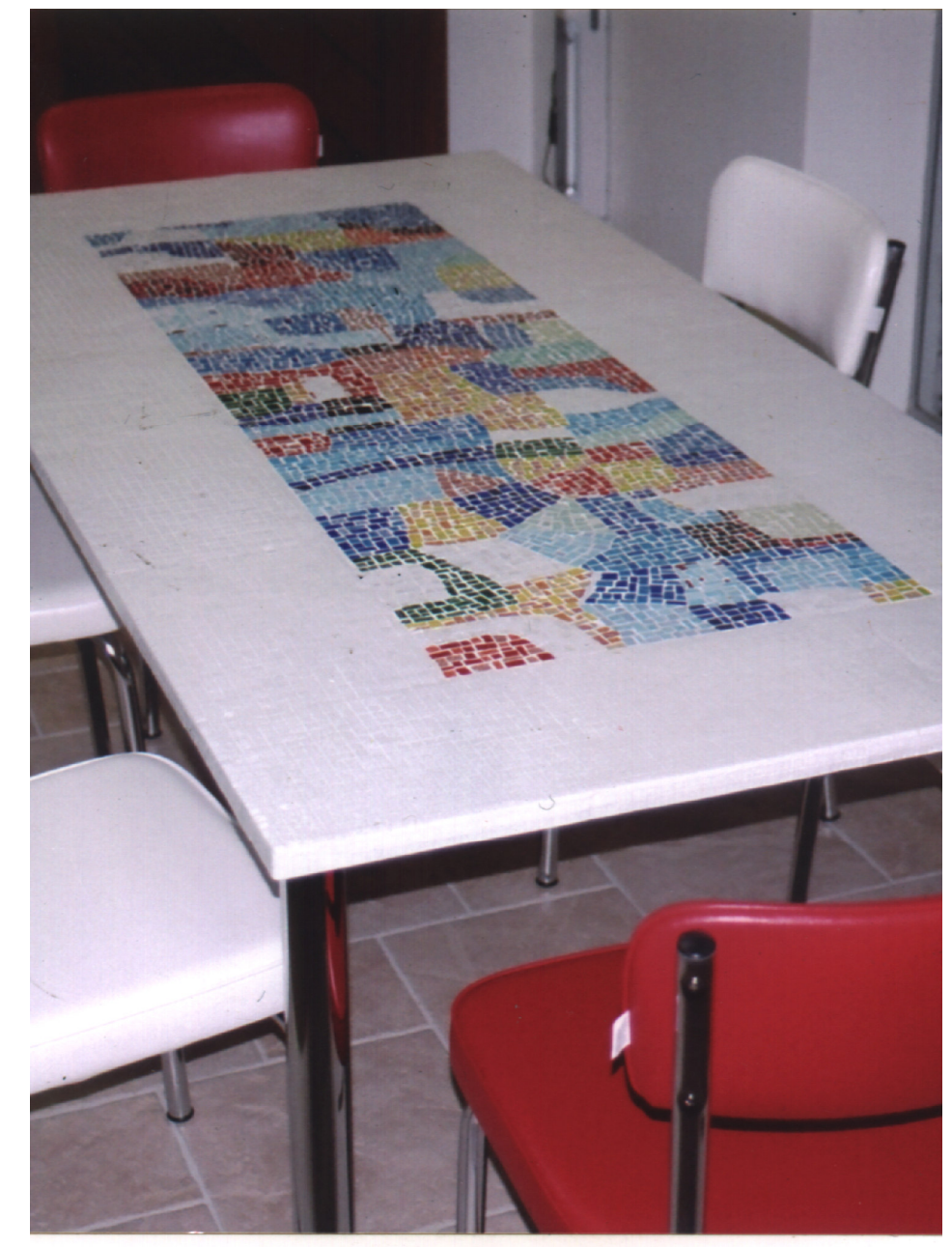

Figura 8 - Mesa com tampo em mosaico. (Fonte: arquivo da Mosaico Objeto de Arte, foto de Sérgio Secches) piscinas. Segundo Sérgio Secches ${ }^{13}$, normalmente, este vem a ser um tipo de trabalho monótono e repetitivo que não permite ao mosaicista usar sua criatividade, visto que, normalmente, o cliente encomenda o mosaico apresentando um determinado desenho e exige que seja idêntico ao desenho apresentado, sem permitir adaptações que poderiam até melhorar o resultado do trabalho; isto normalmente é permitido pelos artistas plásticos.

\subsubsection{Mosaico decorativo em objetos}

Ao falar sobre mosaicos aplicados em objetos, lembram-se aqueles que se encontram em bandejas, portaretratos, caixas, espelhos, tampos de mesa etc. Este tipo de aplicação muitas vezes é visto com maus olhos pelos artistas e arquitetos que trabalham com mosaicos nas aplicações acima discriminadas porque estariam contribuindo para desprestigiar o valor dos mosaicos artísticos e dos mosaicos decorativos de boa qualidade por estarem fortemente inseridos no contexto do "faça você mesmo".

\footnotetext{
${ }^{13}$ Sérgio Secches, mosaicista, em entrevista à autora, ago/2005
} 
As características do material utilizado são um atrativo para os artistas de fim de semana porque o brilho e as cores das tesselas são vistas como suficientes para garantir o bom resultado final do trabalho. Esta constatação pode ser verificada ao observar diversas publicações que estimulam o leigo a executar mosaicos, como nesta citação vista em reportagem de revista de decoração de 1958:

"Tradicionalmente os mosaicos são feitos com pedaços de vidro e pastilhas de cerâmica. Suas cores brilhantes como pedraria, seus dourados e prateados bastam para revelar a alma artística do amador." 14

Também para decoração e vestuário, existe um tipo de mosaico feito com pedaços de tecidos que, juntados a outros, formam um único tecido; este trabalho manual é chamado de

14 "Como tornar-se um mosaicista - Mosaicos que você pode fazer para embelezar o seu lar: Balcão para cozinha, banheiro. Piso de cozinha ou banheiro. Base de lareira. Topo de lareira. Parede de banheiro. Parapeito de janela. Jardineira. Boxe de chuveiro. Parede de lavatório. Jardineira de janela. Moldura para espelho". Casa e Jardim, (42): 62-70, mai. 1958. A reportagem apresenta o passo a passo para o leitor executar seu próprio mosaico. 


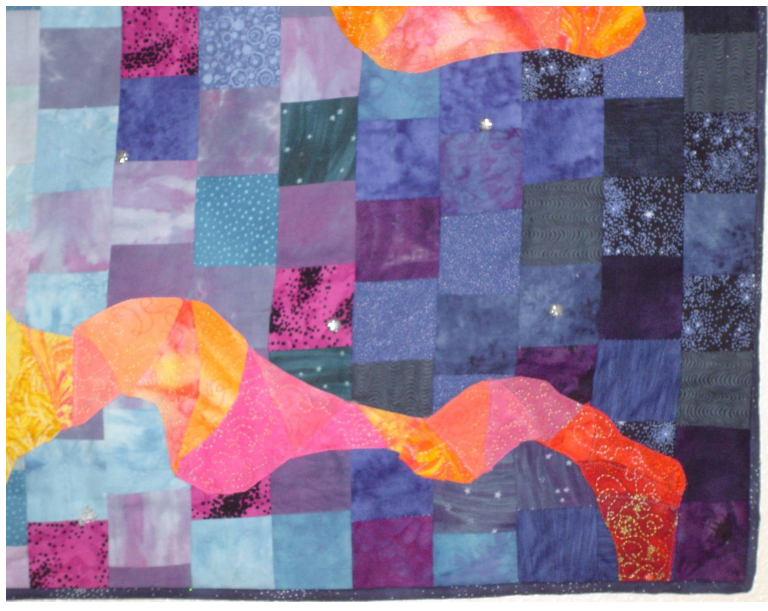

Figura 9 - Patchwork, mosaico feito com pedaços de tecido. (Fonte: www.wikipedia.org/)

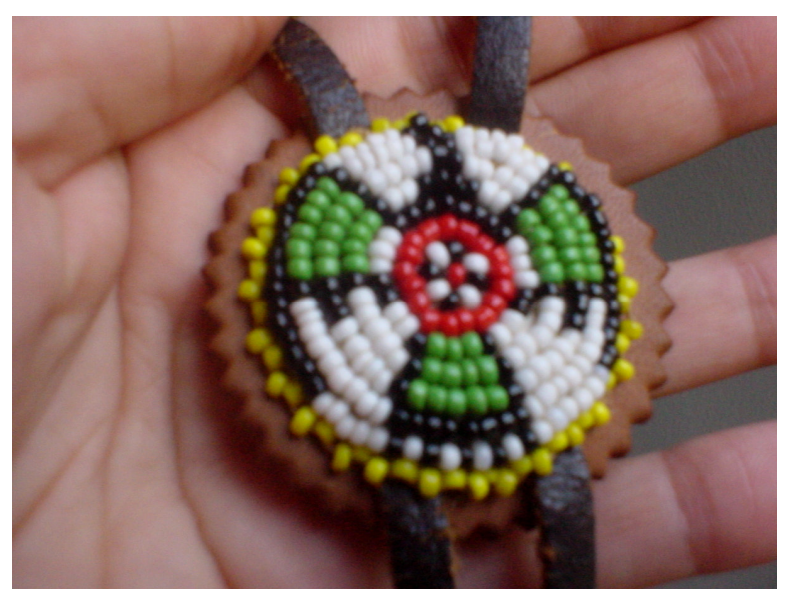

Figura 10 - Mosaico de miçangas feito por índios dos EUA. (Foto da autora) patchwork. Basicamente, existem dois tipos de patchwork, um composto de partes idênticas, com a mesma forma e tamanho, e outro composto de quadrados que são feitos com diferentes desenhos que, unidos, resultam em outras formas. 15

Devemos lembrar que a aplicação de mosaicos em objetos não vem a ser uma exclusividade para objetos nos tempos atuais. Os faraós usavam roupas feiras com técnica similar ao patchwork Os artistas pré-colombianos já aplicavam mosaicos em diversos objetos. Os astecas utilizavam pedras como turquesa e ametista, conchas e madrepérola para revestir máscaras e outros objetos com mosaico. Os índios de todo continente americano, incluindo os brasileiros, também confeccionavam mosaicos utilizando plumas. Ainda hoje, os índios norte-americanos confeccionam mosaicos de miçangas que passam por barbantes, compondo, como bordados, mosaicos que são aplicados principalmente no vestuário.

\footnotetext{
${ }^{15}$ COLTON, Virginia (ed.). Complete guide to needlework. Estados Unidos da América: The Readr's Digest Associaion, 1979.
} 


\subsubsection{Mosaico para comunicação visual}

Ainda que o mosaico esteja aplicado à arquitetura, pode ocorrer de ele estar presente para outro fim que não artístico ou decorativo. Existem algumas diferenças entre arquitetura e programação visual que devem ser consideradas ao analisar um mosaico. Enquanto a arquitetura lida com a articulação do espaço, a programação visual visa estruturar informações, objetivando divulgar mensagens. ${ }^{16}$

Mosaicos podem manifestar-se como design gráfico na escala da arquitetura como logotipos e revestimento usados conforme o padrão de identidade visual de empresas. Apesar de o mosaico ter uma característica de algo durador, estes mosaicos, devido a sua função, assumem um caráter efêmero pelo fato de o comércio constantemente renovar seu mobiliário e seus revestimentos.

O projeto para a rede de lojas O Boticário elaborado pelo arquiteto Manoel Roberto Alves de Lima, em 1998, é um

\footnotetext{
${ }^{16}$ BONSIEPE, Gui. Design: do material ao digital. Florianópolis: FIESC/IEL, 1997. pp. 113-114
} 


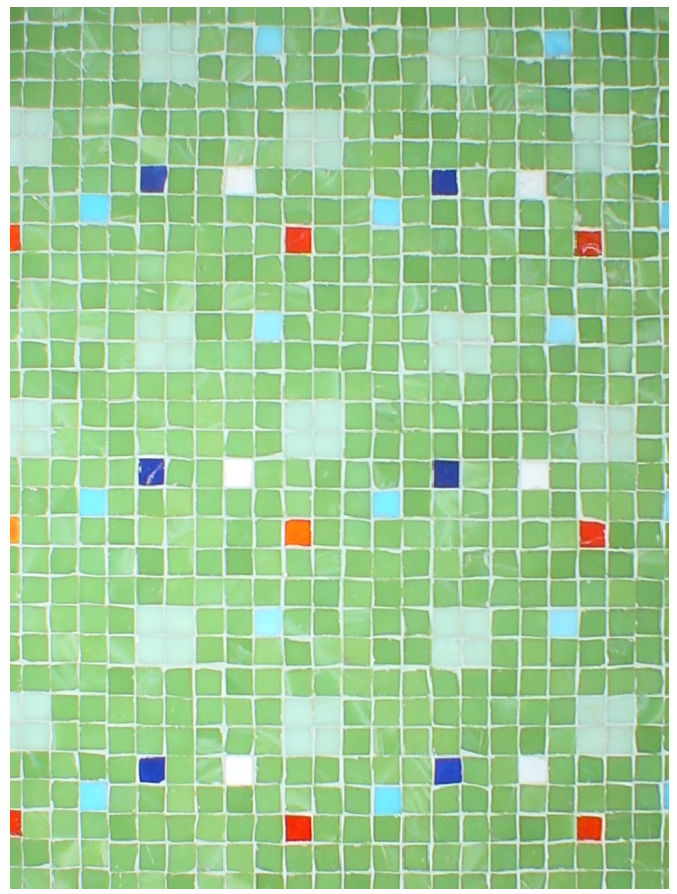

Figura 11 - Mosaico padrão das lojas 0 Boticário. (Foto da autora)

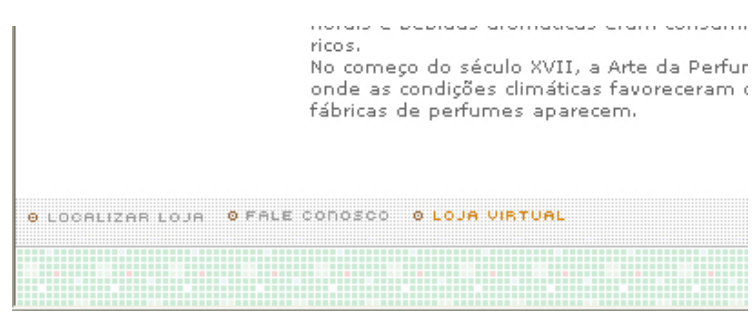

Figura 12 - Detalhe do site do O Boticário. (Fonte: www.boticario.com.br) exemplo deste tipo de aplicação; segundo Lima, a opção pelo revestimento em mosaico de vidro se deu porque o cliente pretendia utilizar materiais que fossem identificados pelos consumidores como nacionais. ${ }^{17}$ Foi criado um padrão de revestimento com o fundo verde e algumas pastilhas brancas, vermelhas, azul-escuros e verde-claros. Esses mosaicos foram aplicados nas paredes externas, nos puxadores das portas e no mobiliário das lojas. Além disso, o desenho do mosaico foi reproduzido em material promocional impresso das lojas e no site da internet.

\subsubsection{Mosaico digital}

As imagens digitais são compostas por pixels (aglutinação de Picture e Element). Um pixel é o menor elemento que pode ser exibido em um dispositivo que exibe imagens, como um monitor.

\footnotetext{
${ }^{17}$ Arquiteto Manoel Roberto Alves de Lima em entrevista à autora, mai/2006.
} 
O tamanho, a forma e as cores do pixe/ variam de acordo com o dispositivo, podendo ou não ser visíveis.

Quando os pixels são visíveis, em geral enxergamos pontos ou quadrados. Por ser o elemento mínimo, cada pixel pode ter apenas uma cor. Em um monitor colorido, cada pixel é composto de três pontos com as cores verde, vermelho e azul. Cada ponto pode exibir 256 tonalidades diferentes dessas cores. Combinadas as diferentes tonalidades nos três pontos, neste dispositivo, o pixel pode ter 16 milhões de cores diferentes. Quanto maior a quantidade de pixels em uma determinada superfície, melhor a resolução da imagem.

Apesar de todas as imagens exibidas nestes dispositivos serem compostas por pequenos elementos, não seria correto classificar todas elas como mosaicos, visto que muitas delas têm como origem desenhos e fotografias que passaram por um processo de digitalização ou apresentam elementos gerados pela própria máquina, o que não é característica do processo de execução de um mosaico.

A pixel art consiste em criar desenhos editados manualmente no computador, pixel por pixel; este é um 
trabalho de paciência e concentração, assim como o modo de trabalho do mosaicista tradicional. Para não descaracterizar este tipo de trabalho manual, os artistas puristas utilizam o mínimo de recursos disponíveis para edição de imagens e condenam o uso de ferramentas que geram pixels automaticamente, como as usadas para criar formas geométricas e texturas.

Acredita-se que o conceito da pixel art teve início na década de 70, aliado à necessidade de criar imagens para dispositivos de exibição de imagens que, na época, tinham baixa resolução ${ }^{18}$. O emprego mais conhecido da pixel art é em video game, onde também é conferido movimento às imagens, mas com o aumento da resolução das imagens e o uso de gráficos tridimensionais, ela perdeu um pouco desse campo.

Em 1996, foi lançado pela fábrica de brinquedos e produtora de animações japonesa Bandai o animal de

\footnotetext{
${ }^{18}$ O termo pixel art só veio a ser empregado pela primeira vez em 1982 por Adele Goldbert e Robert Flegal em uma publicação do Palo Alto Research Center.
} 

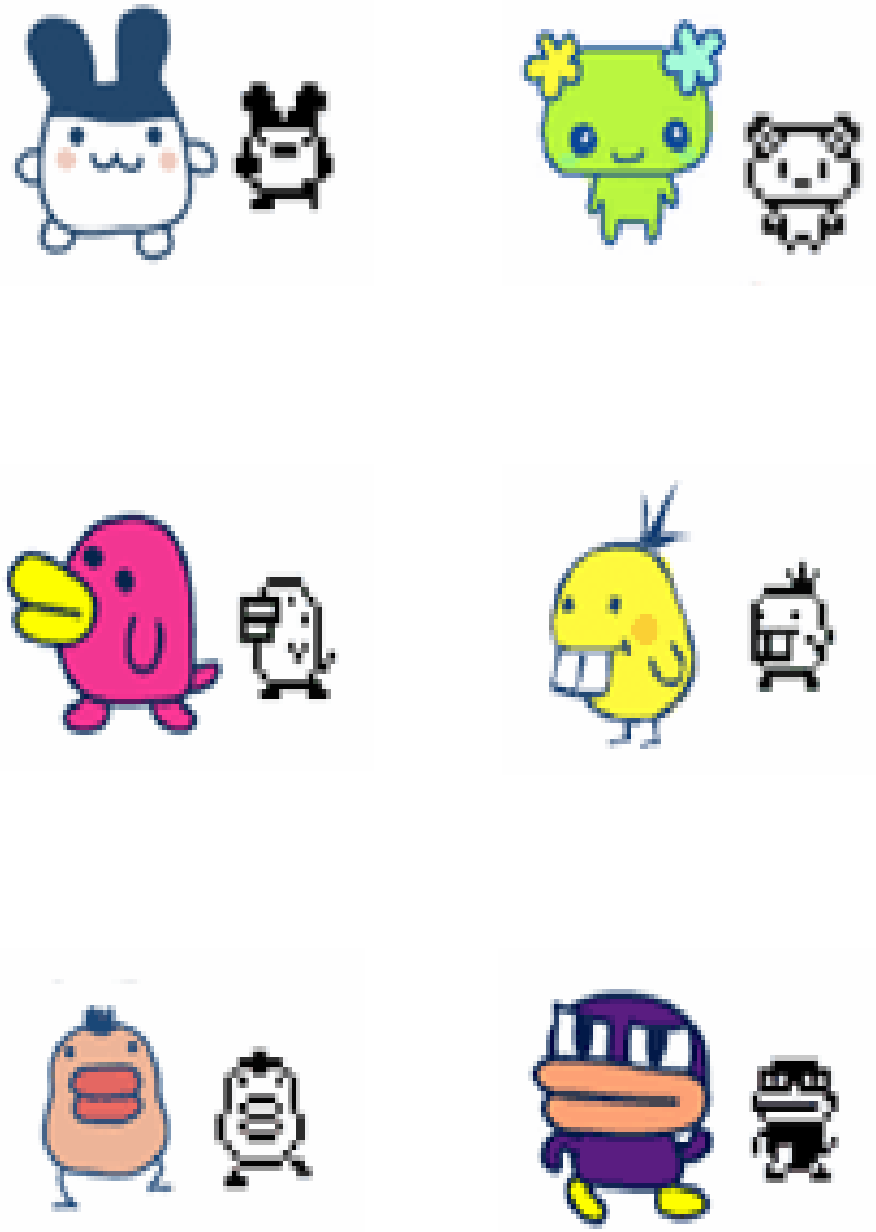

Figura 13 - Personagens Tamagotchi ao lado de suas versões com pixels aparentes. (Fonte: www.tamagotchi.com) estimação virtual Tamagotchi, criado por Aki Maita. Febre nos anos 90, o Tamagotchi vive na tela de um minicomputador em forma de ovo que tem botões para o usuário interagir com o animal, alimentando-o e brincando com ele. Os Tamagotchis foram desenhados com um mínimo de pixels, suficientes para representar cada personagem no minidispositivo.

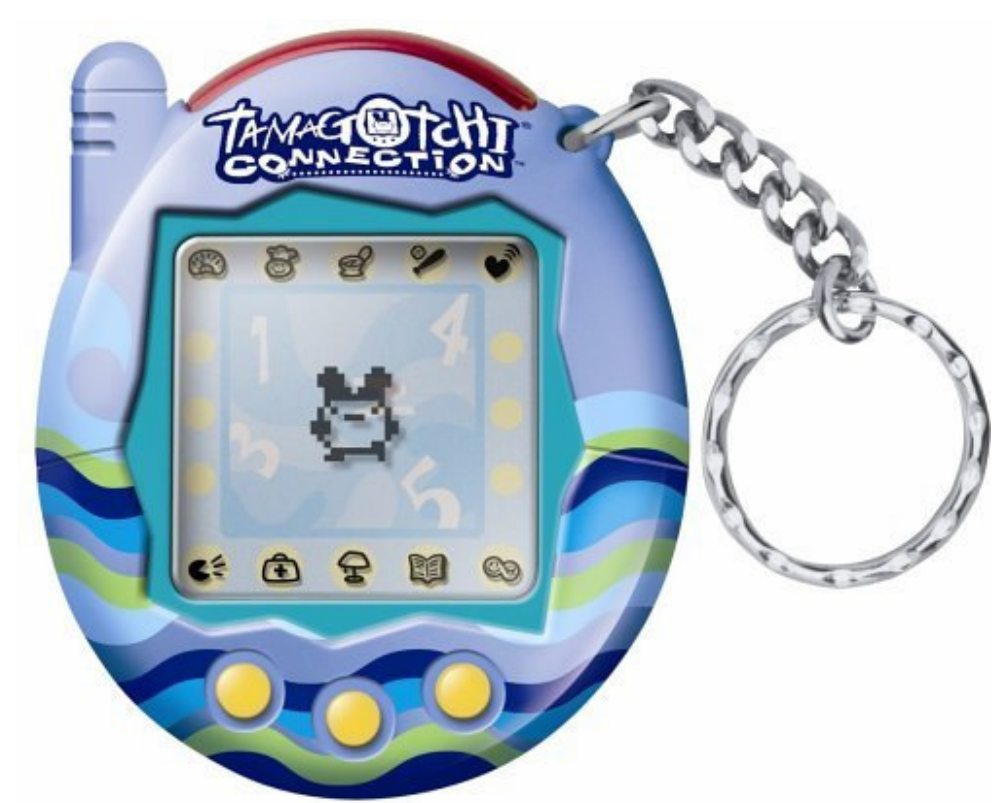

Figura 14 - Animal de estimação virtual Tamagotchi em seu dispositivo. (Fonte: www.tamagotchi.com) 


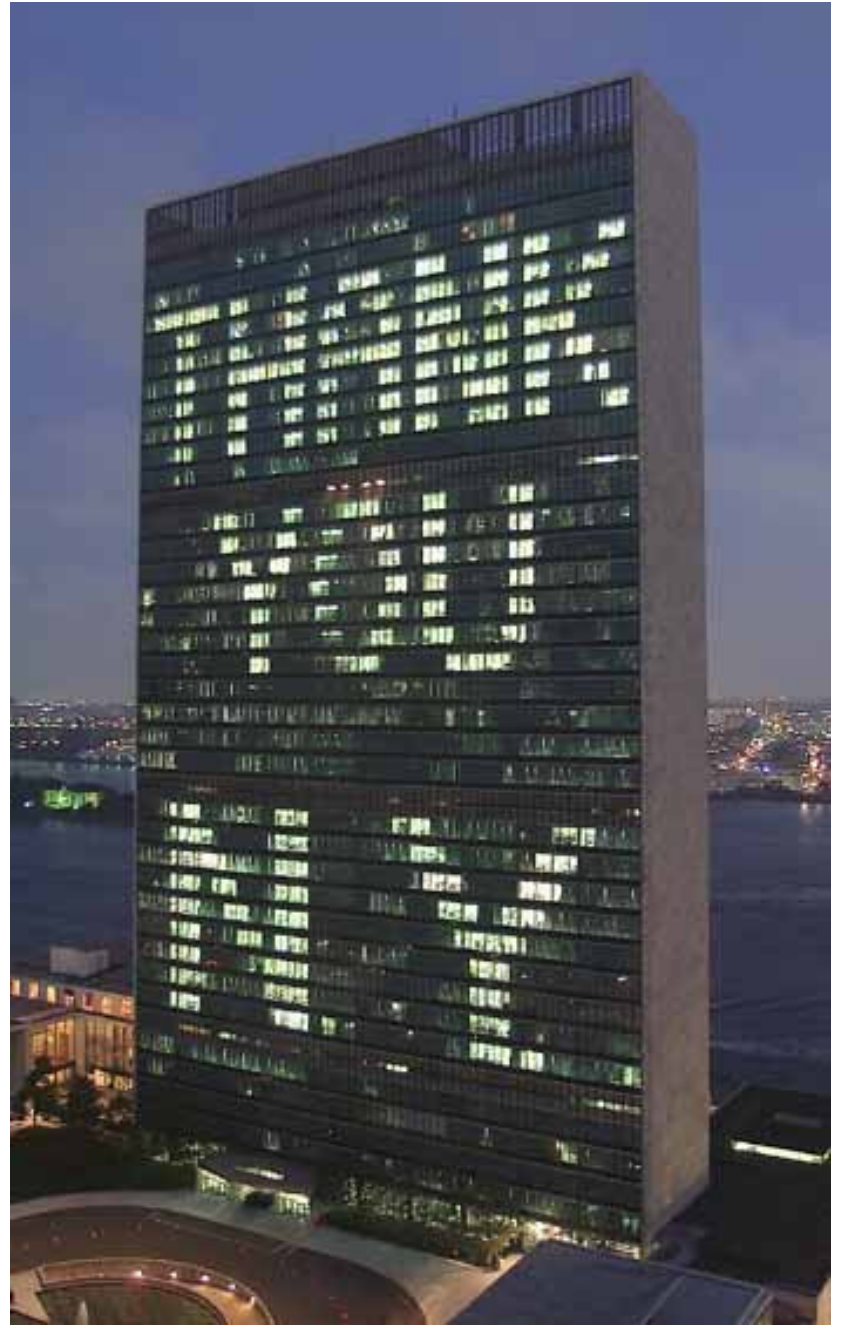

Figura 15 - Mosaico de luzes no edifício sede das Nações Unidas. (Foto de Evan Schneider, fonte: www.un.org)
A pixel arte no presente início do século XXI é bastante encontrada em dispositivos pequenos como telefones celulares, além de contar com vários artistas e apreciadores que divulgam desenhos na internet.

Os dispositivos de exibição da imagem em pixels não se resumem a aparelhos eletrônicos; o dispositivo pode ser a própria arquitetura, como em mosaicos feitos com as luzes das salas de um edifício. Entre outros exemplos, foi exibido, em setembro de 2000 , por este meio, na fachada do edifício das Nações Unidas, um agradecimento à cidade, a Cidade de Nova Iorque, por ter sediado o Millennium Summit, evento das Nacões Unidas que recebeu cerca de 150 chefes de estado.

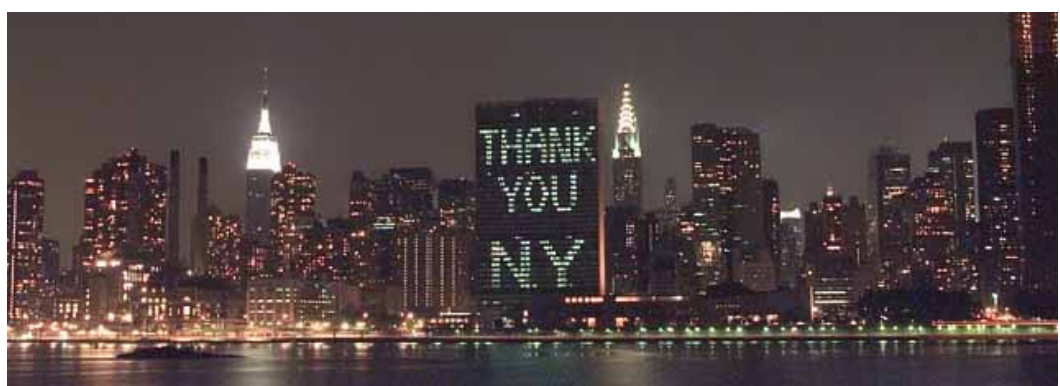

Figura 16 - Vista da cidade de Nova lorque com o mosaico das Nações Unidas. (Foto de Eskinder Debebe, fonte: www.un.org) 


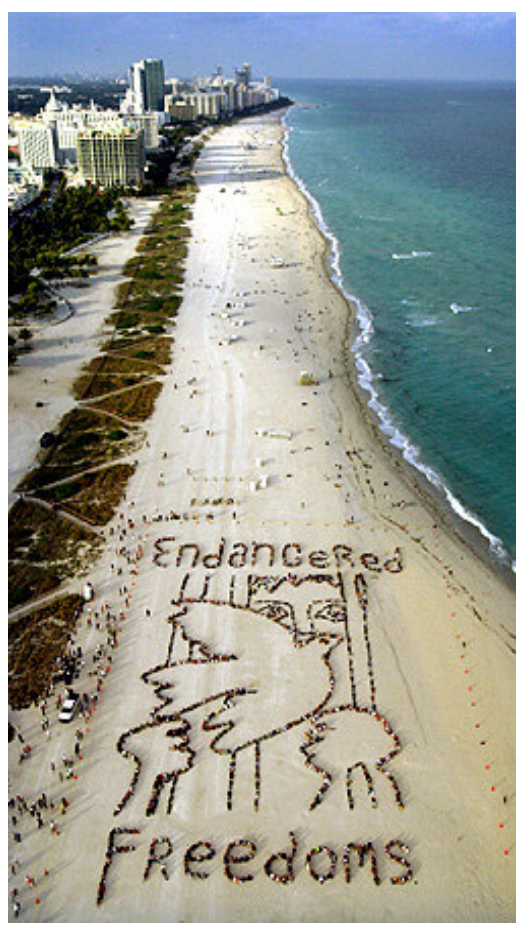

Figura 17 - Mosaico humano de John Quigley em Miami Beach. (Foto de Peter Andrew Bosch, fonte: http://www.scvhistory.com scvhistory/signal/newsmak er/sg020104.htm)

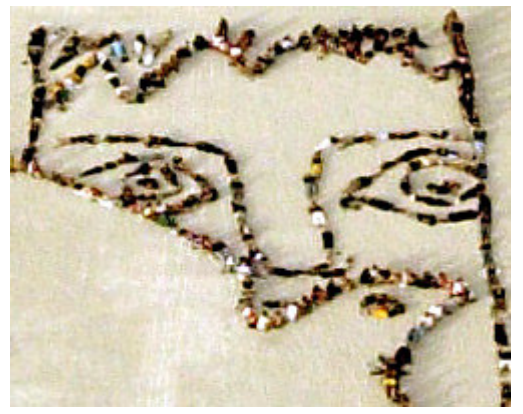

Figura 18 - Detalhe de

mosaico humano. (Foto de Peter Andrew Bosch, fonte: http://www.scvhistory.com/ scvhistory/signal/newsmak er/sg020104.htm)

\subsubsection{Mosaico em performances}

Por definição, performance é uma ação desenvolvida por artistas plásticos que, em geral, resulta em um trabalho documentado através de fotos o vídeos. ${ }^{19}$

Mosaicos humanos que têm como peças os corpos de várias pessoas, ou objetos coloridos que são segurados por pessoas em posições planejadas para formar um desenho, podem ser classificados como tal.

Em 2004, o educador ambiental americano John Quigley organizou um mosaico com cerca de mil pessoas em Miami Beach, a partir de um desenho de Picasso contendo uma mensagem sobre liberdade de expressão e direitos humanos. Quigley já organizou dezenas de mosaicos humanos, todos com a intenção de unir as comunidades para comunicar mensagens importantes para o bem comum.

\footnotetext{
19 MORAIS, Frederico. Panorama das Artes Plásticas, séculos XIX e XX. São Paulo: Instituto Cultural Itaú, 1991. p. 159.
} 
Mosaicos em performances também são comuns em eventos esportivos, onde várias pessoas manipulam placas coloridas na arquibancada formando desenhos. Assim como o mosaico digital, o mosaico humano também permite animações, podendo ser combinado com dança. 


\title{
2. Fazer mosaicos
}

\author{
Drls? Faço meu amor em vidrotil \\ nossos coitos são de modernfold \\ até que a lança de interflex \\ vipax nos separe \\ em clavilux \\ camabel camabel o vale ecoa \\ sobre o vazio de ondalit \\ a noite asfáltica \\ plkx
}

- Carlos Drummond de Andrade

\subsection{Métodos de colocação}

Os métodos de colocação são relacionados ao lugar onde se dá a execução do mosaico, diretamente no local onde ficará definitivamente, ou sobre uma superfície provisória para, depois, ser colocado sobre a definitiva. Os métodos de colocação são o direto e o indireto. 


\subsubsection{Colocação direta}

As peças do mosaico são colocadas diretamente sobre o suporte definitivo que já se encontra com argamassa ou cola, sendo posteriormente aplicado o rejunte. Este método é o mais simples de todos, porém não permite que as tesselas já aderidas sejam mudadas de lugar com facilidade. Para a colocação direta, é recomendado o uso de argamassa com secagem lenta.

\subsubsection{Colocação indireta}

O mosaico é montado sobre uma superfície provisória e posteriormente aplicado à superfície definitiva. O mosaico chega à superfície definitiva colado em papel; as placas de papel com os pedaços do mosaico são colocadas sobre a argamassa e, depois que a argamassa está suficientemente seca, o papel é descolado da superfície com água e feito o rejunte. 
Existem dois modos para preparar um mosaico para a colocação indireta:

- O primeiro consiste em executar o mosaico sobre uma superfície onde as tesselas não sejam aderidas, permitindo que o trabalho seja feito em mais tempo e que possam ser feitas alterações até que a composição esteja pronta. Ao final todas as peças são coladas a um papel colocado sobre o trabalho pronto;

- O segundo consiste em montar o mosaico colando as tesselas com a face que deverá ficar aparente diretamente sobre o papel; para executar esse tipo de mosaico é preciso usar peças que tenham a mesma cor na frente e no verso, que vem a ser o caso das pastilhas de vidro, para permitir a visualização e também é preciso montar o mosaico invertido, como um espelho, para que seja aplicado na posição correta. 


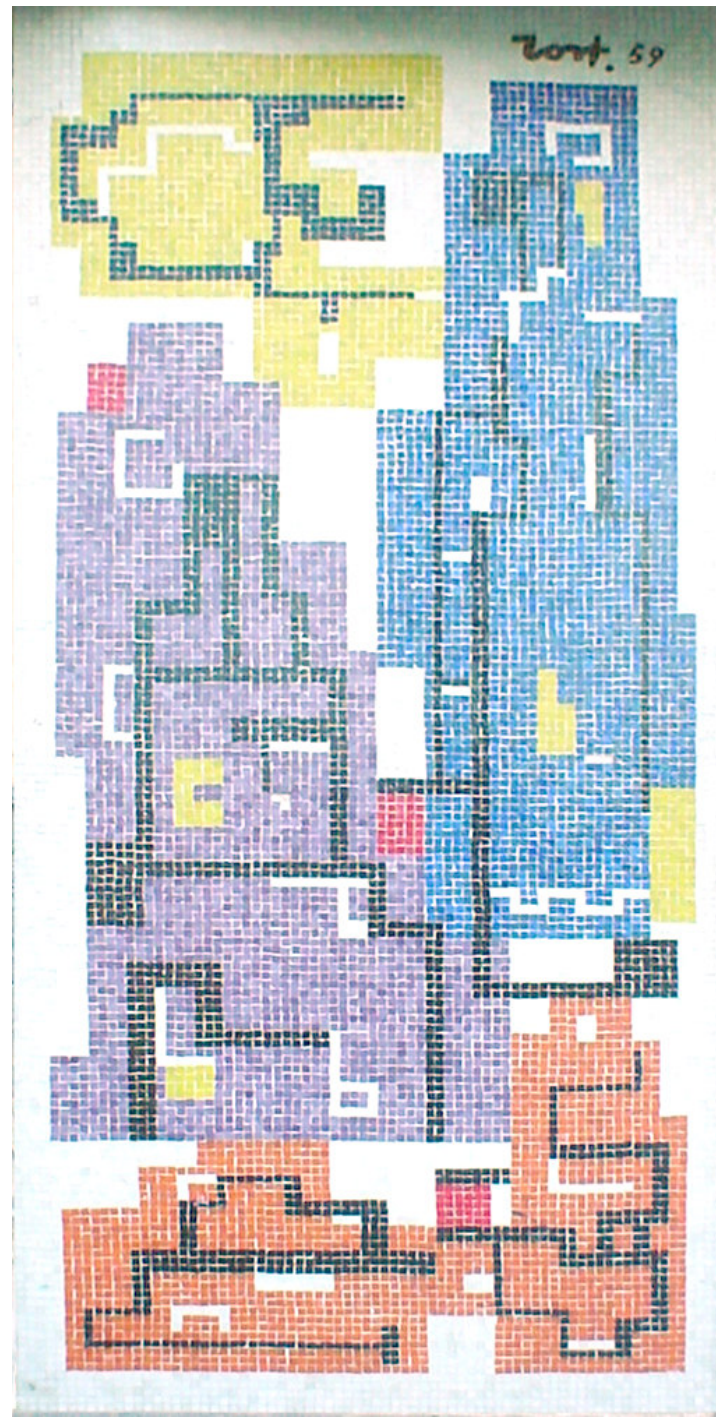

\subsection{Sistemas de colocação}

Os sistemas de colocação se referem ao modo em que as peças dos mosaicos são dispostas, o tipo de corte e a posição. Os três sistemas listados a seguir são os básicos que podem ser identificados em qualquer mosaico.

Os sistemas estão exemplificados com mosaicos que apresentam apenas o respectivo sistema de colocação mencionado. Porém, é muito comum um mesmo mosaico apresentar mais de um sistema de colocação, principalmente para diferenciar a figura e o fundo.

\subsubsection{Opus tesselatum - obra tesselada}

Utilizam-se tesselas quadradas, uniformes, do mesmo tamanho, e com cores diferentes. Este sistema é bastante

Figura 19 . Mosaico do

Edifício Verona. (Foto da autora) utilizado em composições de motivos geométricos, visto que a forma da disposição das tesselas acompanha a forma das próprias tesselas. Por ser simples e por dispensar o corte das 


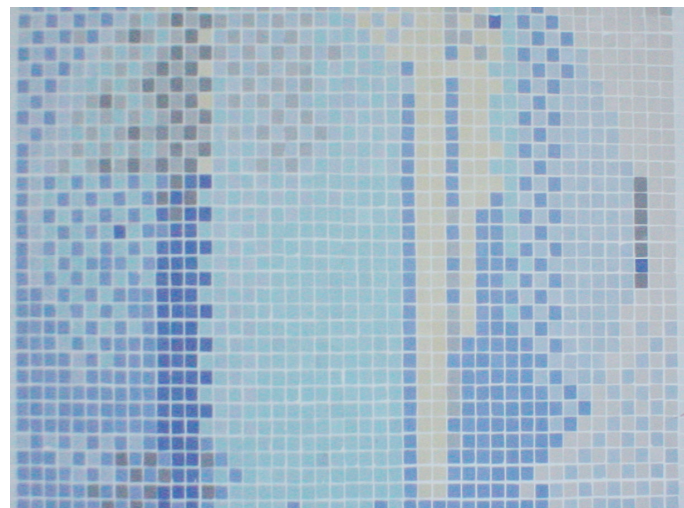

Figura 20 - Detalhe do mosaico do Edifício Santa Rosa de Lima. (Foto da autora)

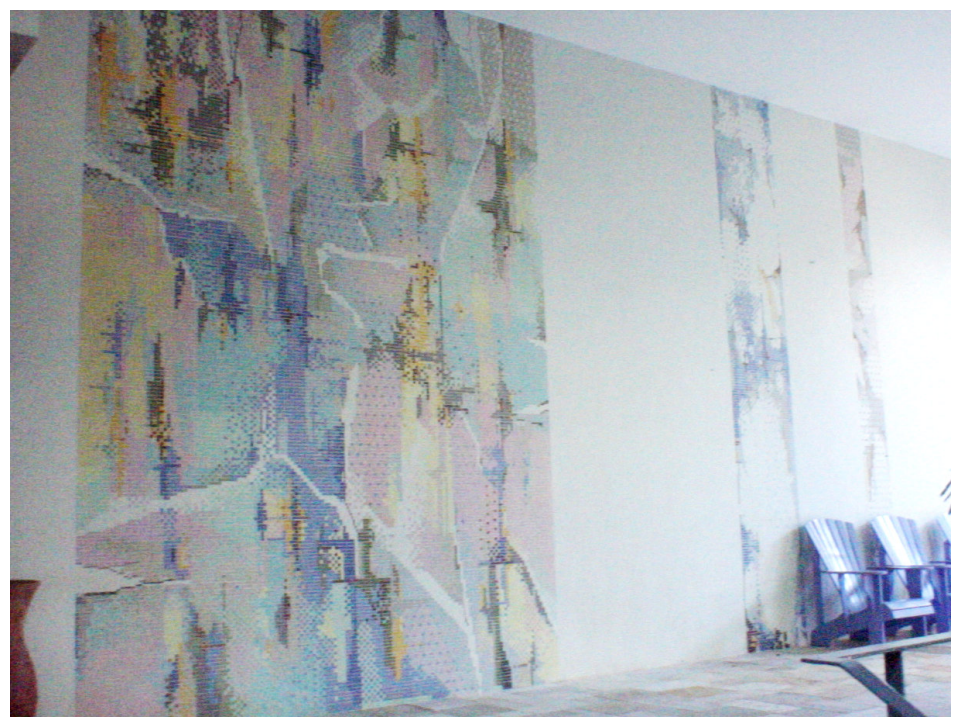

Figura 21 - Mosaico de pastilha cerâmica do Edifício Santa Rosa de Lima, de Heinz Kuhn. (Foto da autora) pastilhas, este sistema implica uma demanda menor de tempo para a execução.

\section{O mosaico do Edifício Verona ${ }^{20}$ é um bom exemplo} para ilustrar uma obra tesselada porque podemos observar facilmente que o desenho, bastante rígido, está condicionado à malha regular que, por sua vez, está condicionada à forma das pastilhas. Neste mosaico, o quadrado se impõe permitindo apenas a representação de formas derivadas da repetição do quadrado dentro de uma malha regular.

Um mosaico com esta mesma configuração também pode, de perto, exibir essa mesma rigidez e, de longe, mostrar traços em diagonais, curvos e com formas livres. Nestes casos as pastilhas aparecem do mesmo modo que os pixels ao serem vistos em uma imagem digitalizada. $O$ mosaico de Heinz Kuhn no Edifício Santa Rosa de Lima ${ }^{21}$,

\footnotetext{
${ }^{20}$ Mosaico de pastilha de vidro de 1,5×3,6m (aprox.), de autor desconhecido, de 1959, implantado no Edifício Verona, Rua Tenente Otávio Gomes, 22, São Paulo, SP, em parede externa na esquina com a Rua Tamandaré.

${ }^{21}$ Mosaico de pastilha cerâmica em dois painéis de 4,6x8,4m e 4,6x10,9m, de 1962, implantado no Edifício Santa Rosa de Lima, Rua Aureliano Coutinho, 382, São Paulo, SP, na parede do pavimento terreo.
} 
visto de longe, é uma composição solta e tem essa característica.

\subsubsection{Opus vermiculatum - obra vermiculada}

As tesselas, que antes eram quadrados perfeitos, são cortadas em formas irregulares, e dispostas de forma irregular, fazendo curvas, como minhoca.

"A experiência pessoal nos demonstra que tais irregularidades não causam, de maneira alguma, um efeito ruim; ao contrário, aumentam a naturalidade, estimulam nosso interesse e, sobretudo, reforçam o caráter pinturesco do conjunto."

A afirmação acima é de Camillo Sitte, ao falar sobre a irregularidade das praças antigas ${ }^{22}$, porém, também pode ser aplicada ao mosaico com tesselas irregulares.

\footnotetext{
22 SITTE, Camillo. A construção das cidades segundo seus princípios artísticos. São Paulo: Editora Ática, 1992. p. 63.
} 


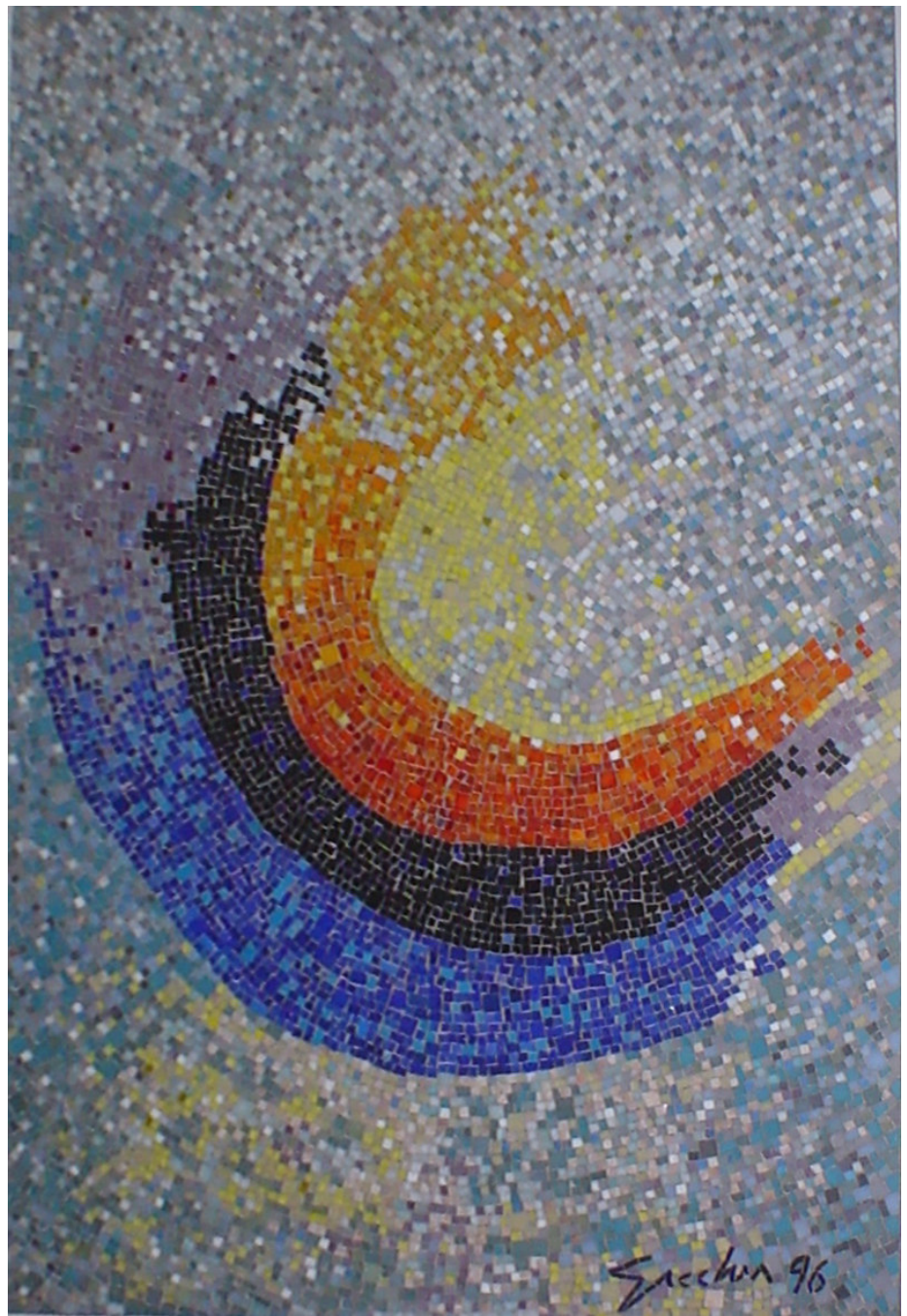

Figura 22 - Painel em mosaico de pastilha de vidro de Sérgio Secches. (Foto da autora)
Sitte acrescenta que, em muitos casos, para os olhos do observador menos atento, uma praça com uma forma irregular é um quadrado ou retângulo perfeito. O mesmo ocorre com os mosaicos. Ao olharmos o painel do mosaicista Sérgio Secches, em um primeiro momento, parece que a composição é feita com diversos quadrados, mas este painel foi executado com todas as pastilhas que ao sair da fábrica eram quadradas, cortadas manualmente uma a uma, para formar um mosaico com uma curva tão natural quanto uma pincelada sobre uma tela.

As tesselas são cortadas em formas irregulares que viabilizam a execução de composições figurativas mais detalhadas e precisas. Alguns autores enfatizam que este tipo de mosaico é feito com peças pequenas, porém a questão do tamanho das peças não deve ser relacionada à escala de medida, mas a distância em que se encontra o observador. 


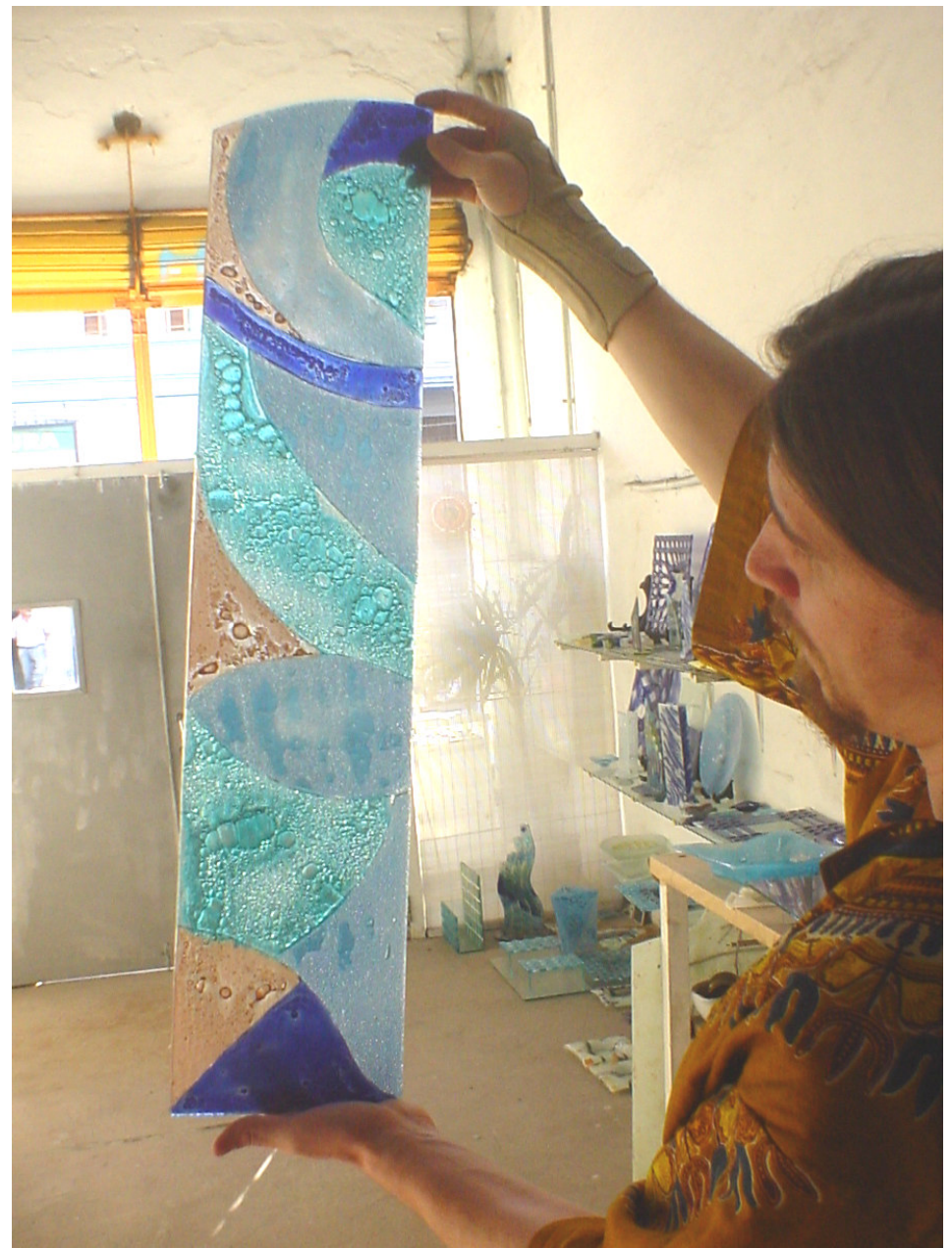

Figura 23 - Peça em mosaico de lâminas de vidro fundidas de Gustavo Benini. (Foto da autora)

\subsubsection{Opus sectile - obra marchetada}

Também conhecido como mosaico florentino, as peças que compõem o mosaico, na maior parte das vezes, placas de pedra, como mármores e granitos de cores variadas, são cortadas de uma maneira que resulta em um trabalho do tipo marchetado.

Este não é um sistema que pode ser utilizado na execução de um mosaico de pastilhas, porém pode ser executado com chapas de vidro cortadas de modo a formar um desenho, as quais, depois, são coloridas e coladas através da técnica fusing, que é utilizada para fundir chapas de vidro em altas temperaturas. Esta técnica também permite colorir o vidro utilizando corantes com propriedades químicas parecidas com as do vidro e usar fôrmas para transformar as chapas em outros objetos. ${ }^{23}$

\footnotetext{
${ }^{23}$ Gustavo Benini, vidreiro, em depoimento à autora, set/2006.
} 


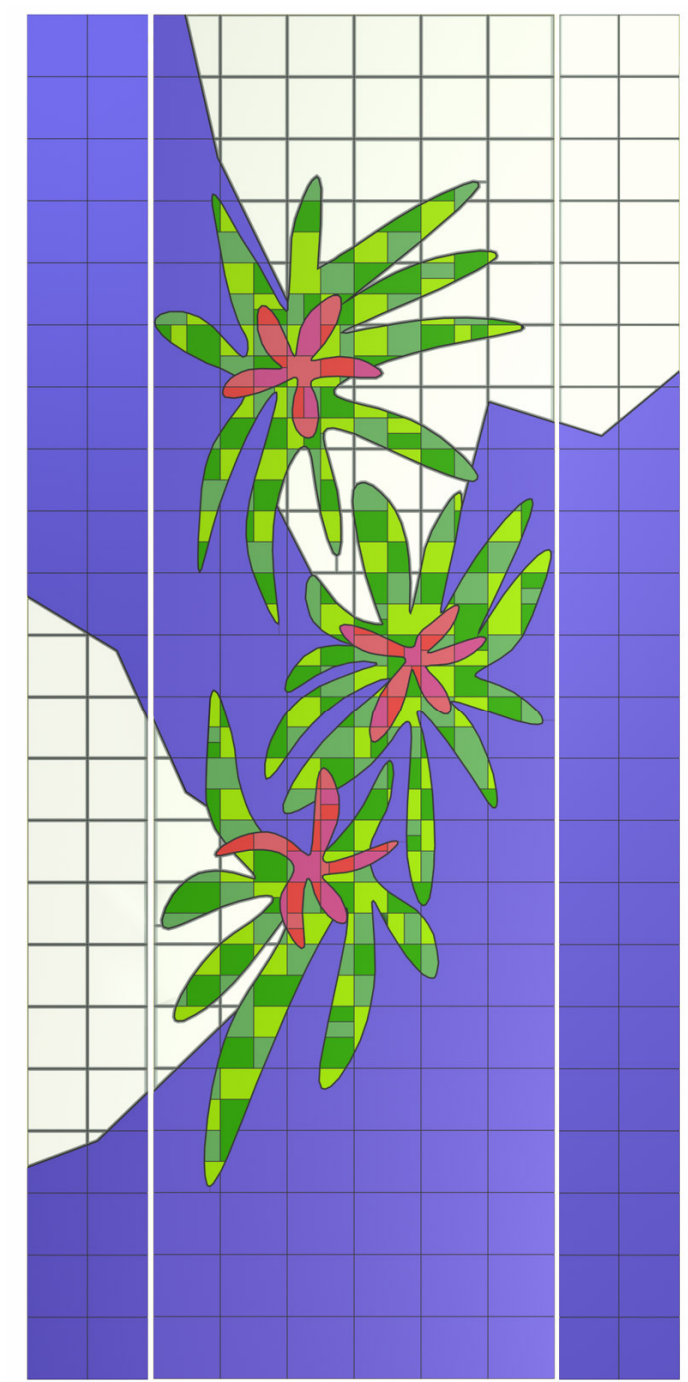

\subsection{Execução do painel}

\subsubsection{Projeto}

Em um projeto de mural é fundamental pensar no lugar onde ele é implantado. Para manter o foco apenas no mosaico, nesta primeira experiência, foi evitada a interatividade da arquitetura com o mosaico. A opção foi por um painel sem moldura, um mosaico avulso, uma obra autônoma.

Os critérios para o projeto foram a viabilidade de execução e a inclusão de elementos que poderiam ser valorizados em um mosaico. Houve também uma busca por leveza e simplicidade.

Figura 24 Projeto do mosaico

Bromélias.

(Fonte: arquivo pessoal)
Uma idéia foi executar em escala menor o mosaico Bromélias. Bromélias é um projeto para um mural em mosaico de vidro de $600 \mathrm{~m}^{2}$, que a autora fez em 2002 para o 
concurso Prêmio Quota de Arte $^{24}$, o qual foi planejado para ocupar toda a fachada de um edifício comercial.

Ele foi projetado para ser uma obra marchetada. $\mathrm{Na}$ proposta original, lâminas de vidro que seriam aplicadas sobre uma caixilharia, as quais seriam recortadas em tamanhos grandes que chegariam até dois metros.

Nesta composição, as cores foram privilegiadas, elas são poucas, oito, e estão dispostas em espaços bem determinados, sem misturas. Se executado em pastilhas de vidro, o mosaico resultante teria vários planos monocromáticos.

Como originalmente foi proposto como uma obra marchetada com $600 \mathrm{~m}^{2}$, o projeto precisaria ser adaptado para as mudanças de material e de tamanho. Adaptações como essas são comuns, principalmente quando um mosaico

\footnotetext{
${ }^{24}$ Concurso para a escolha do mosaico no Edifício Exclusive, na Avenida Angélica, 2016; os jurados Enock Sacramento, Fábio Magalhães e Jacob Klintovitz selecionaram o projeto apresentado como um dos finalistas do concurso. Atualmente, no endereço citado, encontra-se o mosaico em pastilhas de vidro premiado de Cláudio Tozzi.
} 
reproduz uma pintura ou uma fotografia. Porém, outro fator determinou a opção por não executar uma adaptação deste projeto. Este projeto foi feito para um espaço determinado, tendo uma proposta para aquele espaço. Se ele fosse apresentado em um painel, a mensagem que ele comunica seria perdida.

Abandonada a idéia de executar um projeto de mosaico já existente, a autora passou a procurar um desafio. Era estimulante pensar em uma idéia que não fosse óbvia para um mosaico. Um bom desafio seria o de fazer uso de linhas curvas utilizando o material reto. Representar simbolicamente, através da curva, a natureza fazendo uso de um material industrializado com forma quadrada.

Segundo Gaudí, as linhas retas pertencem ao homem e as linhas curvas pertencem a Deus. De forma mais radical, Hundertwasser dizia que a linha reta é a ferramenta do diabo. Lembrando que a curva é formada pelos pontos de retas que a tangenciam, cada ponto da curva também pertence ao homem (ou ao diabo). Podemos interpretar cada peça de um 


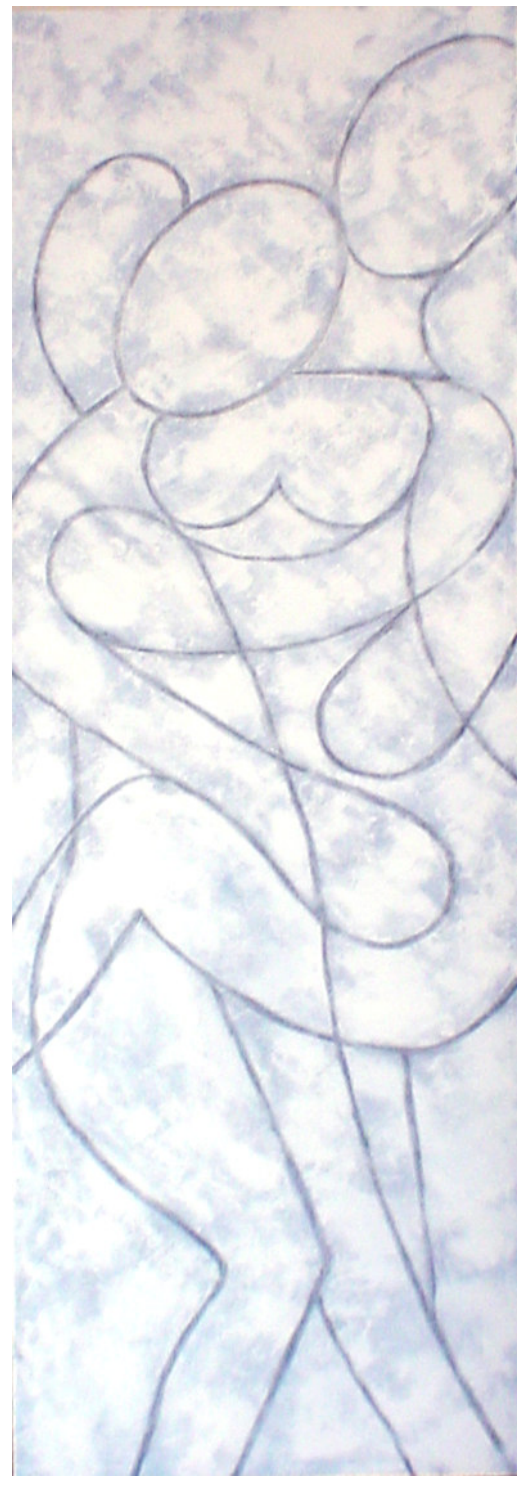

mosaico como sendo um desses pontos, por isso procuramos dispor as pastilhas de modo a tangenciar as curvas.

O projeto do mosaico partiria de um painel, Fondling, que a autora havia executado em acrílico com essas características e com um tema que valoriza essas curvas.

Executar este trabalho em mosaico seria interessante, porém houve uma dificuldade pelo fato de que esta proposta, apesar de simples, poderia implicar em uma execução difícil. A pouca variedade de cor exigiria um estudo mais aprofundado e, talvez, até mais habilidade. Na pintura a autora havia resolvido essa questão, criando uma textura, mas não conseguiu resolver como se faria isso em mosaico. Levando em conta esta dificuldade, este projeto foi adiado, dando lugar a uma outra proposta contendo uma maior variedade de cores.

A solução foi pintar outro painel, desta vez já visando a adaptação para um projeto de mosaico. Assim como Fondling, Laços foi feito usando a técnica de pintura em tela.

Figura 25 - Fondling, A.S.T. $180 \times 60 \mathrm{~cm}$, 2005. (Foto da autora)
Mas, desta vez já haviam sido avaliados os prós e os contras do projeto anterior, o que levou às seguintes diretrizes: 


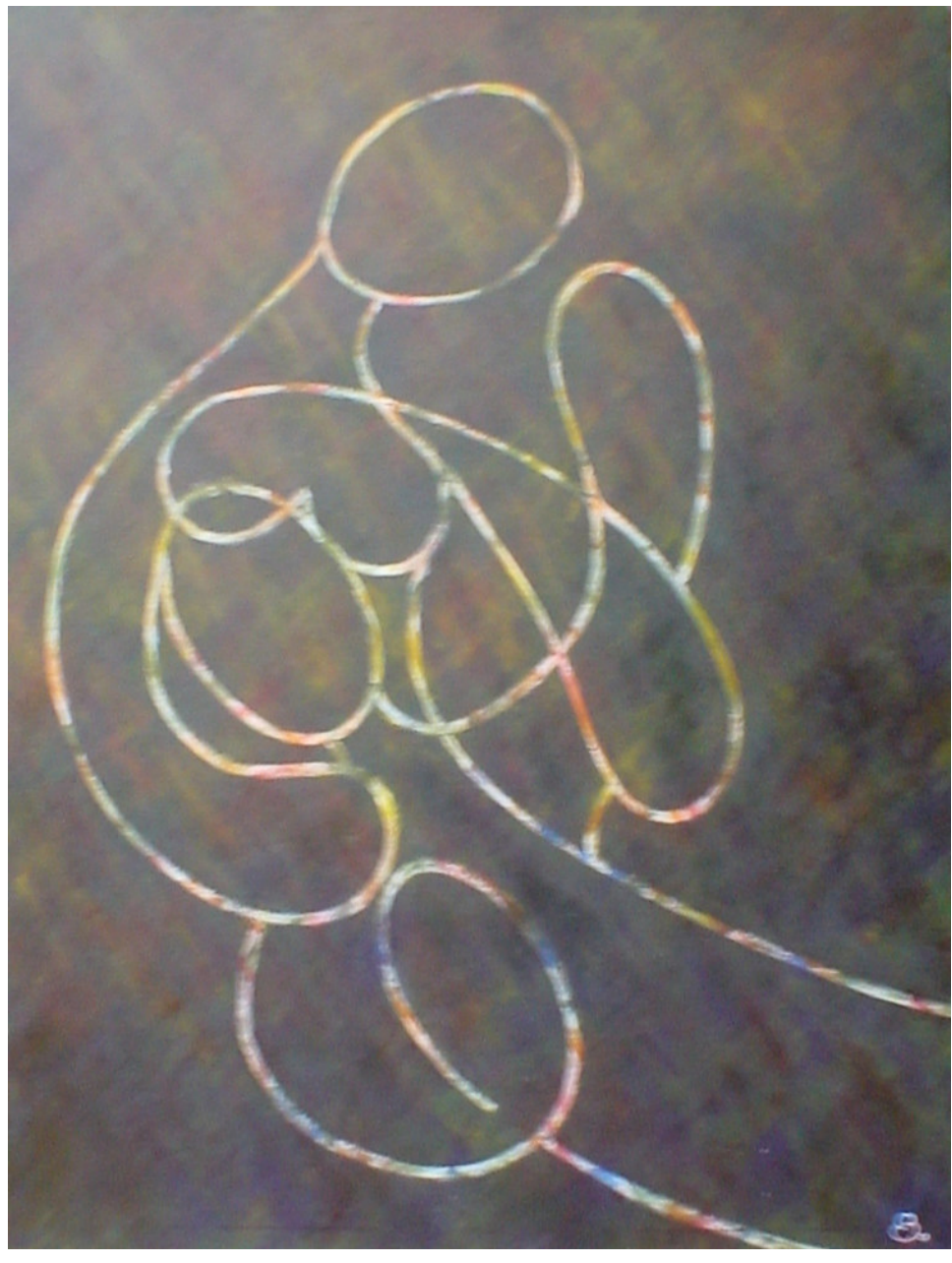

Figura 26 - Laços, A.S.T. $100 \times 80 \mathrm{~cm}, 2006$. (Foto da autora)
- O tema e a utilização da linha curva permaneceriam iguais;

- Muitas cores seriam utilizadas;

- O projeto incluiria um degradê, elemento que pode ser explorado em mosaicos.

Este trabalho foi executado de forma semelhante ao Fondling, desta vez com o fundo verde e as linhas brancas. As outras cores foram introduzidas sobrepostas a todo 0 desenho, tendo cores mais claras no alto que foram sendo substituídas por outras mais escuras no caminho da parte mais baixa.

\subsubsection{Preparação do cartão}

O cartão é o desenho em tamanho real a partir o qual é montado o mosaico. ${ }^{25} \mathrm{O}$ cartão de Laços foi feito de uma fotografia do painel original. A partir da fotografia foi feita uma fotocópia ampliada para as dimensões desejadas. Para

\footnotetext{
${ }^{25}$ CHAVARRIA, Joaquim. O Mosaico. Lisboa: Editorial Estampa, 1998. p. 157
} 


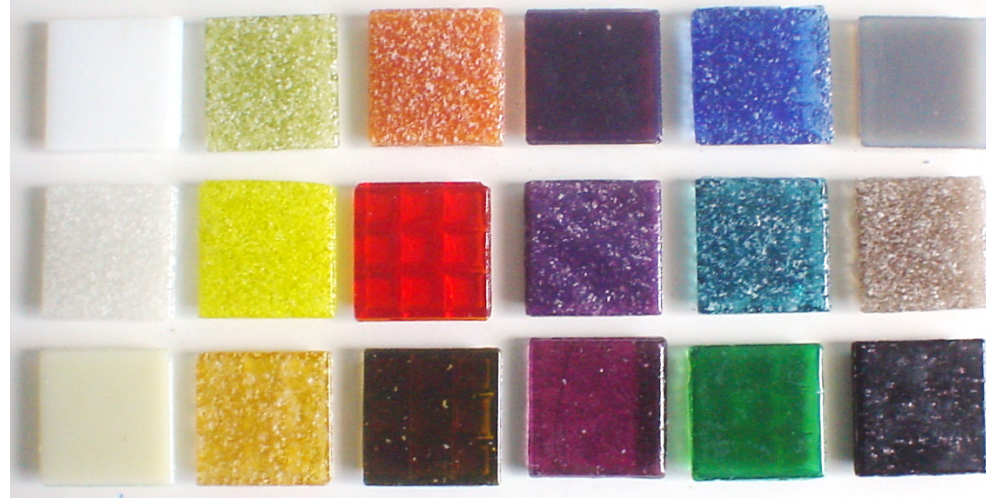

Figura 27 - Pastilhas utilizadas na composição do mosaico Laços. (Foto da autora) permitir a visualização dos dois, lado a lado, a opção foi por executar o mosaico com as mesmas dimensões do trabalho original.

Durante o processo, o cartão sofreu uma pequena distorção em comparação ao painel original, passando de $100 \times 80 \mathrm{~cm}$ para $105 \times 80 \mathrm{~cm}$. O fato de ter proposto um mosaico fora de um contexto de espaço permitiu executá-lo neste formato.

\subsubsection{Estudo cromático}

Foi feita a opção de utilizar cores próximas às da obra original. Diversas pastilhas foram colocadas sobre a fotografia de Laços para observar quais eram as cores mais próximas. Foram escolhidas 18 cores a serem utilizadas repetidas vezes, mas durante o trabalho, conforme a conveniência, seria acrescentado o uso de outras cores. Entre todas, a mais utilizada foi a verde. 


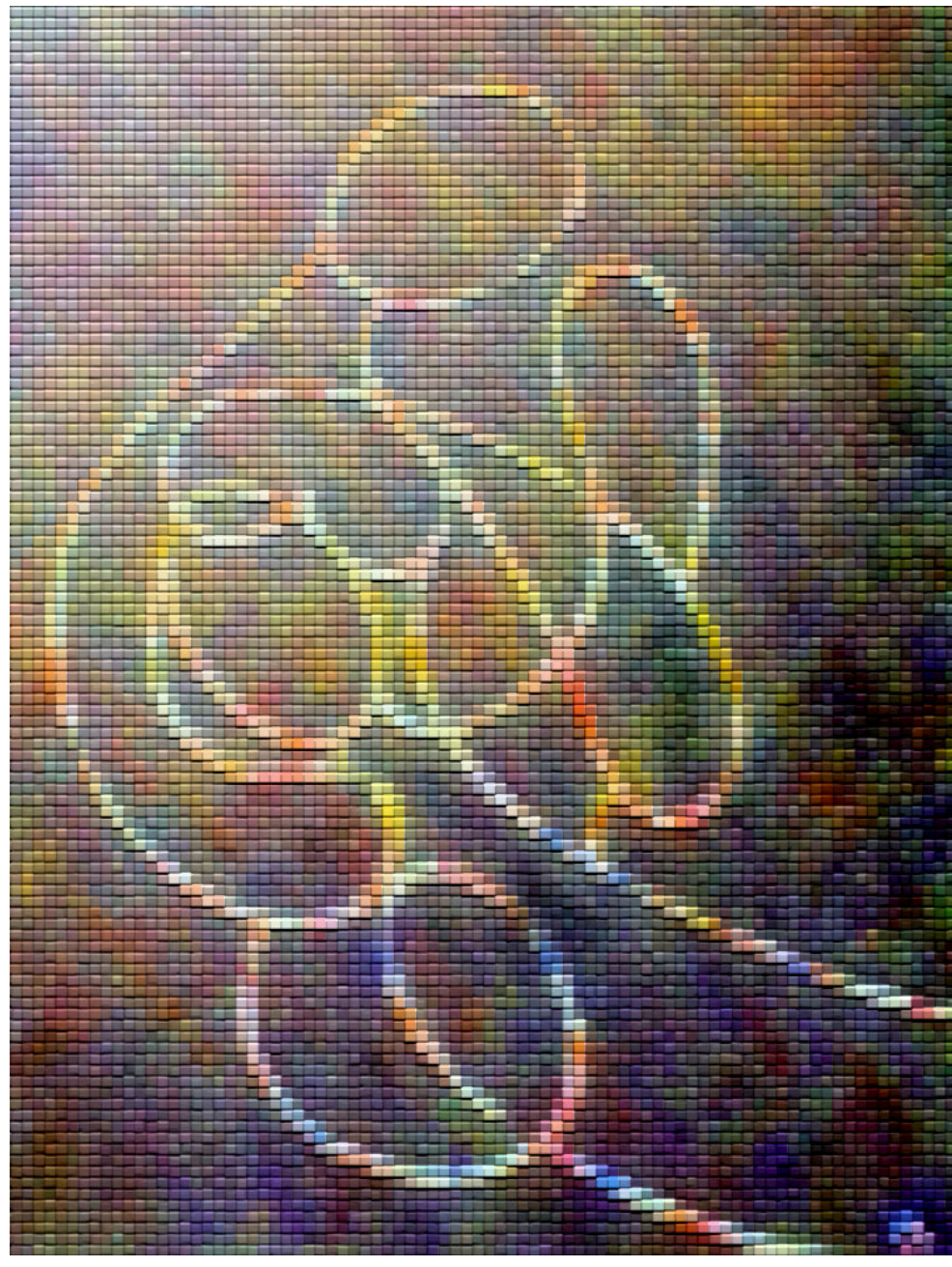

Figura 28 - Imagem simulando um mosaico através de recurso de edição de imagem em computador. (Fonte: arquivo pessoal)
Para facilitar a visualização das cores, também foi utilizado um recurso de computador que simula um mosaico, apresentando o desenho com quadrados com as cores determinadas separadas de modo que é possível visualizar individualmente grupos de pastilhas de cores diferentes que, juntas, resultam numa impressão de outras cores.

\subsubsection{Corte das pastilhas}

\section{O instrumento para cortar as} pastilhas é a torquês; existe uma torquês específica para cortar pastilhas de vidro que tem a ponta de metal duro (o mesmo material presente em brocas e serras circulares, que é importante para que as pastilhas não estilhassem ao serem cortadas) e uma mola para que não se tenha o trabalho de abrir a torquês novamente a

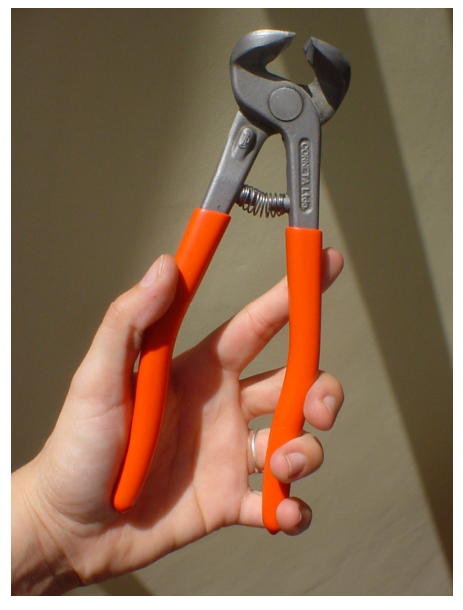

Figura 29 - Torquês para corte de pastilhas de vidro. (Foto da autora) 

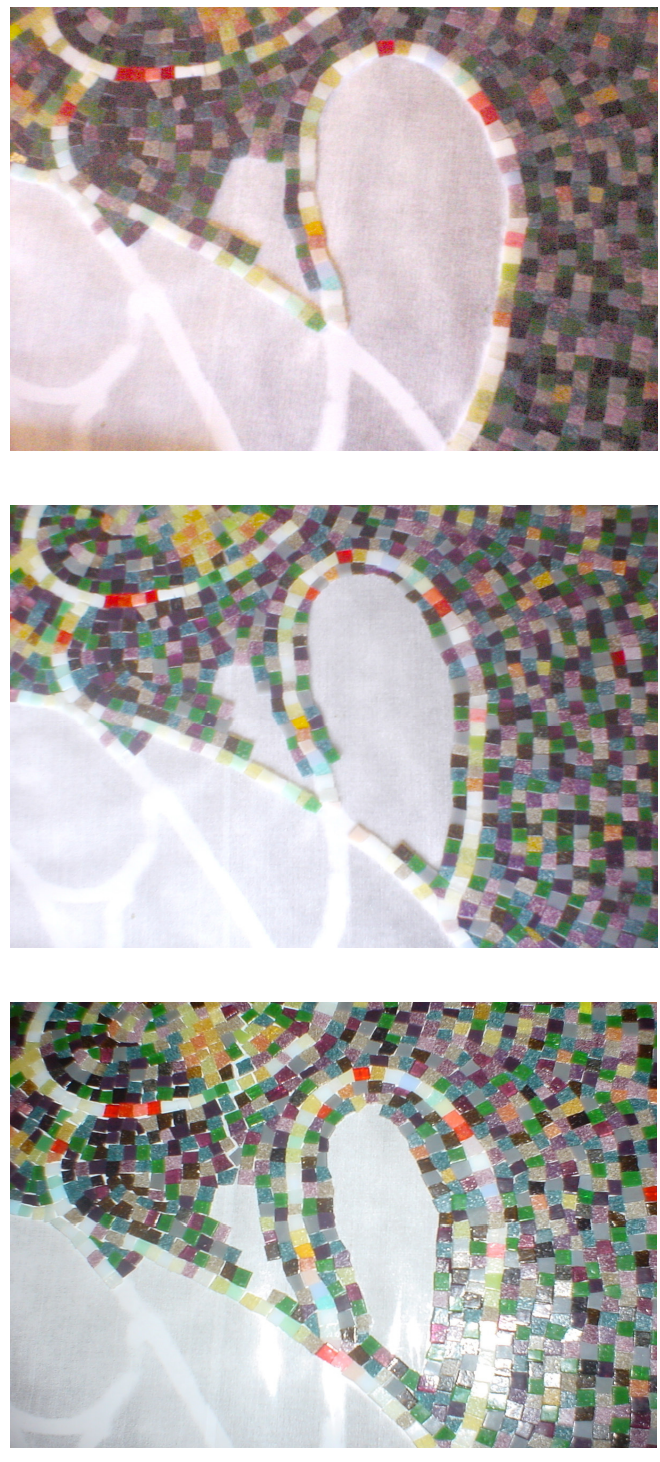

cada corte.

O padrão utilizado neste mosaico é de pastilhas cortadas em quatro partes; elas têm $2 \times 2 \mathrm{~cm}$ e se transformam em quadradinhos irregulares de aproximadamente $1 \times 1 \mathrm{~cm}$.

Para executar este mosaico, foram utilizadas pastilhas previamente cortadas, porém muitas foram novamente cortadas durante a execução para adquirir a forma que se encaixa melhor.

\subsubsection{Colocação das pastilhas}

A colocação das pastilhas foi feita pelo método indireto sobre o cartão. Tendo em mãos uma fotografia da pintura para seguir as cores originais, as pastilhas foram dispostas seguindo as curvas, elemento priorizado no desenho. A

Figura 30 - Seqüência de colocação das pastilhas em uma parte do mosaico Laços. (Fotos da autora) colocação começou com as pastilhas com cores claras que compõem as curvas e, em seguida, foram dispostas, seguindo o mesmo andamento, as pastilhas que compõem o fundo com cores escuras. 
Apesar de estar executando um mosaico a partir de uma pintura, a autora não pensou em momento algum que estaria fazendo uma reprodução. Dentro dos limites das linhas e das cores, ainda sobrava bastante espaço para a criação. Durante a execução, a autora visou expressar-se tirando partido da técnica do mosaico, tendo em mente a idéia de que seria possível conferir diferentes elementos a Laços.

A parte final desta etapa foi a substituição de algumas pastilhas por outras de diferentes cores. Foram trocadas algumas pastilhas escuras e substituídas por outras claras e o oposto, para clarear e escurecer algumas áreas, e também foram acrescentadas pastilhas azuis e vermelhas que são mais chamativas e vibrantes. Por causa dessas características, essas foram dispostas em pequena quantidade e com certa distância entre elas. Nesta etapa, a fotografia não foi seguida tanto quando nas anteriores, pois o objetivo não era fazer uma reprodução em mosaico de uma pintura, mas sim mostrar o que pode ser feito em mosaico e aproveitar melhor as características do material para valorizar a obra final. 


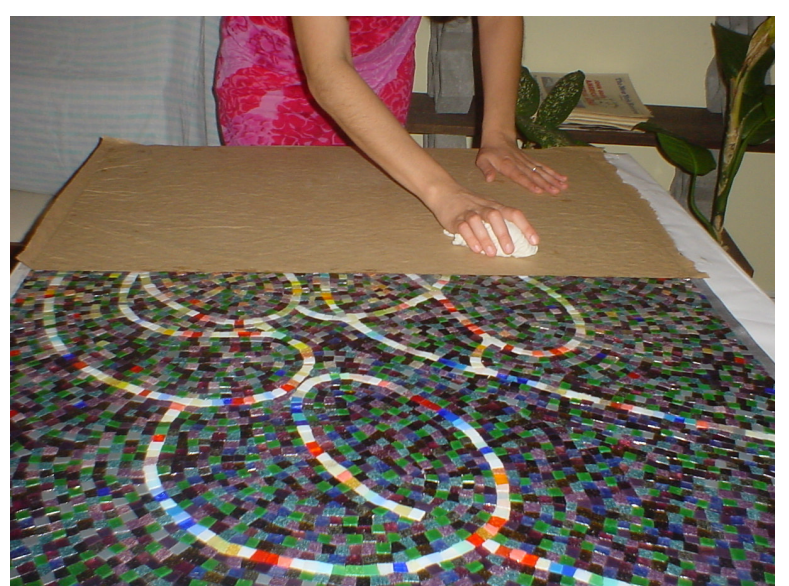

Figura 31 - Colagem do papel sobre o mosaico. (Foto de Rute Bevilaqua)

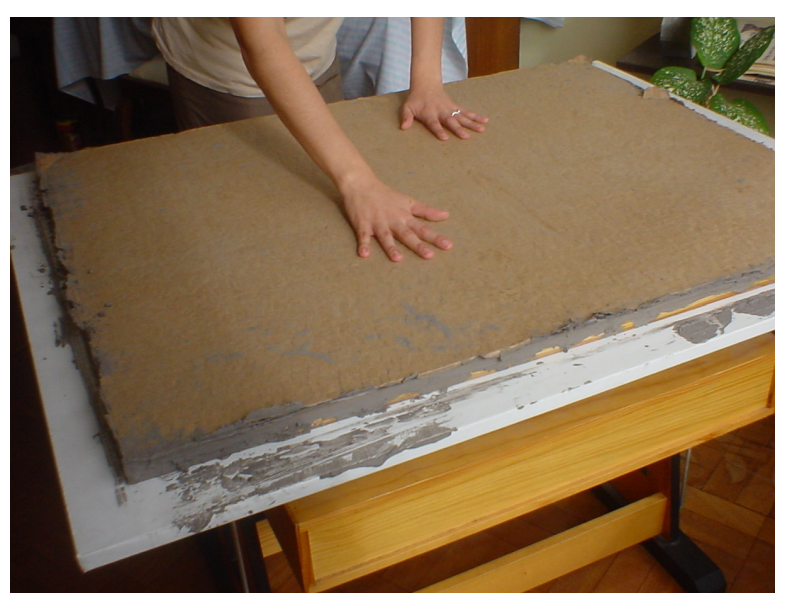

Figura 32 - Colocação do mosaico sobre sua superfície definitiva. (Foto de Rute Bevilaqua)

\subsubsection{Colagem das pastilhas no papel}

Esta etapa consiste em passar cola no papel e colocálo sobre o mosaico.

Já com a cola seca, a placa de papel com pastilhas foi virada (papel para baixo e a face traseira das pastilhas para cima) e aquelas peças que eventualmente soltaram-se do papel foram novamente coladas.

Por se tratar de um mosaico de pequena dimensão e por não haver necessidade de transportá-lo para outro local para a aplicação na superfície definitiva, optou-se por não cortar o papel com o mosaico em placas separadas. Normalmente ele é cortado em placas de cerca de $30 \times 30 \mathrm{~cm}$.

\subsubsection{Colocação do mosaico no painel}

A argamassa foi aplicada à superfície definitiva e a placa de papel com o mosaico foi colocada sobre a superfície. 


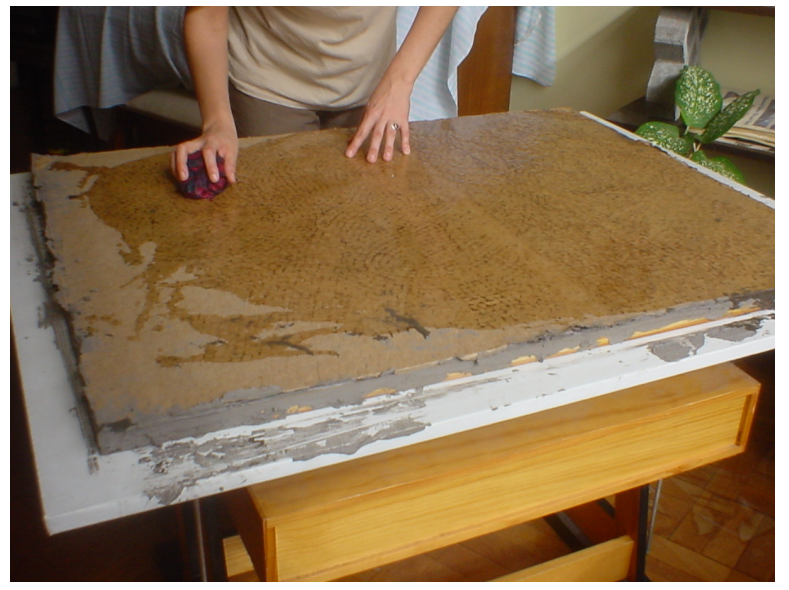

Figura 33 - Superfície do mosaico sendo molhada para soltar a cola. (Foto de Rute Bevilaqua)

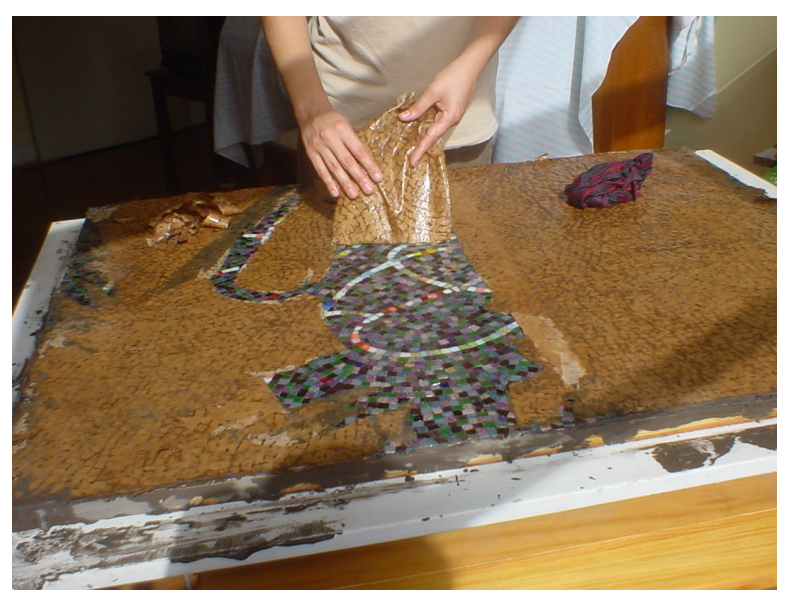

Figura 34 - Retirada do papel. (Foto de Rute Bevilaqua)
Para este mosaico, foi feita a opção por nivelar a superfície apenas pressionando-o sobre a massa com as mãos, o que resultou em uma superfície irregular.

A argamassa utilizada é específica para pastilhas de vidro. Ela é utilizada também como rejunte, Foi utilizada a cor cinza-escuro.

\subsubsection{Retirada do papel e finalização}

O papel foi retirado depois que a argamassa já estava seca. Para isso bastou molhar a superfície do mosaico para soltar o papel.

Depois de retirado o papel, ainda foi necessário limpar bem a superfície para retirar o excesso de cola e argamassa. A argamassa teve de ser novamente aplicada em partes onde faltou rejunte e para fixar algumas pastilhas que se soltaram durante a retirada do papel. 


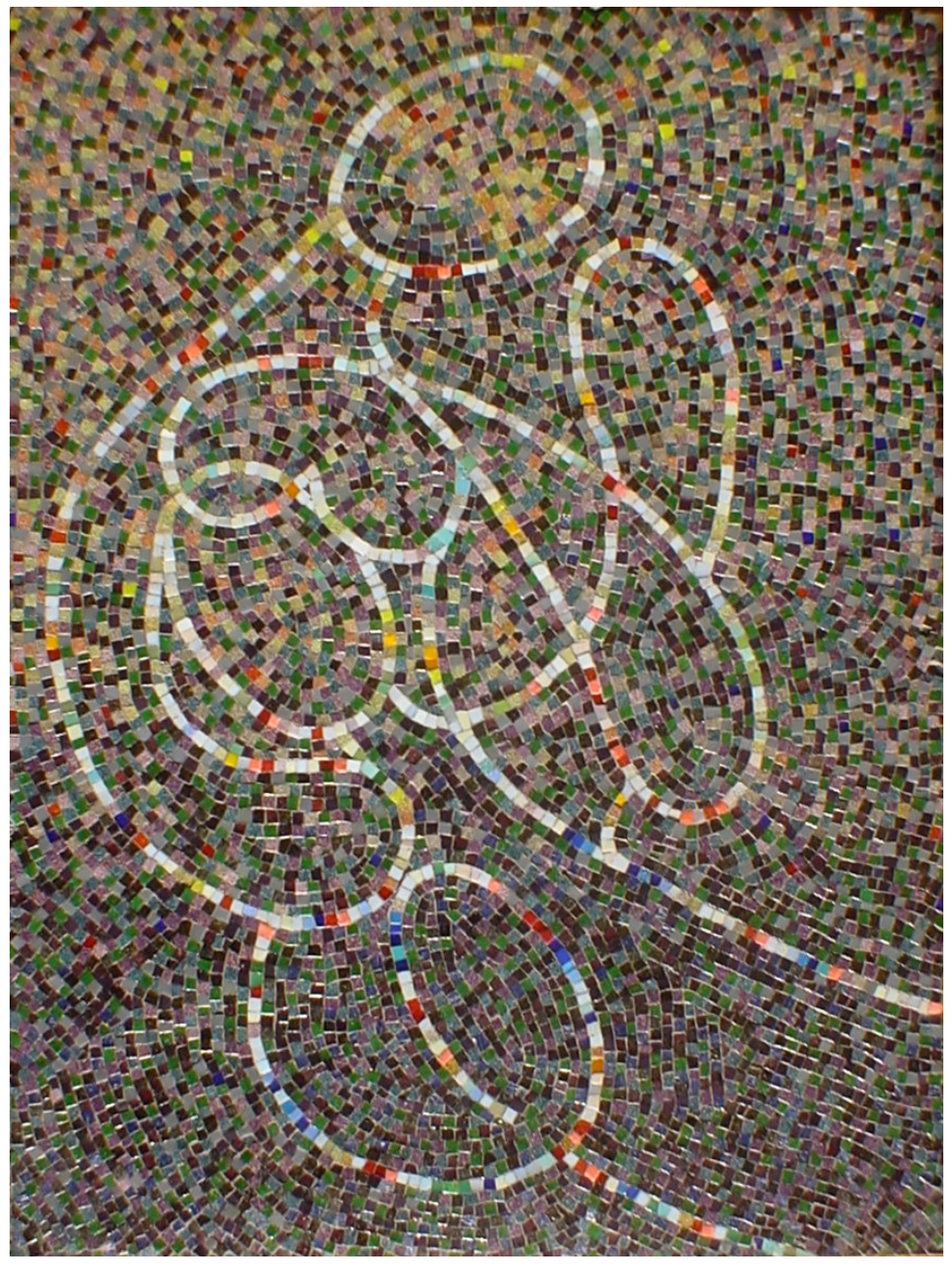

Figura 35 - Painel em mosaico Laços finalizado. (Foto da autora)
O mosaico de $105 \times 80 \mathrm{~cm}$ ficou com aproximadamente 8500 peças e o painel com cerca de $20 \mathrm{~kg}$.

\subsubsection{Considerações sobre a execução do painel}

Ao fazer uma composição em mosaico, são seguidas regras. No caso deste, tanto as pastilhas das linhas, como as do fundo, seguiram as linhas. Porém, essas regras não foram seguidas de modo mecânico, e sim com um espírito criativo. Para cada pastilha colocada, houve um processo de decisão da cor e da forma a ser utilizada.

Sendo criativos, seguimos regras, e quebramos parâmetros ${ }^{26}$. Em diversos momentos foi preciso buscar novas soluções, quando a geometria não permitia soluções com pastilhas cortadas em forma quadrada, por exemplo, e, também, quando foi trabalhada a parte de contrastes

\footnotetext{
${ }^{26}$ Seguir regras e quebrar parâmetros foi a lição básica da disciplina $O$ Processo Criativo dos professores Dr. Carlos Alberto Inácio Alexandre e Dra. Cibele Haddad Taralli, cursada no $2^{\circ}$ Semestre de 2004.
} 


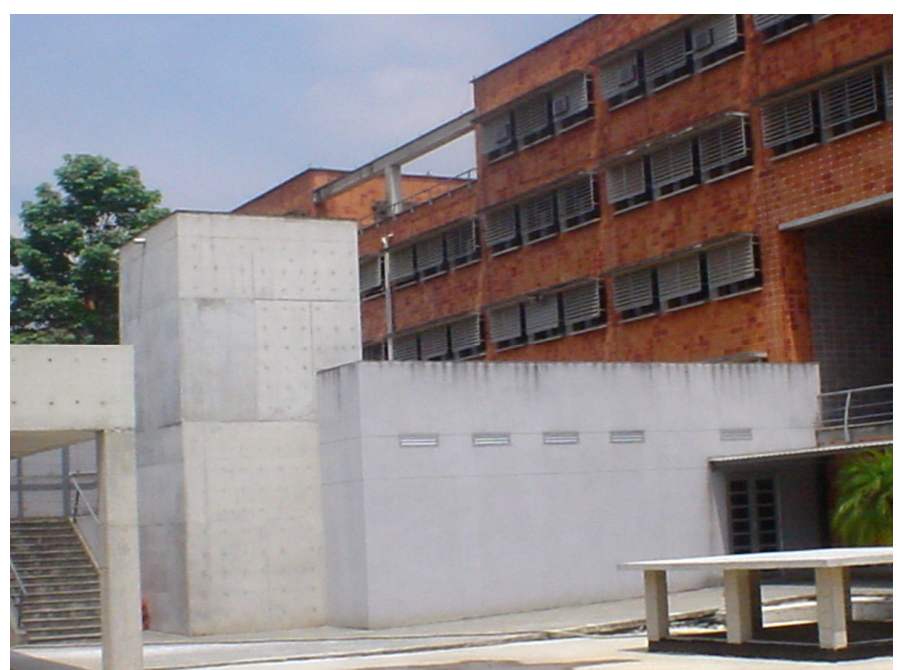

Figura 36 - Capela antes da implantação do mosaico. (Foto da autora)

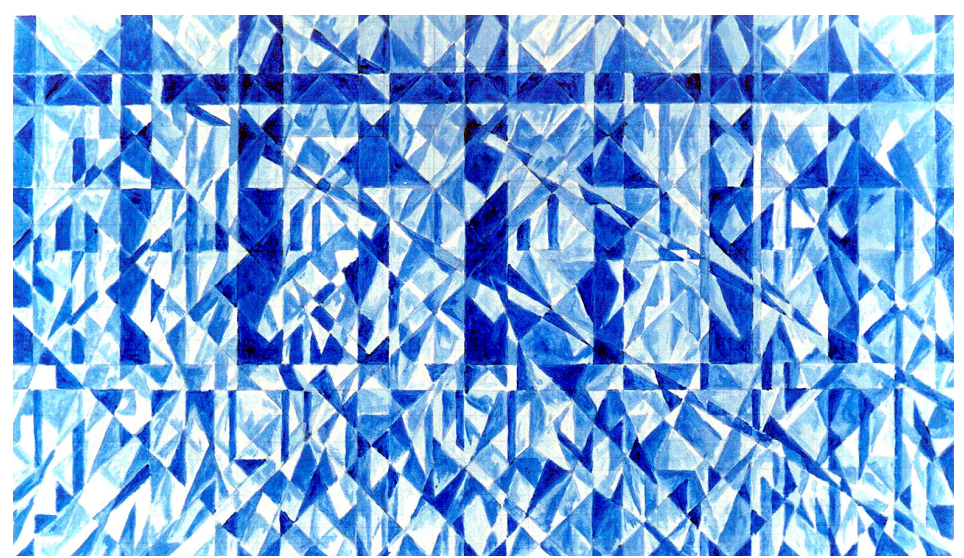

Figura 37 - Projeto do mosaico da capela. (imagem cedida pelo artista) inserindo-se pastilhas de cores diferentes daquelas preestabelecidas em algumas áreas.

\subsection{Execução do mural}

\subsubsection{Projeto}

O projeto deste mural em mosaico foi feito pelo artista plástico Claudio Tozzi e executado por uma equipe coordenada pelo mosaicista Sérgio Secches para uma capela na UNIFIEO, em Osasco, SP, projetada por Bruno Padovano.

A composição conta com diversos eixos na horizontal, vertical e diagonal que são visíveis pelo seu preenchimento com diversos tons de azul. As cruzes são evidenciadas pelo preenchimento com tons mais escuros e pela disposição no centro das superfícies e outra no encontro de duas superfícies. Percebe-se claramente uma intenção de explorar a tridimensionalidade pela integração dos planos. 


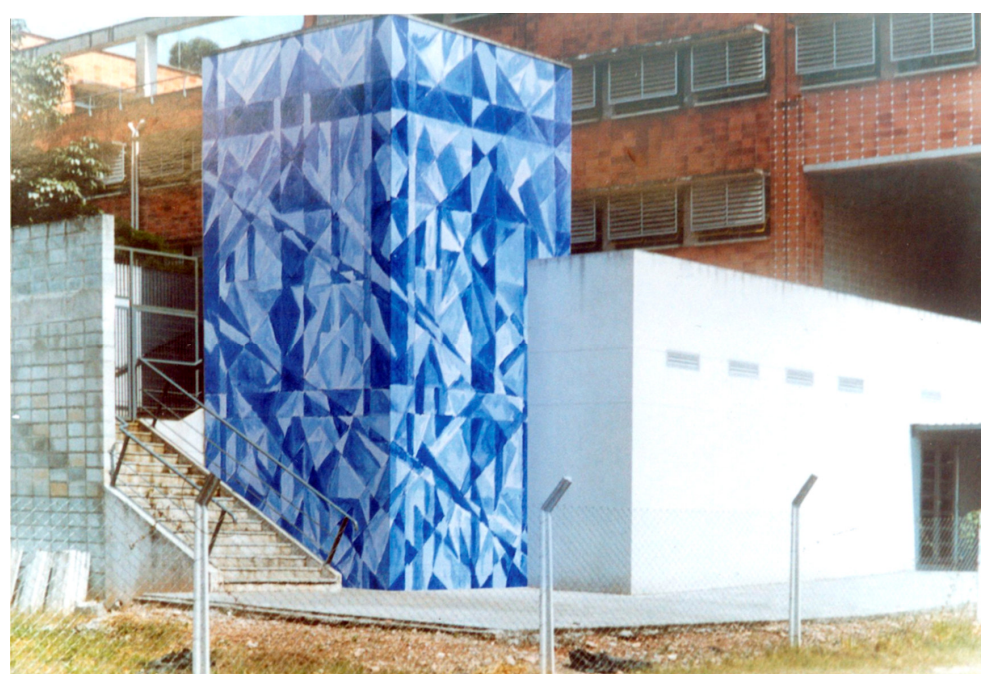

Figura 38 - Fotomontagem prevendo a aplicação do mosaico na capela. (Imagem cedida pelo artista)
Apesar de o projeto contar com um elemento de grande força simbólica, e mesmo com uma escala também grande, a cruz não aparece como um elemento opressor. Essa sutileza foi possível pela multiplicação deste mesmo elemento.

Foi feito um estudo de como ficaria o mosaico aplicando-o à fachada da capela em um programa de edição de imagens.

\subsubsection{Preparação do cartão}

O cartão foi riscado manualmente sobre a bancada de trabalho no ateliê. Por não haver espaço físico suficiente para a montagem de todo o mural, ele foi dividido em quatro partes. Todo o processo de execução do mosaico foi repetido a cada vez que uma das partes do trabalho estava pronta. 


\subsubsection{Estudo cromático}

Cada área do desenho tinha determinados tons de azul. Pastilhas de cores variadas foram divididas em grupos. Cada grupo de cores estaria em uma área determinada do desenho. No caso de um trabalho em equipe é importante ter isso bem definido para que haja uma uniformidade de todo o trabalho executado.

\subsubsection{Corte das pastilhas}

Para este mosaico, a maioria das pastilhas não chegariam a ser cortadas e os cortes nas áreas onde passam diagonais, para serem precisos, teriam de ser feitos durante a colocação das pastilhas. Por isso, não haveria motivo, nem meios, para cortá-las antecipadamente. 

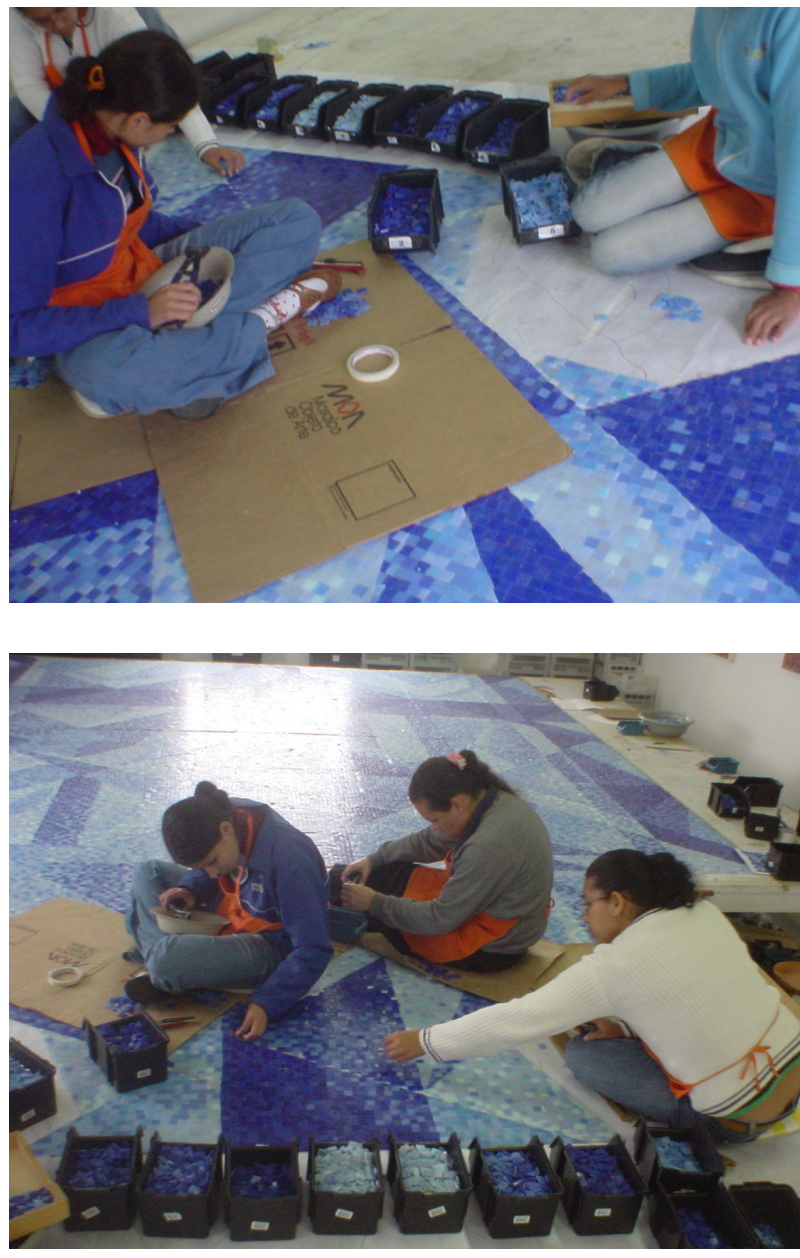

Figura 39 - Mosaicistas trabalhando na colocação das pastilhas. (Fotos da autora)

\subsubsection{Colocação das pastilhas}

A colocação das pastilhas foi feita pelo método indireto no ateliê. Por se tratar de um mosaico de grandes dimensões que vão além do espaço físico do ateliê, esta etapa foi realizada três vezes, sendo cada uma das três faces do mosaico realizada a cada vez. Secches teve o cuidado de começar a execução pela face menos aparente, voltada ao fundo do terreno, e deixar por último a da frente da capela.

O trabalho foi realizado pela equipe de mosaicistas que foi orientada a dispor as pastilhas de acordo com as áreas de cor determinadas. Outra orientação de Secches foi que as pastilhas nos eixos horizontais e verticais não fossem perfeitamente alinhadas, o que deixaria o mosaico com um aspecto mais próximo ao desenho.

Ao terminar de executar a primeira face do mural, o artista autor do projeto foi ao ateliê para verificar e aprovar o trabalho executado até então. 


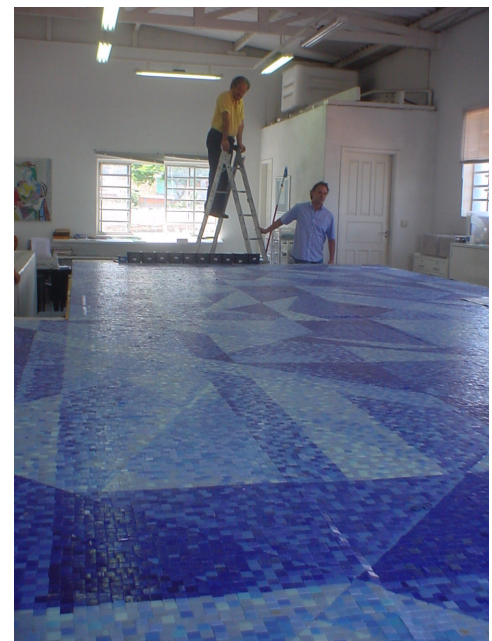

Figura 40 - Claudio Tozzi (na escada) e Sérgio Secches visualizando 0 mosaico. (Foto da autora)

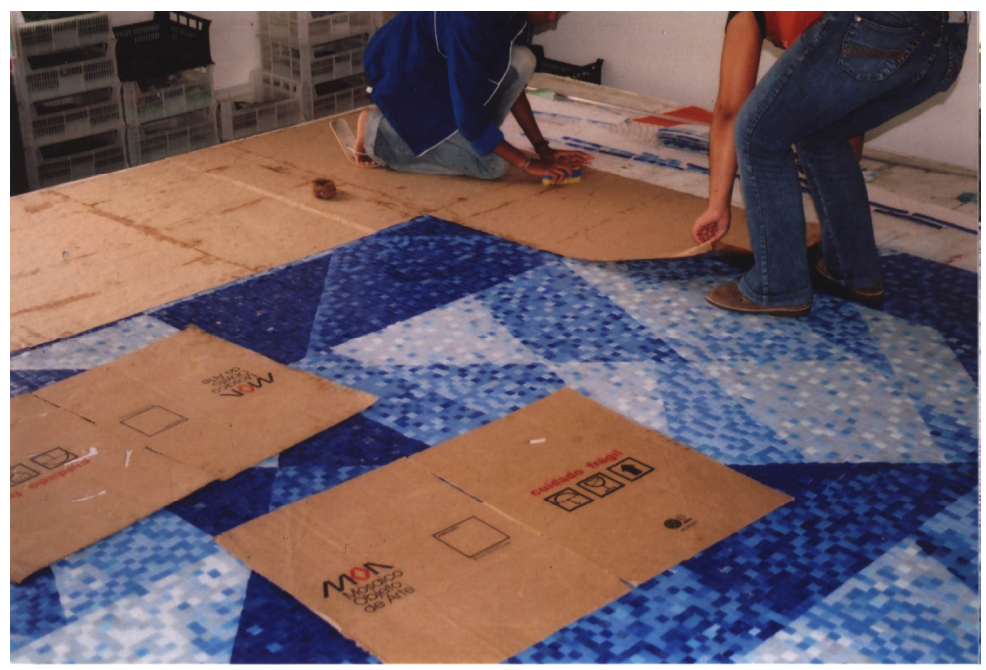

Figura 41 - Colagem das pastilhas no papel. (Foto de Sérgio Secches)
Para visualizar o mosaico a uma maior distância é preciso subir uma escada.

\subsubsection{Colagem das pastilhas no papel}

O processo de colagem das pastilhas no papel foi igual ao do painel, com a diferença de que, após colado, todo o mosaico foi cuidadosamente cortado em placas numeradas de cerca de $40 \times 40 \mathrm{~cm}$, as quais foram então embaladas e transportadas para o local da aplicação.

\subsubsection{Colocação do mosaico na parede}

Para diminuir o tempo de execução, a colocação do mosaico na superfície definitiva foi iniciada enquanto outras partes do mosaico eram feitas no ateliê. O colocador tinha em mãos um esquema com a numeração mostrando a posição de cada placa, também numerada, a ser colocada. 


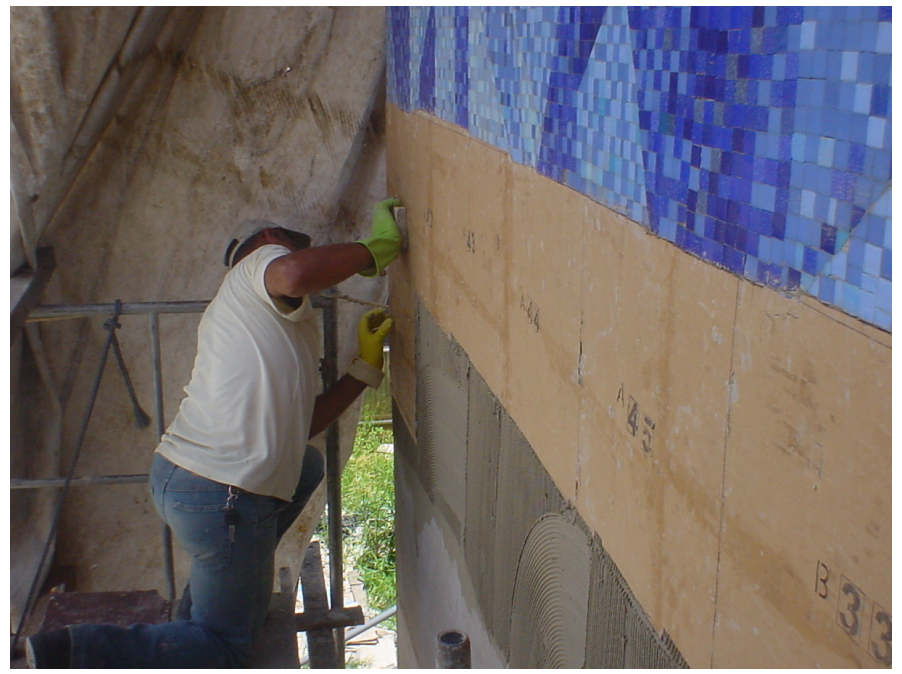

Figura 42 - Colocação. (Foto da autora)

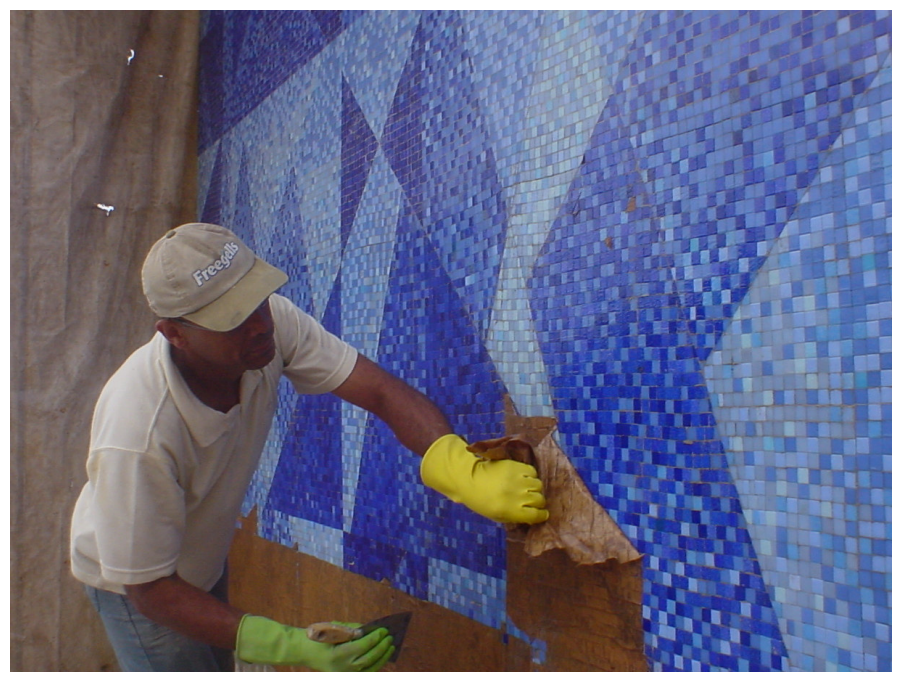

Figura 43 - Retirada do papel. (Foto da autora)
A argamassa específica para pastilhas de vidro utilizada era cinza-claro, a mesma massa seria utilizada também para o rejunte. Assim como é feito em assentamento de cerâmica, a argamassa era colocada sobre a parede para depois ser aplicado o mosaico.

Sobre a argamassa, as placas com as partes do mosaico foram colocadas nos lugares determinados sendo novamente encaixadas umas às outras, como em uma montagem de um quebra-cabeça.

\subsubsection{Retirada do papel e finalização}

Ao contrário do painel, em que a retirada do papel se deu com a argamassa completamente seca, na execução do mural, durante a retirada do papel a argamassa não estava completamente seca, ela estava firme o suficiente para permitir a retirada do papel e mole o suficiente para permitir pequenos deslocamentos das pastilhas. Isso é importante porque é preciso que o colocador visualize o espaço entre as pastilhas para que possa perceber se o espaço entre as 


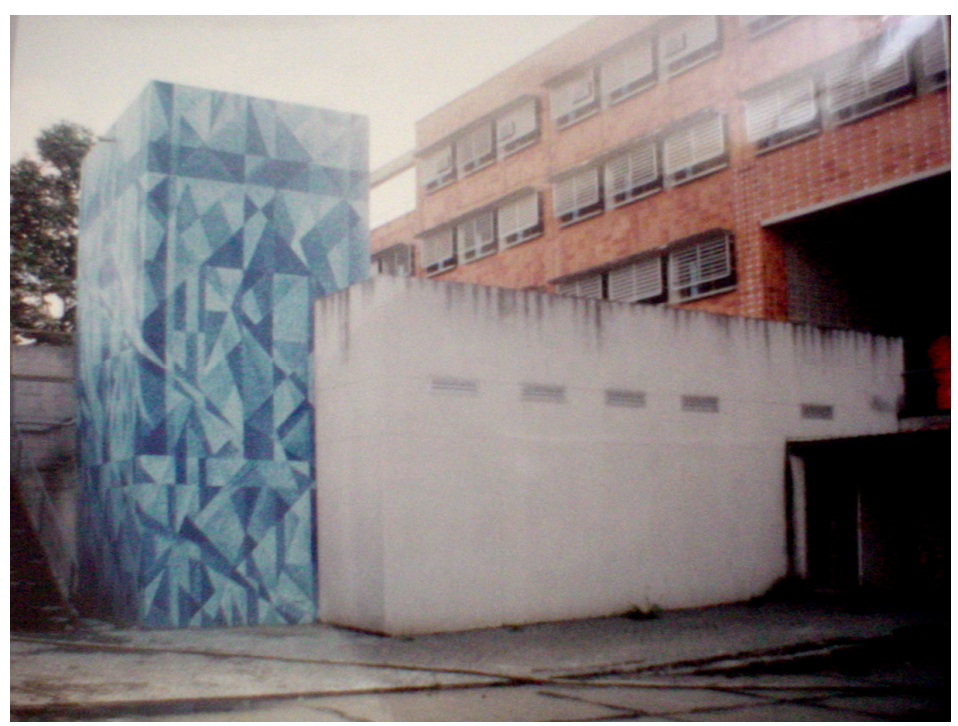

Figura 44 - Capela com o mosaico finalizado. (Foto de Claudio Tozzi) placas colocadas ficou igual ao espaço para o rejunte entre as demais pastilhas do mosaico e para que possa fazer os ajustes necessários para que o recorte das placas não seja visível no trabalho pronto.

Além da colocação das placas do mosaico pelo método indireto, coube ao colocador a aplicação de algumas pastilhas pelo método direto em uma pequena área que não foi preenchida pelo mosaico trazido do ateliê e outras pequenas correções. Depois o mosaico foi rejuntado e lavado.

\subsubsection{Considerações sobre a execução do mural}

Durante todo o processo acompanhado pela autora, o que mais Ihe chamou a atenção foi o fato de que, desde o projeto, até a execução, o mosaico não é tratado como uma obra de arte a ser aplicada à arquitetura, mas como projeto de arquitetura na fase de projeto e como construção durante a execução. 
Assim como em um projeto de arquitetura, o mural foi pensado em função do próprio edifício, do seu uso e do seu entorno, e, durante a execução, o mosaico era tratado como material de construção, o que, de fato, também vem a ser.

\subsection{O fazer mosaicos por Sérgio Secches}

Para encerrar este capítulo, aqui estão destacados alguns pontos levantados em conversa com o mosaicista Sérgio Secches. Nesta conversa, Secches falou sobre seu "caminho das pedrinhas", desde sua formação, até as suas considerações sobre as questões da expressão artística do mosaico, passando por seus primeiros trabalhos e sua experiência administrando um ateliê de mosaicos e executando, em mosaico, trabalhos de artistas consagrados. A entrevista foi conduzida pela autora no dia 24 de janeiro de 2007, no ateliê de Secches, e contou com a participação da 
jornalista Montserrat Bevilaqua ${ }^{27}$, convidada para facilitar a dinâmica e fluidez da conversa.

\subsubsection{Perfil de Sérgio Secches}

Sérgio Secches nasceu em São José do Rio Preto em 1962. Formado arquiteto pela Universidade Braz Cubas, há 12 anos tem seu próprio ateliê de mosaicos, Mosaico Objeto de Arte. Vive e trabalha em São Bernardo do Campo.

Entre os mosaicos executados por equipes coordenadas por Secches, citados nesta dissertação, estão o de Aldemir Martins, no Centro Cultural Dragão do Mar; Alex Flemming, na Estação Santo André; Claudio Tozzi, na Cultura Inglesa, Edifício Exclusive, Novotel e Fórum Trabalhista; Herton Roitman, na Seguradora Porto Seguro; e Tomie Ohtake, na Estação Consolação. Além destes, Secches executou mosaicos dos artistas Adriana Banfi, Antonio

${ }^{27}$ Montserrat Bevilaqua (1967-) é jornalista com experiência em jornalismo político, econômico e de cidades, e assessoria de imprensa. Trabalhou na Folha da Manhã (Folha de S. Paulo), Diário Popular, Diário do Grande $A B C$, assessoria de imprensa da Câmara de Santo André, Prefeituras de Mauá, Diadema e São Paulo e Instituto São Paulo de Políticas Públicas. 


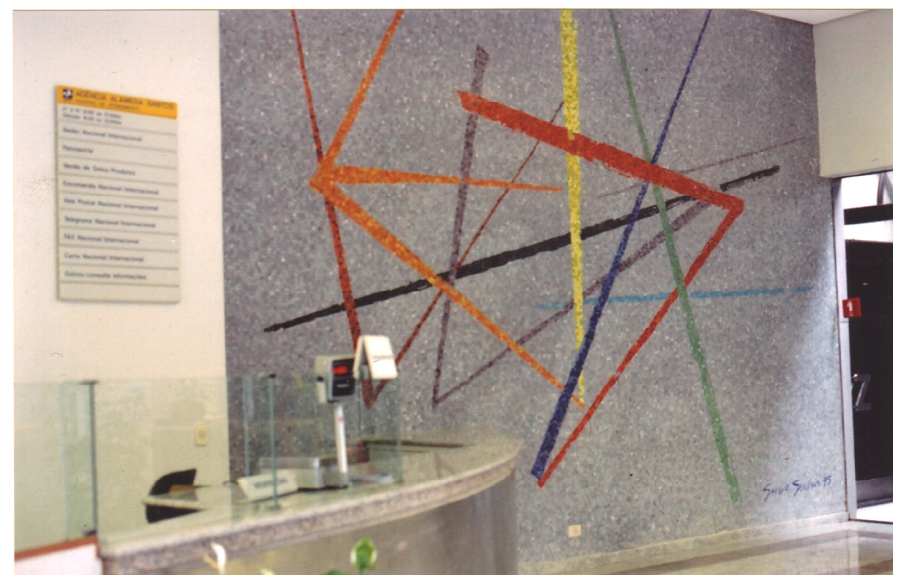

Figura 45 - Mosaico de Sérgio Secches, vencedor do concurso promovido pelos Correios. (Foto de Sérgio Secches)

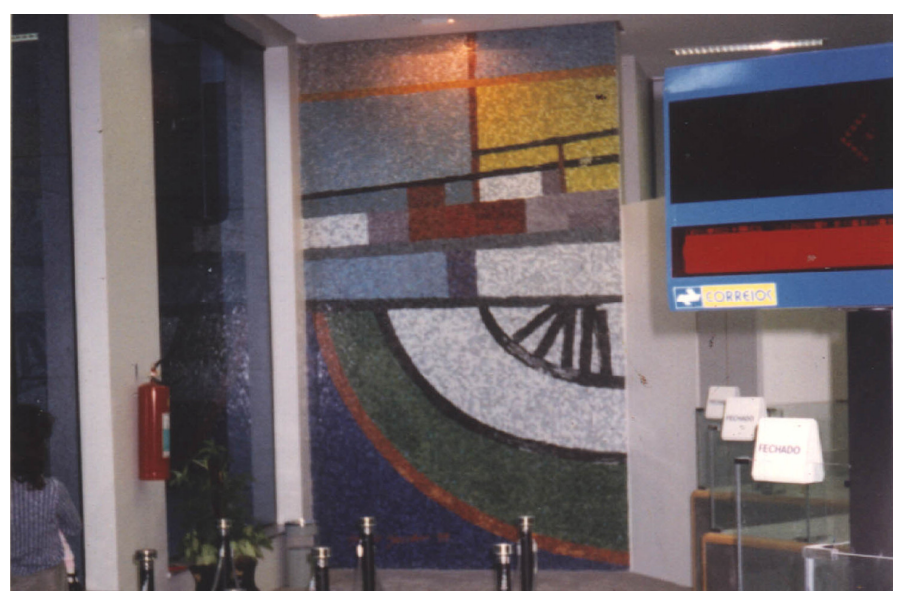

Figura 46 - Mosaico de Sérgio Secches, vencedor do concurso promovido pelos Correios. (Foto de Sérgio Secches)
Henrique Amaral, Gregório Gruber, Leda Catunda, Marcia Rothstein, Rubens Matuck, Silvio Oppenheim, Tomie Ohtake e Yara Tupynambá. ${ }^{28}$

\subsubsection{Participação em concursos}

Em 1995, Secches foi o vencedor do concurso "Murais Artísticos", promovido pelos Correios de São Paulo, trabalho composto de dois mosaicos na agência dos correios situada à Alameda Santos, 2224, que foram executados pelo Mosaico Objeto de Arte.

Em 1991 executou um trabalho vencedor de concurso para uma praça em Santo André - projeto painéis de rua - na Praça $4^{\circ}$ Centenário, um painel em pintura com tinta automotiva em chapa galvanizada que teve algumas pastilhas aplicadas, dando textura.

\footnotetext{
${ }^{28}$ Adriana Banfi, Antonio Henrique Amaral, Claudio Tozzi, Herton Roitman, Rubens Matuck e Tomie Ohtake tiveram seus mosaicos executados pela Moasico Objeto de Arte. Os demais pela Vidrotil, sendo que Claudio Tozzi e Tomie Ohtake tiveram trabalhos executados tanto pela mosaico.
} 
Em 1983 participou do 6ํㅗㅁ Sala de São Bernardo do Campo e foi ganhador do Prêmio Aquisição da prefeitura de São Bernardo do Campo. Sua obra Projeção de um menino em um quadro contraditório é uma pintura com várias texturas, dando uma tridimensionalidade, que retrata um menininho de pijama olhando uma porta aberta com olhar apreensivo. Secches estudava pintura de forma autodidata.

\subsubsection{Faculdade de arquitetura}

Em 1979, Secches optou por estudar Arquitetura porque achava que era uma profissão a qual iria se adaptar devido ao seu gosto por desenho. Gostou do curso, mas achava que as correntes mais fortes da Arquitetura tinham falhas na parte estética, humana, e na forma de projetar, pois a Arquitetura devia utilizar a estética em benefício das pessoas, no sentido humano, e não de poder do capital. Ele questionava a arquitetura como veículo de comunicação.

O estudante achava que os materiais de construção eram demasiadamente monocromáticos, que havia muito 
cinza no concreto armado. Seguia-se uma corrente que procurava explorar os materiais naturais, mostrar a beleza da estrutura e dos materiais empregados, mas Secches sentia falta de materiais mais coloridos.

Um dia, ao passar pela Estação Sé do metrô, deparouse com o mosaico Colcha de Retalhos, de Claudio Tozzi, e, segundo Secches, este foi um momento de muita alegria ao ver que existia um material de construção com todas aquelas cores, aplicado de uma forma diferente e que era uma obra de arte.

\subsubsection{Primeiros trabalhos}

Secches começou a trabalhar durante meio período na Vidrotil, em 1985, o único lugar onde se executavam mosaicos naquela época, ficando aí até 2001, mantendo paralelamente seu trabalho em escritório de Arquitetura e em seu próprio ateliê de mosaico. 
Apesar de, nos anos 50, a Vidrotil ter executado mosaicos de Di Cavalcanti e Portinari, por um período passaram a ser raras as encomendas de mosaicos artísticos. Ele estava lá exatamente em um momento que começaram a aparecer em maior quantidade esses trabalhos artísticos.

Os mosaicos artísticos tinham regras de construção muito rígidas: as pastilhas deveriam ser quase sempre de $1 \times 1^{29}$ ou $2 \times 2$, nunca misturadas, definia-se uma cor para cada área, não havendo espaço para mistura de cor, e os desenhos deveriam ser dispostos de forma radial, e eles se fecharem no centro, encerrando-se nele mesmo, e em torno das figuras se fazia uma aura de pastilhas. Secches achava que essas regras não tinham sentido. Segundo ele, "A beleza não tem regra, a beleza está na expressão."

Secches percebeu que as pastilhas podiam ser trabalhadas como se fossem tinta, que era possível explorar o expressionismo no trabalho e até mesmo baratear a execução do mosaico artístico, ao empregar, também, as pastilhas com formatos diversos e construção diferente, e

\footnotetext{
${ }^{29}$ As pastilhas padrão de $2 \times 2 \mathrm{~cm}$ cortadas em quatro partes de $1 \times 1 \mathrm{~cm}$
} 
fazendo um trabalho de qualidade.

\subsubsection{Serafino Faro}

Secches chegou a fazer curso com o pintor e mosaicista Serafino Faro (1915-2003) que foi mosaicista na Vidrotil e ministrava curso em São Paulo no Conservatório Marcelo Tupinambá. Segundo Secches, Faro era um excelente colorista, "coisa de gênio, as cores vibrando".

Faro era italiano, estudou Artes na Academia São Lucas em Roma, freqüentou o ateliê de mosaico do Vaticano e mudou-se para São Paulo em $1949 .^{30}$ Ele foi responsável pela execução de Colcha de Retalhos, de Claudio Tozzi, na Estação Sé do metrô, em 1979.

\footnotetext{
${ }^{30}$ COELHO, Isabel Ruas Pereira. Painéis em mosaico na arquitetura moderna paulista. - 1945-1964 São Paulo: dissertação de mestrado. Faculdade de Arquitetura e Urbanismo da Universidade de São Paulo, 2000. p. 217.
} 


\subsubsection{Empresa de mosaicos}

Em 1994, Secches abriu seu próprio ateliê de mosaico, Mosaico Objeto de Arte. Normalmente o ateliê conta com cinco funcionárias, este número varia conforme o volume de trabalho. Secches supervisiona e orienta a equipe no que se refere à forma e cor na execução dos mosaicos.

Além do trabalho com mosaicos, ele precisa administrar a empresa. Não existe uma regulamentação específica para ateliês com funcionários, nem incentivos fiscais pelo fato de a empresa realizar trabalhos de arte. Para Secches, manter uma empresa como esta é difícil, mas, ao mesmo tempo, desenvolver trabalhos junto a artistas e arquitetos, e ter seu trabalho reconhecido, é gratificante.

\subsubsection{Mosaicos decorativos}

Como empresa, Secches também trabalha com mosaicos decorativos, barras de piscina, faixas, degradês, tartarugas e golfinhos, e trabalhos abstratos simples. Pelo 
volume de trabalho, não seria possível manter a empresa apenas com os mosaicos artísticos.

Para Secches, a maioria das pessoas não vê o mosaico como arte, mas como decoração. Em uma tentativa de notabilizar o mosaico como arte, "comunicar algo que não seja só enfeitar uma parede", Secches costuma mostrar a esses clientes a possibilidade de fazer um mosaico artístico, mostrando, como exemplos, trabalhos de artistas que ele tem como referência, como Henri Matisse, Paul Cézzane, Aldemir Martins e Claudio Tozzi, e oferecendo-lhes a possibilidade de encomendar um trabalho nessa linha.

\subsubsection{Mosaicos de outros artistas}

Secches procura fazer uma leitura do trabalho de outro artista, do ritmo, da expressão, do conceito, para aplicar em mosaico. Às vezes, para acentuar a expressão da obra, chega a alterar a forma ou a cor, adaptando a expressão do artista à técnica do mosaico e à disponibilidade de cores. Segundo Secches, a obra do artista pode ganhar mais 


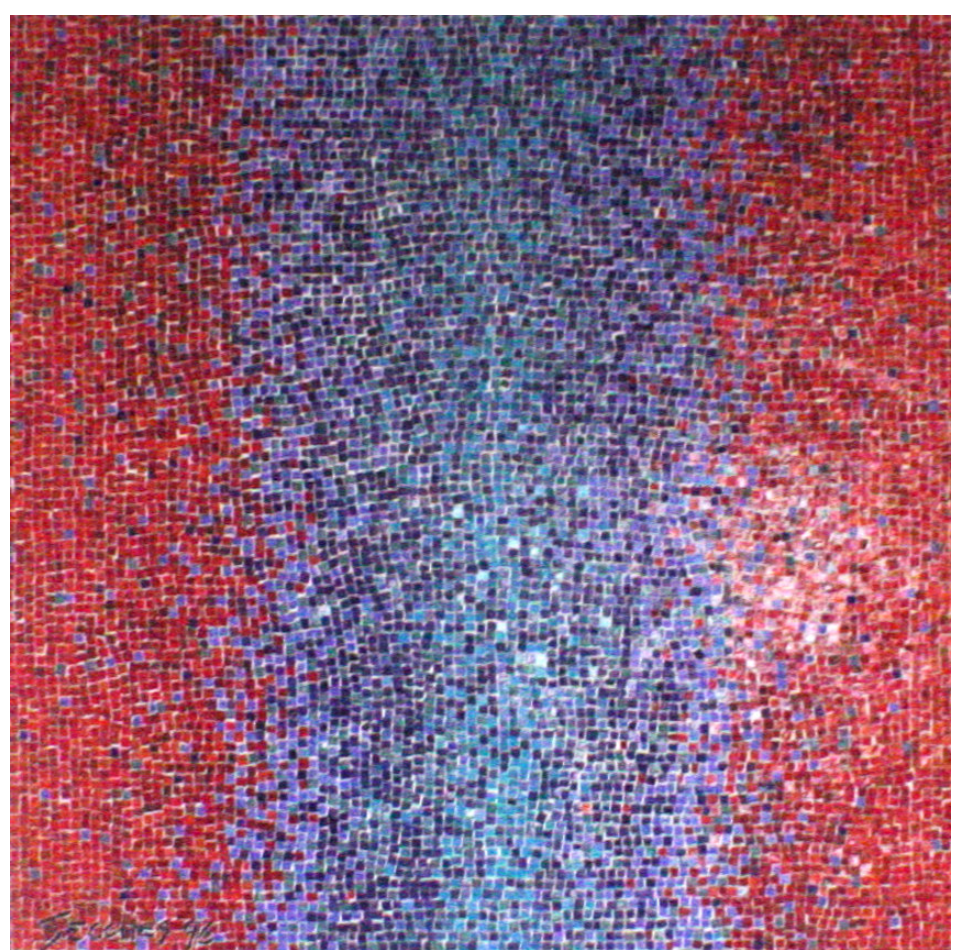

Figura 47 - Painel em mosaico com pastilhas azuis e vermelhas de Sérgio Secches. (Foto da autora) expressão com a interação com o espaço e com o público; o mosaico é um meio para isso.

\subsubsection{Cores no mosaico}

Para Secches, mosaico é uma técnica pontilhista em que o artista tem de ter noção de mistura de cor, trabalhando com a síntese aditiva da cor que consiste em criar uma cor resultante ao misturar outras.

Em um painel que Secches mostrou em seu ateliê, 0 violeta entre o azul e o vermelho é uma cor resultante, uma cor que não existe, à distância o mosaico é como se misturasse a tinta.

\subsubsection{O mosaico em seu contexto}

Ao ser perguntado como é um bom projeto de mosaico, Secches respondeu que o mais importante é que o mosaico seja muito bem pensado para ser inserido em seu contexto, 
em seu espaço, visto que deverá ficar naquele espaço, visto pelas pessoas, por tempo indeterminado.

Secches citou como artistas que têm trabalhos ideais para mosaico Aldemir Martins, Tomie Ohtake, Herton Roitman, pela sua excelente compreensão do espaço, e Claudio Tozzi, que visa a integração com o edifício, o qual também tem essa compreensão do espaço por ser arquiteto, além de ter uma preocupação plástica.

\subsubsection{Mosaicos em painéis móveis}

Secches desenvolveu uma técnica para executar mosaicos em painéis móveis, painéis autônomos, assim como quadros ou esculturas, que não estão vinculados ao corpo da obra do edifício. Para ele, a vantagem do painel é que o artista fica livre da encomenda, portanto livre para desenvolver uma linguagem própria, seu próprio estilo.

A solução de mosaico em painéis móveis também pode ser interessante para o cliente, quando ele quer ter a possibilidade de poder levar o mosaico consigo, se mudar de 
endereço, como foi o caso do mosaico de Herton Roitman que Secches executou para a Seguradora Porto Seguro.

O trabalho em painéis móveis está gerando um conceito novo, enquanto as pessoas ainda estão acostumadas ao mosaico na construção e entendem o mosaico como uma coisa pesada. Para Secches, esses trabalhos ainda enfrentam um preconceito de não serem vistos como obra de arte com uma aura tão valiosa quanto uma pintura ou escultura. Ele está procurando passar uma imagem mais leve nesses trabalhos para acabar com o esteriótipo de o mosaico ser um trabalho pesado.

\subsubsection{Senso comum}

Secches acha que não está na essência das pessoas a vontade de encomendar mosaicos, e, quando está, é uma coisa mais colorista, de decoração, para enfeitar ou dar destaque a uma parede. 


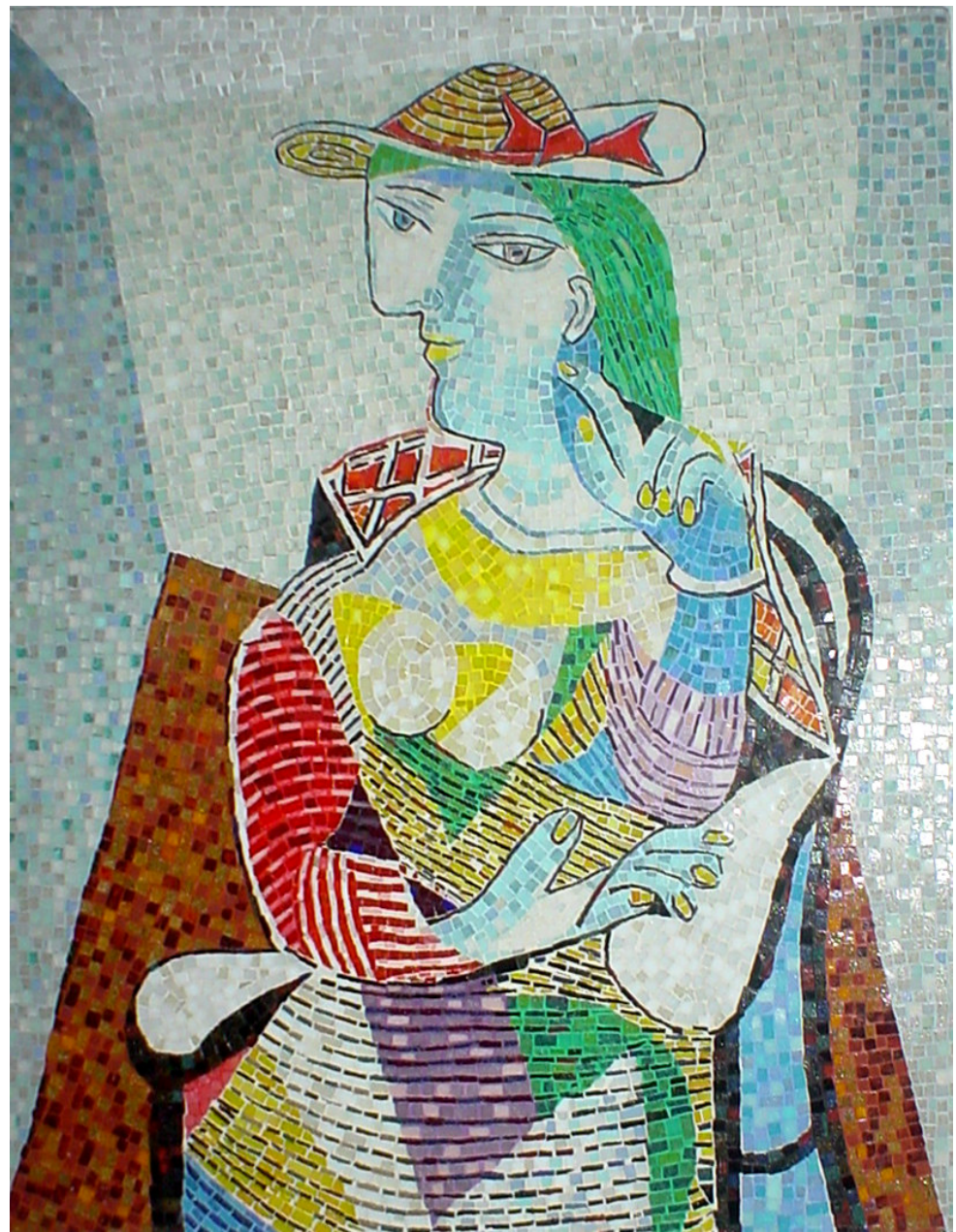

Figura 48 - Painel baseado no Retrato de Marie-Thérèse, de Picasso, executado em pastilha de vidro por Sérgio Secches. (Foto da autora)
Quando se trata de um trabalho artístico, se o artista é alguém já reconhecido, o trabalho não será mais julgado, já se sabe que é um trabalho de arte. Em geral, os artistas que projetam os mosaicos artísticos são escolhidos por concursos ou são convidados. É difícil alguém procurar o ateliê para fazer um trabalho de arte.

\subsubsection{Picasso no painel e Dalí no banheiro}

Um dos painéis móveis de Secches é o Retrato de Marie-Thérèse, de Pablo Picasso, que não é entendido pelo mosaicista como uma cópia, mas como uma releitura que pode redimensionar a importância do trabalho original, provocando uma experiência nova.

No dia da entrevista um Dalí estava sendo executado para o banheiro de uma residência. Montserrat Bevilaqua perguntou se dava mesmo para pôr um Dalí no banheiro. Secches respondeu que numa sala de banho de grandes dimensões "pode até ficar legal", e que em um banheiro com duas privadas, o que é surrealista, até combina. Ele riu e 
complementou que leu em uma reportagem que Dalí tinha um vaso sanitário de ouro em seu banheiro e, ao ser questionado sobre isso, respondeu que sonhava que todas as pessoas usassem uma privada de ouro.

\subsubsection{O que é mosaico}

Nas palavras de Secches: "Mosaico é dinâmica, vigor, é uma necessidade; a minha doença é o vigor nas coisas, talvez seja meu problema, e eu acho que o mosaico passa isso, é a antidegradação, tem esse lado meio rebelde, o Gaudi é uma rebeldia." 


\section{Espaço dos mosaicos}

O espaço é azul e pássaros voam através dele.

- Werner Heisenberg ${ }^{31}$

Abre-se este capítulo com considerações do artista plástico Claudio Tozzi, autor de diversos obras em mosaico relacionados ao espaço da arquitetura e da cidade.

A seguir apresenta-se uma amostra de mosaicos levantados majoritariamente em São Paulo, além de mais alguns relevantes em outras cidades. A seleção dos mosaicos foi feita pelo material, portanto o período deste estudo abrange um pouco mais de cinqüenta anos, começando com os mosaicos modernos do fim da década de 40 e indo até os

${ }^{31} \mathrm{O}$ físico Werner Heisenberg fez essa definição coerente, mas extremamente simplista de espaço durante uma conversa com um colega para alertá-lo que definir o espaço usando conceitos muito abstratos e sendo demasiadamente pretencioso é perigoso. FERRIS, Timothy. The whole shebang. New York: Simon \& Schuster, 1997. p. 320. 
mosaicos atuais. Os mosaicos levantados estão ordenados cronologicamente.

\subsection{Claudio Tozzi e o espaço do mosaico}

O artista plástico Claudio Tozzi é autor de diversas intervenções artísticas em espaços públicos. Ele recebeu a autora no dia 28 de janeiro de 2007 para uma conversa sobre a obra de arte no espaço da cidade e da arquitetura, focando a questão do mosaico.

\subsubsection{O projeto}

Ao ser perguntado sobre como é o processo de um artista para fazer um projeto para um mosaico, Tozzi respondeu que a primeira coisa a pensar é o espaço, seja da cidade ou do edifício, em que ele estará situado, e a segunda em questões específicas de sua construção. 


\subsubsection{O espaço}

Pensar o espaço consiste em estudar a sua leitura visual. Como em qualquer outro projeto de programação visual, é preciso estudar a relação do projeto com a escala e o entorno, que incluem a luz, as cores do ambiente e a questão da visão do observador, o que exige conhecimento do ângulo visual e das distâncias. Segundo Tozzi:

Do ponto de vista arquitetônico, a problemática de definição do espaço é central a todas as considerações técnicas e se constitui na questão essencial para focar o valor estrutural do edifício e do espaço construído. $O$ espaço da arquitetura seria então aquele propriamente "definido" que determina e resolve a complexidade "dentro e fora" e que atribui uma categoria autônoma, estrutural e poética, ao ambiente humano. Define e redefine contemporaneamente o espaço e o lugar, 
através da construção e simbiose com o ambiente e o contexto urbanístico. ${ }^{32}$

\subsubsection{O trabalho interdisciplinar}

O processo de projeto de um mural é o mesmo das soluções do arquiteto, por isso, dependendo de sua formação, alguns artistas plásticos encontram dificuldades para adequar sua obra ao espaço da cidade ou da arquitetura. Tozzi afirma que este é um trabalho conjunto:

É necessário que o designer, o arquiteto e o artista plástico se integrem num processo de trabalho interdisciplinar. E sua formação deve ser ampla em informações tecnológicas e conhecimento dos valores

${ }^{32}$ TOZZI, Cláudio José. O processo de construção da imagem e sua aplicação, relação com o espaço urbano: arte no lugar da arquitetura no fazer de um artista plástico/ arquiteto. São Paulo: tese de doutoramento. Faculdade de Arquitetura e Urbanismo da Universidade de São Paulo, 2001. 
humanos, abrangendo questões que extrapolam o ato de criar ou de projetar um objeto isolado. ${ }^{33}$

\subsubsection{Questões da construção}

Com relação à construção, Tozzi citou a questão da dilatação dos materiais, vidro e concreto, serem diferentes e o caso de uma empena muito grande de um prédio exigir juntas de dilatação, as quais podem estar incorporadas no desenho do mosaico.

\subsubsection{O material}

O trabalho de Claudio Tozzi tem uma coerência com o mosaico por dois fatores. Um é porque o material, pastilha de vidro, é adequado para fazer arte em espaço público, por sua resistência e facilidade de manutenção. O outro é pela

${ }^{33}$ KIYOMURA, Leila; GIOVANNETTI, Bruno (Org.). Claudio Tozzi. São Paulo: Editora da Universidade de São Paulo e Imprensa Oficial do Estado, 2005. p. 203. 
coerência do mosaico com sua pintura que tem uma série de retículas e sobreposições de tons com a mesma cor.

\subsubsection{O processo de reprodução da imagem}

Como professor, Tozzi discutiu em aula ${ }^{34}$ a questão do processo de reprodução da imagem onde existe uma relação de mão dupla: fazemos o projeto (desenho), começamos o processo de produção (reprodução do desenho), percebemos variações de textura e cor no objeto resultante, voltamos ao projeto para fazer as adaptações que podemos vir a achar necessárias e repetimos o processo, tantas vezes quanto forem necessárias, até chegar ao objeto final. O objeto finalizado pode ter incorporado mais ou menos as alterações, de acordo com a vontade do artista e das possibilidades do mecanismo de produção.

\footnotetext{
${ }^{34}$ Programação Visual / Linguagens - Imagem Multiplicável do Módulo à Estrutura. Disciplina do $1^{\circ}$ ano de Arquitetura e Urbanismo em que a autora participou como monitora no segundo semestre de 2006.
} 


\section{Ao ser questionado sobre esse processo}

especificamente no caso dos seus mosaicos, Tozzi

respondeu que, ao transformar seus desenhos em mosaicos, também ocorrem surpresas e deu como exemplo o mosaico da Avenida Angélica, São Paulo, que foi projetado prevendo cerca de 30 tons de azul, mas, na hora de executar, foi constatado que havia no mercado cerca de 16 ou 18 tons. Por isso, o projeto teve de ser adaptado pelo artista; ele foi redimensionado em função do processo de produção da imagem em mosaico. 


\subsection{Teatro Cultura Artística}

Emiliano Di Cavalcanti

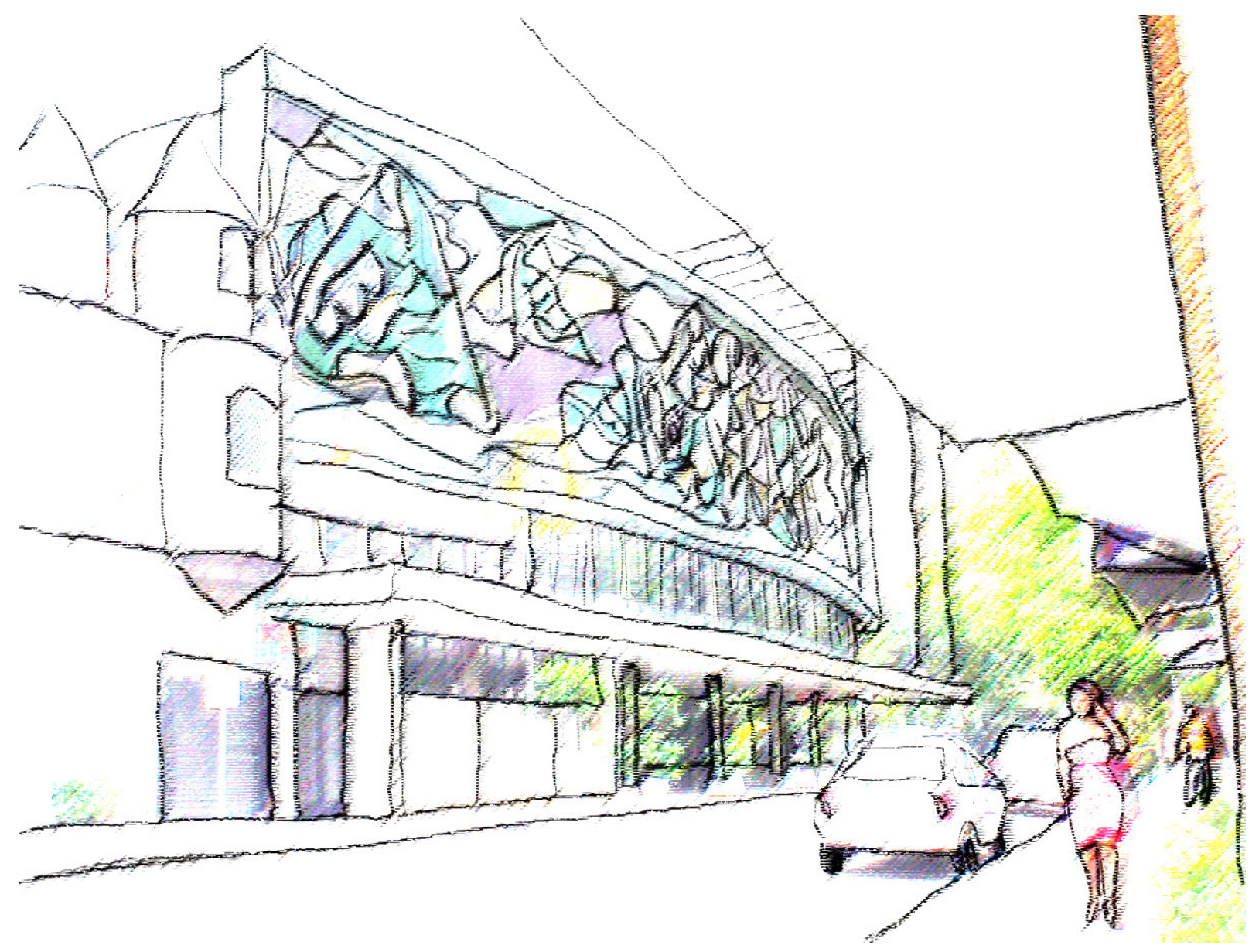

Figura 49 - Teatro Cultura Artística. (llustração da autora) 


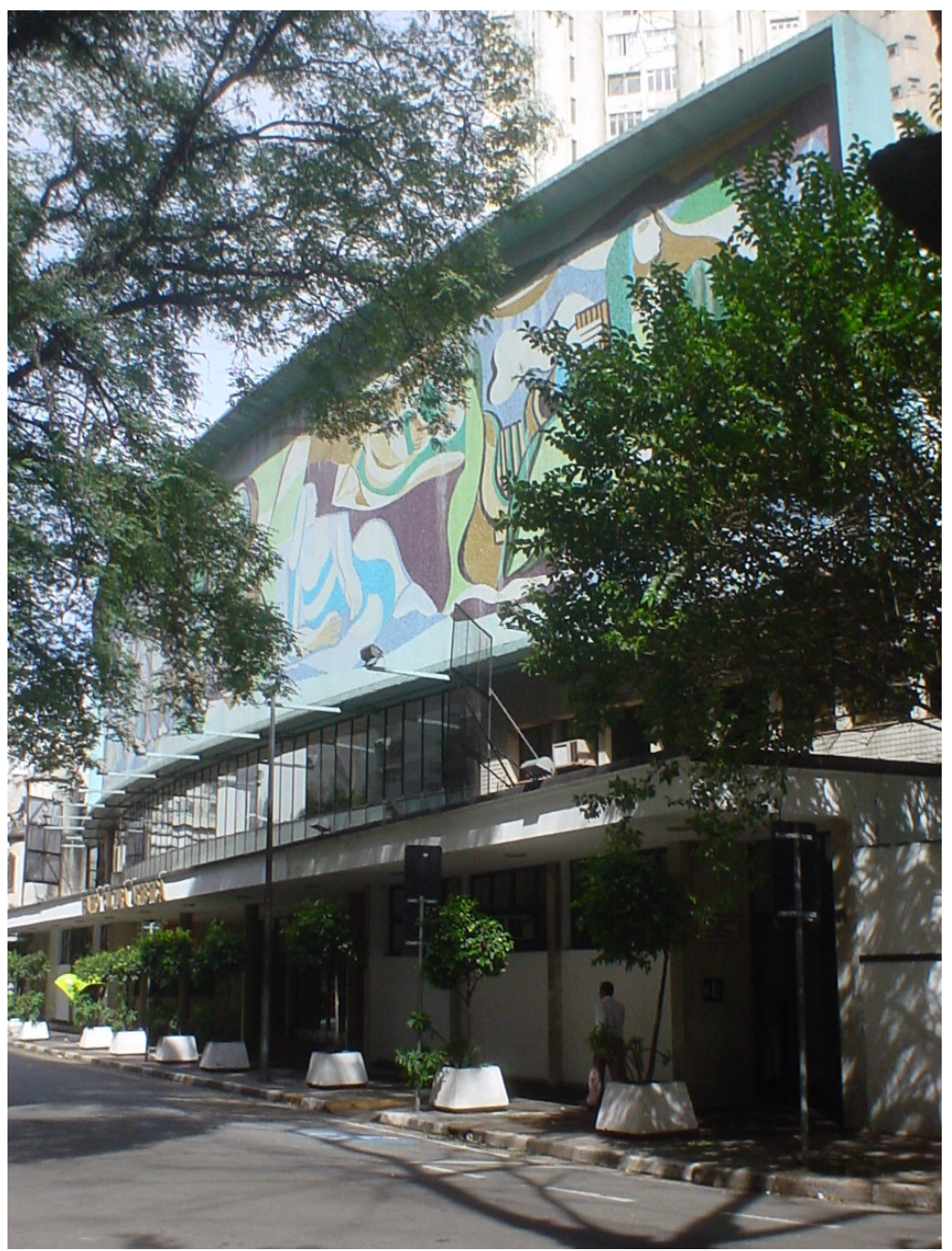

Figura 50 - Teatro Cultura Artística. (Foto da Autora)
A obra de Di Cavalcanti, escolhida através de concurso, (do qual também participou Roberto Burle Marx com uma proposta abstrata) demonstra um compromisso com sua integração com a arquitetura e com a cidade.

Suas figuras evidenciam o que se passa no interior do edifício e sua disposição segue a simetria do próprio edifício e o mural parece mais leve, uma vez que abaixo dele está uma caixilharia envidraçada.

A percepção deste mural foi comprometida devido à construção de edifícios que obstruíram completamente a sua visão a distância. Sendo visto apenas por partes, entre as copas das árvores, por aqueles que transitam pela calçada oposta. 
- Autor: Emiliano Di Cavalcanti (1897-1976).

- Arquiteto: Rino Levi.

- Endereço: Rua Nestor Pestana, 196, São Paulo, SP.

- Implantação: Ocupa todo o piso superior da fachada do edifício.

- Uso do edifício: teatro.

- Data: projeto 1942, execução 1947/49.

- Tema: Figurativo - artistas.

- Dimensões: 8x48m.

- Assinatura: canto inferior direito

- Transcrição da assinatura: E DI CAVALCANTI (abaixo da assinatura do artista, consta também: "EXECUÇÃO SA DECORAÇÕES EDIS").

- Data da avaliação: jan/2005.

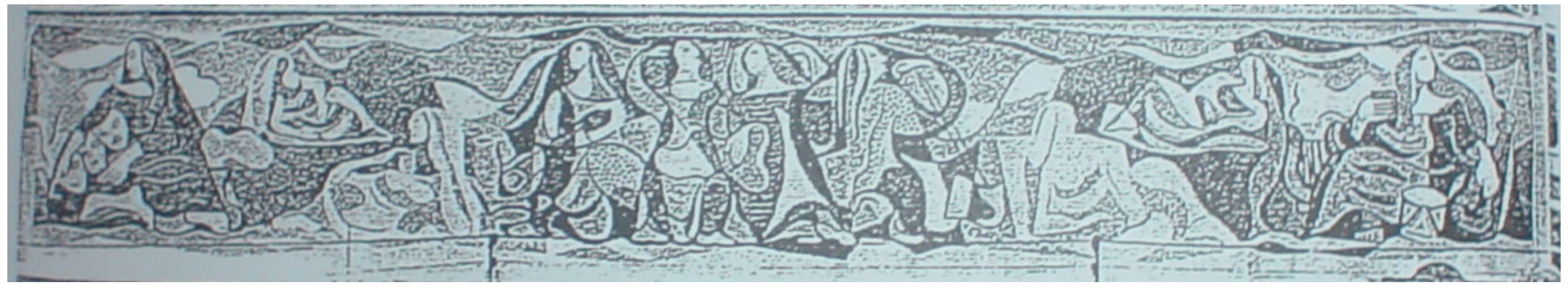

Figura 51 - Alegoria às Artes. (Reprodução a partir de foto antiga) 


\subsection{Residência Michel Abujamra} Clóvis Graciano

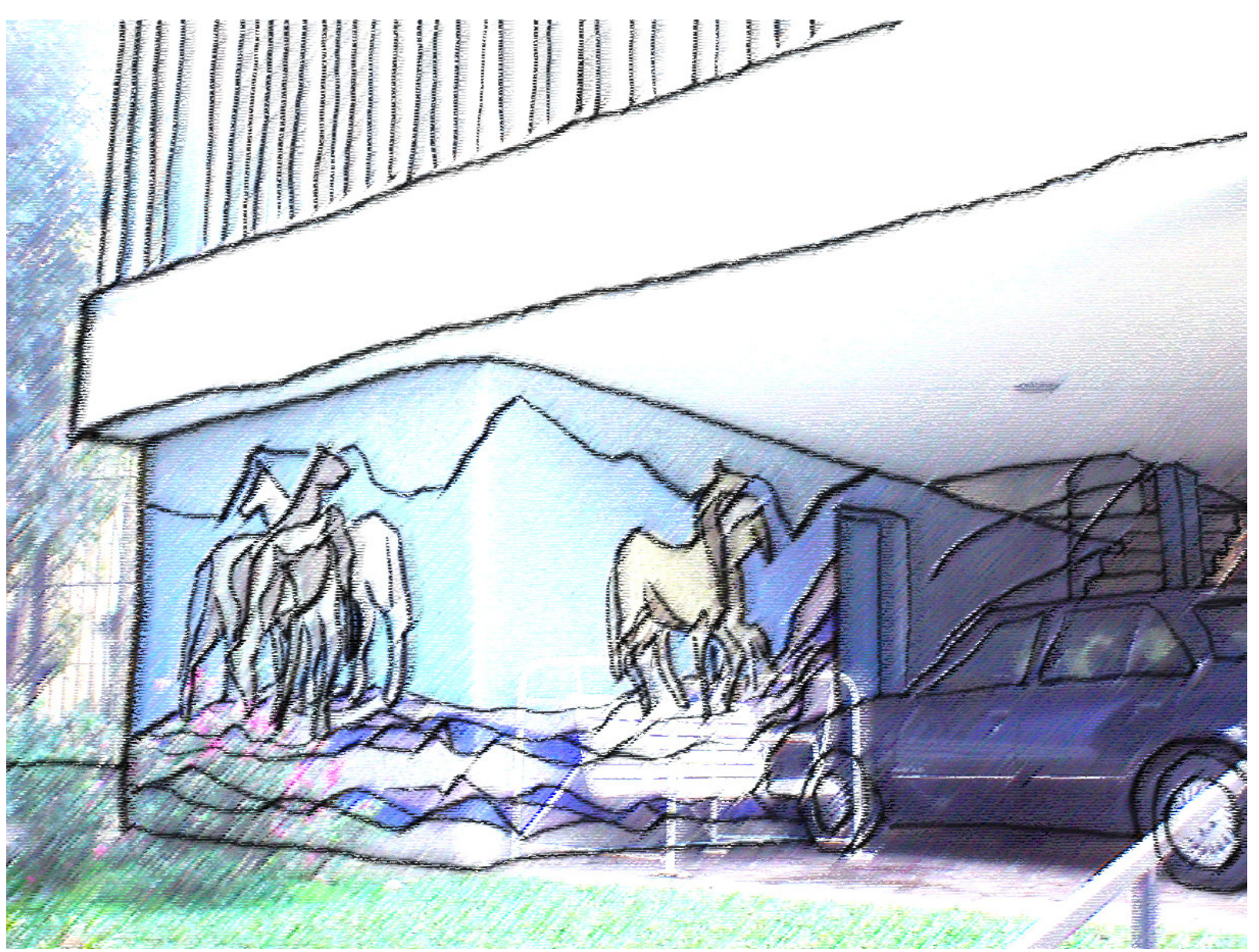

Figura 52 - Residência Michel Abujamra. (llustração da autora) 


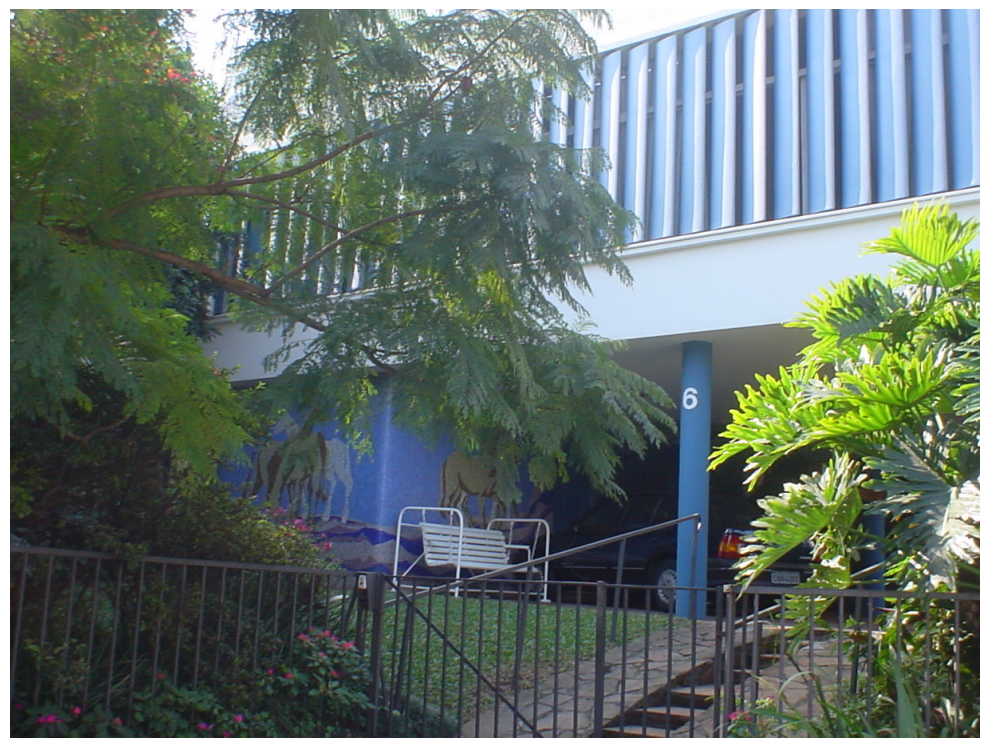

Figura 53 - Residência Michel Abujamra. (Foto da autora)
O mosaico reveste toda a parede no piso inferior de uma casa que tem a maior parte de seu volume suspenso. $O$ piso superior é um grande bloco, apoiado apenas em pilotis e algumas paredes.

A parede do piso inferior, sem uma intervenção, faria o grande volume acima dela aparentar mais pesado, anulando a leveza sugerida pelos pilotis. A composição figurativa com o fundo azul representando o céu sugere a continuidade do espaço aberto. Ao mesmo tempo, as figuras parecem suportar a casa elevada, os cavalos estão sobre um piso que é sugerido pelo desenho como um chão de pedra bastante sólido. E os próprios cavalos são animais que também nos remetem à idéia de solidez. 
- Autor: Clóvis Graciano (1907-1987).

- Título: Cavalos.

- Arquiteto: Oswaldo Corrêa Gonçalves.

- Endereço: Rua Tremembé, 6, São Paulo, SP.

- Implantação: duas paredes externas, fachada e garagem.

- Uso do edifício: residência.

- Data: 1951.

- Tema: cavalos.

- Dimensões: os dois têm 3x4m.

- Data da avaliação: jun/2006.
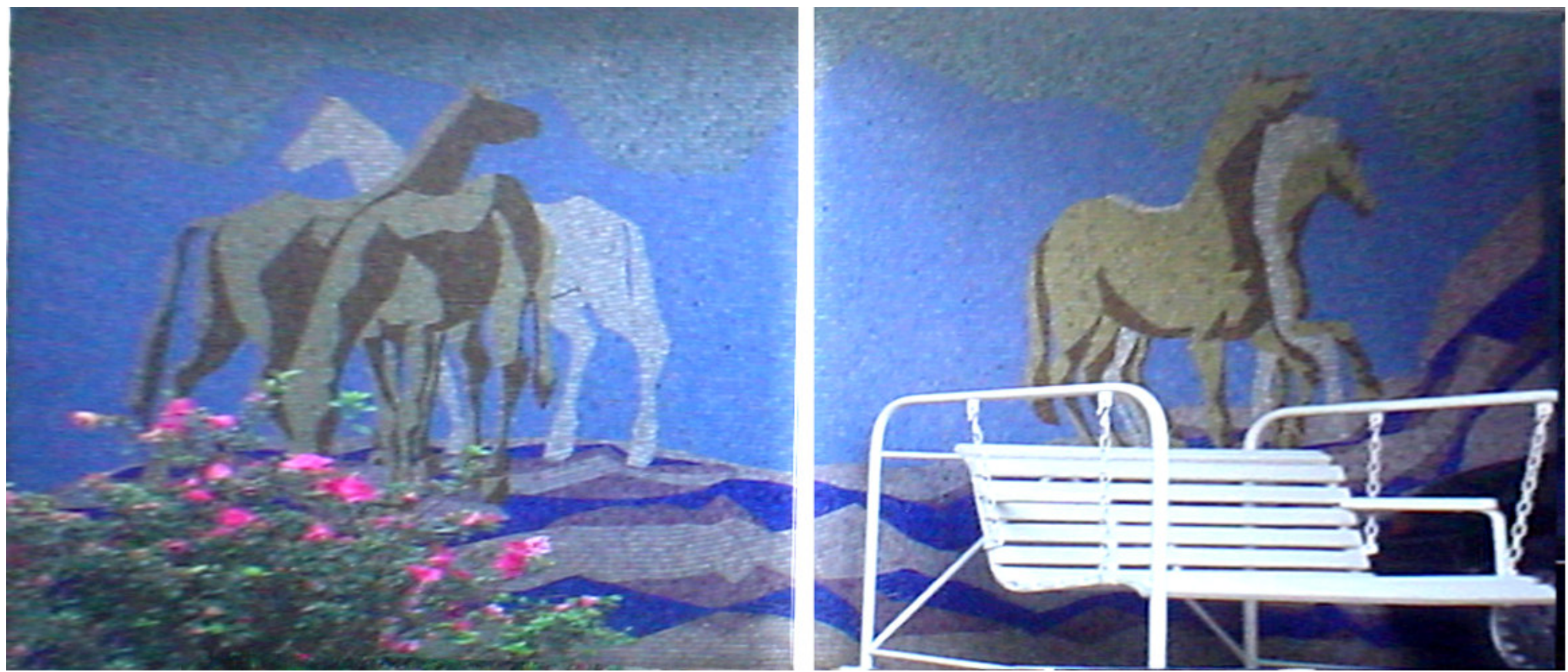

Figura 54 - Mosaico Cavalos de Clóvis Graciano. (Fotos da autora) 


\subsection{Hotel Jaraguá}

Emiliano Di Cavalcanti

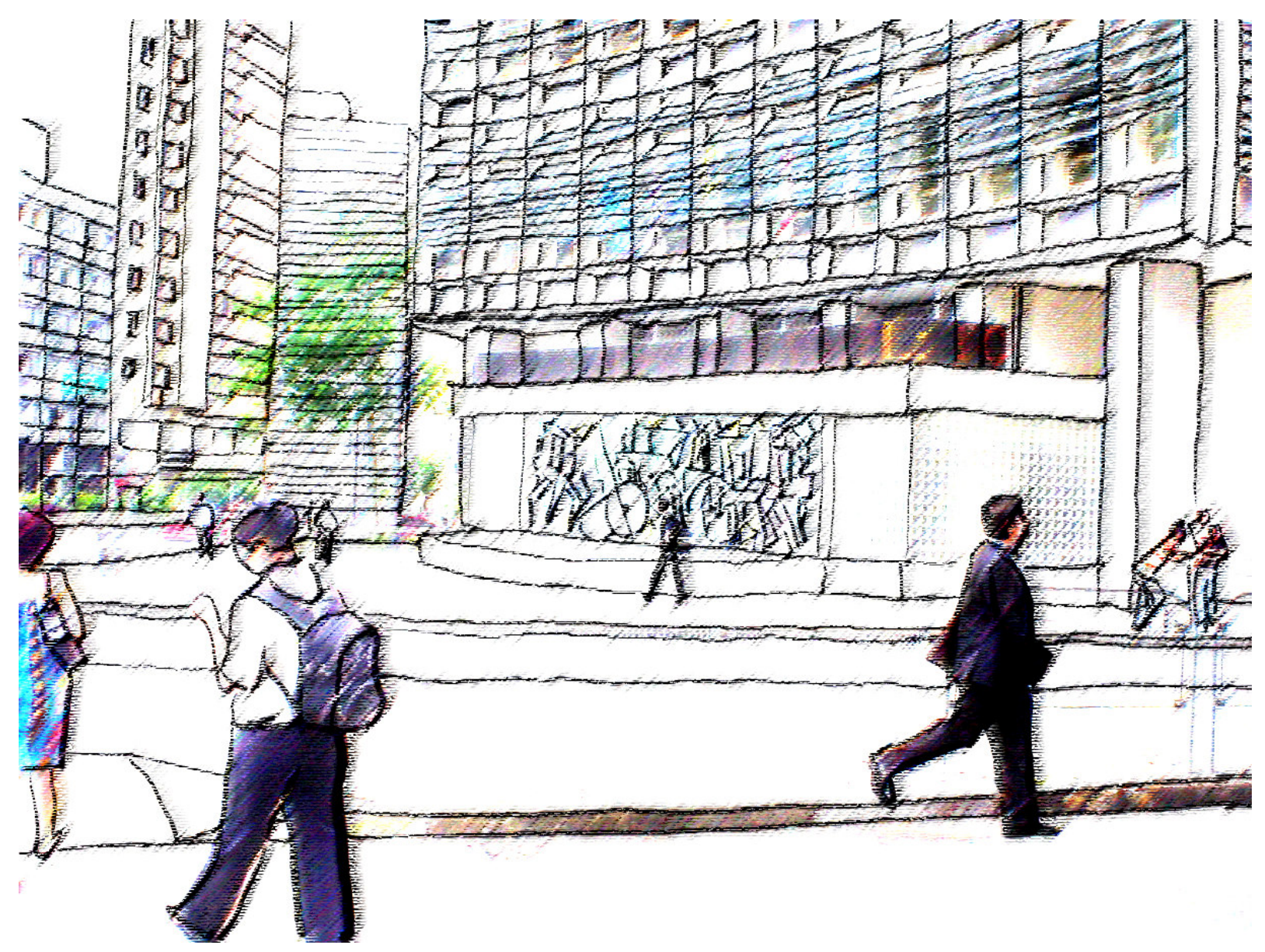

Figura 55 - Hotel Jaraguá. (llustração da autora) 


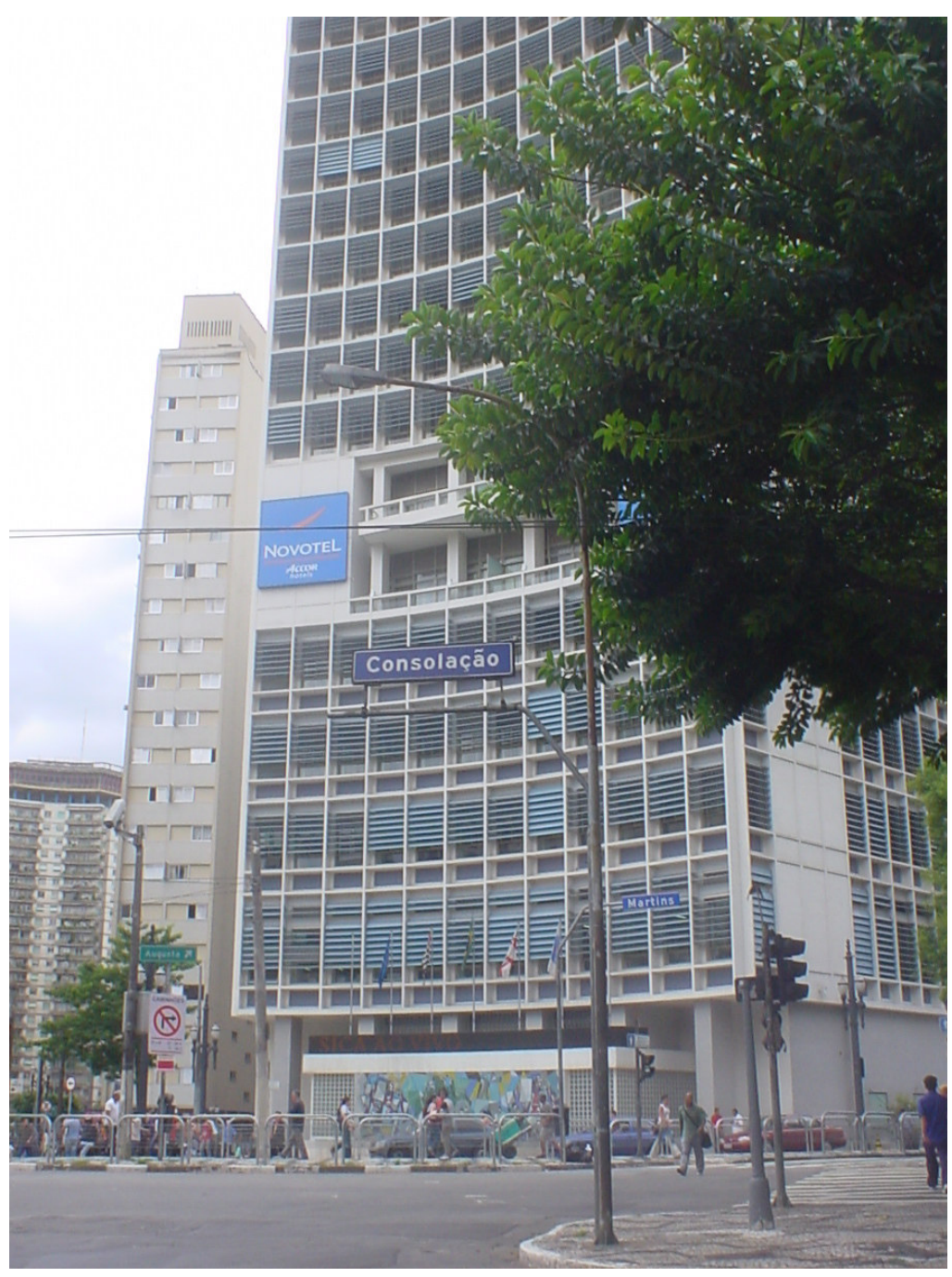

Figura 56 - Hotel Jaraguá. (Foto da autora)
O Hotel Jaraguá, inaugurado cinqüenta anos antes, na ocasião do quarto centenário de São Paulo, foi reinaugurado no novo endereço em 24 de janeiro de 2004 como uma das obras que integravam as ações de revitalização do centro de São Paulo. ${ }^{35}$

Este mosaico, que foi restaurado para a inauguração do hotel, é um dos trabalhos mais bem conservados da região central de São Paulo, o qual chama atenção também pelo fato de ser iluminado durante a noite. Percebe-se no local o empenho em conservar bem o edifício e suas obras de arte. (no interior há uma pintura mural de Clóvis Graciano).

Mais conhecido como Estadão, antigamente o edifício abrigava a sede de um jornal. O mural está localizado centralizado na esquina, no nível da rua. Ele mostra os trabalhadores da imprensa fazendo a redação, a impressão e a distribuição do jornal. Assim como no mural do Teatro Cultura Artística, também de Di Cavalcanti, havia no projeto a

${ }^{35}$ Notícia publicada na internet no dia 24 de janeiro de 2004: Antigo Hotel Jaraguá é reinaugurado no centro - Terra - SP 450 anos: http://sp450anos.terra.com.br/interna/0,,Ol259644-El2551,00.html 


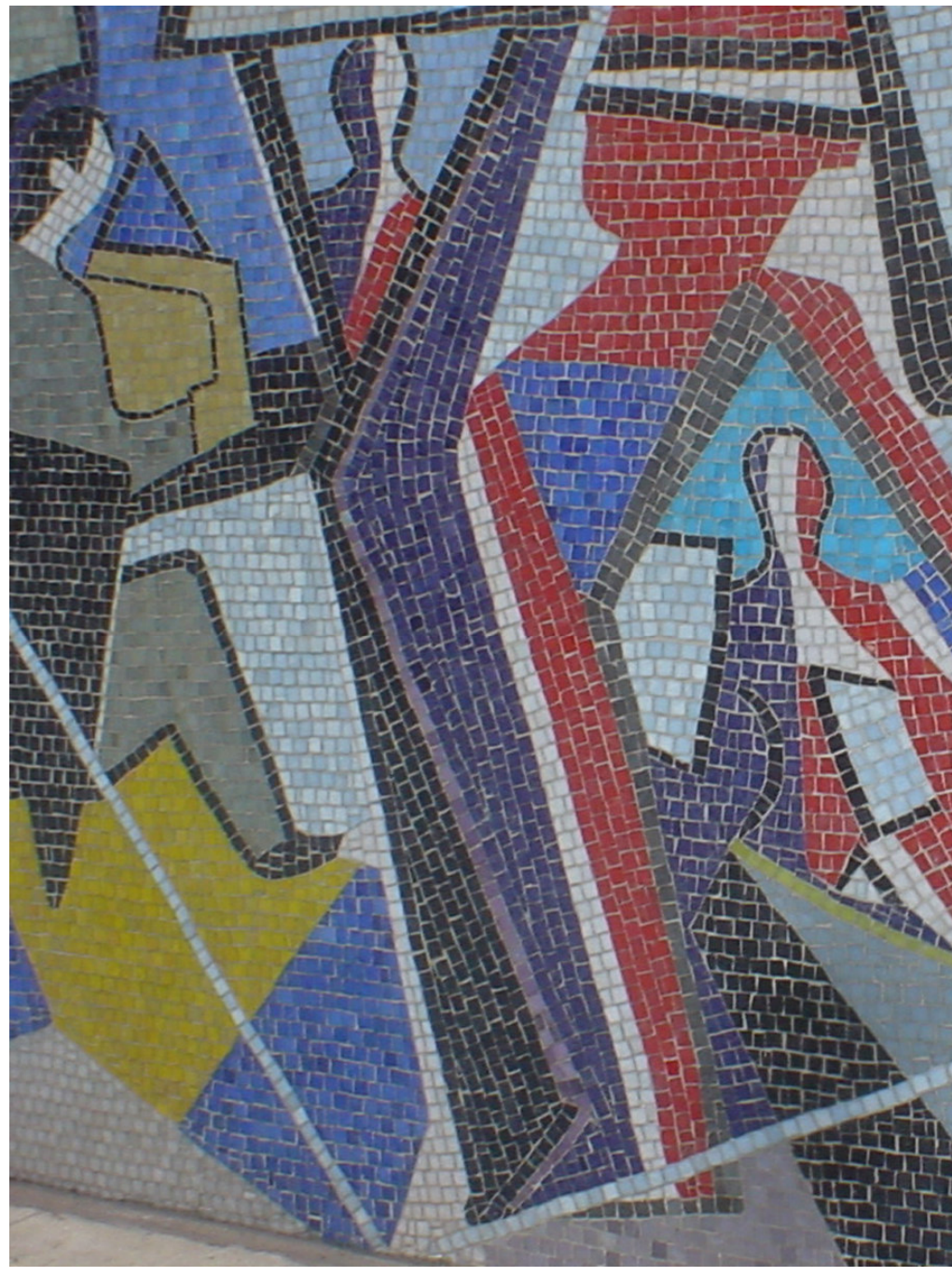

Figura 57 - Detalhe do mosaico de Di Cavalcanti no Hotel Jaraguá. (Foto da autora) intenção de comunicar ao transeunte o que se passava no interior do edifício.

As figuras em tamanho maior nos extremos, trabalhadores distribuindo o jornal, e menor no centro, trabalhadores fazendo o jornal, além de darem simetria ao desenho, sugerem uma perspectiva que acompanha a parede curva que se encontra acima do mural.

Assim como muitas outras obras do mesmo período, apesar de esta tratar-se de uma composição rica em detalhes, não há mistura de cor nas áreas delimitadas. 
- Autor: Emiliano Di Cavalcanti (1897-1976).

- Arquitetos: Jacques Pilon e Adolf Franz Heep.

- Endereço: Rua Major Quedinho, 28, São Paulo, SP.

- Implantação: na esquina das ruas Major Quedinho e

Martins Fontes, numa parede externa.

- Uso do edifício: Hotel Jaraguá, originalmente, Edifício "O

Estado de São Paulo".

- Data: projeto 1946, execução 1952.

- Tema: Figurativo - trabalhadores da imprensa.

- Dimensões: 2,70 x 9,5m.

- Assinatura: canto inferior direito.

- Transcrição da assinatura: E DI CAVALCANTI.

- Data da avaliação: jan/2005.

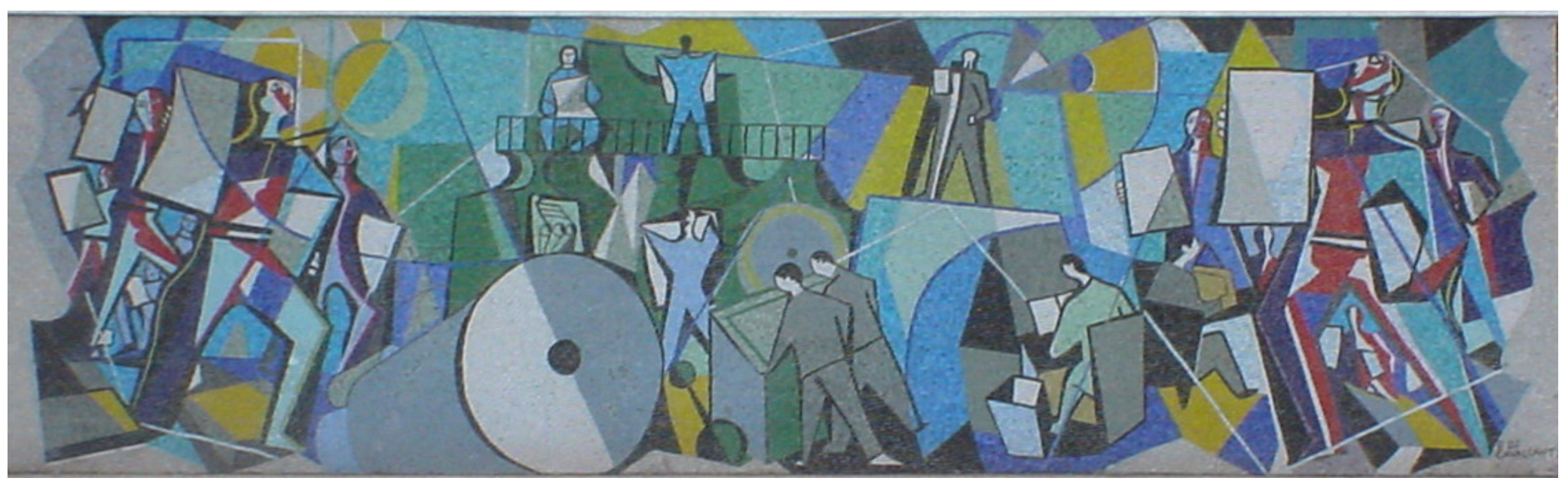

Figura 58 - Mosaico de Di Cavalcanti no Hotel Jaraguá. (Foto da autora) 


\subsection{Residência Olívio Gomes} Roberto Burle Marx

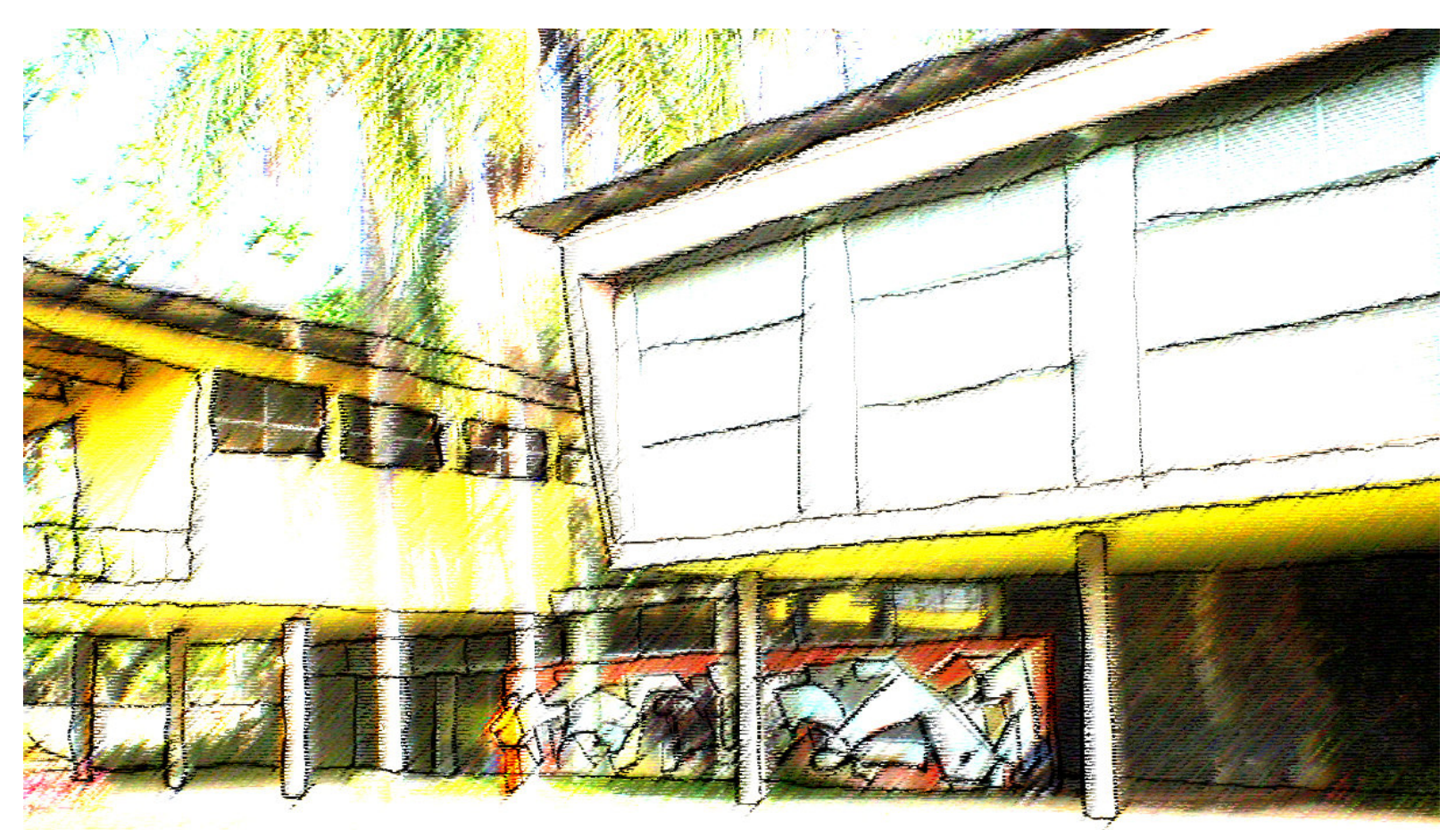

Figura 59 - Residência Olívio Gomes. (llustração da autora) 


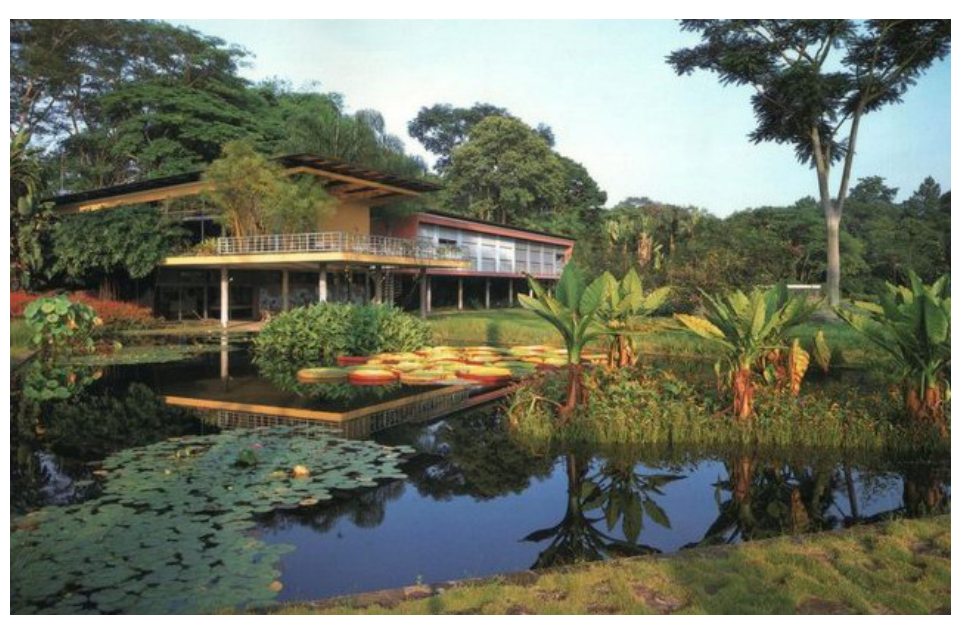

Figura 60 - Residência Olívio Gomes e jardim. (Foto de Michael Moran. Fonte: ADAMS, William Howard. Roberto Burle Marx: The unnatural art of the garden. New York: The Museum of Modern Art, 1991.)
Projetada por Rino Levi e Roberto de Cerqueira César, a residência Olívio Gomes, em São José dos Campos, não tem contato com a rua. Por isso, a fachada privilegiada da casa fica voltada para os fundos, onde há um lago e um jardim exuberante com projeto de paisagismo de Roberto Burle Marx. Na ocasião, a obra foi apresentada na Bienal de Arquitetura em São Paulo (1951), e foi amplamente divulgada.

Atualmente a propriedade, que, além da residência, abrigava a Tecelagem Parahyba, pertence à Cidade de São José dos Campos que a transformou em um parque. A casa permanece fechada durante a maior parte do tempo, abrigando, ocasionalmente, uma exposição, mas pode ser contemplada pelos freqüentadores do parque.

Sobre pilotis, a casa parece flutuar sobre a paisagem, por pouco, não se percebe que existe uma grande sala de jogos no piso inferior. Ali estão os mosaicos do paisagista. Eles estão nas duas faces da mesma parede, na face externa, voltada para o jardim, um mosaico vermelho com um pouco de azul, e na interna, voltada para a sala de jogos, 


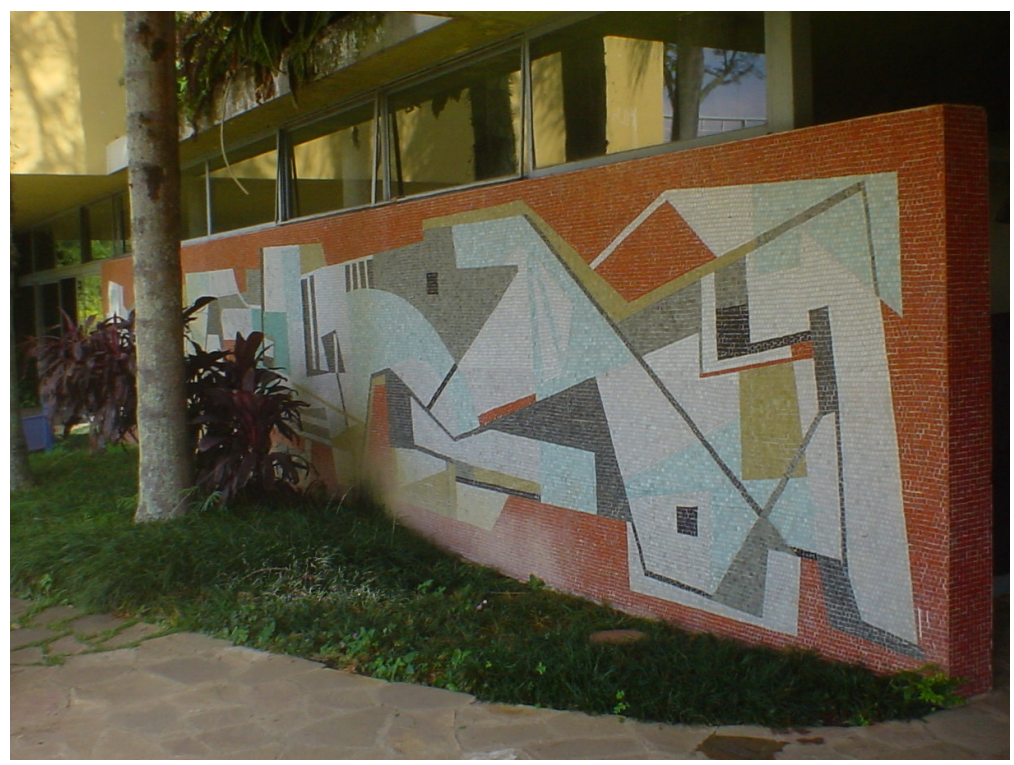

Figura 61 - Mosaico voltado ao jardim da Residência Olívio Gomes. (Foto da autora) outro, azul com um pouco de vermelho. Eles parecem

completamente soltos, porque esta parede não tem contato com as outras paredes da casa. Quase toda a parede é cercada por vidro pelos lados e por cima, até o teto, e parte dela se projeta além da sala de jogos.

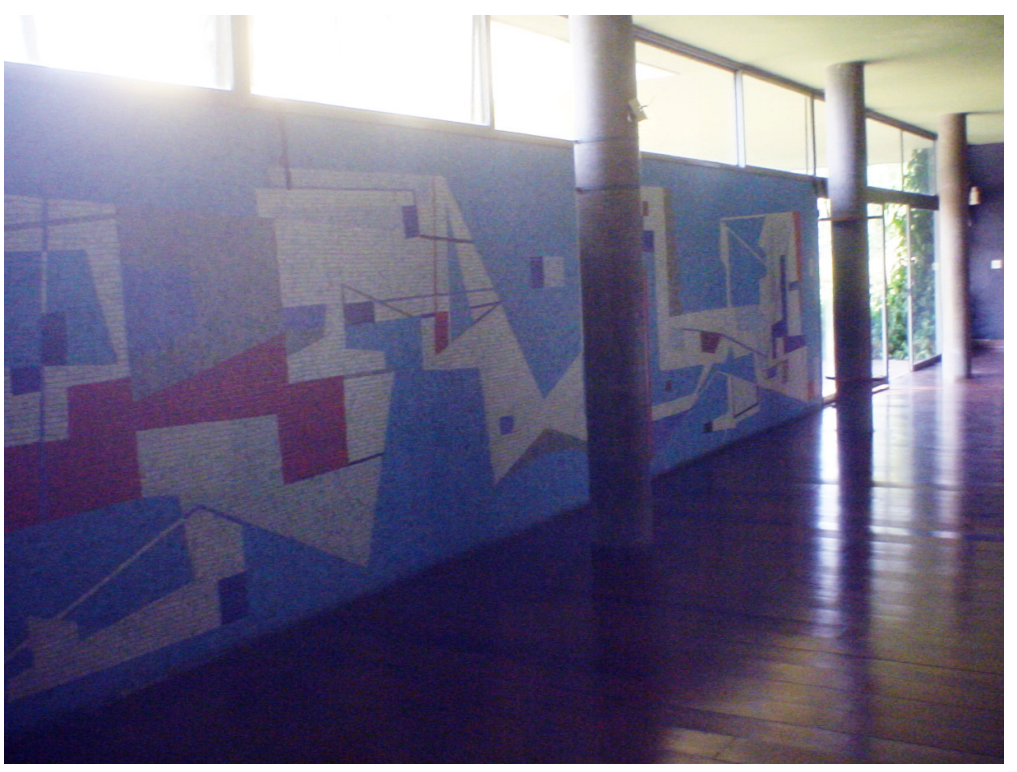

Figura 62 - Mosaico voltado à sala de jogos da Residência Olívio Gomes. (Foto da autora) 


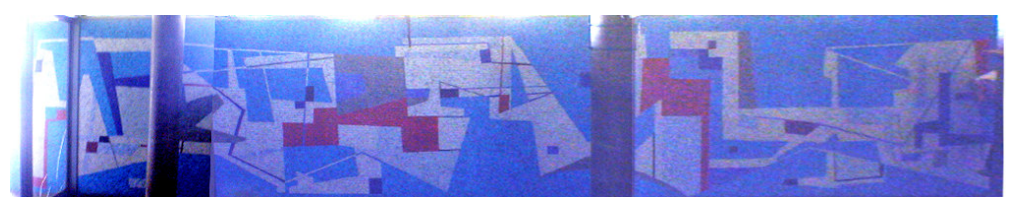

Figura 63 - Mosaico de Roberto Burle Marx na sala de jogos da Residência Olívio Gomes. (Foto da autora)
- Autor Roberto Burle Marx (1909-1994).

- Arquiteto: Rino Levi e Roberto de Cerqueira César.

- Endereço: Parque Municipal Roberto Burle Marx, Av.

Olivio Gomes, s/nº São José dos Campos, SP.

- Implantação: dois murais implantados em uma mesma parede da casa, um interno, na sala de jogos, outro externo, voltado ao jardim.

- Uso do edifício: originalmente residência, atualmente permanece a maior parte do tempo sem uso.

- Data: mosaico sem data registrada, mas a casa teve seu projeto em 1949 e construção em 1951/53.

- Tema: abstrato geométrico.

- Dimensões: dois mosaicos com 2,24x12,67m.

- Assinatura: canto inferior direito do mural interno.

- Transcrição da assinatura: ROBERTO BURLE MARX.

- Data da avaliação: abr/2006.
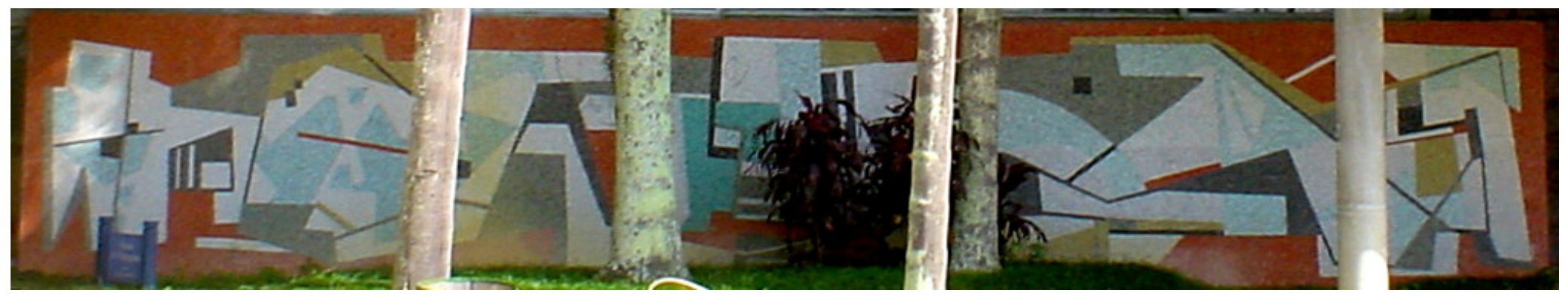

Figura 64 - Mosaico de Roberto Burle Marx na parede externa da Residência Olívio Gomes. (Foto da autora) 


\subsection{Centro Empresarial Itaúsa}

Cândido Portinari

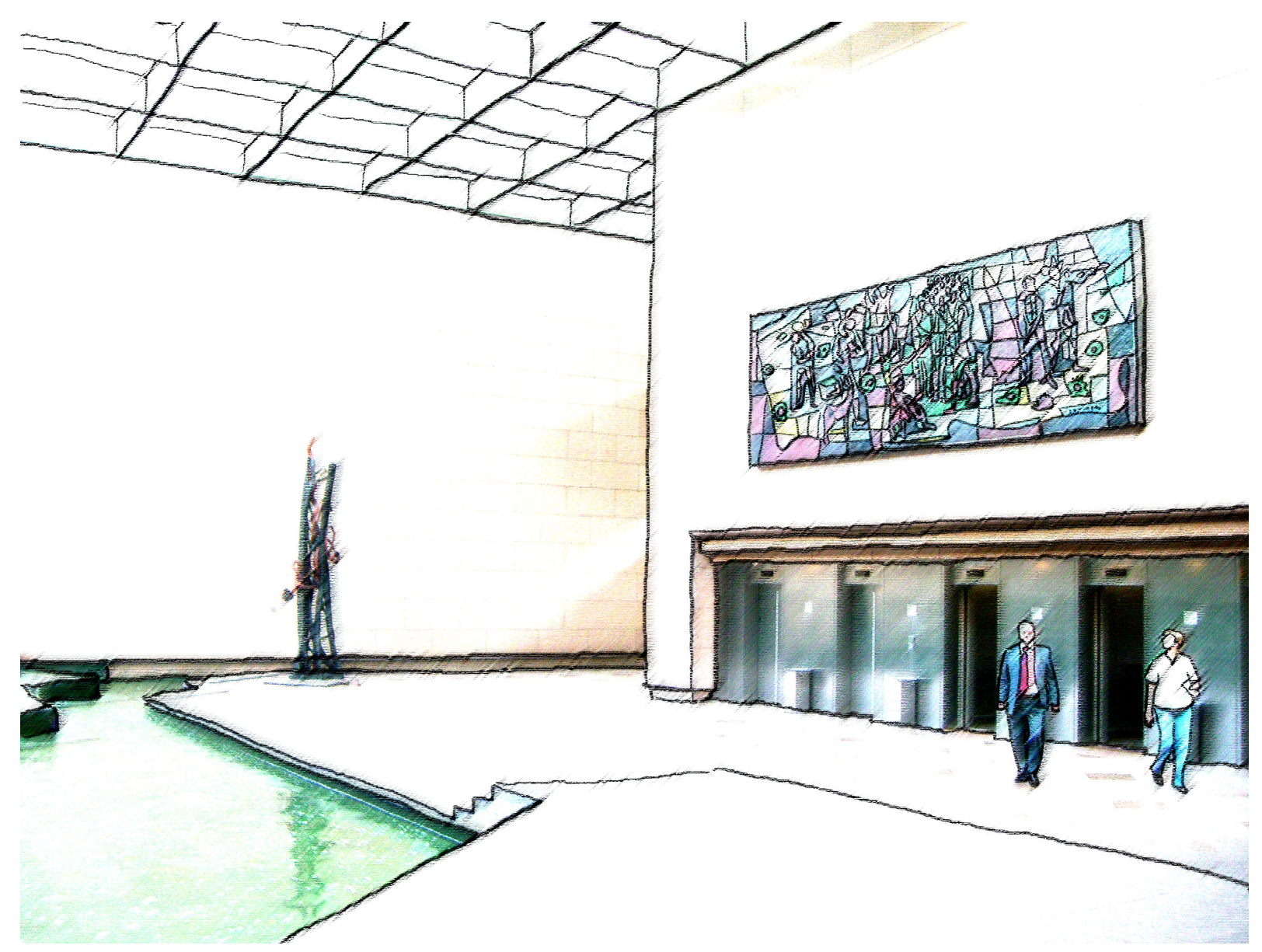

Figura 65 - Ambiente com mosaico de Portinari no Centro Empresarial Itaúsa. (Ilustração da autora) 


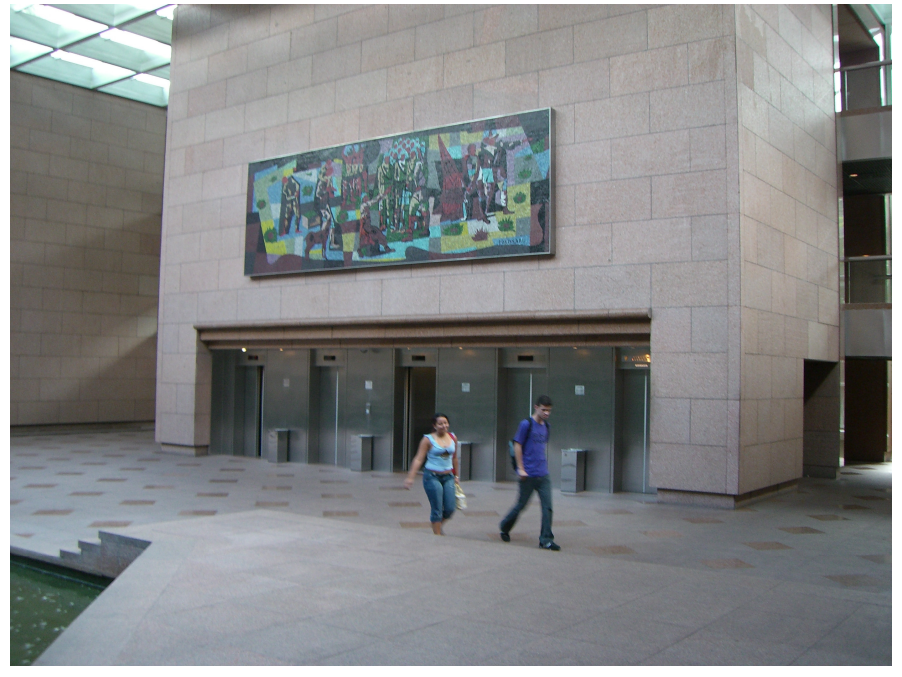

Figura 66 - Mosaico de Portinari no ambiente amplo onde está instalado atualmente. (Foto da autora)

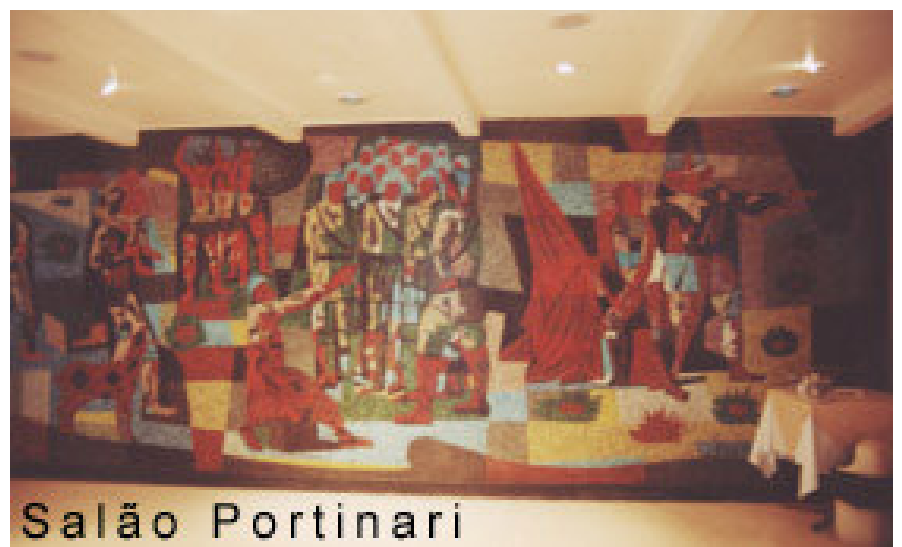

Figura 67 - Mosaico em seu espaço original. (Fonte: www.hotelcomodoro.com.br/convsala.htm)
Os Bandeirantes de Cândido Portinari é um caso raro de mosaico que muda de endereço. Depois de pouco mais de cinqüenta anos em uma parede do restaurante do Hotel Comodoro, no Centro de São Paulo, em 2004 o mosaico foi retirado, transformado em um painel avulso, restaurado, exposto no espaço cultural da BM\&F e, finalmente, mas não se pode dizer se definitivamente, foi colocado em uma parede da Torre de Vidro do Centro Empresarial Itaúsa.

Retirar um mosaico de um lugar é muito dispendioso, só compensando se tiver um valor muito alto, como no caso deste, avaliado na ocasião da retirada em 2 milhões de reais. O painel avulso compreende não só o mosaico, mas também a própria parede que foi retirada do hotel; ele tem $250 \times 765 \mathrm{~cm}, 15 \mathrm{~cm}$ de espessura e cerca de $800 \mathrm{~kg}$.

Anteriormente, no hotel, o mosaico ocupava toda a parede, do piso ao teto, e estava ao alcance das mãos dos freqüentadores do pequeno restaurante com capacidade para cinqüenta pessoas. Atualmente, na parede acima de cinco elevadores, em um ambiente amplo e com farta iluminação 


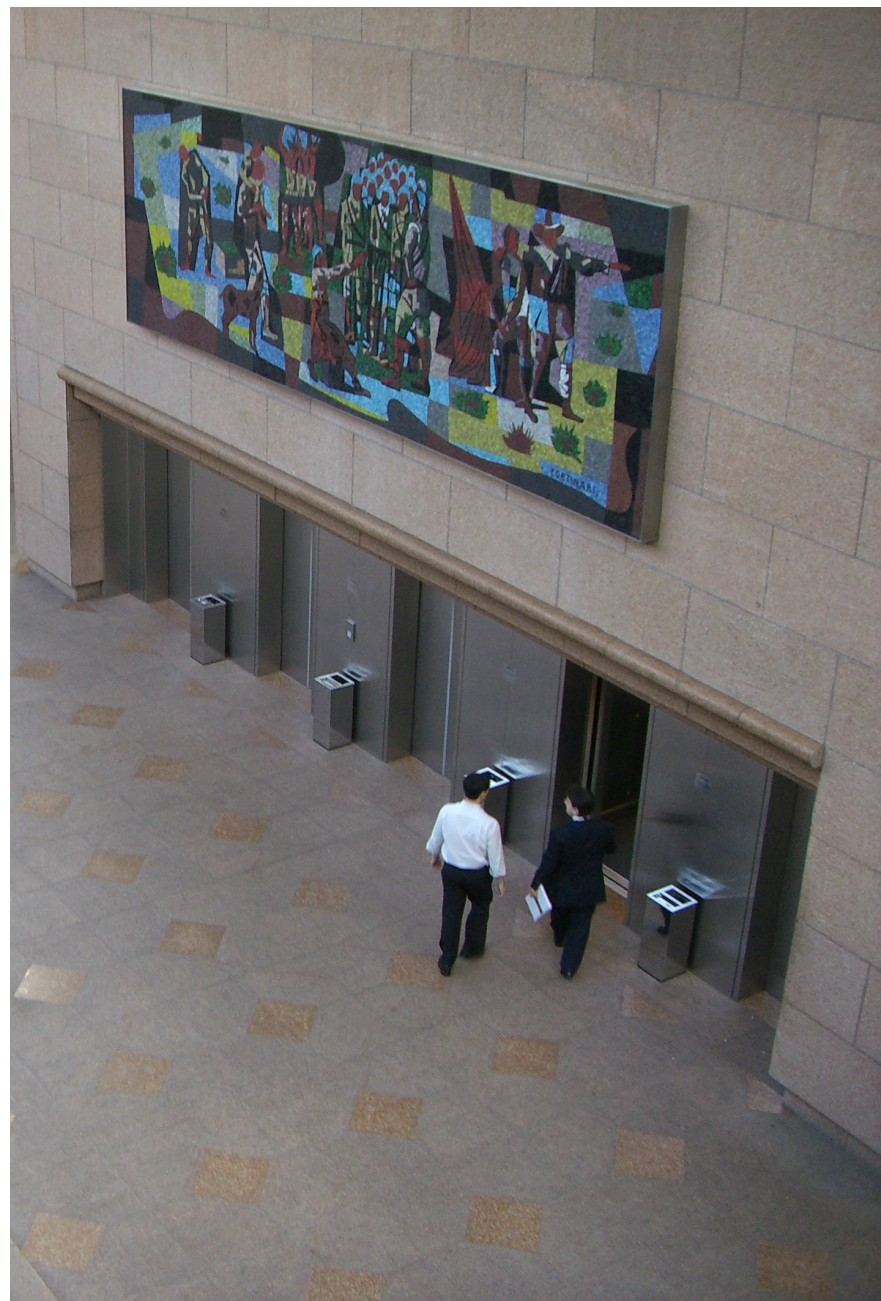

Figura 68 - Mosaico de Portinari visto a partir de um piso superior. (Foto da autora) natural, nem parece ser tão pesado quanto aparenta em registro da época em que estava no restaurante.

No período vespertino, a luz natural que penetra o ambiente através da cobertura é refletida diretamente para os olhos do observador no piso dos elevadores, prejudicando a visualização das cores, mas o mosaico pode ser observado sem essa distorção de cima para baixo pelo seu lado esquerdo. 
- Autor: Cândido Portinari (19031962).

- Título: Os Bandeirantes.

- Superintendência de Arquitetura do Grupo Itaú em parceria com Aflalo \& Gasperini.

- Endereço: Praça Alfredo Egydio de Souza Aranha, 100, São Paulo, SP.

- Implantação: parede acima dos elevadores.

- Uso do edifício: edifício administrativo de banco.

- Data: 1953.

- Tema: bandeirantes.

- Dimensões: 250x765cm

- Assinatura: canto inferior direito

- Transcrição da assinatura: PORTINARI

- Data da avaliação: dez/2006.

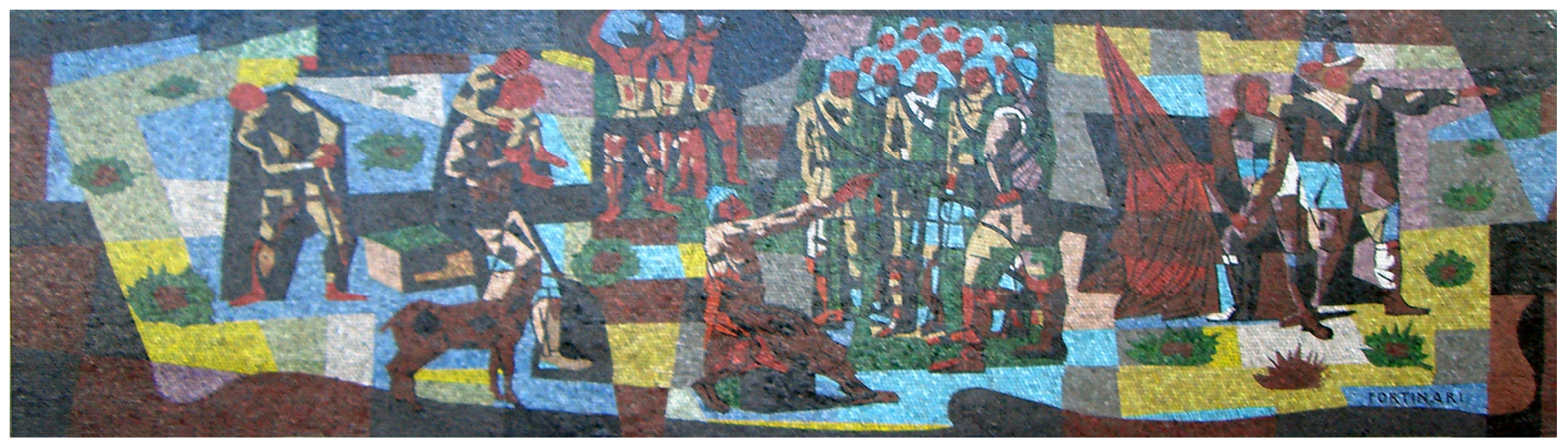

Figura 69 - Mosaico Os Bandeirantes de Cândido Portinari. (Foto da autora) 


\subsection{Edifício Montreal} Emiliano Di Cavalcanti

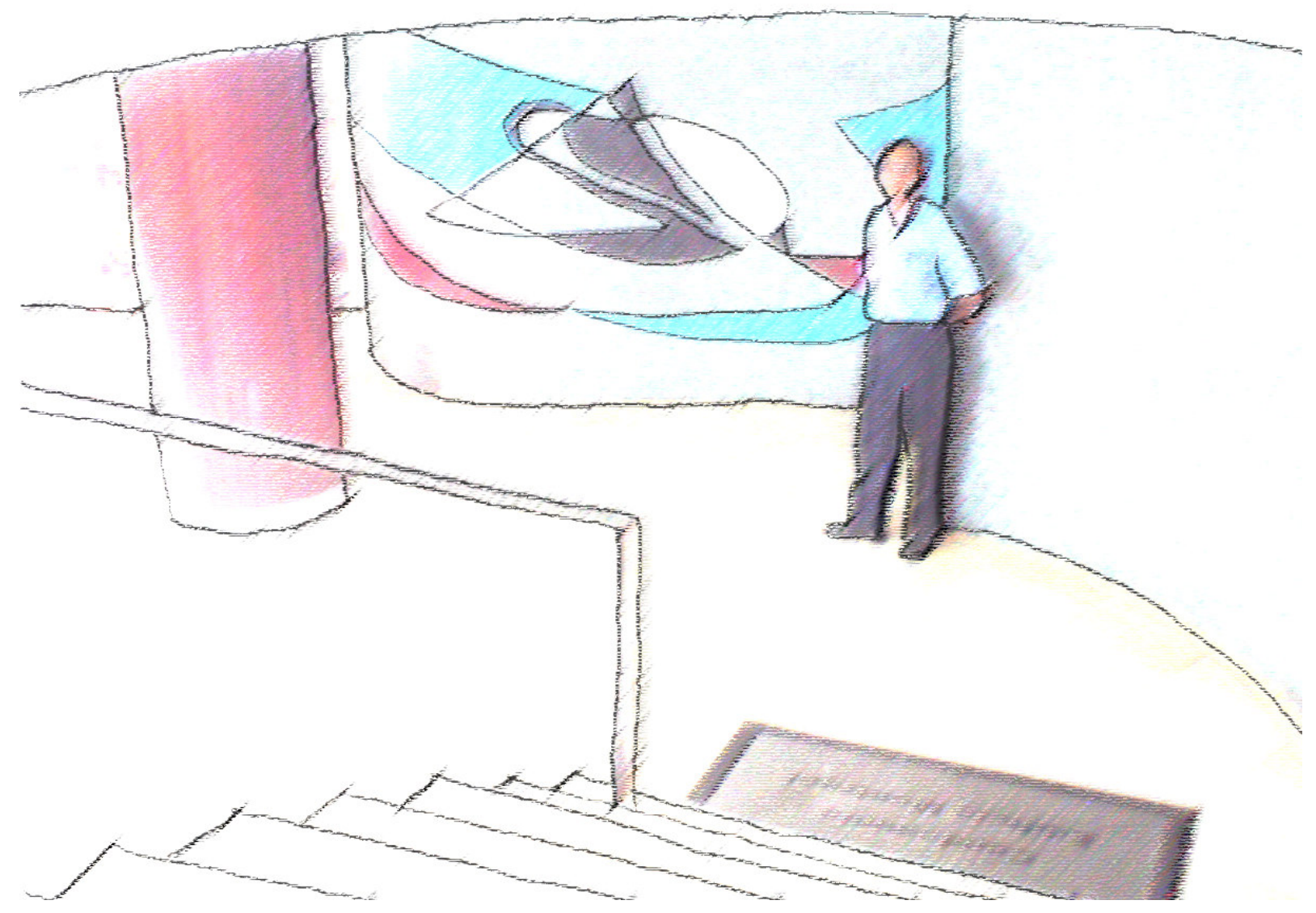

Figura 70 - Vista a partir de um dos acessos do Edifício Montreal. (Ilustração da autora) 


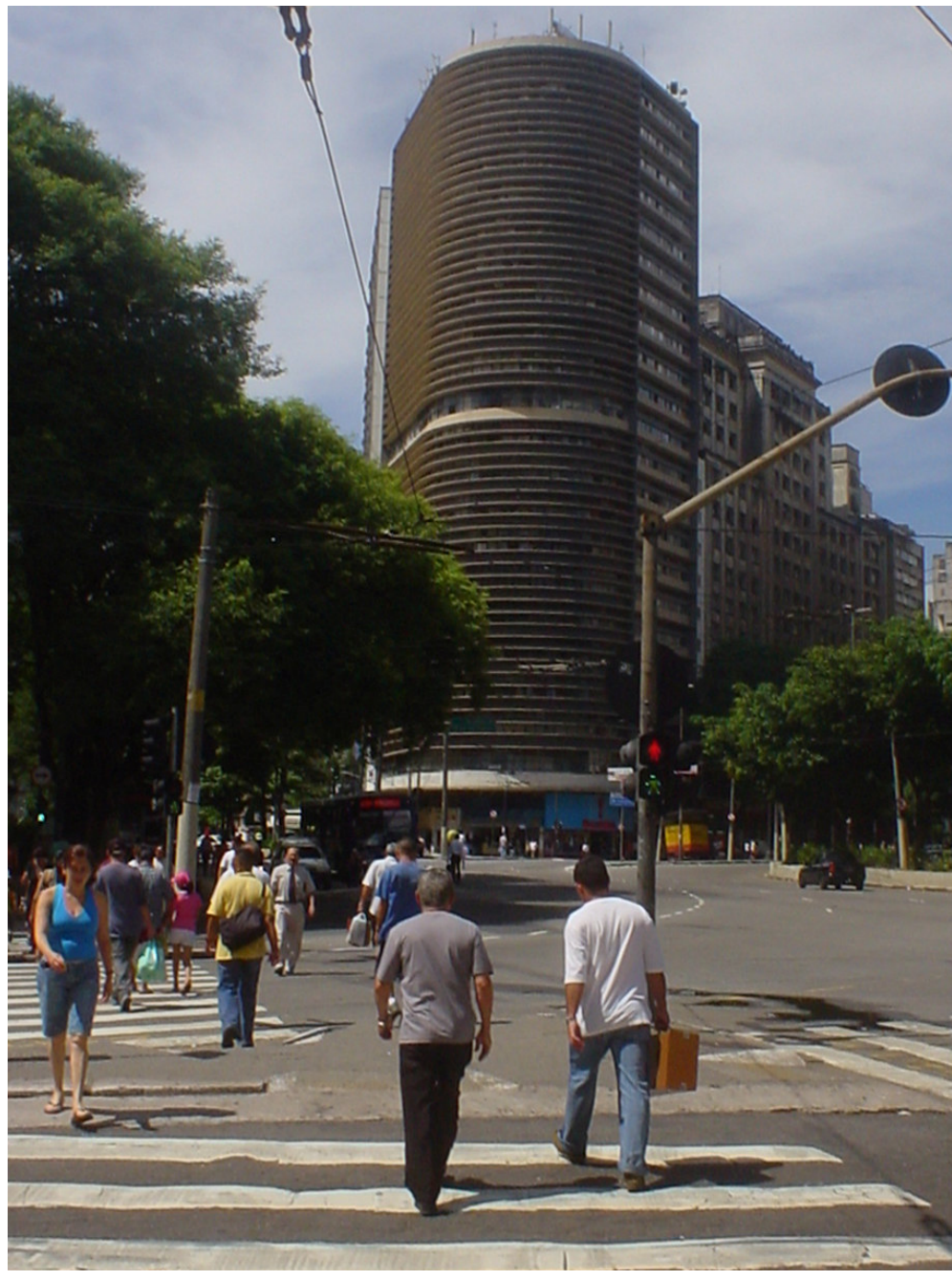

Figura 71 - Edifício Montreal. (Foto da autora)
O edifício residencial Montreal, de Oscar Niemeyer, situado em um cruzamento, é caracterizado pelas curvas, desde a fachada que acompanha a curva da esquina até as paredes internas. A composição de três mosaicos com poucas cores, azul, vermelho, branco e preto, está integrada ao edifício com as formas sinuosas fluindo pelo espaço determinado por paredes também sinuosas.

Onde o mosaico termina, o revestimento de pastilhas cinzas, fundo do desenho, continua em praticamente todo o ambiente como material de construção. Tudo isso mantém uma unidade. Ao observar o ambiente em uma fotografia antiga, foi contatado que o piso original também era revestido com pastilhas, mas não foi possível identificar a sua cor.

Nesta obra de Di Cavalcanti, é possível perceber claramente que não só o mosaico pode transformar o espaço, mas o espaço também pode transformar o mosaico. Para quem circula no Edifício Montreal, parece que existem três mosaicos diferentes, porém, o da parede interna e o do acesso pela Avenida Cásper Líbero são idênticos. Como os três não podem ser vistos simultaneamente, e a forma das 


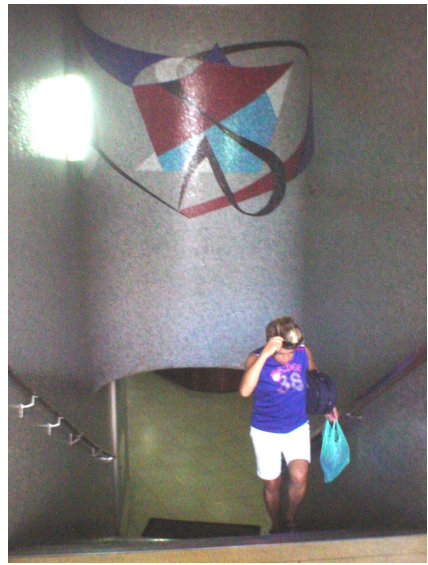

Figura 72 - Escada de acesso ao Edifício Montreal pela Av. Ipiranga. (Foto da autora)

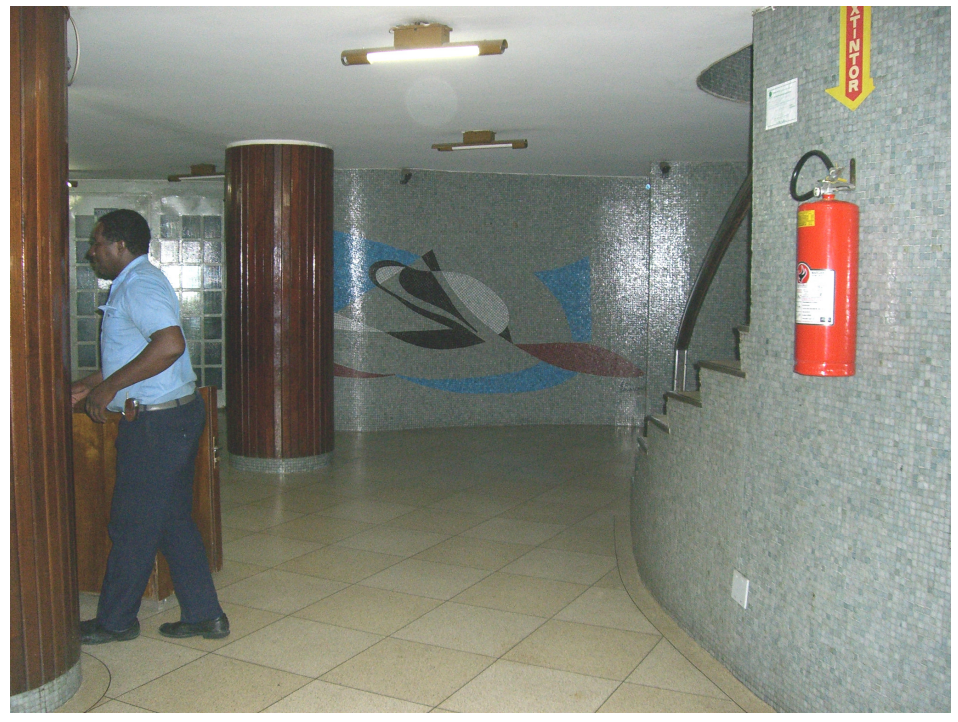

Figura 73 - Área interna do Edifício Montreal. (Foto da autora) paredes onde estão aplicados varia (uma côncava e outra convexa), isso dificilmente é percebido. A própria autora só veio a constatar que dois deles são idênticos ao olhar as fotografias dos três, lado a lado.

Maria Cecília França Lourenço descreveu os dois mosaicos sem citar que são idênticos, primeiro o da escada da Avenida Cásper Libero: "Trabalha com formas sinuosas em expansão (...) em que a composição foi realizada acompanhando o percurso do observador (...)." e o outro: "No saguão as formas são mais horizontalizadas, como numa pausa, o que contrasta com as entradas, onde parecem ritmadas pelo vento, pela luz e pelo mover-se de quem passa. ${ }^{\text {'36 }}$

\footnotetext{
${ }^{36}$ LOURENÇO, Maria Cecília França. Operários da Modernidade. São Paulo: Hucitec/Edusp, 1995. p. 270.
} 


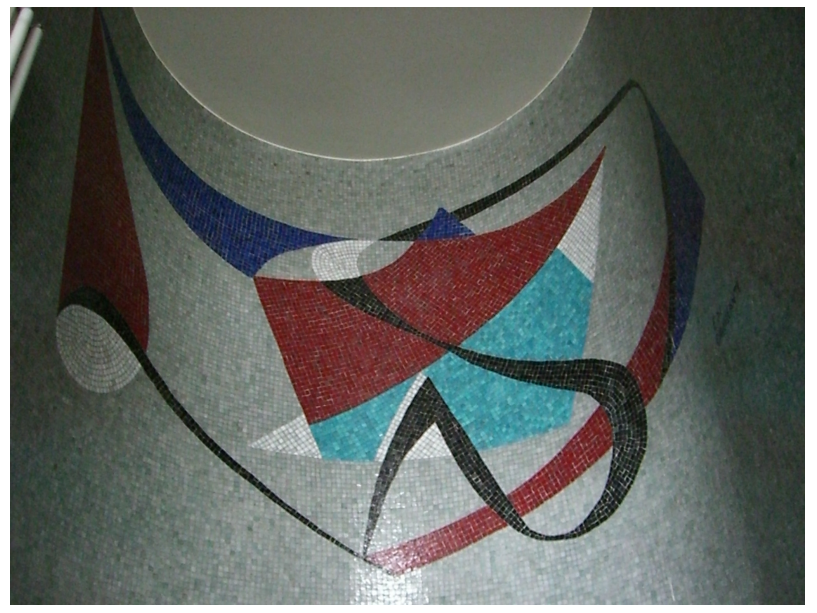

Figura 74 - Mosaico acima da escada da Av. Ipiranga. (Foto de Peter Caplan)

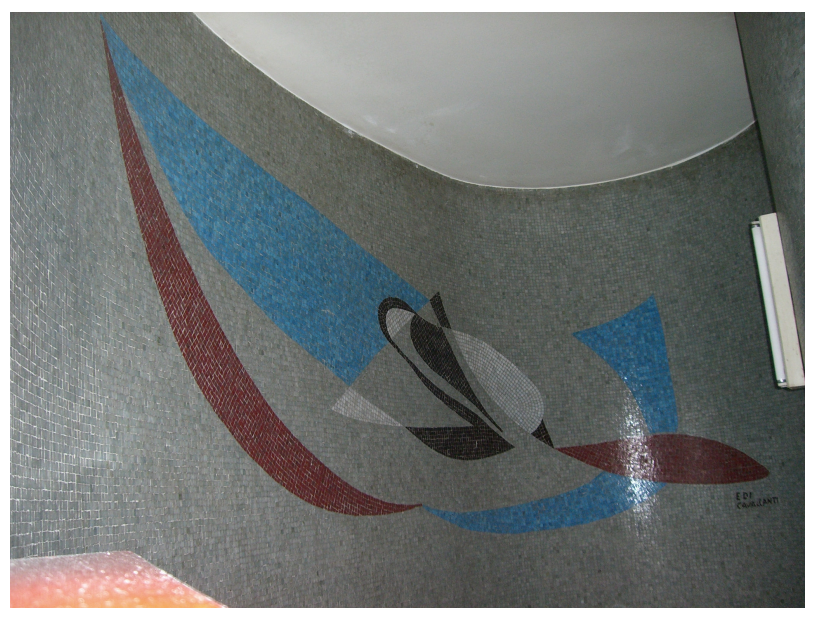

Figura 75 - Mosaico acima da escada da Av. Cásper Líbero. (Foto de Peter Caplan)
- Autor: Emiliano Di Cavalcanti (1897-1976).

- Arquiteto: Oscar Niemeyer.

- Endereço: Avenida Ipiranga, 1284, São Paulo, SP.

- Implantação: são três mosaicos, sobre paredes curvas, dois deles instalados acima das escadas de acesso e um no interior.

- Uso do edifício: residencial.

- Data: 1954.

- Tema: abstrato.

- Dimensões: diversas.

- Assinatura: canto inferior direito.

- Transcrição da assinatura: E DI CAVALCANTI.

- Execução: Vidrotil.

- Data da avaliação: jan/2005.

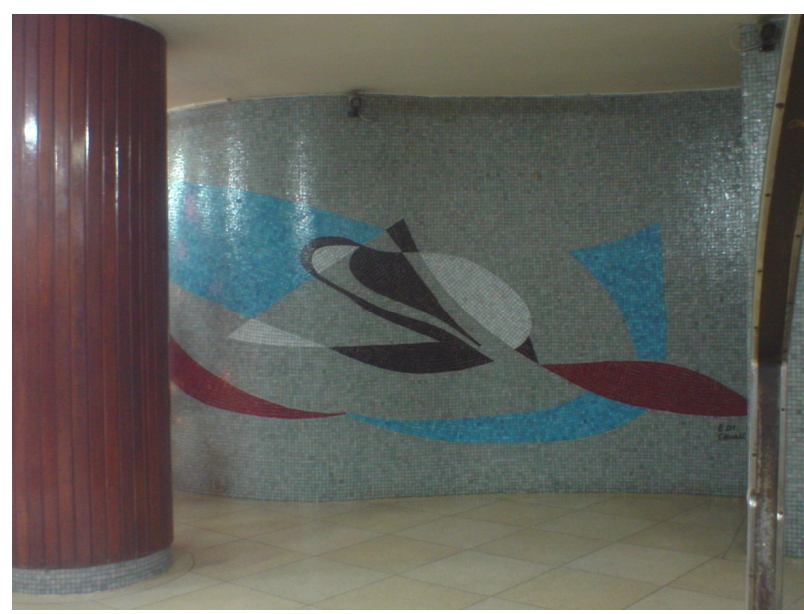

Figura 76 - Mosaico na parede interna do Edifício Montreal. (Foto da autora) 


\subsection{Edifício Califórnia}

Cândido Portinari

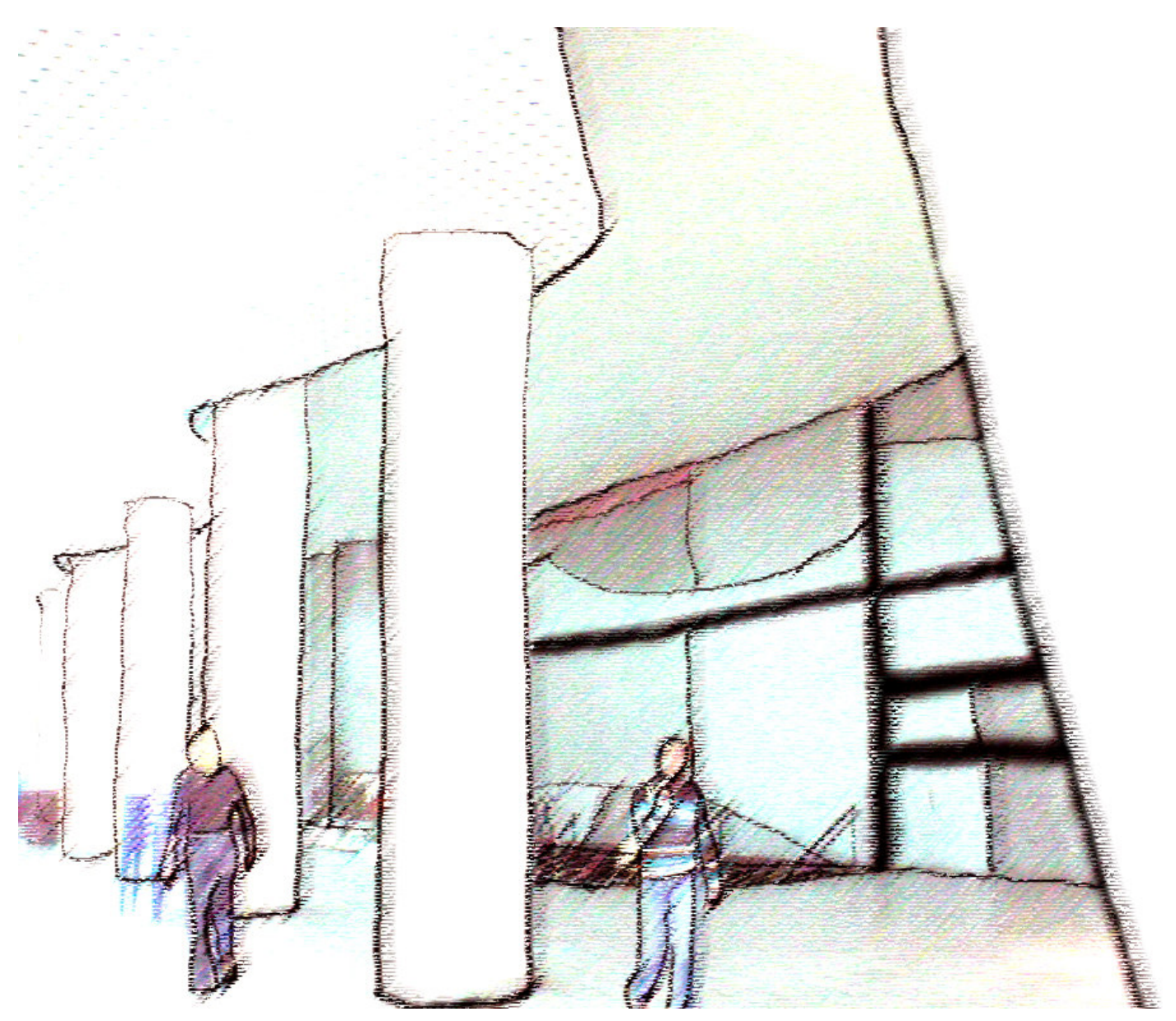

Figura 77 - Galeria do Edifício Califórnia. (llustração da autora) 


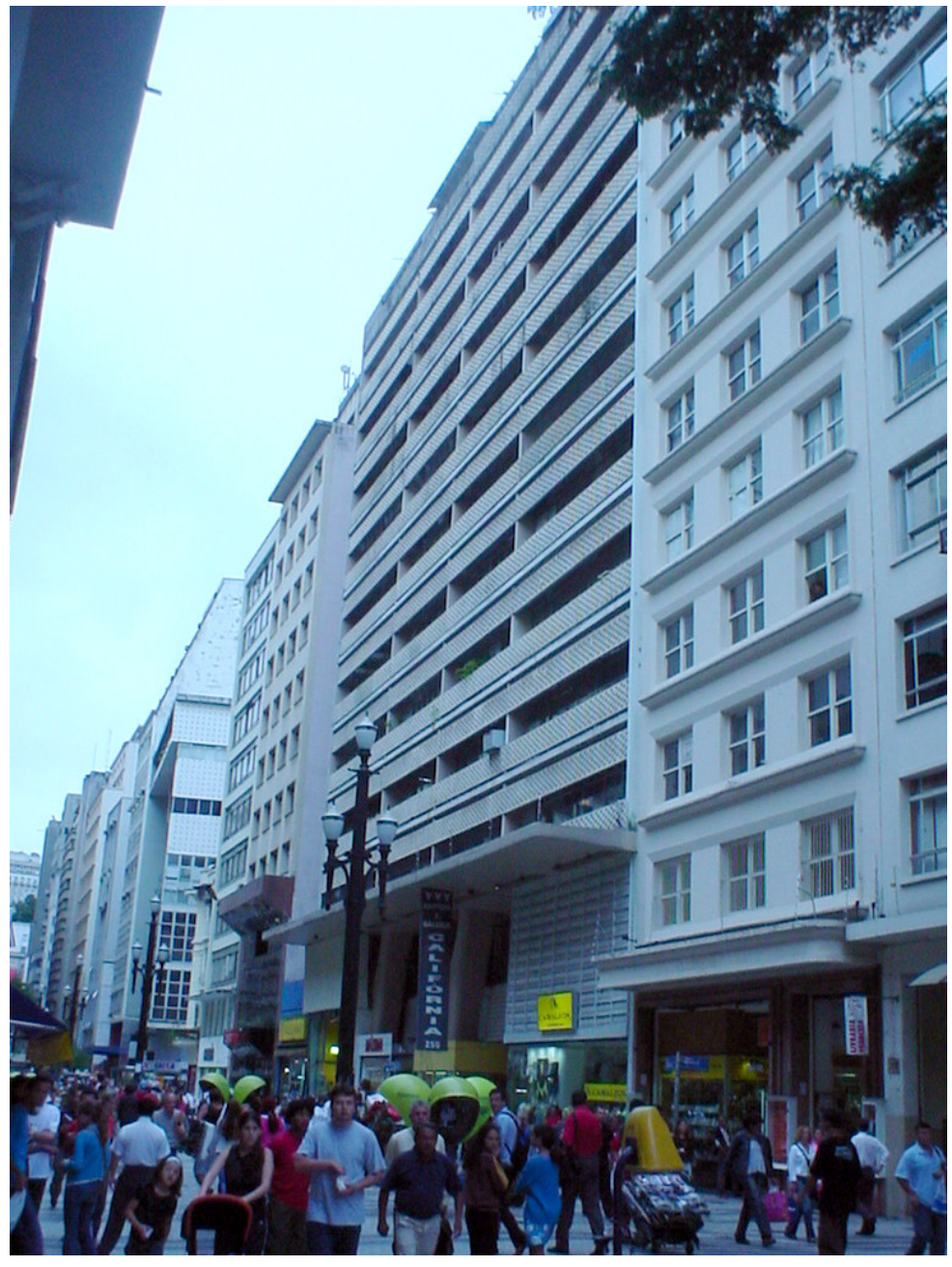

Figura 78 - Edifício Califórnia. (Foto da autora)
Esta obra é bastante polêmica, até o próprio Portinari não a considerava importante, como foi relatado por Isabel Ruas, que teve a oportunidade de entrevistar o arquiteto Carlos Lemos em maio de 2000: $:^{37}$

\section{Conta Lemos que Portinari tinha sido} encarregado de fazer o cartão de um painel em mosaico para o Califórnia, projeto de Oscar Niemeyer. Teria recebido $50 \%$ do pagamento e estava sem tempo para fazer o trabalho. O edifício já em fase de acabamento e o cartão para o painel não chegava. Carlos Lemos, arquiteto coordenador do escritório de Niemeyer em São Paulo, foi então ao Rio de Janeiro para solicitar de Portinari a realização do trabalho. $O$ artista não teve dúvida - fez naquele mesmo momento um desenho simplificado e esquemático para o painel, que entregou a Lemos, recusando o pagamento dos restantes $50 \%$.

${ }^{37}$ COELHO, Isabel Ruas Pereira. Painéis em mosaico na arquitetura moderna paulista. - 1945-1964 São Paulo: dissertação de mestrado. Faculdade de Arquitetura e Urbanismo da Universidade de São Paulo, 2000. p. 113. 


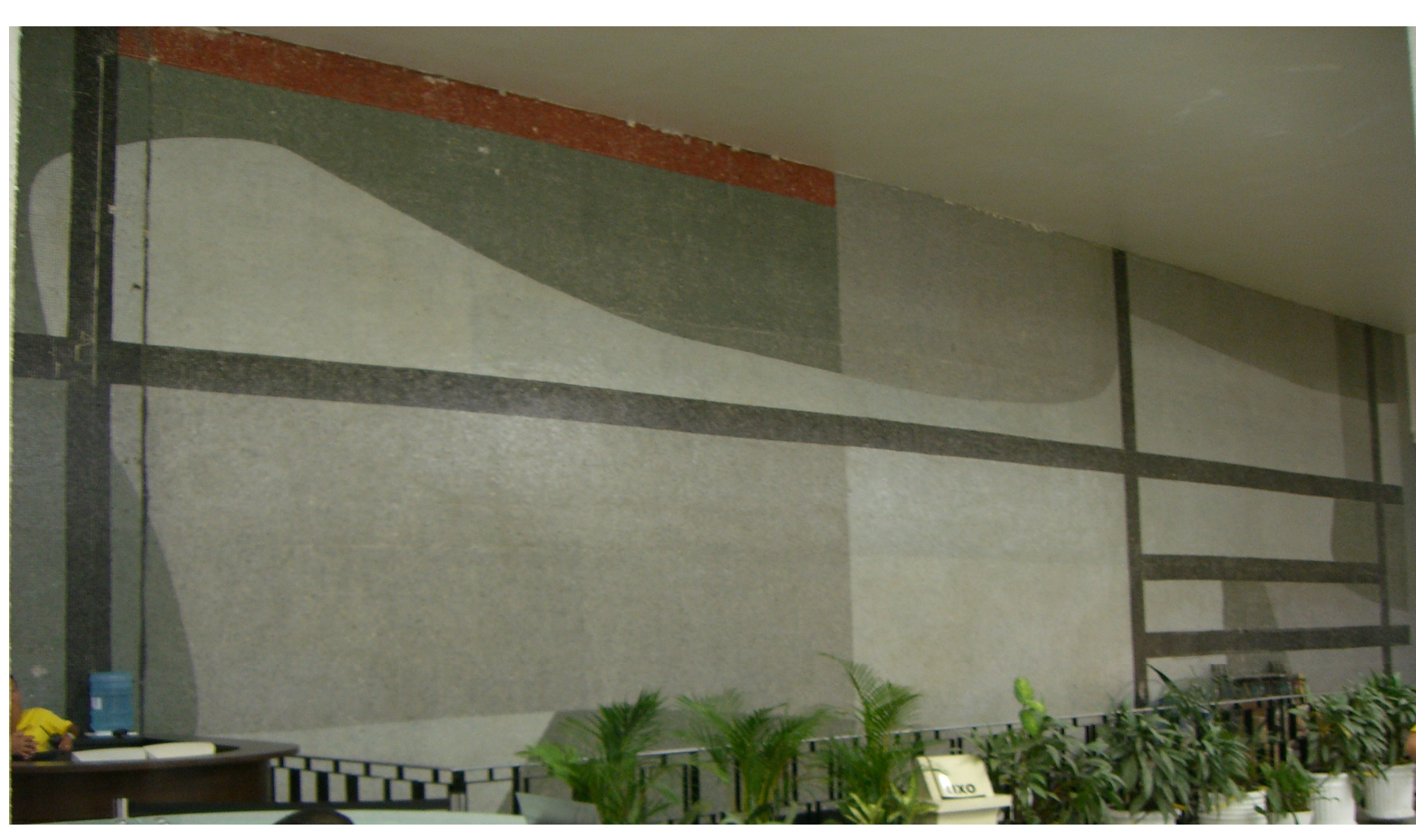

- Autor: Cândido Portinari (19031962).

- Arquiteto: Oscar Niemeyer.

- Endereço: Rua Barão de Itapetininga, 255, São Paulo, SP.

- Implantação: Parede interna, na galeria, no pavimento térreo.

- Uso do edifício: comercial com escritórios e lojas.

- Data: 1954.

- Tema: abstrato.

- Dimensões: $600 \times 3000 \mathrm{~cm}$

- Assinatura: canto inferior direito.

- Transcrição da assinatura: PORTINARI.

- Data da avaliação: jan/2005.

Figura 79 - Mosaico de Portinari no Edifício Califórnia. (Foto da autora) 


\subsection{Edifício Triângulo} Emiliano Di Cavalcanti

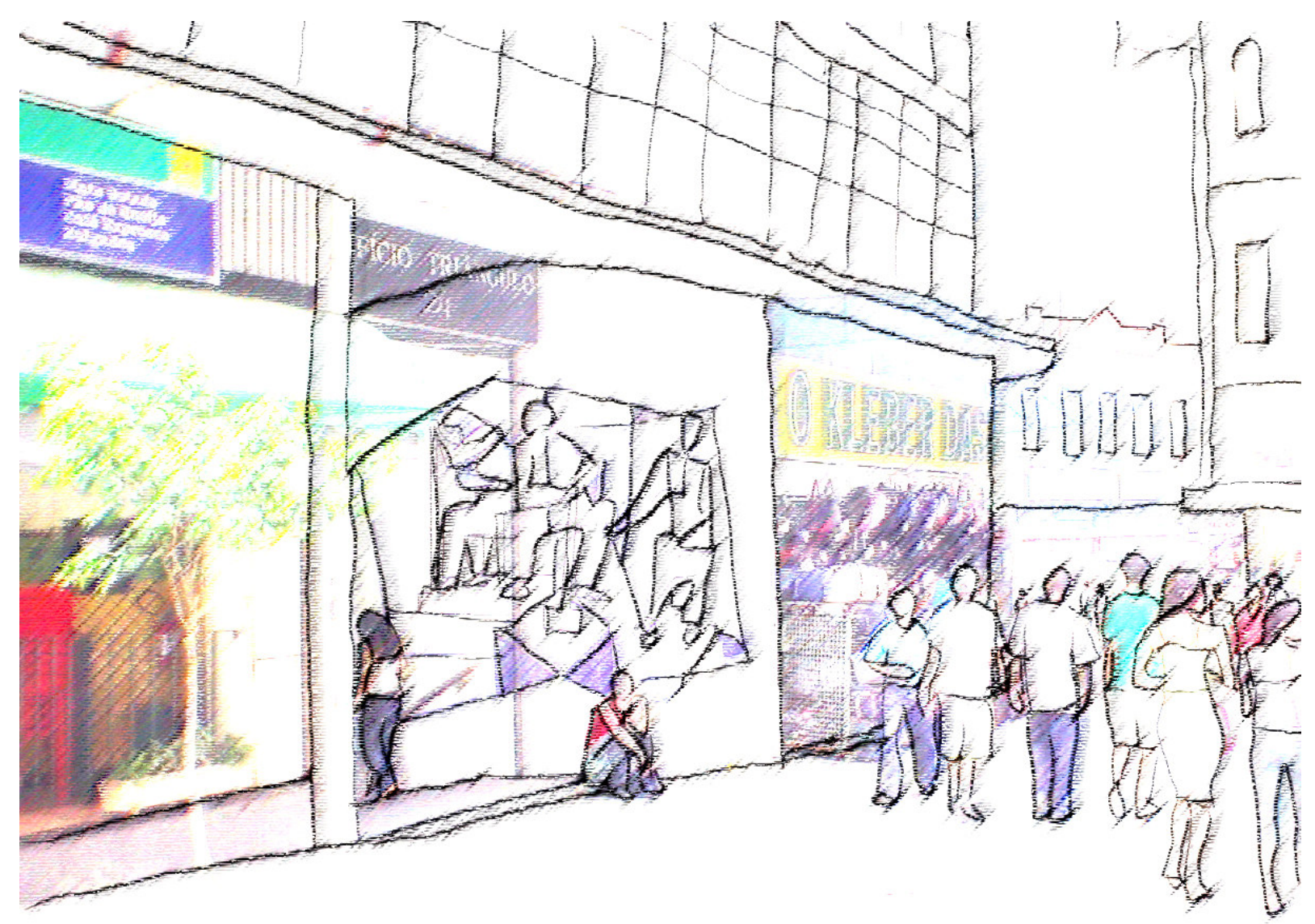

Figura 80 - Acesso do Edifício Triângulo. (llustração da autora) 


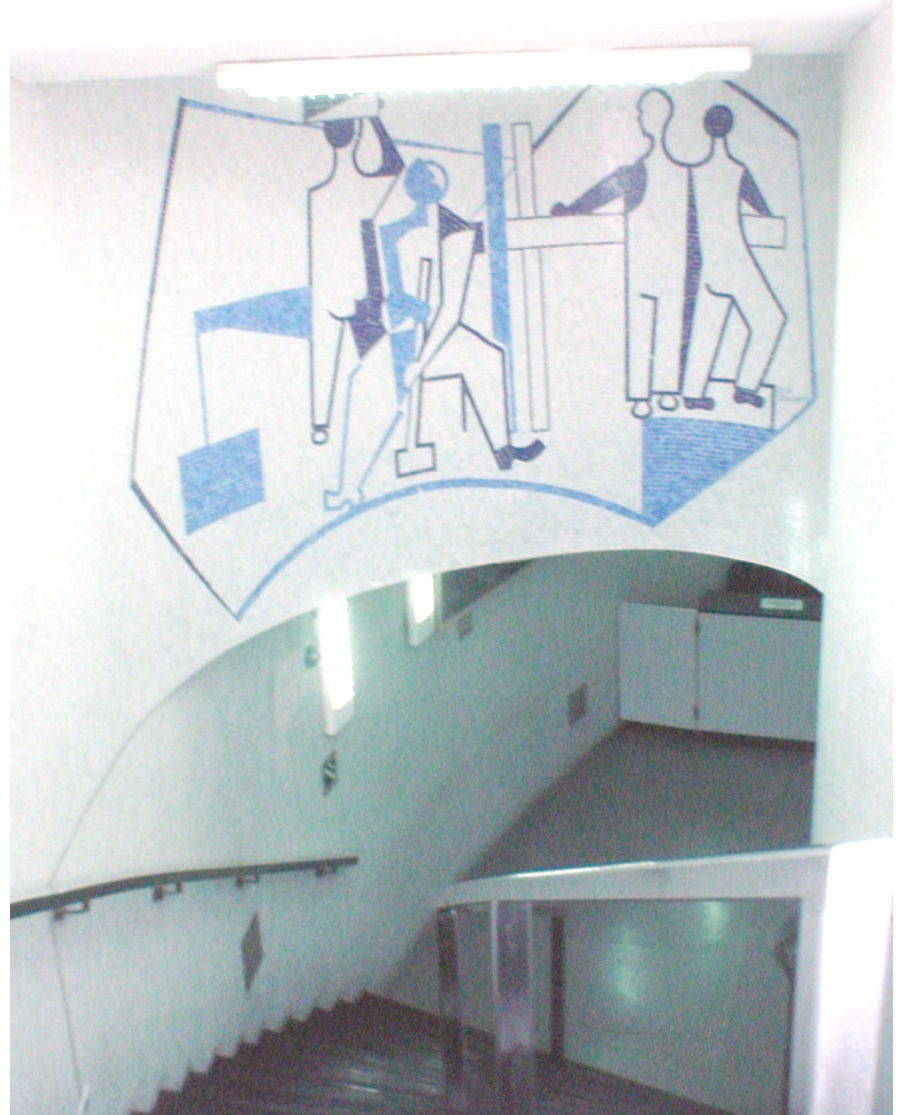

Figura 81 - Mosaico posicionado acima da escada. (Foto da autora)
No Edifício Triângulo, projetado por Oscar Niemeyer, estão dois mosaicos, um interno, acima da escada de acesso que desce e outro na face externa do edifício, parte junto à rua e parte junto à escada. Ambos estão em uma mesma parede curva.

Mais uma vez os trabalhadores estão retratados em mosaico por Di Cavalcanti. No interior do edifício eles aparecem trabalhando e os que estão junto à calçada são retratados descansando, como se tivessem mesmo se encostado na parede num momento de folga.

O mosaico de Di Cavalcanti deixa a obra de Niemeyer mais fluida. Maria Cecília França Lourenço descreve a visão desta obra pelo transeunte:

"Valorizando a obra arquitetônica, captando o andante, Di Cavalcanti faz um mosaico na parede externa e que se desenvolve em direção ao interior do edifício; da rua se vê a composição; ao se aproximar 


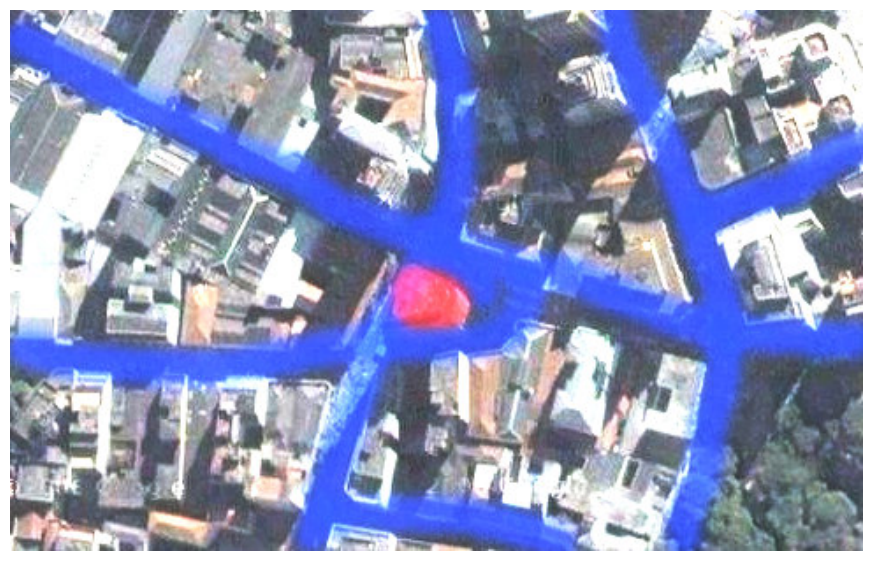

Figura 82 - Esquema com Edifício Triângulo em vermelho e as ruas que o cercam em azul. da porta, imediatamente outra, da parte interna, desponta, dando sensação seqüencial às duas. '38

O Edifício Triângulo tem a planta triangular, e está sozinho cercado pelas ruas Quintino Bocaiúva, José Bonifácio e Rua direita, no centro de São Paulo. Pela escala do edifício e seu entorno, não seria errado considerar que, na prática, o edifício está localizado no cruzamento das três ruas.

Segundo Kevin Lynch, o cruzamento é um elemento de grande importância na cidade porque é o lugar onde as pessoas decidem por qual via seguirão e por isso elas ficam mais atentas aos elementos do local. ${ }^{39}$ Isso significa que o Edifício Triângulo é um foco e, portanto, seria esperado que o mosaico de Di Cavalcanti estivesse em evidência. Porém, não é isso o que se verifica.

No mosaico, foram usadas poucas cores, dois tons de azul sobre fundo branco, o que dá uma leveza condizente

\footnotetext{
${ }^{38}$ LOURENÇO, Maria Cecília França. Operários da Modernidade. São Paulo: Hucitec/Edusp, 1995.

${ }^{39}$ LYNCH, Kevin. A imagem da cidade. Lisboa: Edições 70.
} 


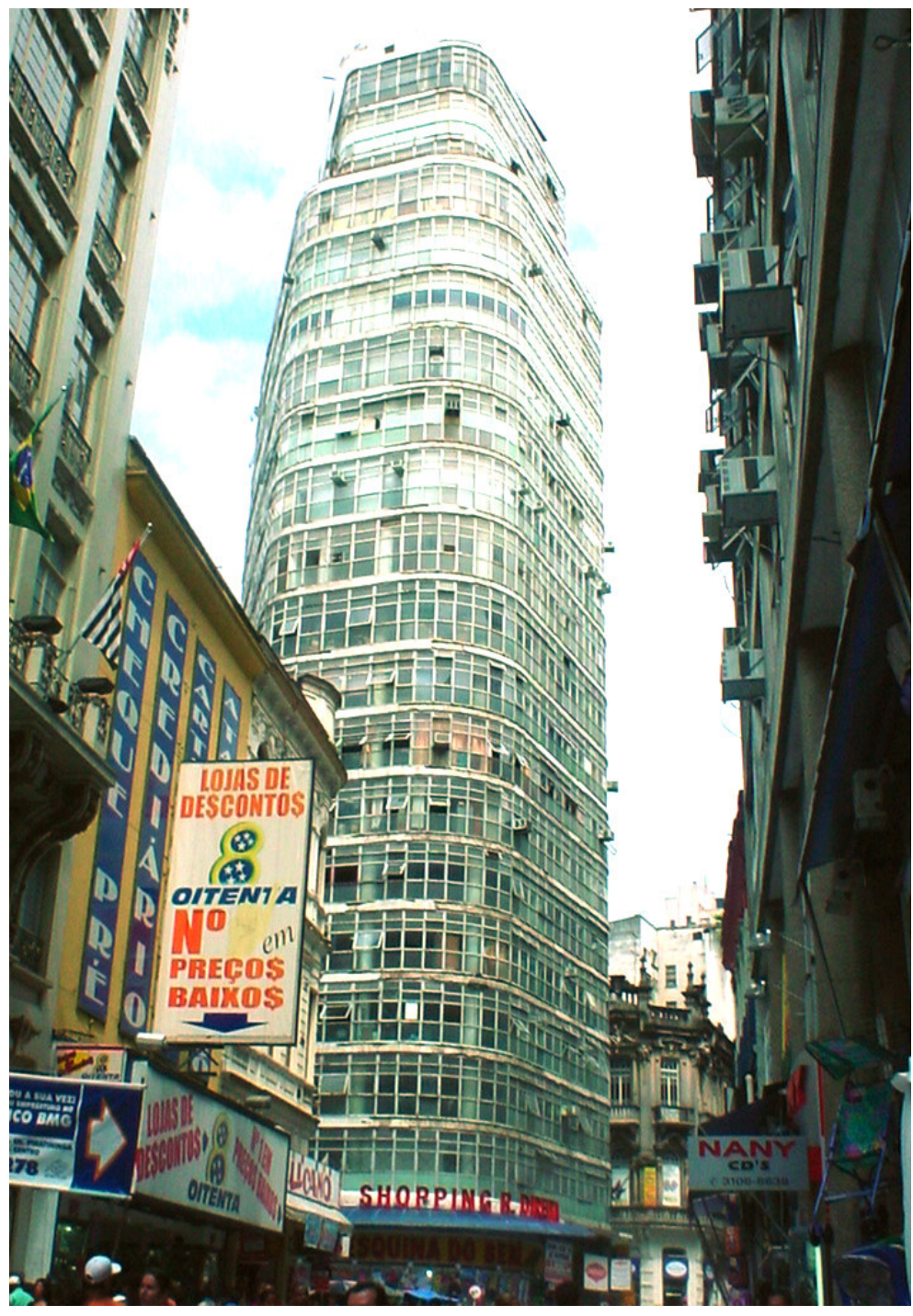

Figura 83 - Edifício Triângulo. (Foto da autora) com o vidro que reveste todo o Ed. Triângulo. Infelizmente, o mosaico não fica em evidência por causa do ruído visual do comércio no entorno que se impõe com cores chamativas.

Além disso, existe como agravante o fato de que o mosaico da parte externa do edifício está muito malconservado. Esse estado de abandono faz parecer que as mercadorias nas lojas são mais importantes do que a obra de arte no espaço da cidade.

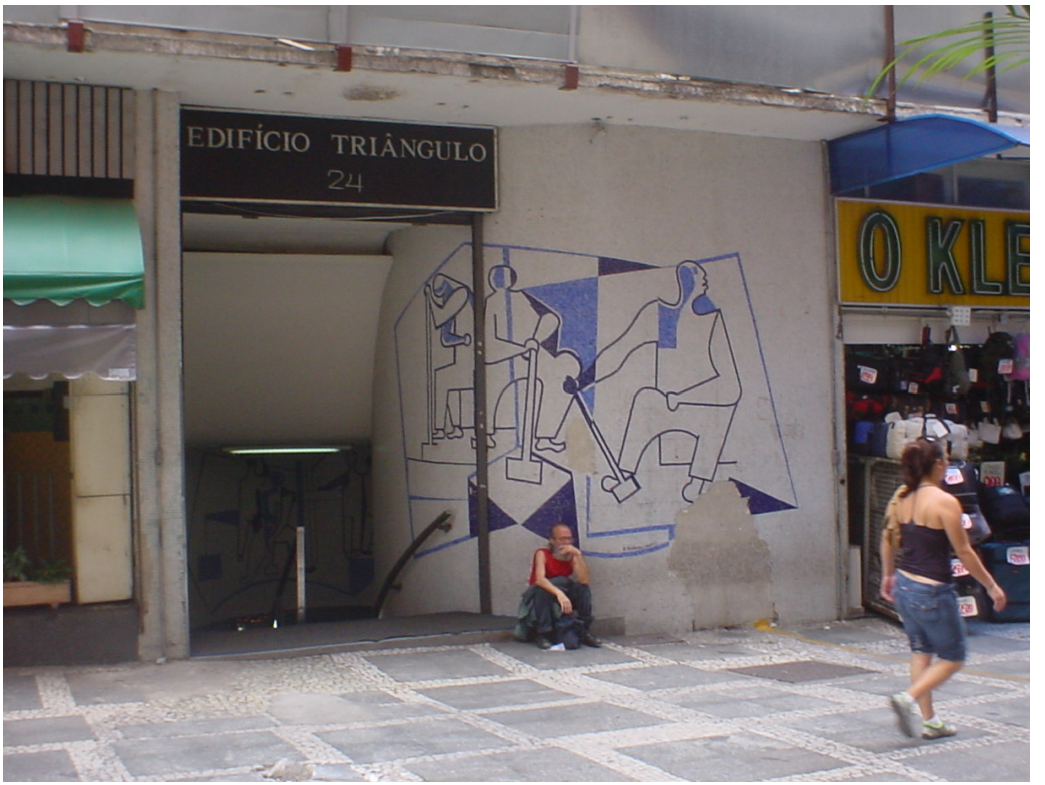

Figura 84 - Acesso do Edifício Triângulo. (Foto da autora) 


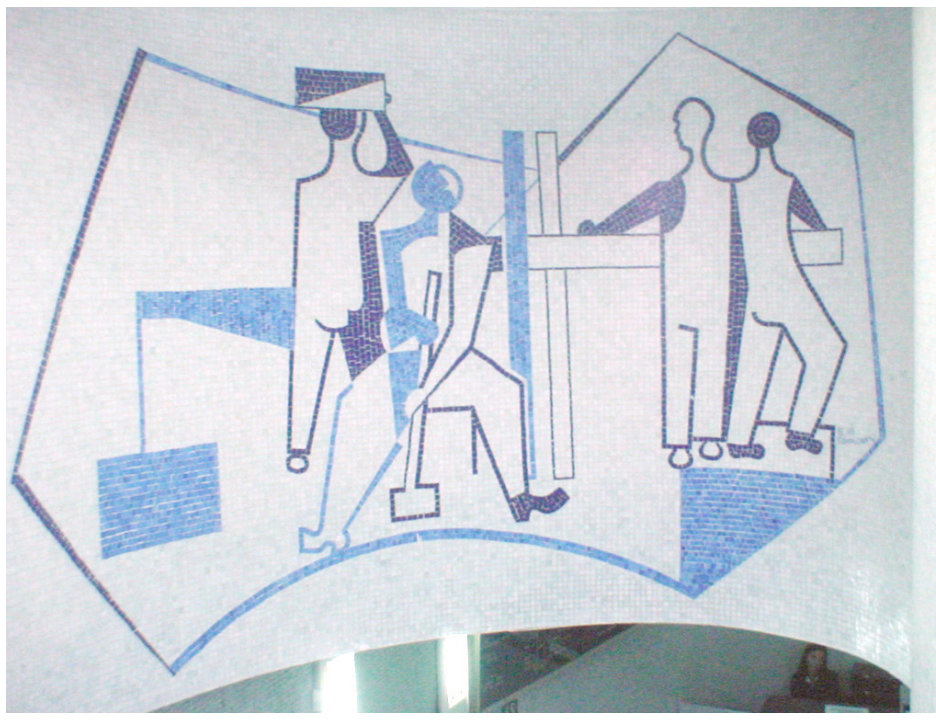

Figura 85 - Mosaico de Di Cavalcanti na parte interna do Edifício Triângulo. (Foto da autora)
- Autor: Emiliano Di Cavalcanti.

- Arquiteto: Oscar Niemeyer.

- Endereço: Rua José Bonifácio, 24, São Paulo, SP.

- Implantação: são dois murais, um está implantado ao lado direito da entrada do edifício e outro na parede acima da escada que desce já dentro do edifício.

- Uso do edifício: comercial com escritórios e lojas

- Data: 1955.

- Tema: figurativo - trabalhadores do café.

- Dimensões: 4,5x2,7m (aprox.).

- Assinatura: canto inferior direito.

- Transcrição da assinatura: E DI CAVALCANTI.

- Data da avaliação: jan/2005.

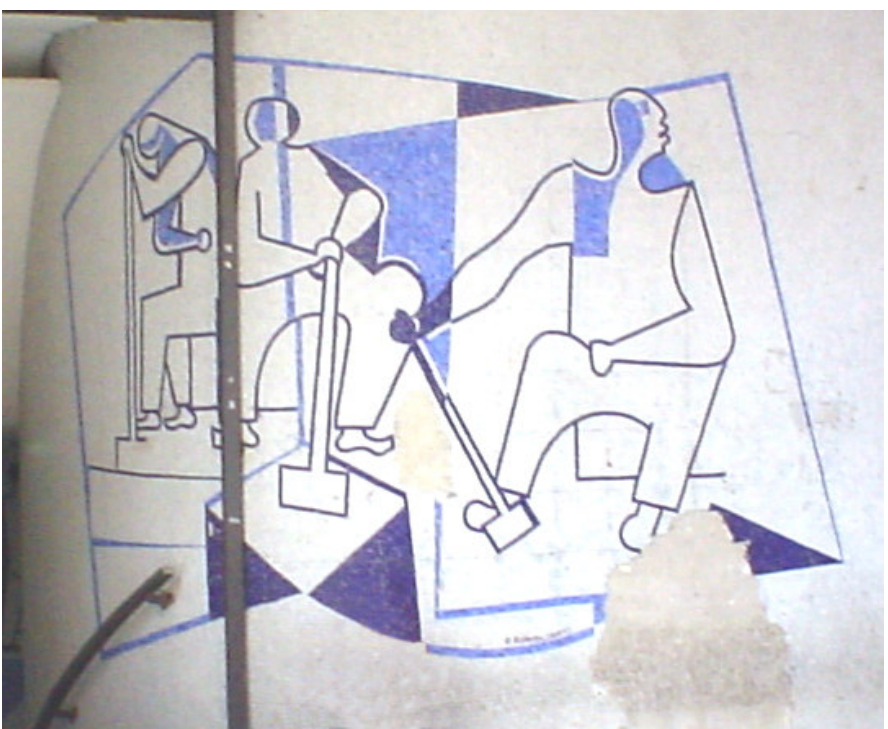

Figura 86 - Mosaico de Di Cavalcanti na parte externa do Edifício Triângulo. (Foto da autora) 


\subsection{Residência na Rua Filadelfo Azevedo}

Bramante Buffoni

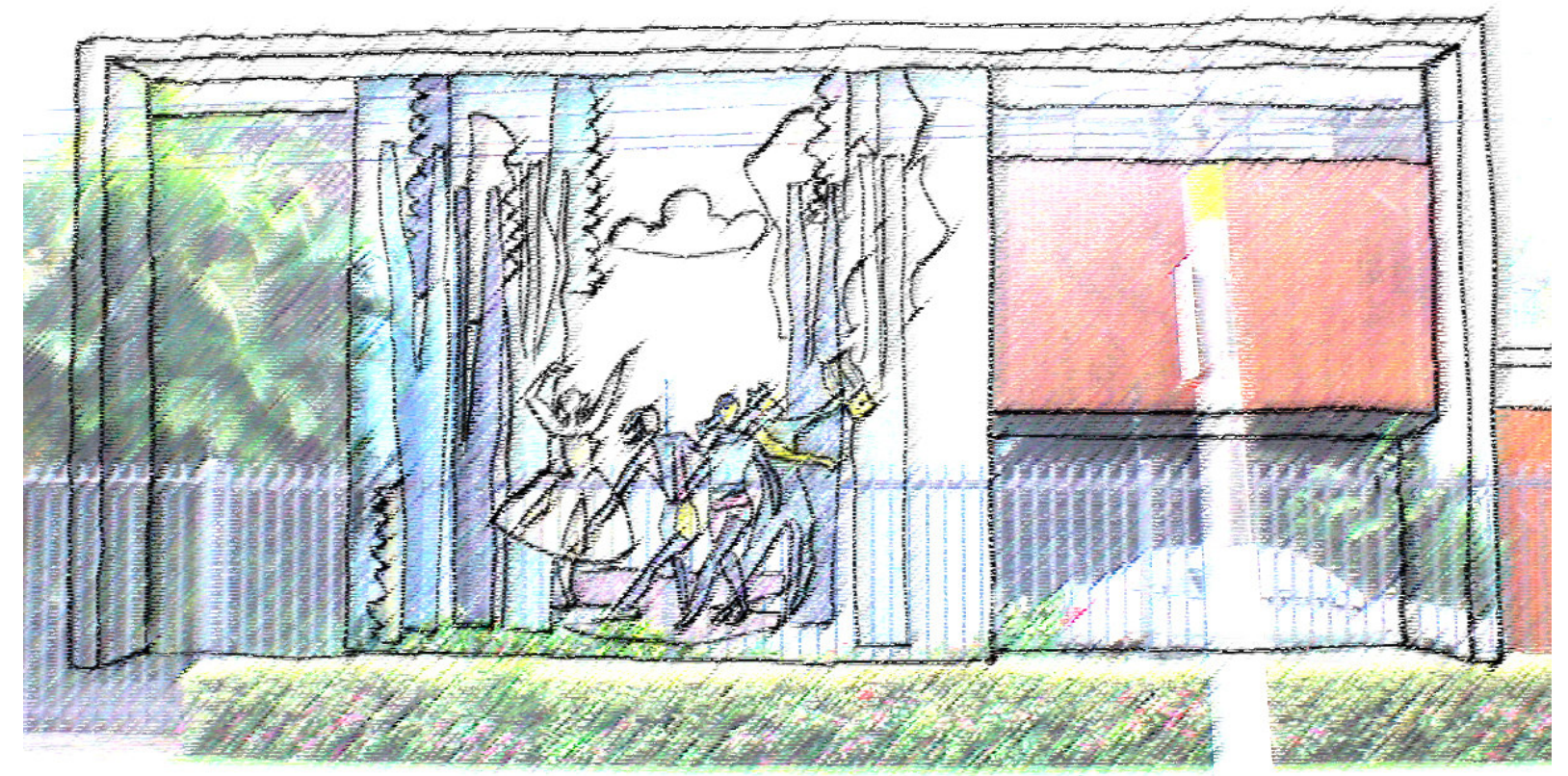

Figura 87 - Residência na Rua Filadelfo Azevedo. (Ilustração da autora) 


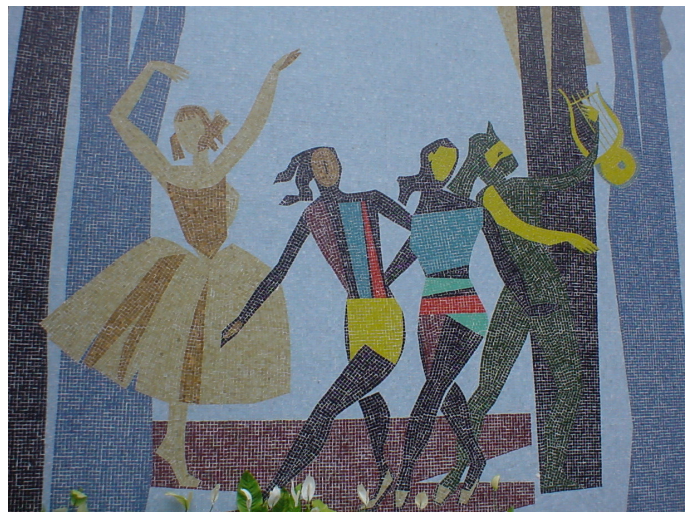

Figura 88 - Detalhe mostrando os bailarinos. (Foto da autora)

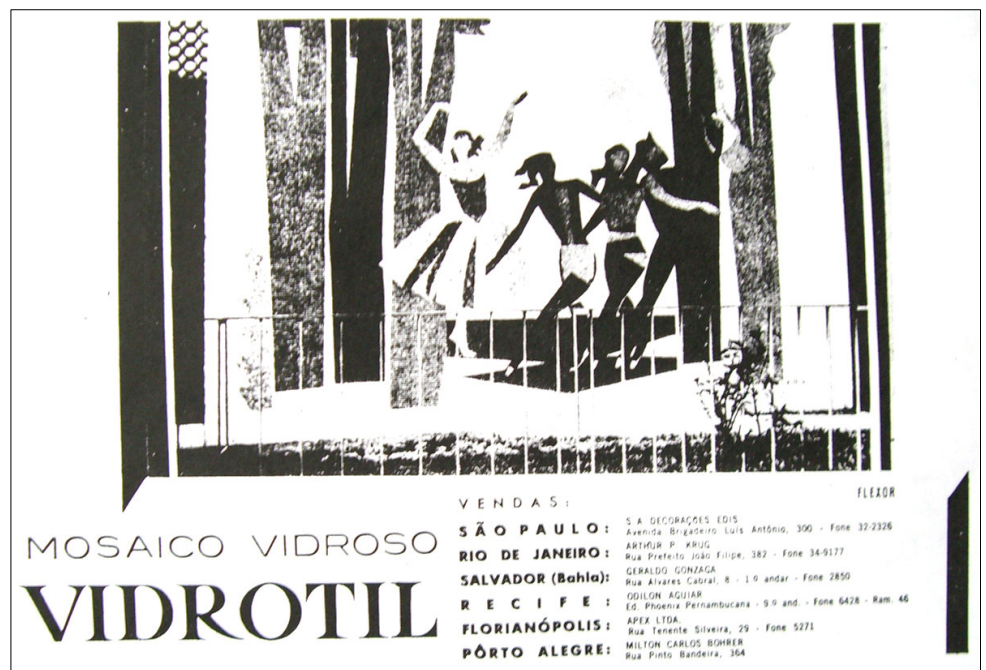

Figura 89 - Anúncio da fábrica de pastilhas de vidro Vidrotil mostrando mosaico de Buffoni. (Fonte: Revista Casa e Jardim no 46 , set./out. 1958)
Este mosaico tem um efeito monumental por sua escala, ocupando, aproximadamente, a metade da área da fachada da casa. A própria casa faz um papel de moldura para a obra de Buffoni, lembrando a moldura de cortinas definindo o espaço de uma encenação de teatro.

Sua forma quadrada está completamente de acordo com o contexto, mas, se observada isoladamente, a obra perde sua monumentalidade e sua harmonia.

Foram utilizadas poucas cores colocadas uniformemente sobre cada parte delimitada do desenho. A composição em mosaico aparenta uma enorme colagem devido à ausência de linhas e, também porque as formas são simples. 


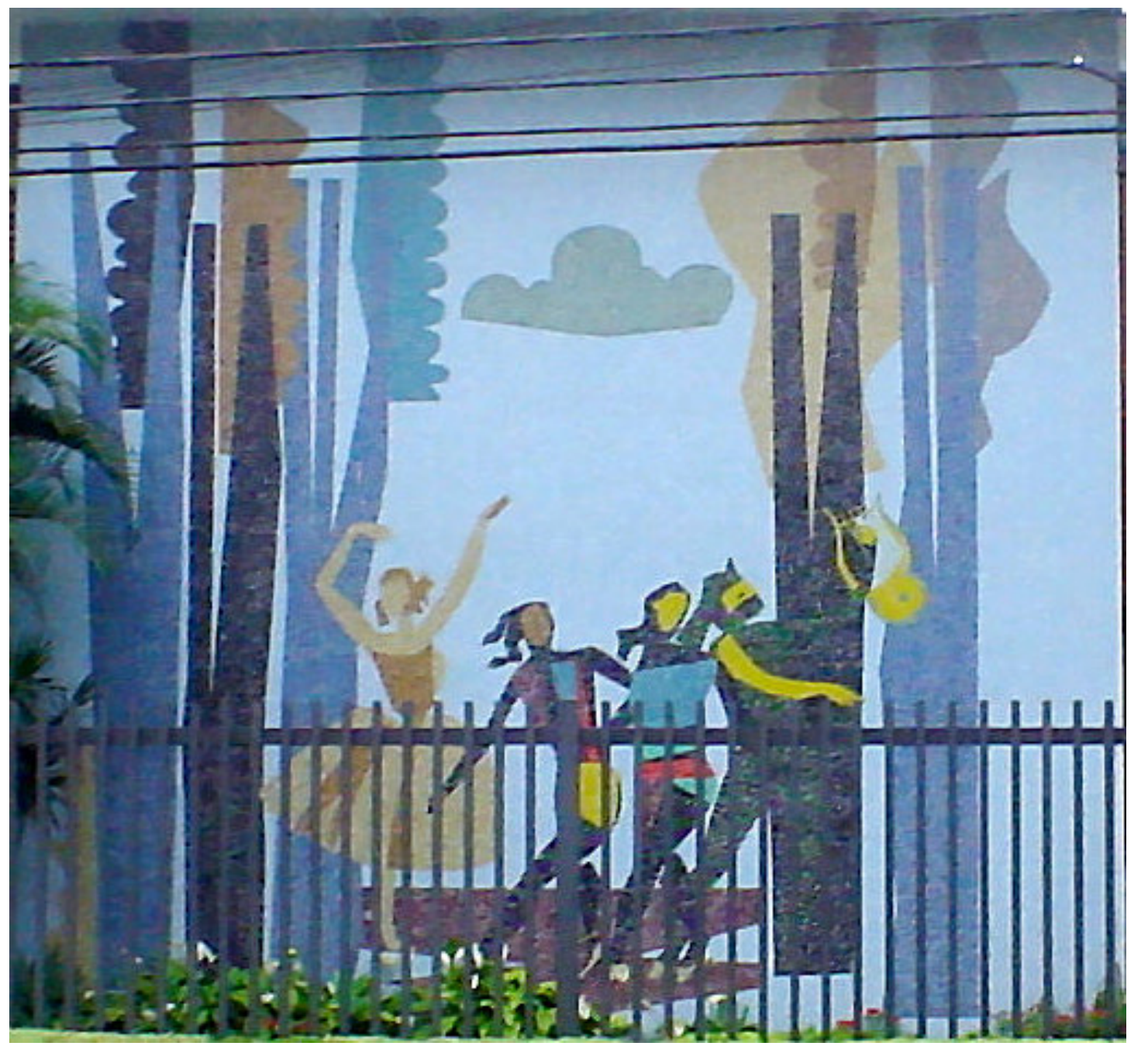

- Autor: Bramante Buffoni (18901965).

- Arquiteto: Eduardo Corona.

- Endereço: Rua Filadelfo Azevedo, 76, São Paulo, SP

- Implantação: parede externa.

- Uso do edifício: residência.

- Data: não encontrada, mas existe registro da existência do mosaico em 1958.

- Tema: bailarinos

- Assinatura: canto inferior direito.

- Transcrição da assinatura: Buffoni.

- Execução: Vidrotil.

- Data da avaliação: nov/2005.

Figura 90 - Mosaico de Bramante Buffoni na Rua Filadelfo Azevedo. (foto da autora) 


\subsection{Estação Sé Claudio Tozzi}

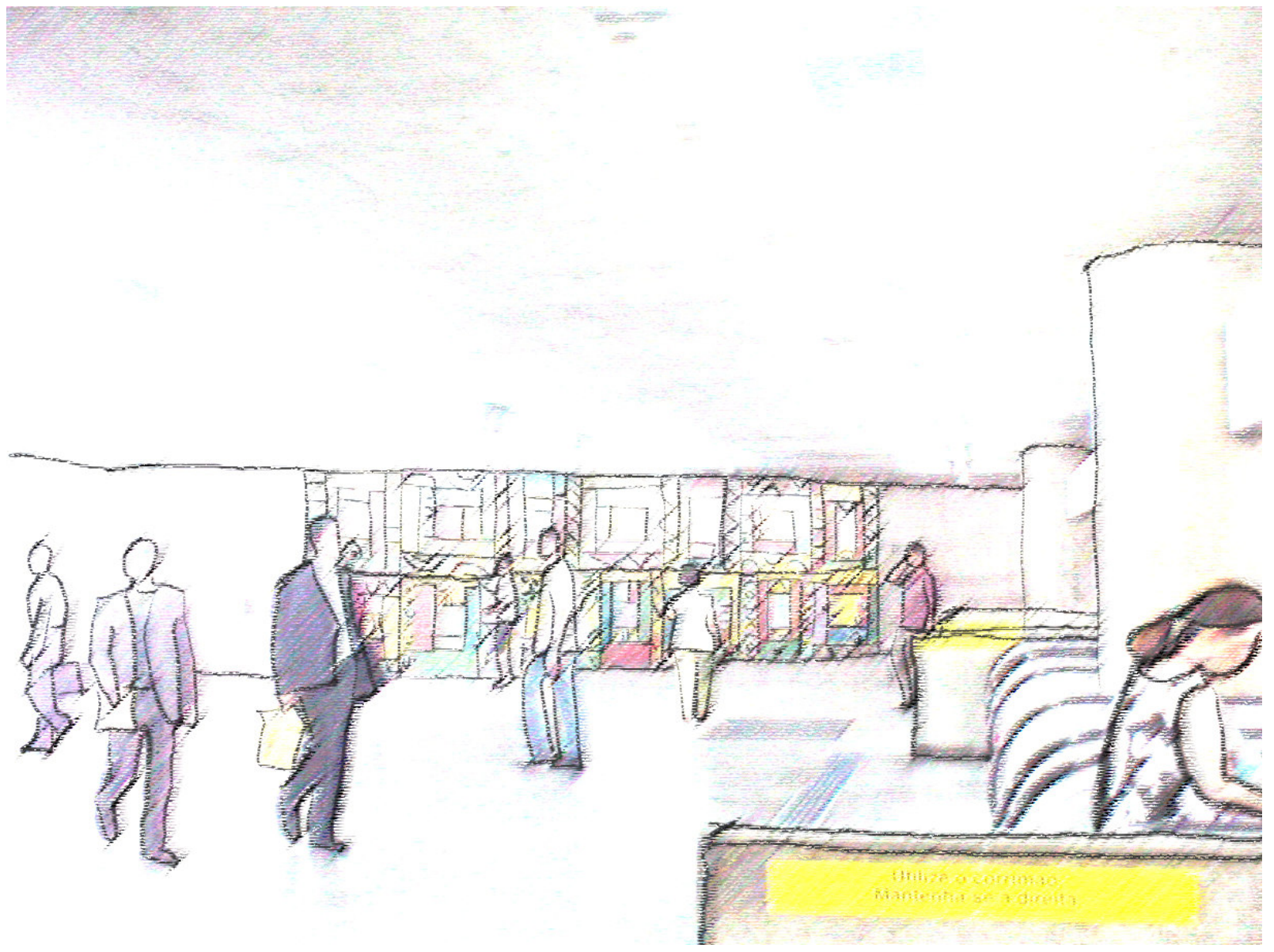

Figura 91 - Acesso norte da Estação Sé do metrô. (Ilustração da autora) 


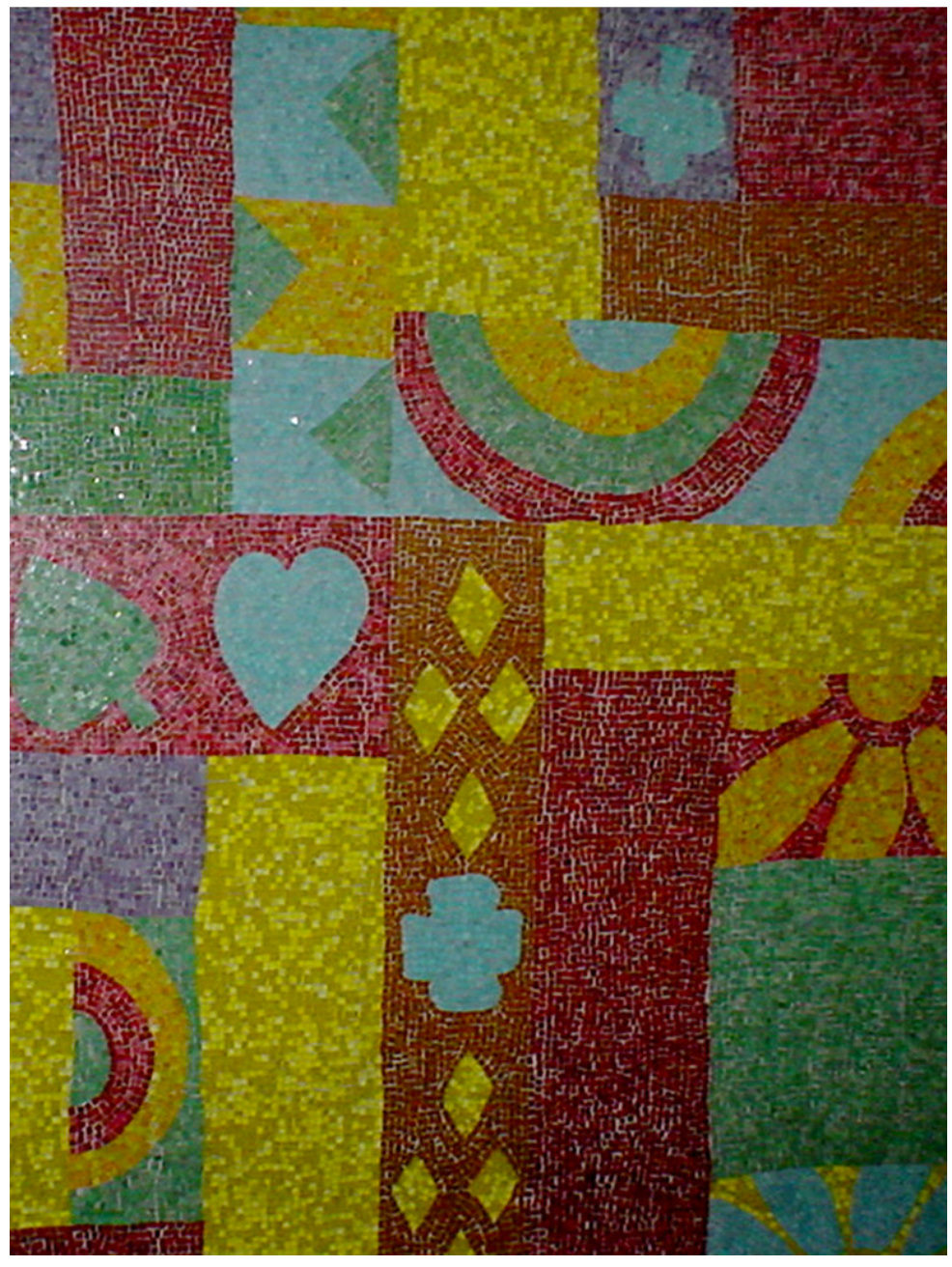

Figura 92 - Detalhe de Clocha de Retalhos. (Foto da autora)
Na Estação Sé do metrô, Colcha de Retalhos se destaca em um local predominantemente cinza pela sua vibração cromática. É um mosaico de um mosaico. Para quem passa apressado, a informação é a imagem do mosaico de retalhos, e, para quem pára à sua frente, além de ser um estímulo para a visão, é um estímulo para o tato, pois se encontra ao alcance das mãos.

O mosaico de pastilhas de $1 \times 1 \mathrm{~cm}$ foi executado pela equipe coordenada por Serafino Faro, no ateliê da Vidrotil.

Em entrevista a Fabio Magalhães ${ }^{40}$, no dia 8 de fevereiro de 2006, Claudio Tozzi falou como se deu a opção por executar Colcha de Retalhos no local:

Para o painel na estação Sé do metrô, preparei a partir da curadoria da Radha Abramo, três projetos: um astronauta, um trabalho com estrutura semelhante a uma colcha de retalhos e um desenho com a silhueta dos transeuntes, fundindo as imagens de quem passa,

\footnotetext{
${ }^{40}$ MAGALHÃES, Fabio, Claudio Tozzi. São Paulo: Ed. Lazuli e Companhia Editora Nacional, 2007. (no prelo).
} 


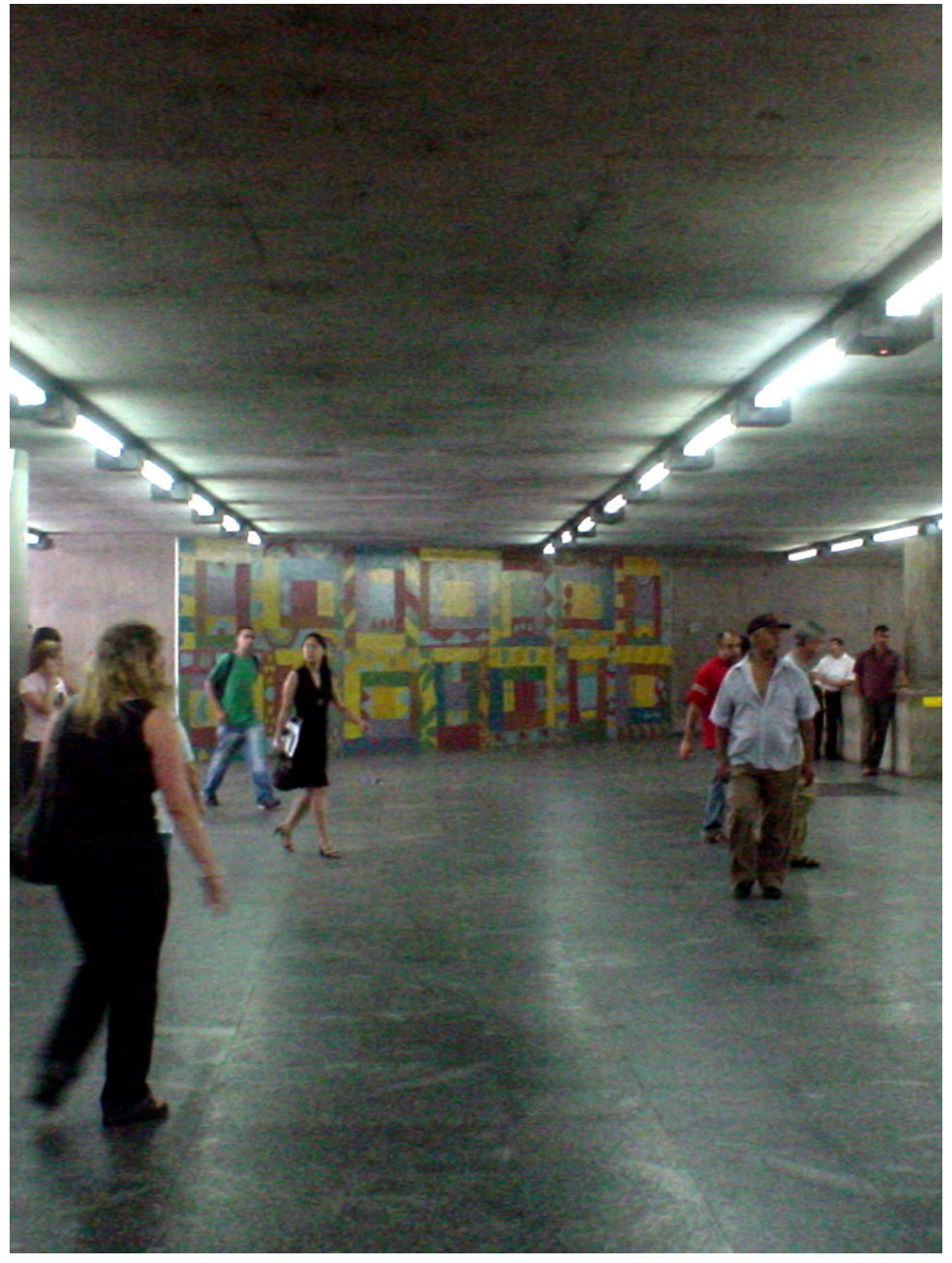

Figura 93 - Estação Sé. (Foto da autora) com o painel. Fizemos uma pesquisa, mostrando três maquetes, e achei que o público iria gostar mais do painel das silhuetas. No entanto o público escolheu o painel que está lá que é baseado na colcha de retalhos. Uma identificação do público com uma peça que ele mesmo produz: as colchas de retalhos feitas com restos de tecidos, nas periferias da cidade.

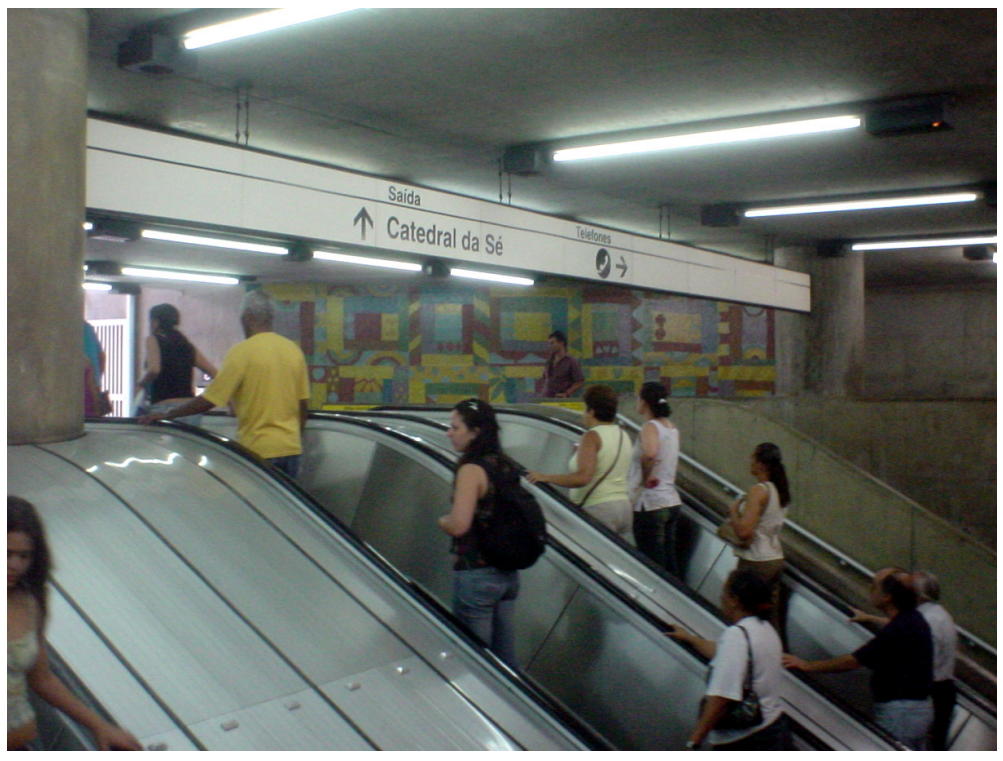

Figura 94 - Estação Sé. (Foto da autora) 
- Autor: Claudio Tozzi (1944-).

- Título: Colcha de Retalhos.

- Endereço: Estação Sé do metrô, São Paulo, SP.

- Implantação: Parede interna do acesso norte.

- Uso do edifício: estação de metrô.

- Data: 1979

- Dimensões: 3x10,5m

- Assinatura: canto inferior direito.

- Transcrição da assinatura: Clau Tozzi.

- Execução: Vidrotil.

- Data da avaliação: jan/2005.

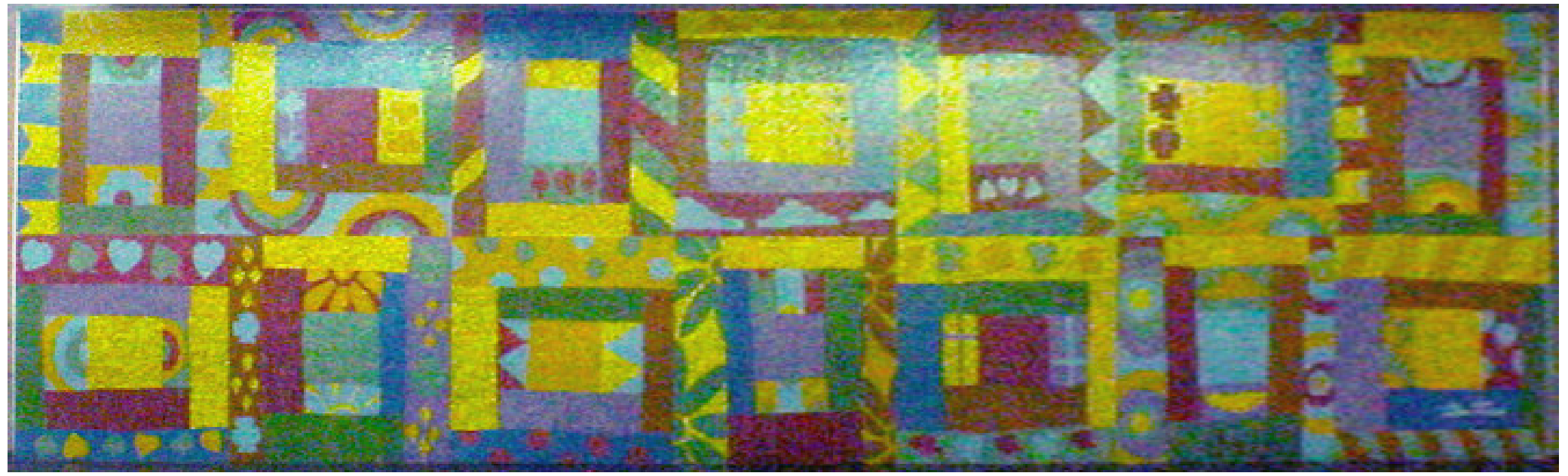

Figura 95 - Colcha de Retalhos. (Foto da autora) 


\subsection{SESC Consolação}

Claudio Tozzi

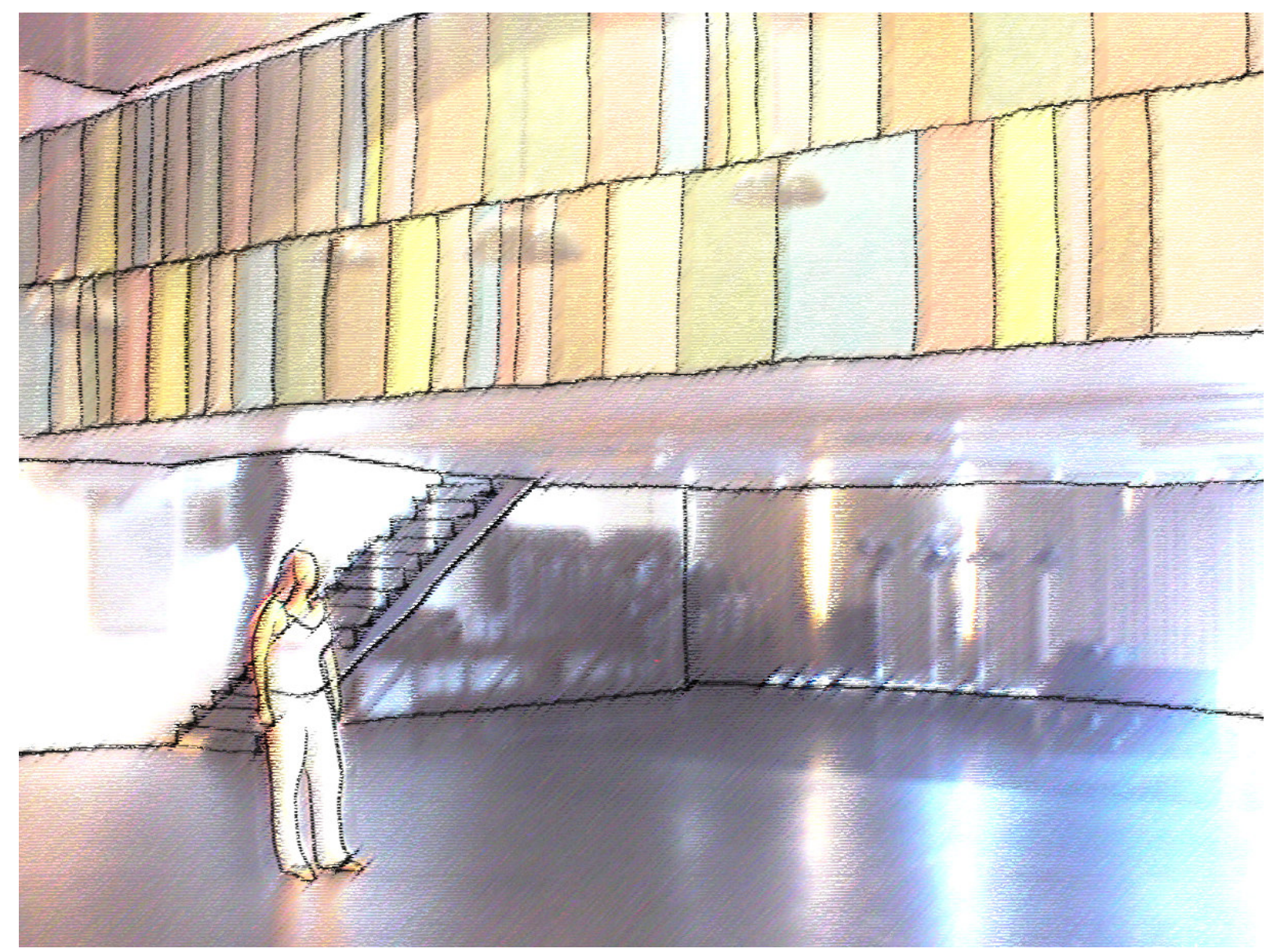

Figura 96 - Mosaico de Claudio Tozzi no SESC Consolação. (Ilustração da autora) 


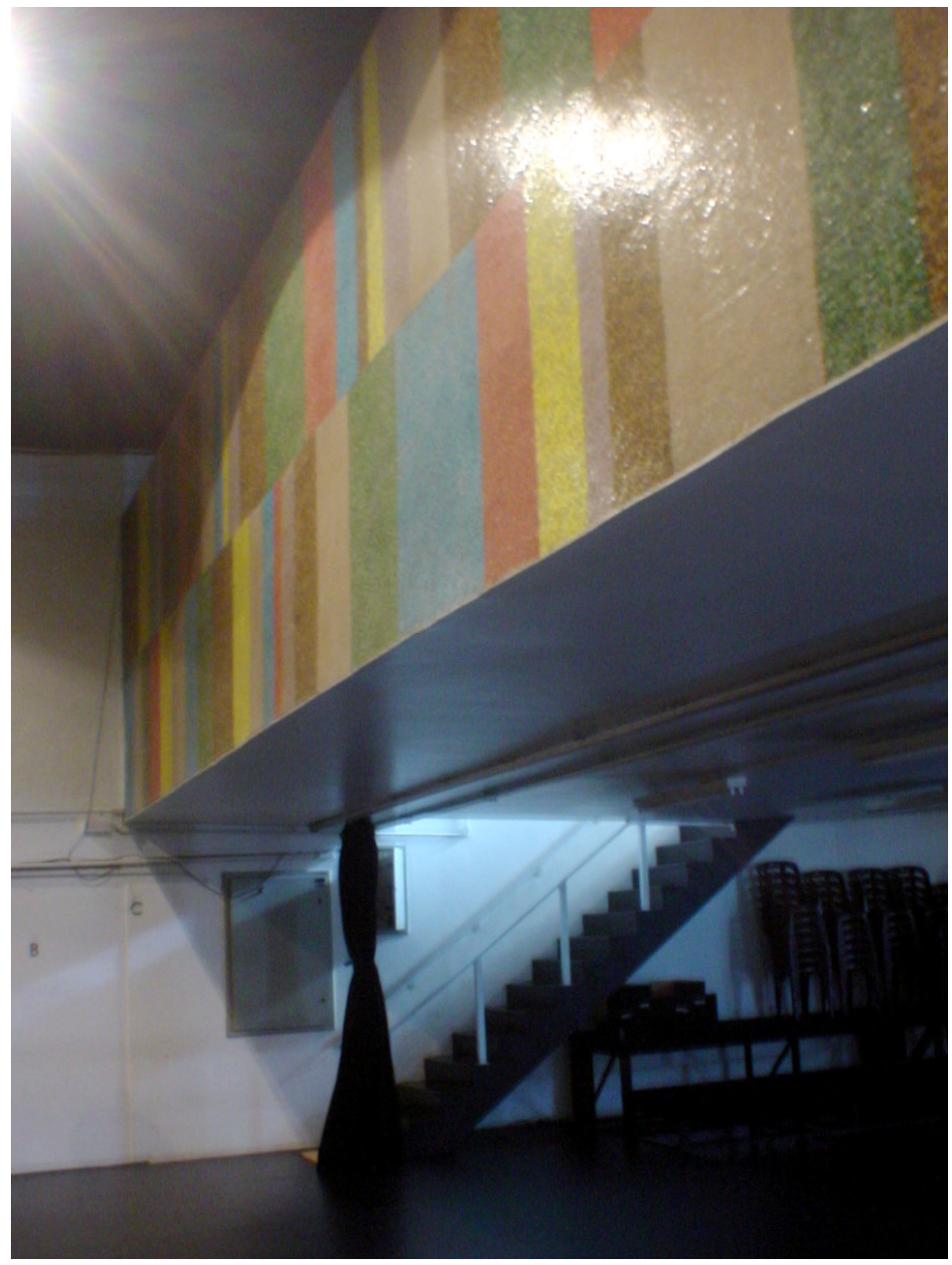

O mosaico de Claudio Tozzi na unidade do SESC está escondido em uma sala no $6^{\circ}$ andar, onde ocorrem os ensaios de teatro do Grupo Macunaíma de Antunes Filho.

A composição horizontal com faixas verticais encontrase compreendida entre o teto e o piso do mezanino. A parte superior do painel não chega a tocar o teto. Ele enfatiza não só o seu próprio plano, mas, também os dois planos horizontais.

Figura 97 - Mosaico de Claudio Tozzi no SESC Consolação. (Foto da autora) 
- Autor: Claudio Tozzi.

- Endereço: Rua Dr. Vila Nova, 245, São Paulo, SP.

- Implantação: parede de mezanino em uma sala fechada.

- Uso do edifício: espaço cultural e recreativo.

- Data: 1980.

- Tema: abstrato.

- Assinatura: canto inferior direito.

- Transcrição da assinatura: Clau Tozzi.

- Data da avaliação: dez/2006.

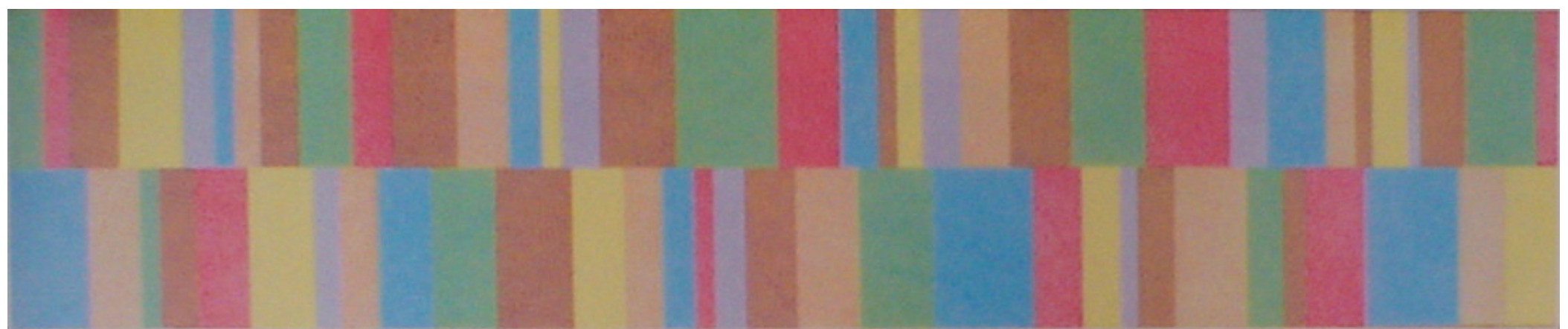

Figura 98 - Projeto cromático do painel do SESC Consolação. (Fonte: TOZZI, Cláudio José. O processo de construção da imagem e sua aplicação, relação com o espaço urbano: arte no lugar da arquitetura no fazer de um artista plástico/arquiteto. São Paulo: tese de doutoramento. Faculdade de Arquitetura e Urbanismo da Universidade de São Paulo, 2001.) 


\subsection{Estação Consolação}

Tomie Ohtake

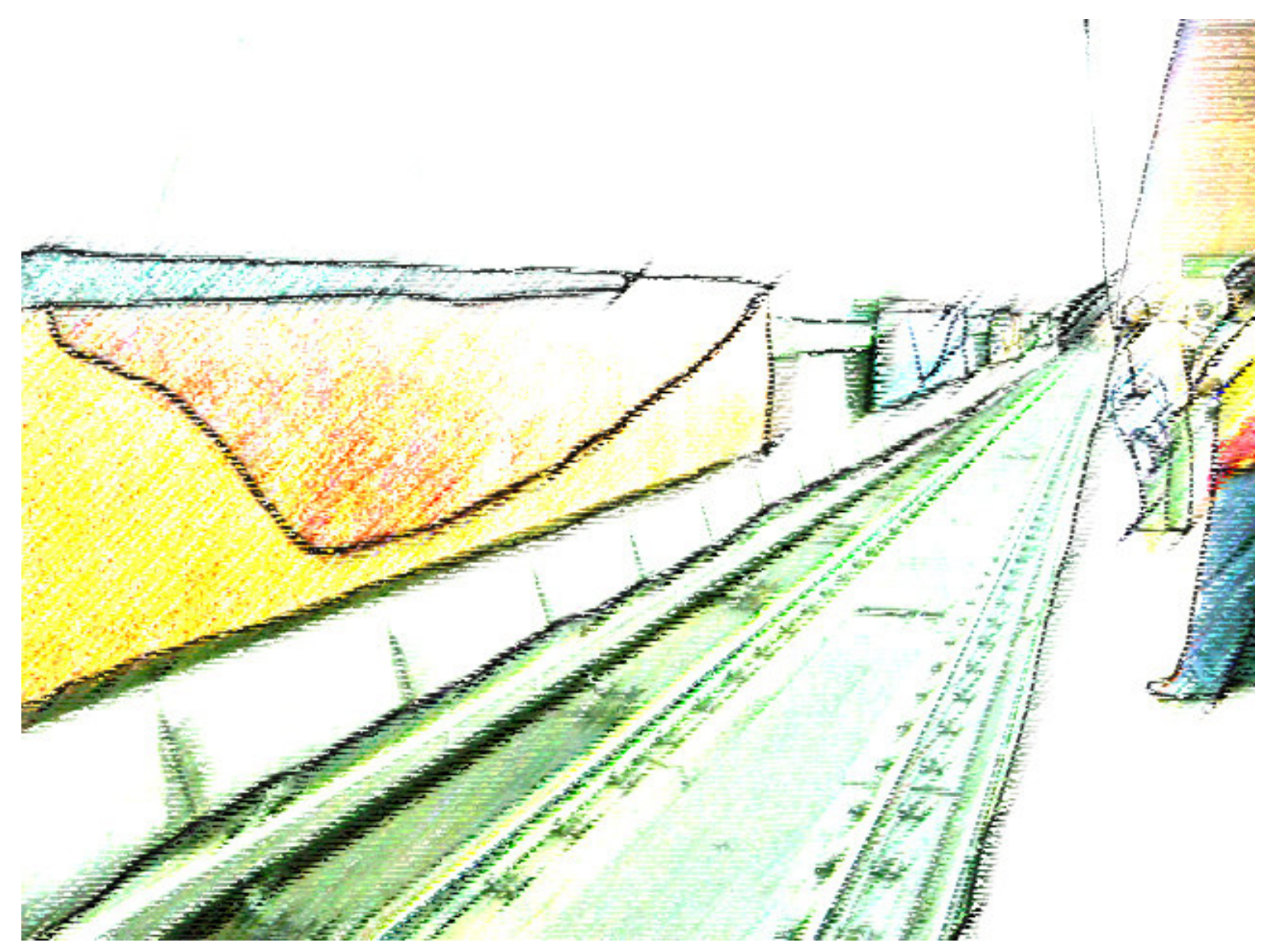

Figura 99 - Plataforma de embarque da Estação Consolação do metrô. (Ilustração da autora) 

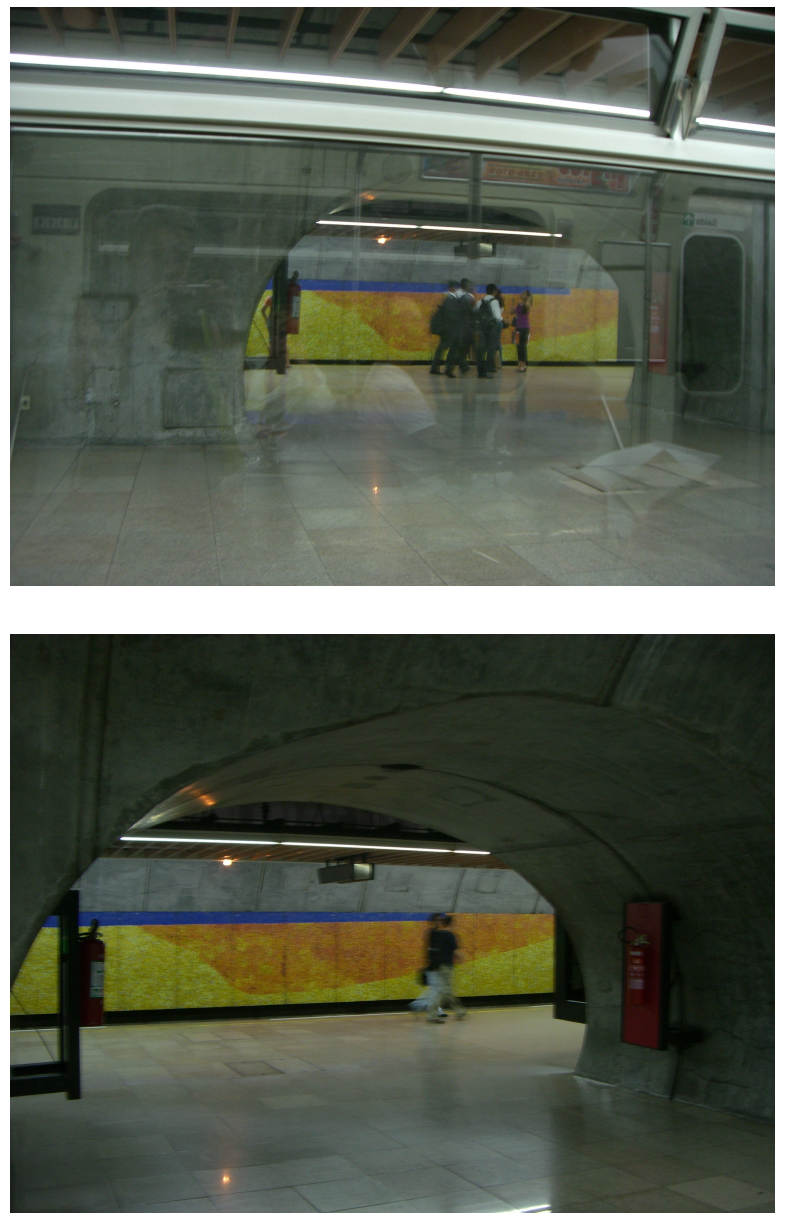

Figura 100 - Seqüência mostrando painel de Tomie Ohtake visto de dentro do trem e logo após desembarcar. (Fotos da autora)
Quatro Estações é uma série de quatro painéis dispostos ao longo da parede oposta à plataforma de embarque da Estação Consolação do metrô. O cinza do concreto aparente predomina no local e as curvas parecem acentuar a sensação de que é um subterrâneo.

O mesmo desenho é repetido em quatro painéis com quatro cores diferentes. Eles estão fixados em placas planas, predominantemente horizontais, sobre uma parede curva e não estão encostados na parede. A seqüência sugere ora o movimento do trem, ora o movimento das pessoas que caminham ao longo da plataforma. O movimento só existe com o tempo, e parece que neste local o tempo flui rapidamente.

Enquanto isso, para aqueles que estão parados, aguardando o trem, os detalhes das misturas de cores das pastilhas podem ser percebidos e, de tão vibrantes, também afetam a dimensão do tempo, "diminuindo" o tempo de espera. 

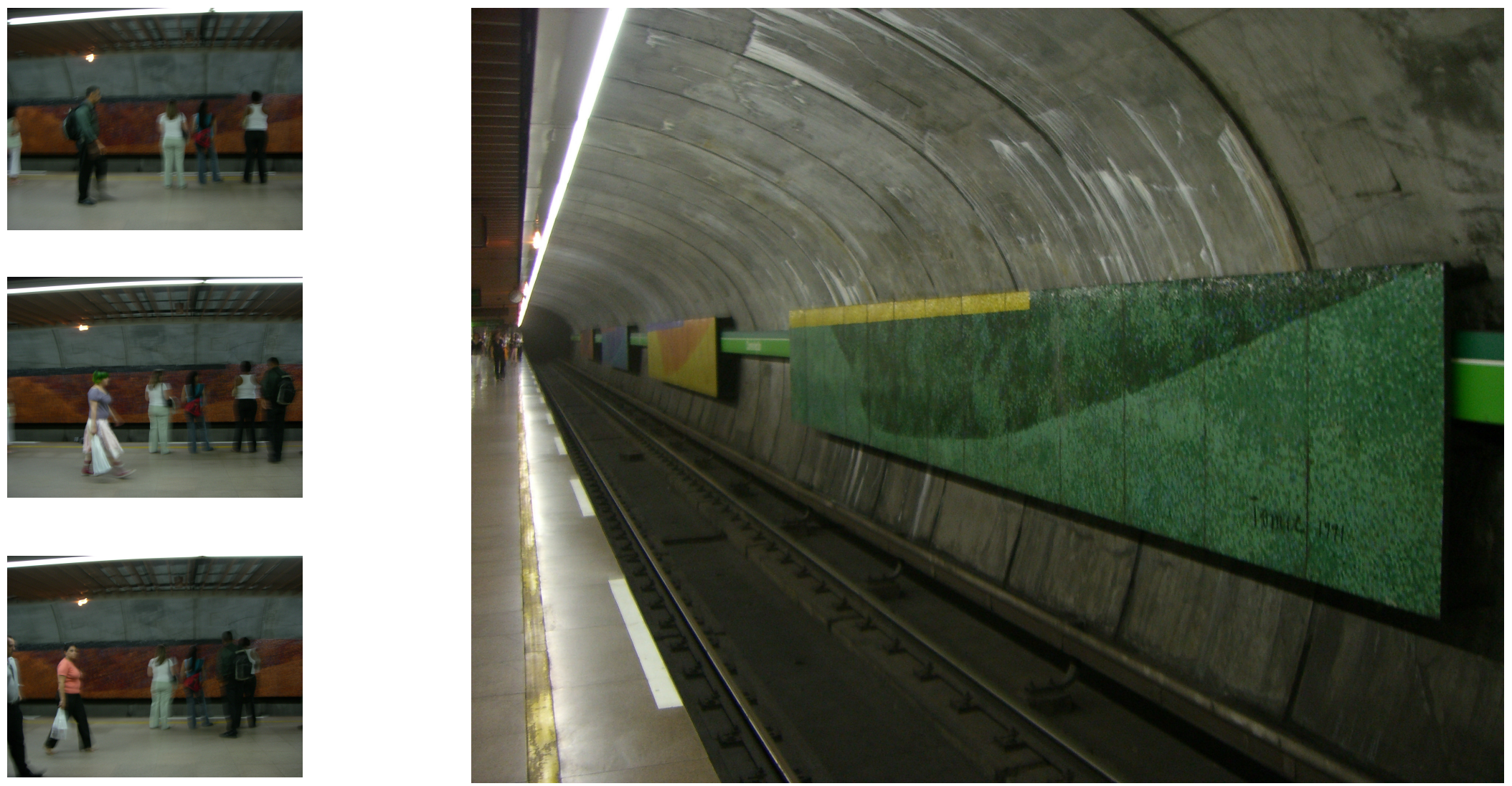

Figura 101 - Plataforma de embarque. (Fotos da autora)

Figura 102 - Vista dos quatro painéis acompanhando toda a extensão da plataforma de embarque. (Foto da autora) 

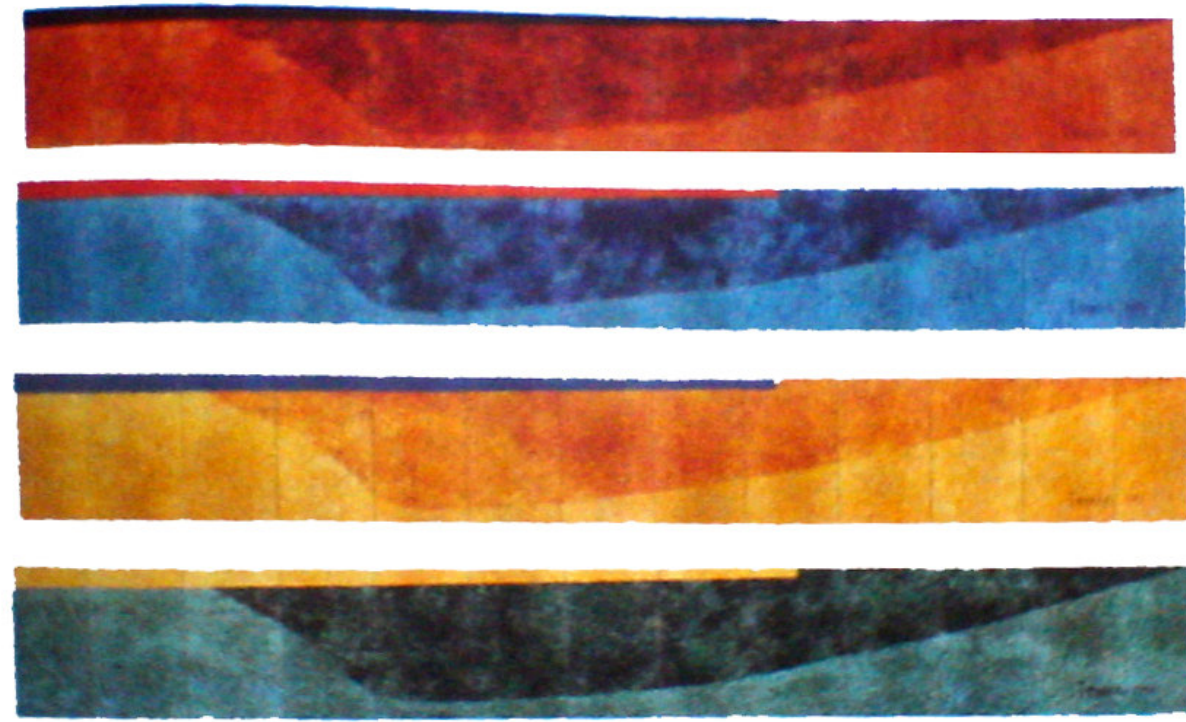

Figura 103 - Projeto dos quatro painéis de Quatro Estacões. (Fonte: ARTE NO METRÔ. São Paulo: Companhia do Metropolitano de São Paulo, 1994.)
- $\quad$ Autora: Tomie Ohtake.

- Título: Quatro estações.

- $\quad$ Endereço: Estação Consolação do metrô, São Paulo, SP.

- Implantação: Parede interna em frente à plataforma de embarque.

- Uso do edifício: estação de metrô.

- Data: 1991.

- Tema: abstrato.

- Dimensões: Quatro painéis de 200x1540cm.

- Assinatura: canto inferior direito, em todos.

- Transcrição da assinatura: Tomie 91.

- Execução: Vidrotil.

- Data da avaliação: jun/2006. 
3.14.

Estação Santo André Alex Flemming

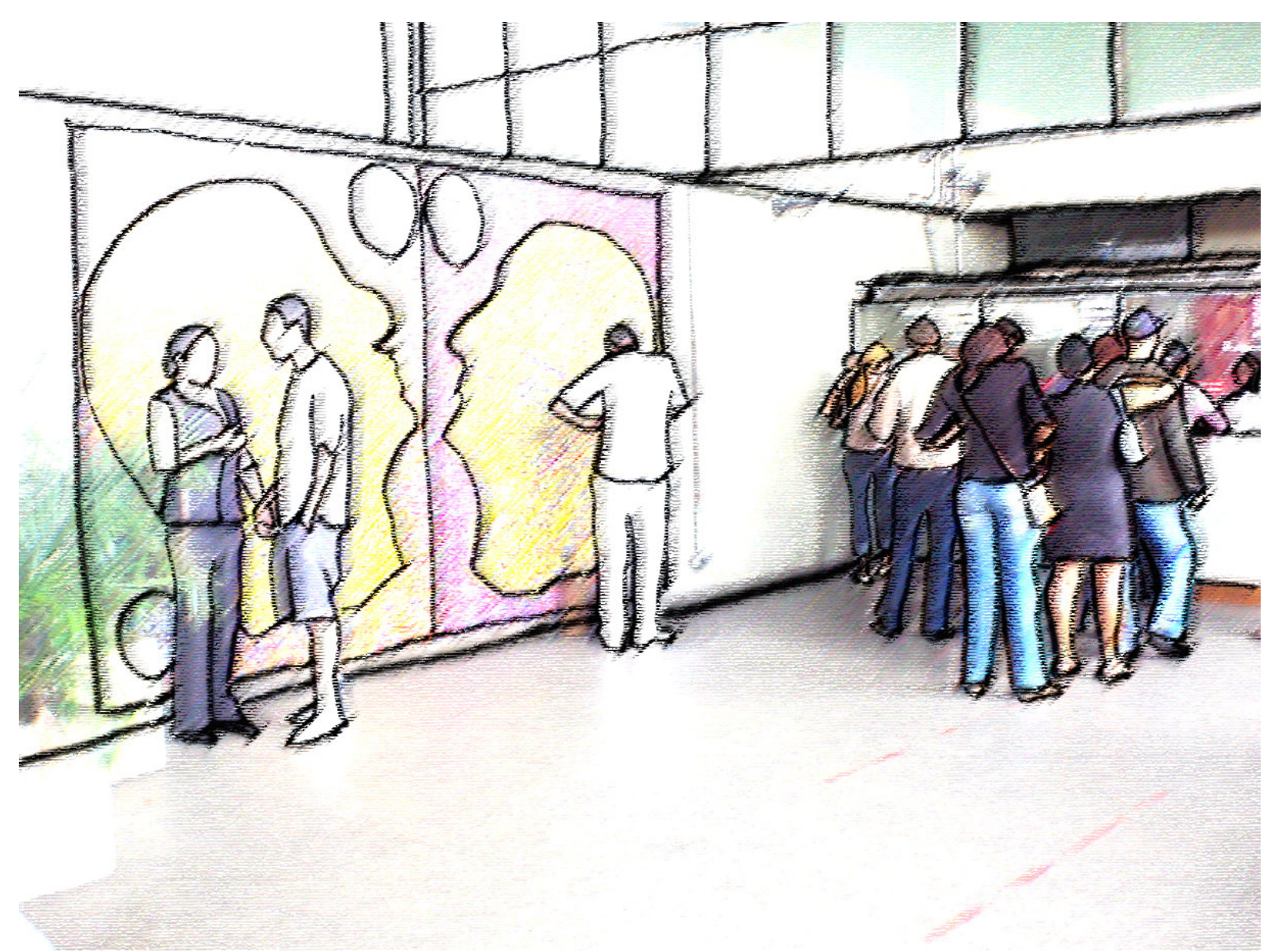

Figura 104 - Estação Santo André da Companhia Paulista de Trens Metropolitanos. (Ilustração da autora) 


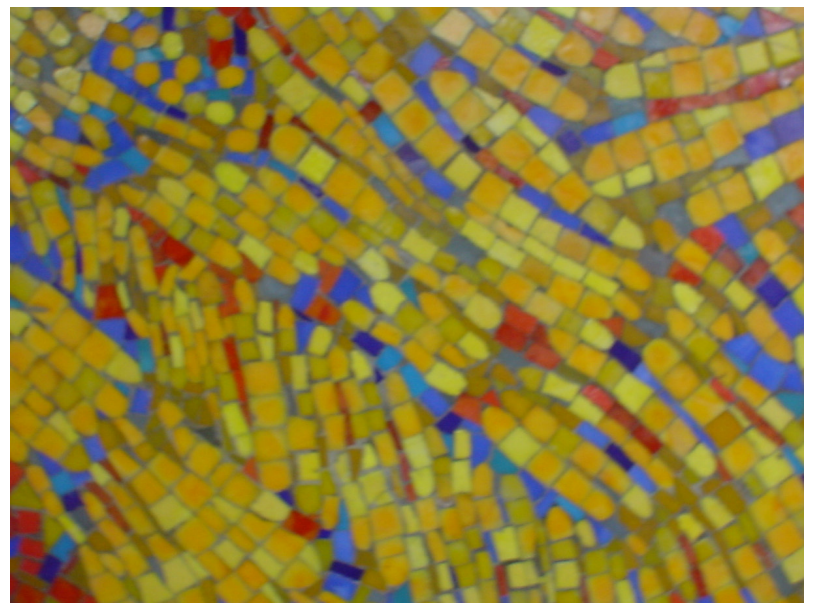

Figura 105 - Detalhe do mosaico de Flemming. (Foto da autora)

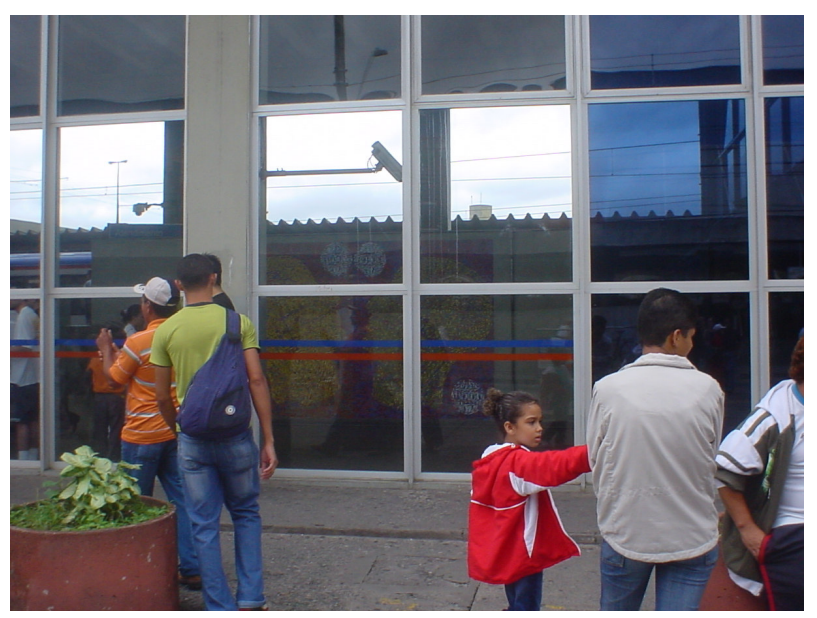

Figura 106 - Fachada de vidro da Estação Santo André, através da qual é possível ver o mosaico. (Foto da autora)
Um conjunto de dois mosaicos de Alex Flemming ocupa duas paredes da Estação Santo André da Companhia Paulista de Trens Metropolitanos. Ambos retratam duas cabeças de perfil. Chama a atenção o andamento das pastilhas que sugere músculos e tridimensionalidade e movimento.

A fachada de vidro da estação deveria ser favorável para a visualização da obra, mas isso não foi verificado pela autora, ainda que, segundo Sérgio Secches ${ }^{41}$, a situação chegou a ser pior, com vendedores ambulantes e película escura aplicada em todos os vidros, obstruindo completamente a visão.

Este é o único trabalho em mosaico de Flemming, que acha este trabalho, apesar de não ser uma de suas obras mais conhecidas, muito importante por causa da sua pesquisa sobre o material e a técnica. ${ }^{42}$ Ele afirmou também que gostaria de fazer mais mosaicos.

\footnotetext{
${ }^{41}$ Mosaicista que executou este trabalho, em conversa com a autora, jan/2007.

${ }^{42}$ Alex Flemming em conversa com a autora, jan/2007.
} 
- Alex Flemming (1954-).

- Endereço: Estação Santo André da Companhia Paulista de Trens Metropolitanos, Santo André, SP.

- Implantação: Duas paredes internas, uma delas junto à bilheteria.

- Uso do edifício: estação ferroviária.

- Data: 1992.

- Tema: cabeças.

- Assinatura: canto inferior direito.

- Transcrição da assinatura: ALEX FLEMMING.

- Execução: Vidrotil.

- Data da avaliação: dez/2006.
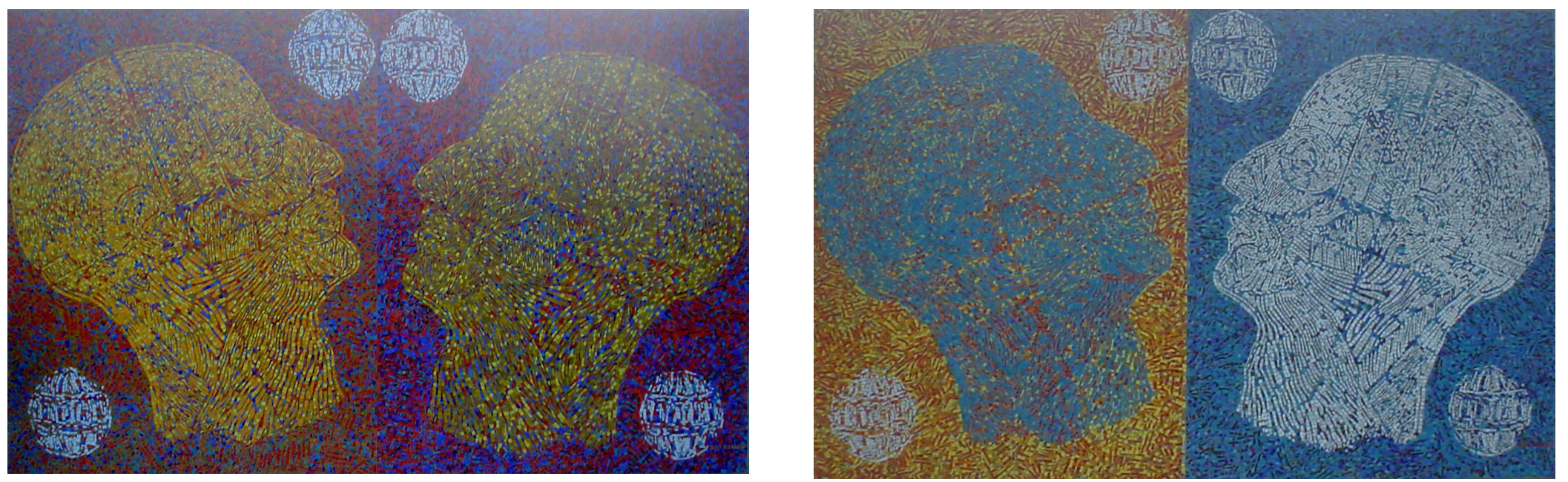

Figura 107 - Mosaicos de Alex Flemming da Estação Santo André. (Fotos da autora) 


\subsection{Cultura Inglesa Claudio Tozzi}

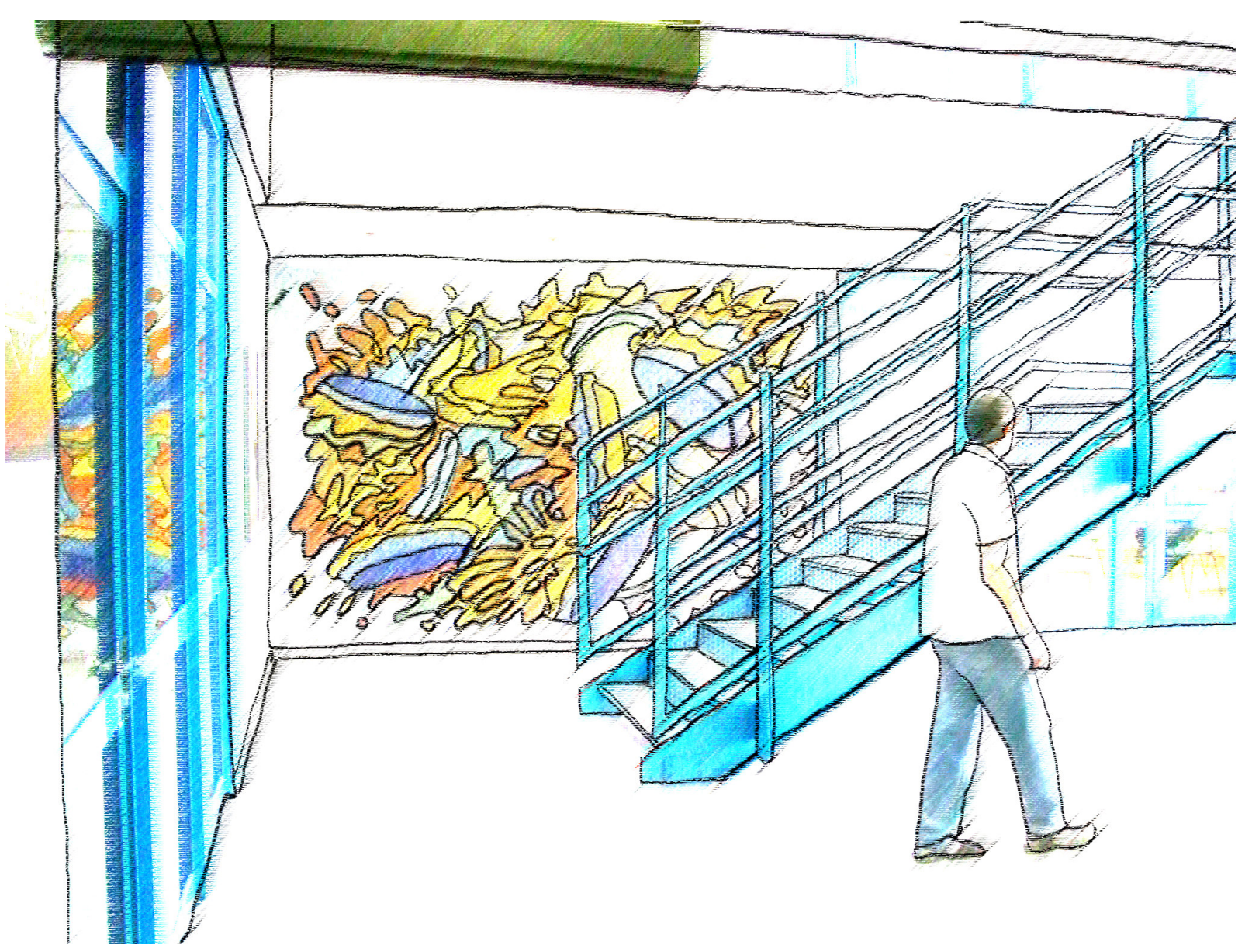

Figura 108 - llustração do ambiente com o mosaico Pastelão na Cultura Inglesa. (Ilustração da autora) 


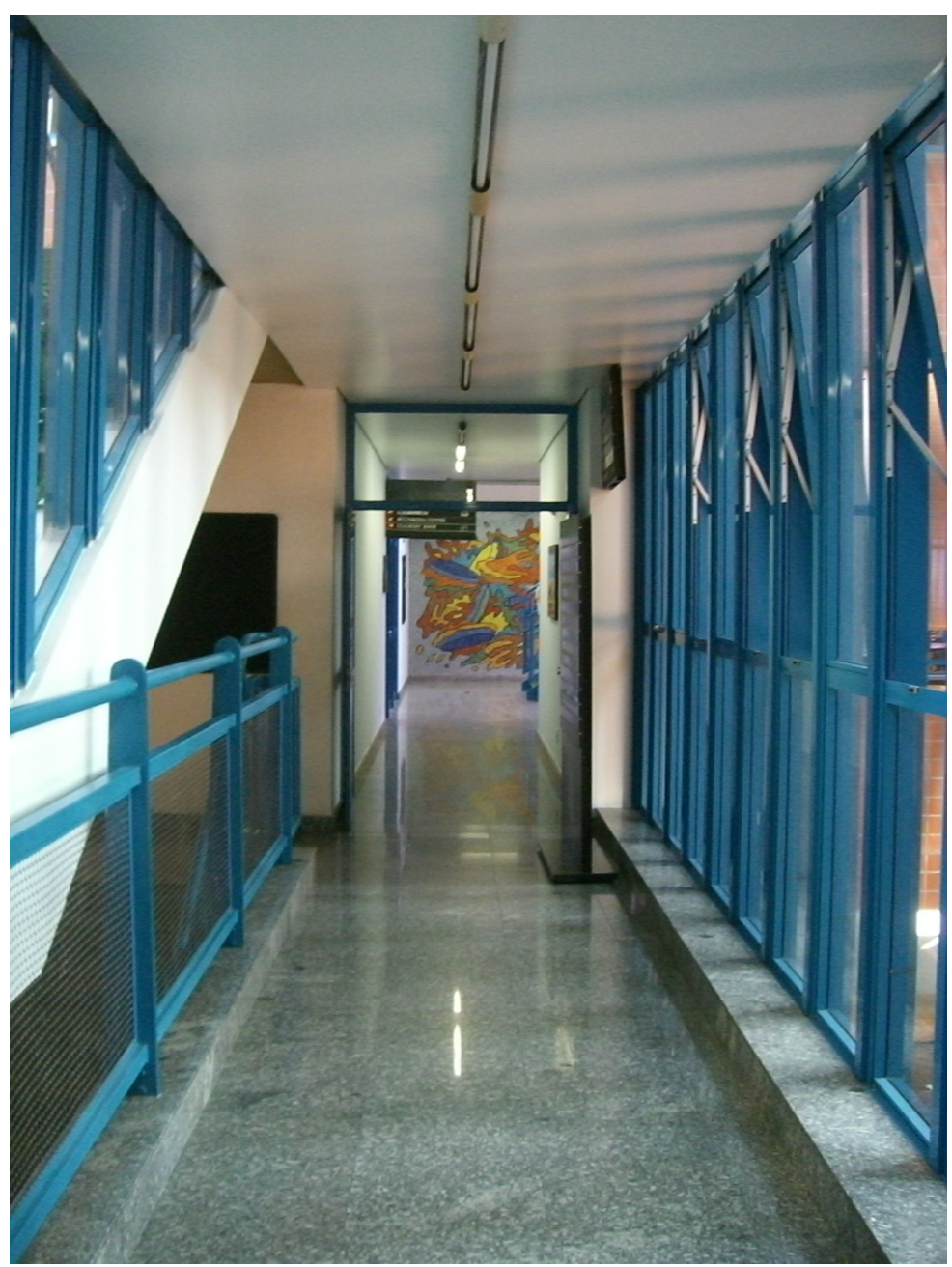

Figura 109 - Mosaico Pastelão visto a partir do corredor. (Foto da autora)
Ao entrar na Unidade Mooca da Cultura Inglesa, passa-se por uma recepção e segue-se um corredor que dá acesso às demais dependências da escola. Vê-se o mosaico multicolorido Pastelão ao fundo, logo que se começa a caminhar pelo corredor, mas não o se vê por completo, estimulando a curiosidade de vê-lo por inteiro e indicando a quem caminha que aquele ambiente lá adiante deve-se abrir.

Ao chegar ao fim do corredor vê-se o mosaico em um ambiente bem iluminado, também de circulação, onde se encontra uma abertura para o pavimento superior, uma escada de meta, e, ao lado do mosaico, a sala de multimídia que é separada por vidro.

Sendo visto de frente por quem chega ao ambiente, o mosaico Pastelão está em evidência. A escada no centro do ambiente obstrui parcialmente a visão do mosaico, mas não o desvaloriza ao fundo. Parece que o mosaico de cores intensas tem o que poderia ser agressivo cortado pela escada que tornou a disposição do mosaico leve e despretensiosa, provando que a obra de arte não precisa estar presente na arquitetura como um objeto de ostentação para destacar-se. 


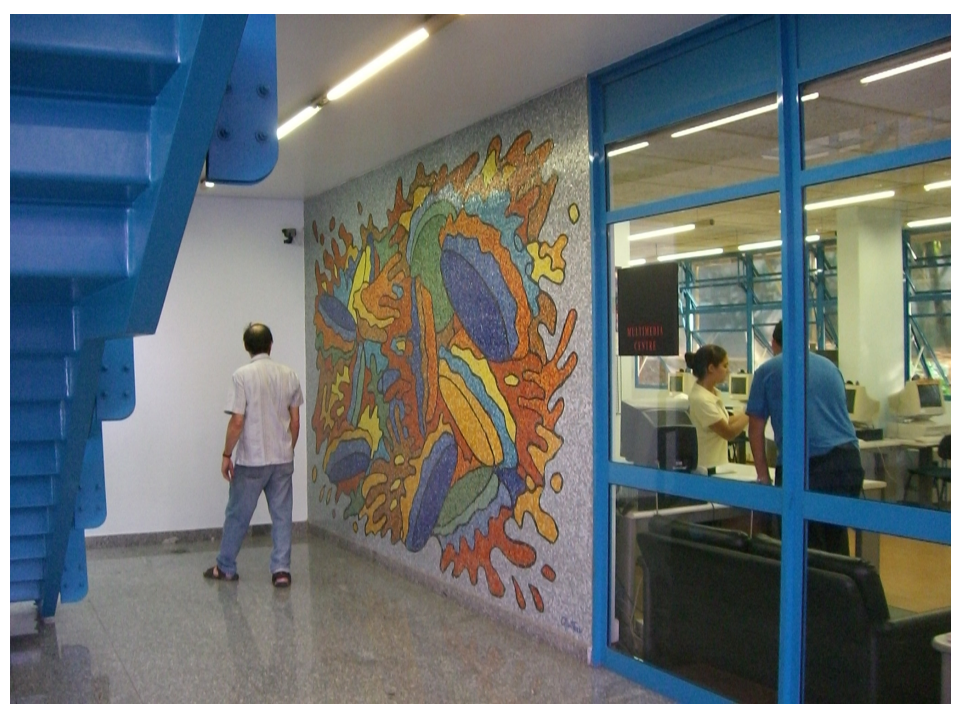

Figura 110 - Mosaico ocupando todo o plano da parede que é continuada apenas por vidro. (Foto da autora)
O mosaico foi executado com pastilhas cortadas em tamanho $1 \times 1 \mathrm{~cm}$. Nos planos preenchidos com cores variadas, estão pastilhas de vários tons de cada cor que preenche cada área, conferindo ao mosaico uma vibração cromática. Esse recurso também foi utilizado no fundo, pastilhas azul-claras misturadas às cinzas. Os planos são bem delimitados com linhas pretas, mas a presença de algumas pastilhas azuis torna a linha preta mais leve e mais próxima à linha preta do artista que não é contínua, mas composta por pontos, assim como seus planos.

Além do azul diluído em todo o mosaico, os elementos de metal, escada e esquadrias, presentes no ambiente, também são azuis, conferindo uma unidade à obra de arte junto à arquitetura. 


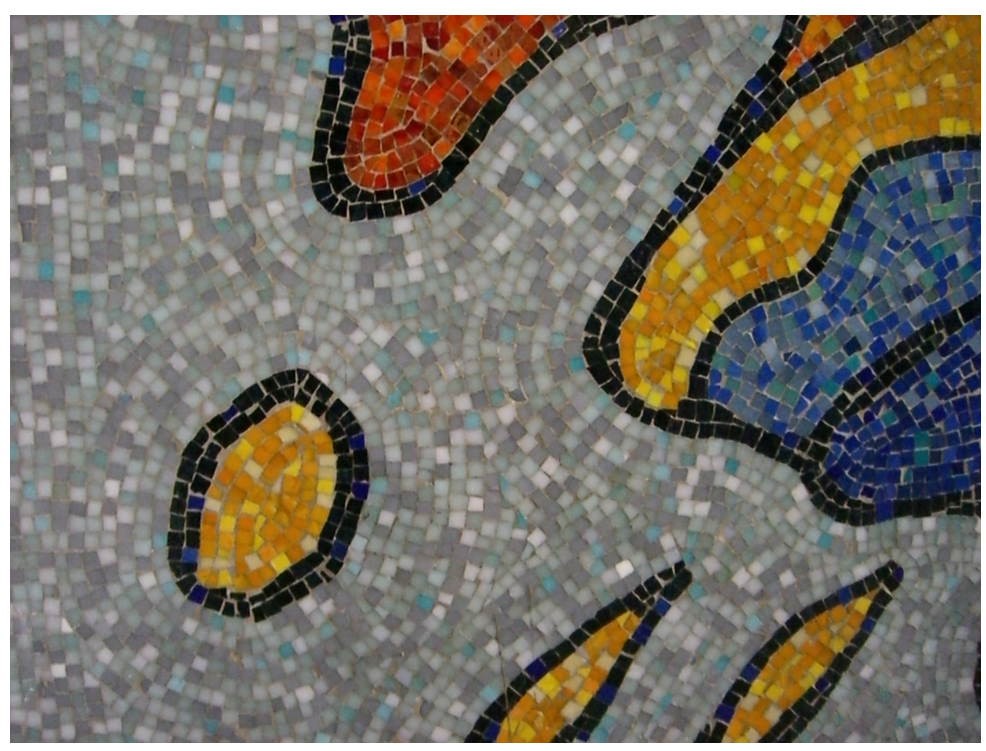

Figura 111 - Detalhe do mosaico Pastelão, onde é possível observar as pastilhas azuis nas linhas e no fundo. (Foto da autora)

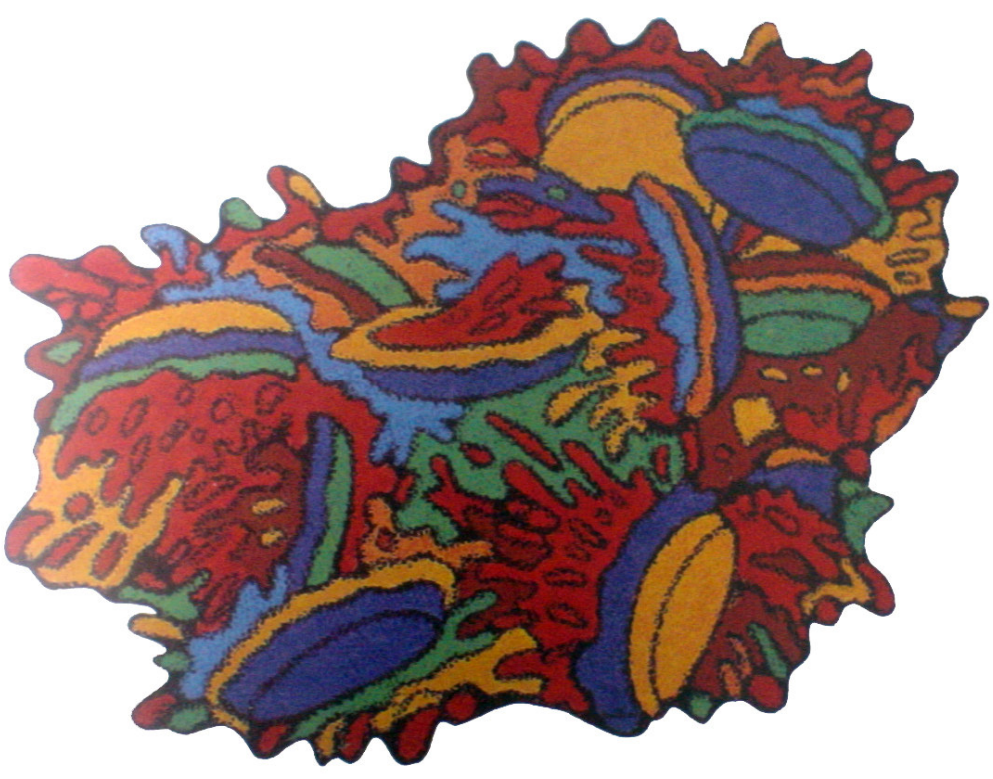

Figura 112 - Pastelão. Acrílico sobre tela colada em madeira recortada, $107 \times 145 \mathrm{~cm}$, 1985. (Fonte: KLINTOWITZ, Jacob. Claudio Tozzi: o universo construindo a imagem. Brasil: Valoart, 1989) 


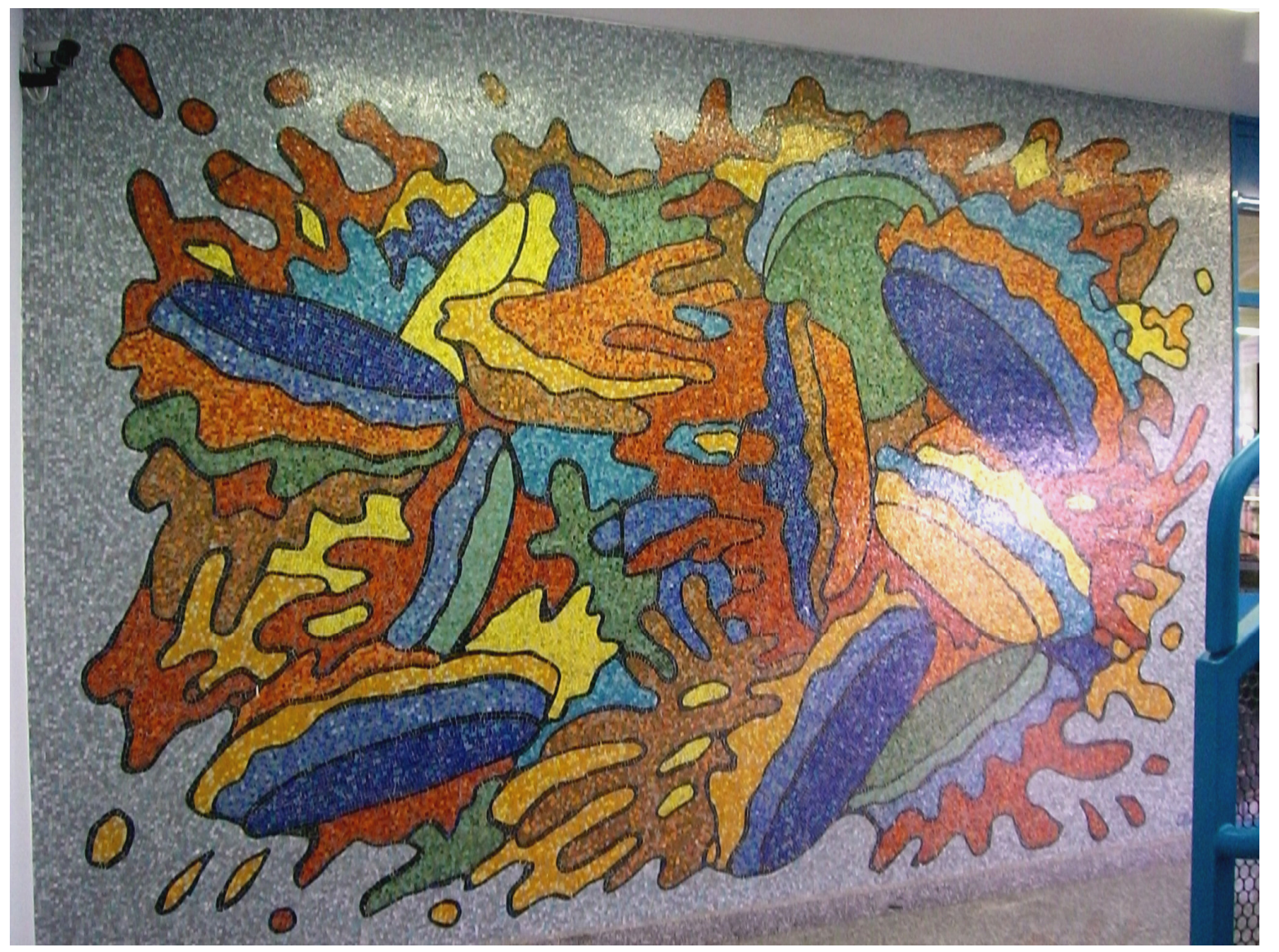

- Autor: Claudio Tozzi.

- Título: Pastelão.

- Endereço: Rua do Oratório, 232, São Paulo, SP.

- Implantação: Área de circulação junto à sala de multimídia.

- Uso do edifício: escola de inglês.

- Data: 1995.

- Tema: tortas em movimento. - Assinatura: canto inferior direito.

- Transcrição da assinatura:

Clau Tozzi.

- Execução: Vidrotil.

- Data da avaliação: jan/2007.

Figura 113 - Mosaico Pastelão. (Foto da autora) 


\subsection{Seguradora Porto Seguro}

Herton Roitman

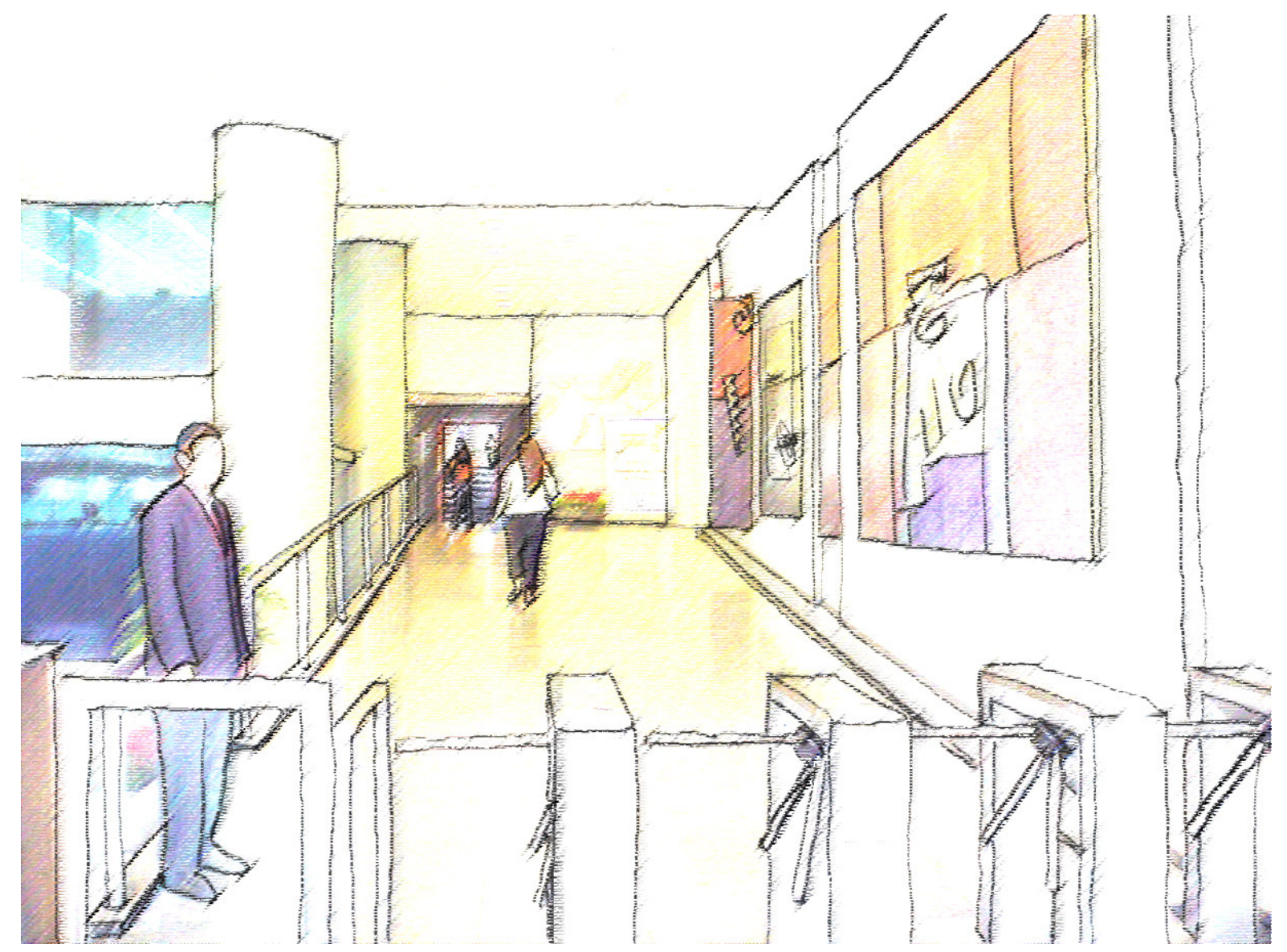

Figura 114 - Mosaicos de Herton Roitman na Seguradora Porto Seguro. (Ilustração da autora) 


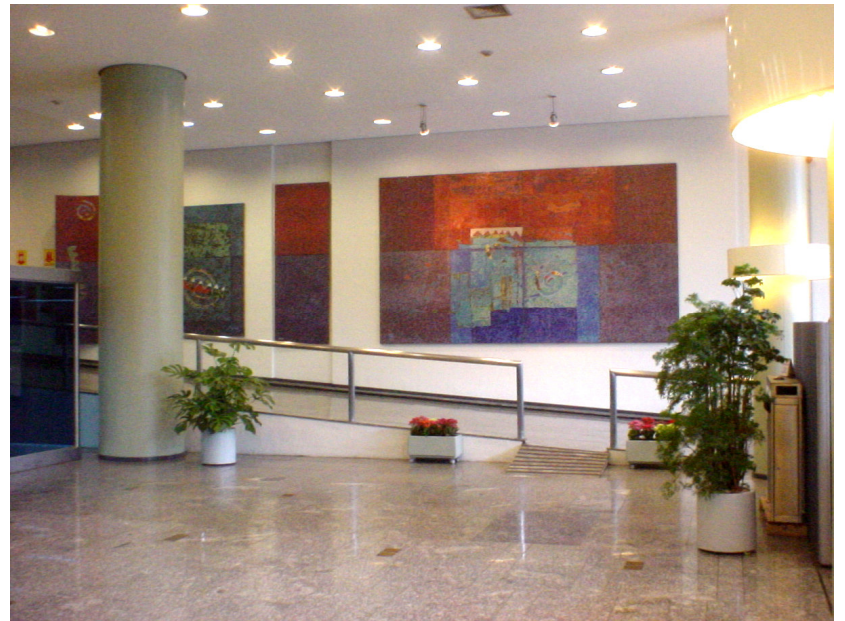

Figura 115 - Vista geral dos mosaicos na Porto Seguro. (Foto da autora)

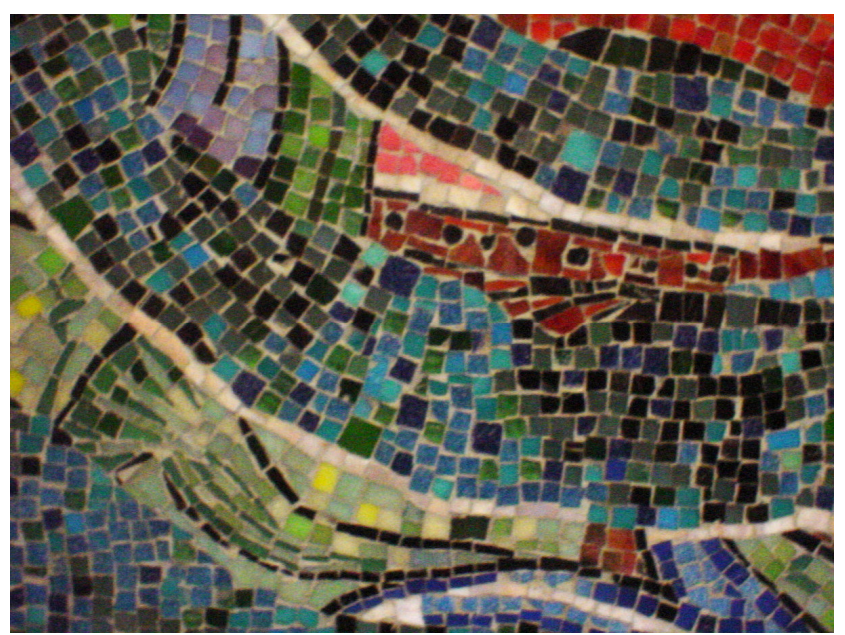

Figura 116 - Detalhe do primeiro painel, da esquerda para a direita. (Foto da autora)
Os mosaicos de Herton Roitman na Seguradora Porto Seguro estão em três painéis e uma escultura dispostos ao longo da parede, logo na entrada do edifício, ao lado de uma rampa. A execução dos mosaicos em painéis deveu-se à vontade do cliente poder, caso saia daquele endereço um dia, levar o mosaico consigo. Porém, percebe-se claramente, pela disposição dos painéis, que aquele conjunto foi planejado para o local.

Os três painéis e a escultura são divididos, em alturas variadas, por uma linha horizontal, e estão dispostos de modo que essa linha mantenha o mesmo nível, embora a altura da base e do topo das peças varie. Essa disposição garante a unidade do conjunto, preso a essa linha, e ao mesmo tempo permite a variedade de formas e tamanhos, o que torna $o$ conjunto mais leve e estimulante. Por se tratar de uma área de circulação, esta solução está de acordo com a sucessão de surpresas que Gordon Cullen defende e define como visão serial. ${ }^{43} \mathrm{Se}$ as peças estivessem alinhadas pelo topo e pela base, a tendência seria o conjunto tornar-se monótono.

\footnotetext{
${ }^{43}$ CULLEN, Gordon. Paisagem Urbana. Lisboa: Edições 70, 1996. p. 11.
} 
A escultura, último elemento visto por quem sobe a rampa, também é presa à parede assim como os painéis. Além de participar dando movimento, ela também tem a função de "esconder" o equipamento de combate a incêndio.

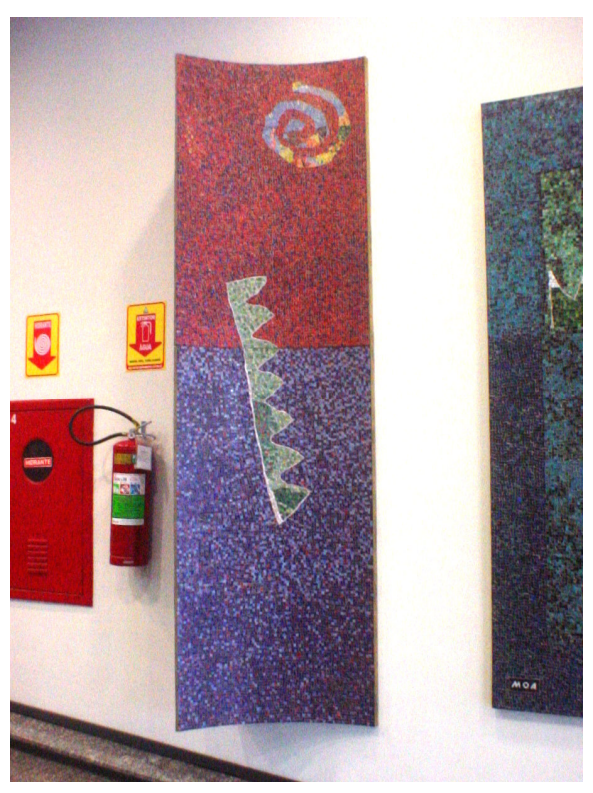

Figura 117 - Escultura vista pelo lado direito. (Foto da autora)

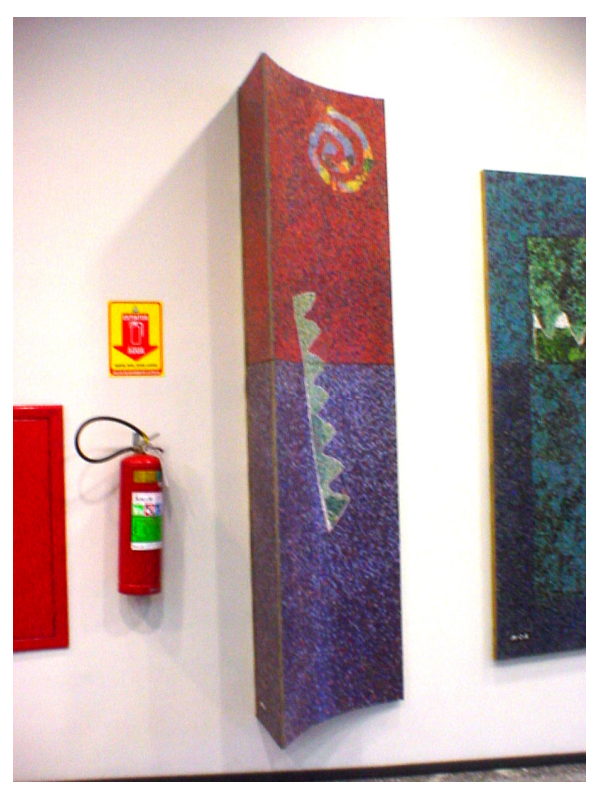

Figura 118 - Escultura vista de frente. (Foto da autora)

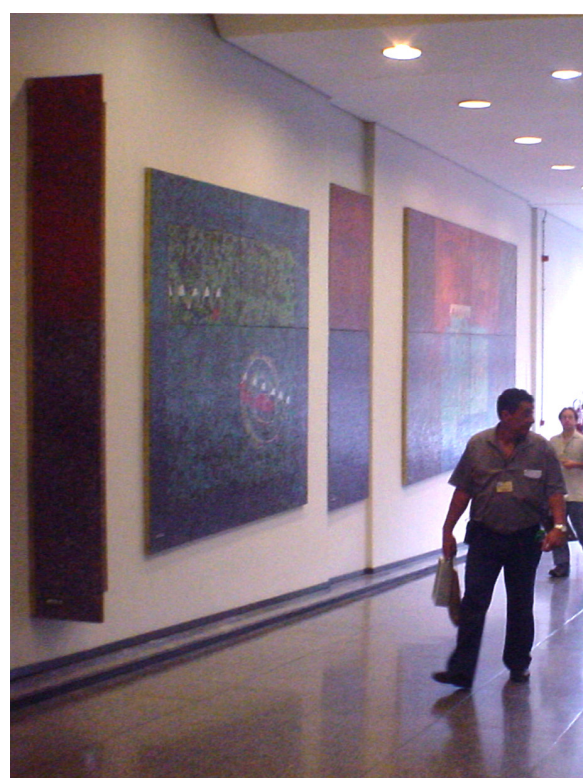

Figura 119 - Escultura vista pelo lado esquerdo e os três painéis. (Foto da autora) 


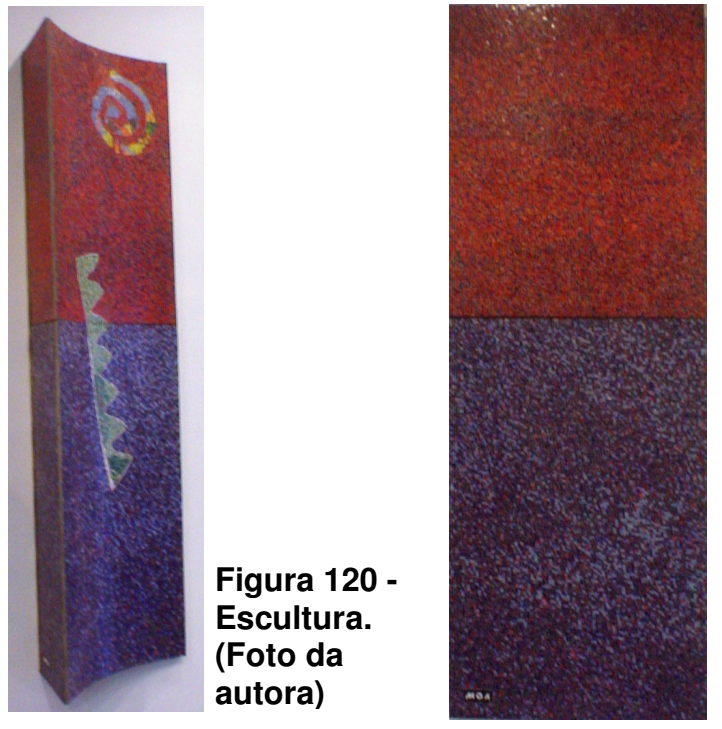

Figura 121 -

Segundo painel,

da esquerda

para a direita

(Foto da autora.)
- Autor: Herton Roitman (1943-).

- Endereço: Av. Rio Branco, 1489, São Paulo, SP.

- Implantação: Parede interna junto à rampa.

- Uso do edifício: seguradora.

- Data: 1995/96.

- Tema: abstrato.

- Dimensões: (da esquerda para a direita) uma escultura $3 \times 0,7 \times 0,4 \mathrm{~m}$ e três painéis, $2,5 \times 2,5 \mathrm{~m}$, 3x1m e $3 \times 4,8 \mathrm{~m}$.

- Assinatura: canto inferior direito de todos os objetos (também consta a assinatura do ateliê de mosaicos "MOA" no canto inferior esquerdo do primeiro e segundo painel e na face posterior da escultura).

- Transcrição da assinatura: na escultura e no segundo painel HR 96, no primeiro painel H Roitman 96 e no terceiro painel H Roitman 95.

- Execução: Mosaico Objeto de Arte.

- Data da avaliação: dez/2006.

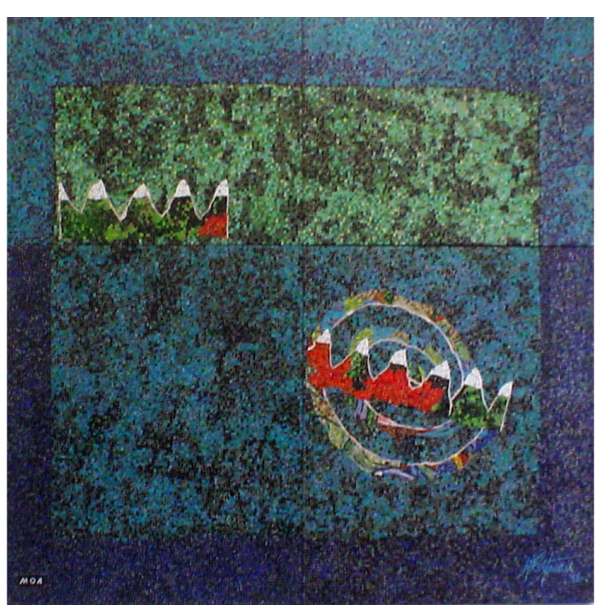

Figura 122 -

Primeiro

painel. (Foto

da autora)

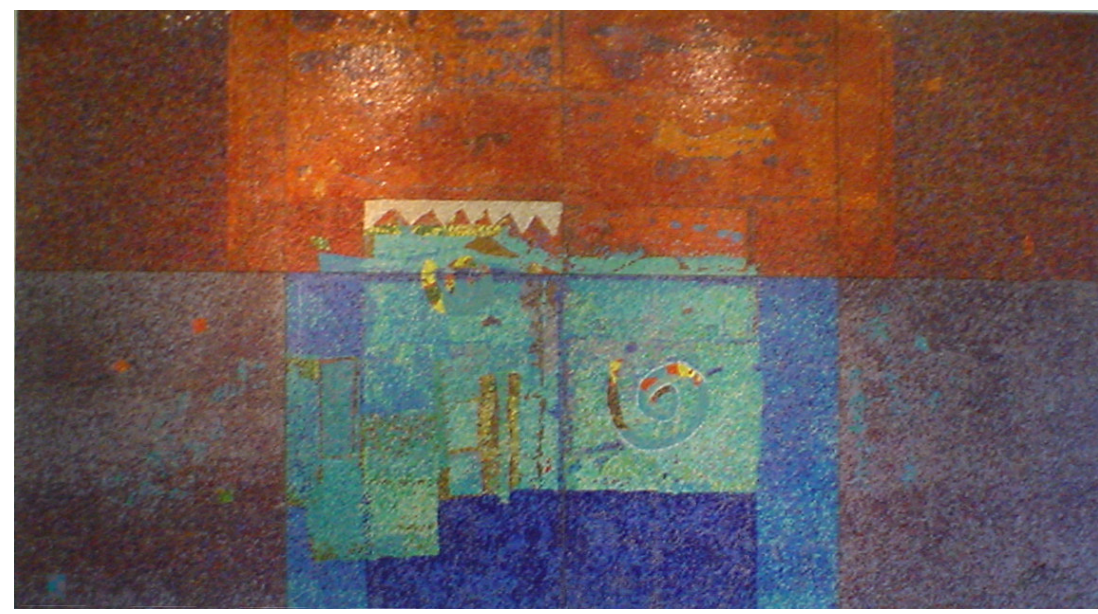

Figura 123 -

Terceiro

painel. (Foto da autora) 


\subsection{Centro Cultural Dragão do Mar}

Aldemir Martins

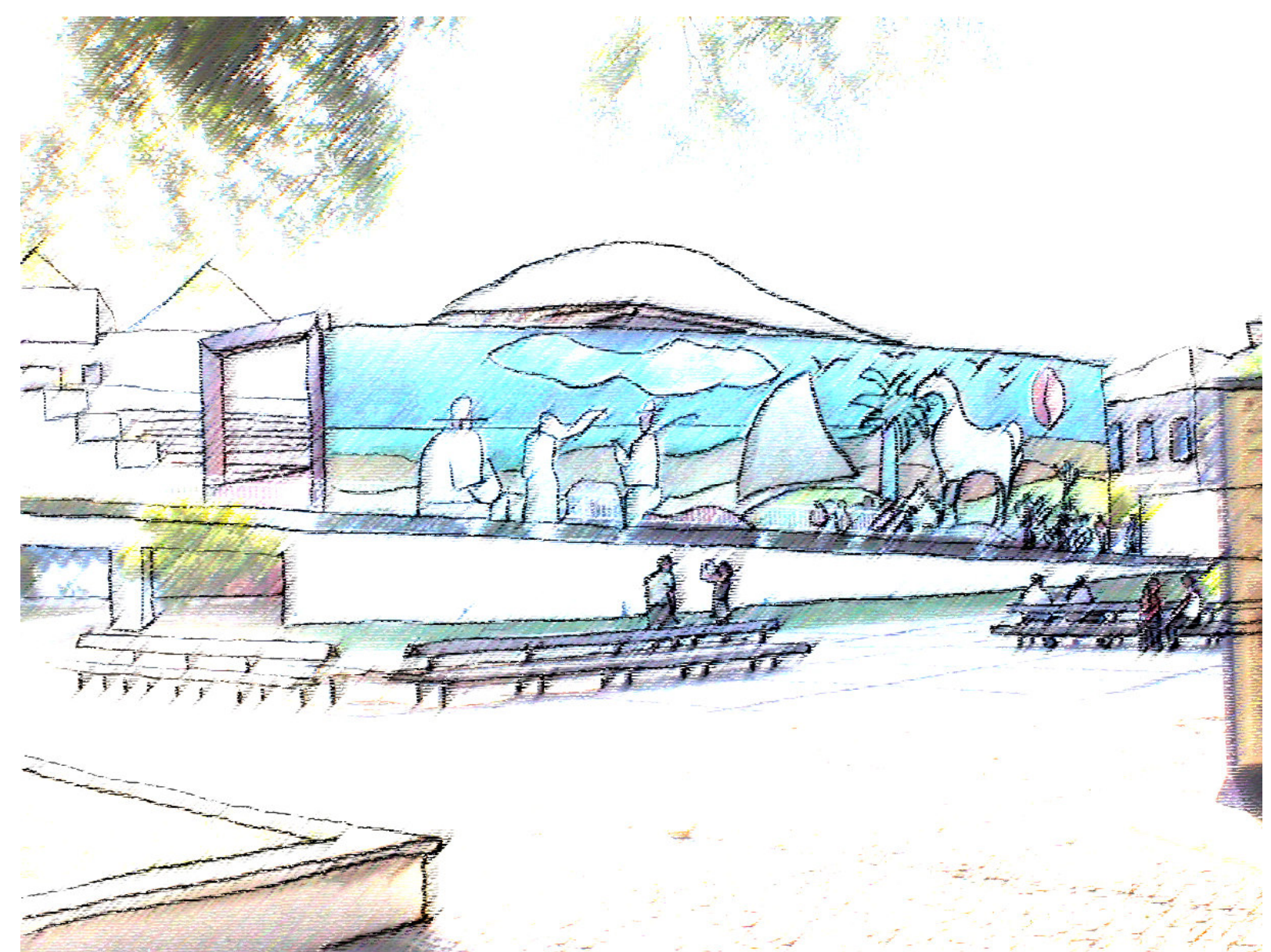

Figura 124 - Anfiteatro do Centro Cultural Dragão do Mar. (llustração da autora) 


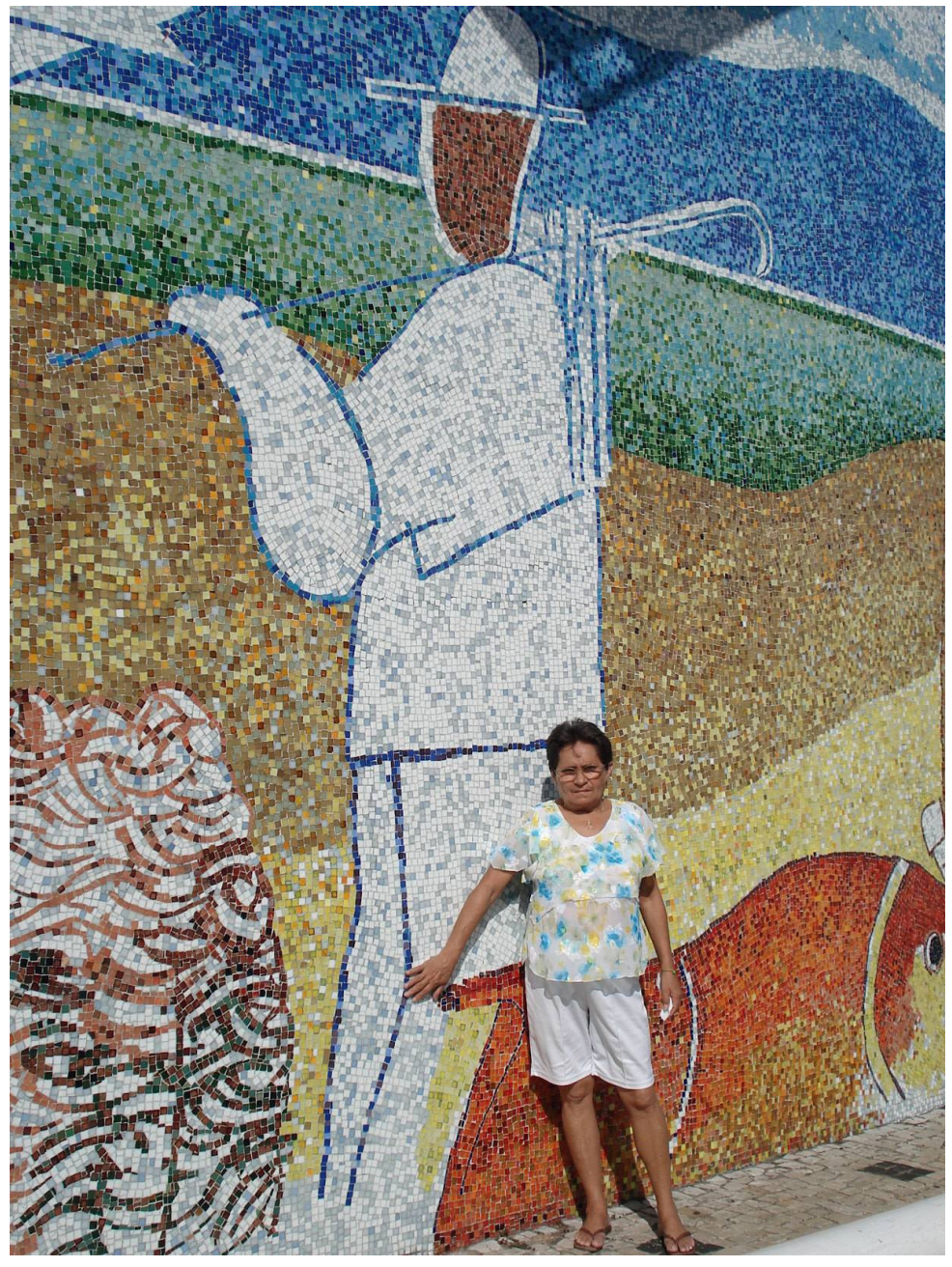

Figura 125 - Detalhe do mosaico. (Foto de Rosa Cecília Teixeira)
O mural encontra-se na parede externa de um anfiteatro no Centro Cultural Dragão do Mar em Fortaleza, CE. A parede é curva e fica no fundo do palco voltado para uma grande praça. O tema é figurativo, o mural apresenta uma paisagem com elementos do Ceará, a terra natal de Aldemir Martins, como o mar com a jangada, mandacarus, peixes, cajus e outras frutas.

Por ter grandes dimensões, ser horizontal e retratar uma paisagem, ele dá uma sensação de profundidade, como se a enorme superfície que está ali não fosse uma barreira, mas um espaço aberto que vai muito além, mais precisamente, até o horizonte que aparece na figura.

A rampa permite o acesso do observador junto ao mural, possibilitando a visão de detalhes que ficam no nível da vista, como os mandacarus, os cajus, o peixe e a assinatura. Esses elementos em escala menor do que 0 restante da composição estimula o olhar de perto e o toque. O público é motivado a ver de perto o mural que viu de longe e ele passa a perceber os elementos básicos do mosaico, as 


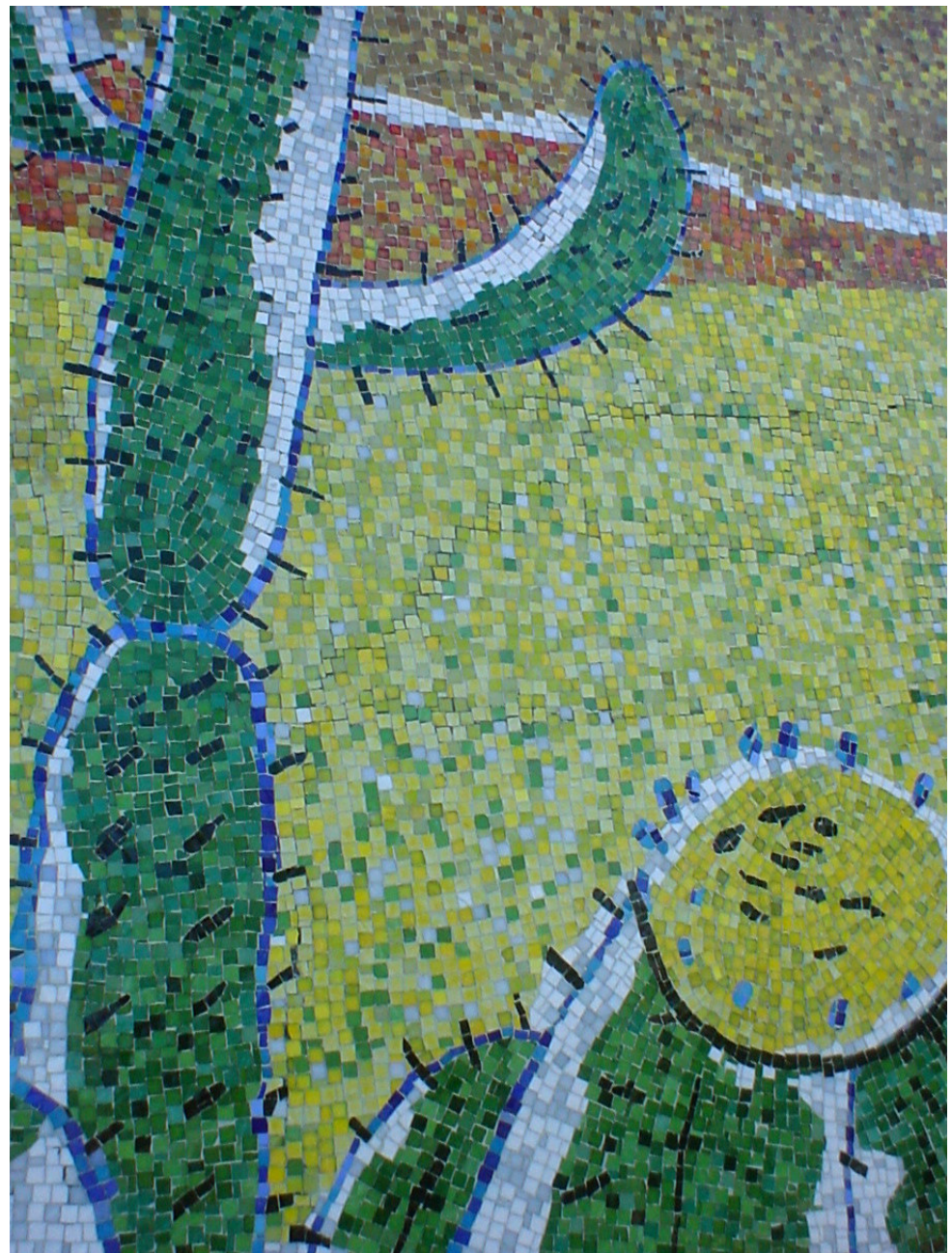

Figura 126 - Detalhe do mosaico, (Foto da autora) pastilhas, com suas cores muito variadas, o brilho do vidro, a textura e o andamento.

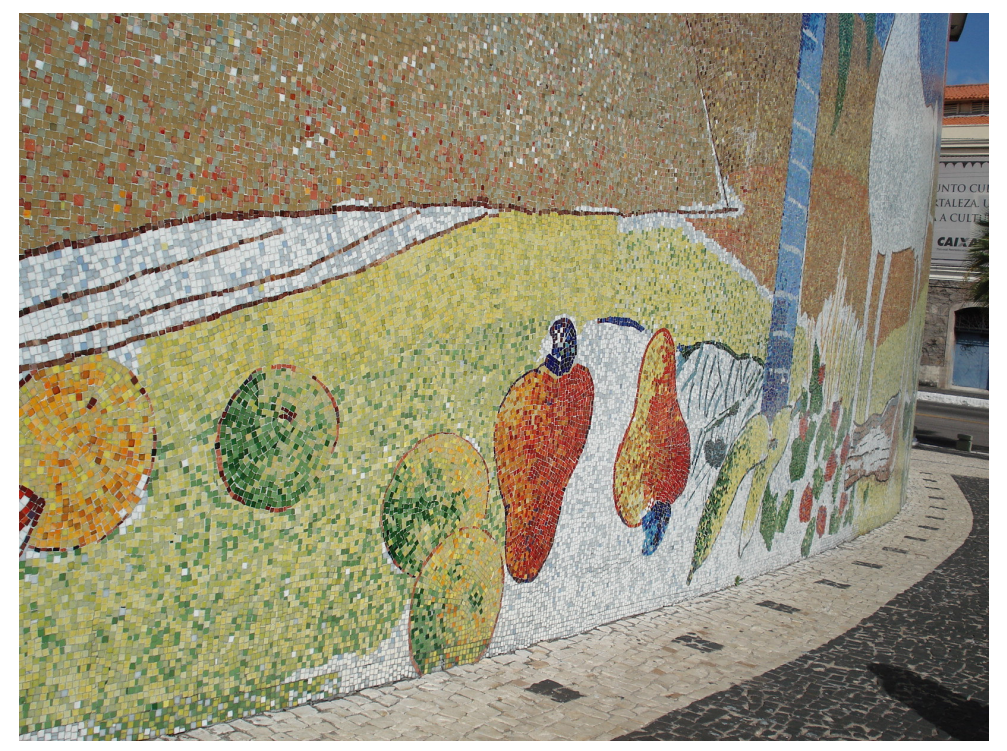

Figura 127 - Detalhe do mosaico junto à rampa. (Foto de Rosa Cecilia Teixeira) 
- Autor: Aldemir Martins (1922-2006)

- Arquitetos: Delberg Ponce de Leon e Fausto Nilo

- Endereço: Praça Almirante Saldanha, Fortaleza, CE.

- Implantação: Parede externa de um anfiteatro em uma praça.

- Uso do edifício: anfiteatro.

- Data: 1998.

- Tema: Figurativo - elementos da região.

- Dimensões: 7x27m (aprox.).

- Assinatura: canto inferior esquerdo.

- Transcrição da assinatura: Ademir Martins 98

- Execução: Vidrotil.

- Data de avaliação: out / 2005.

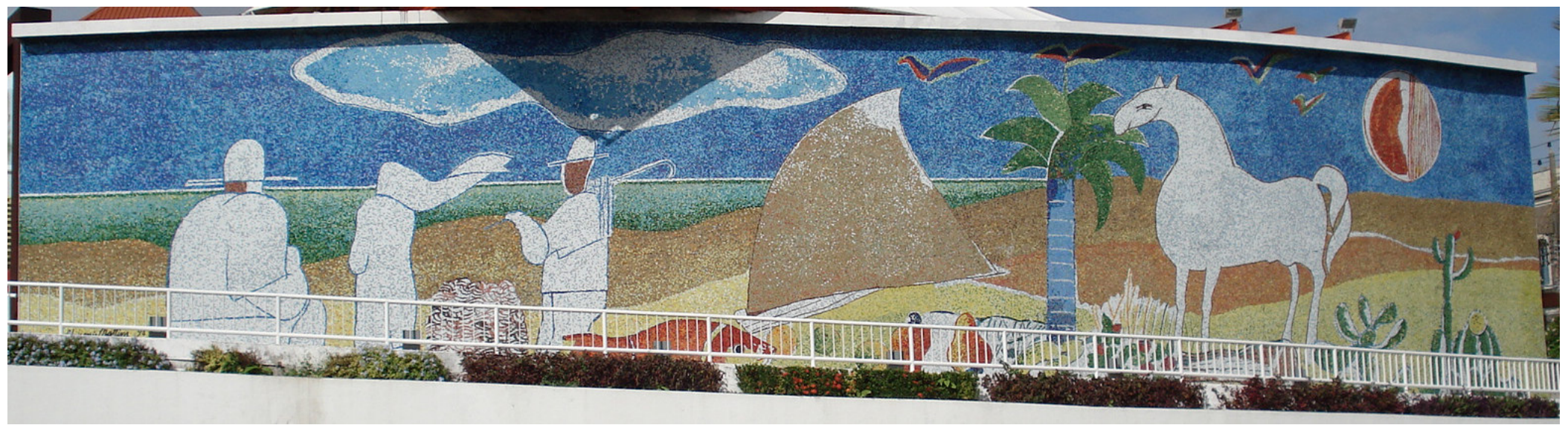

Figura 128 - Mosaico de Aldemir Martins do Centro Cultural Dragão do Mar. (Foto de Rosa Cecília Teixeira) 


\subsection{Novotel}

Claudio Tozzi

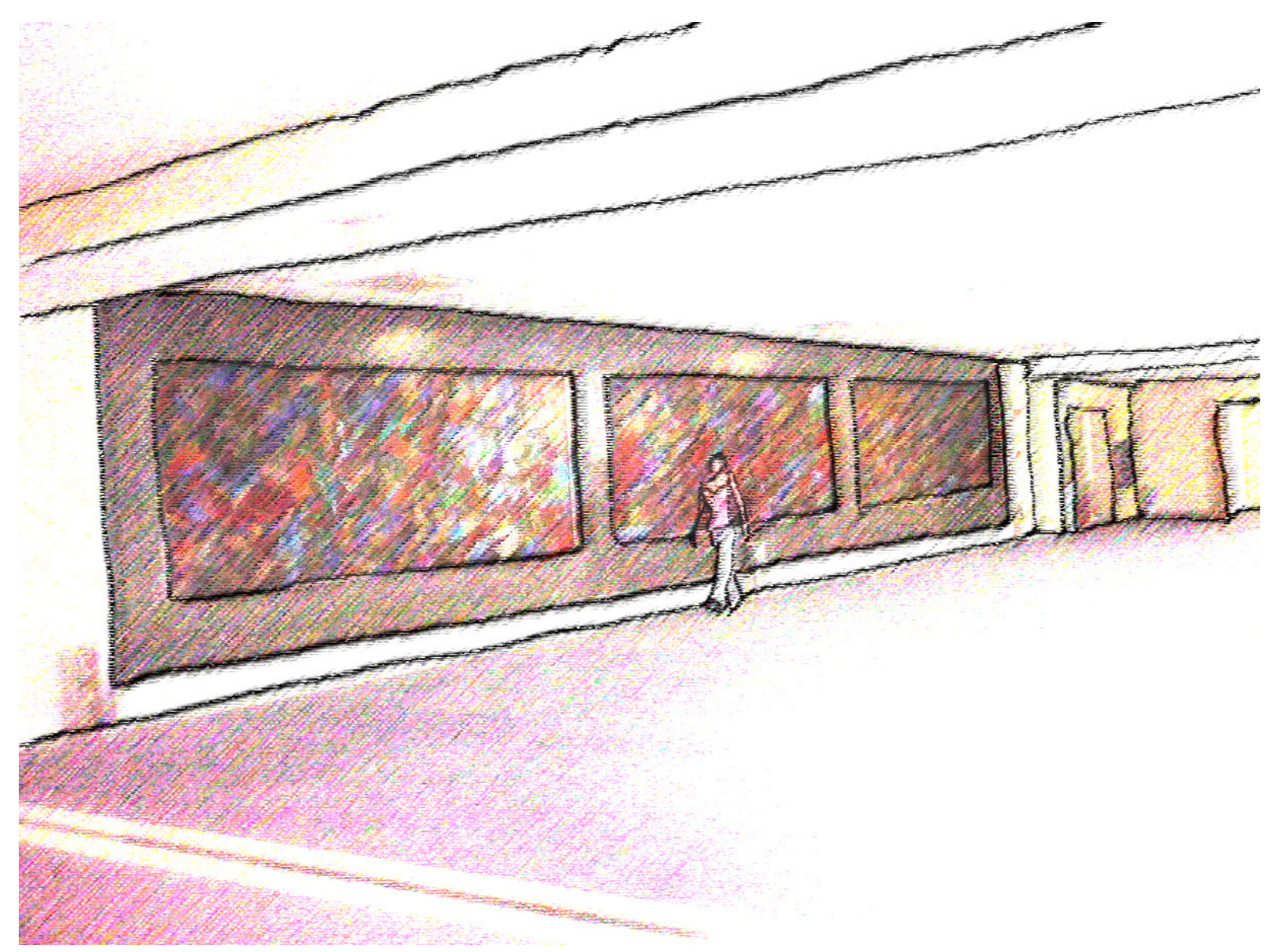

Figura 129 - Área de circulação do Novotel. (Ilustração da autora) 


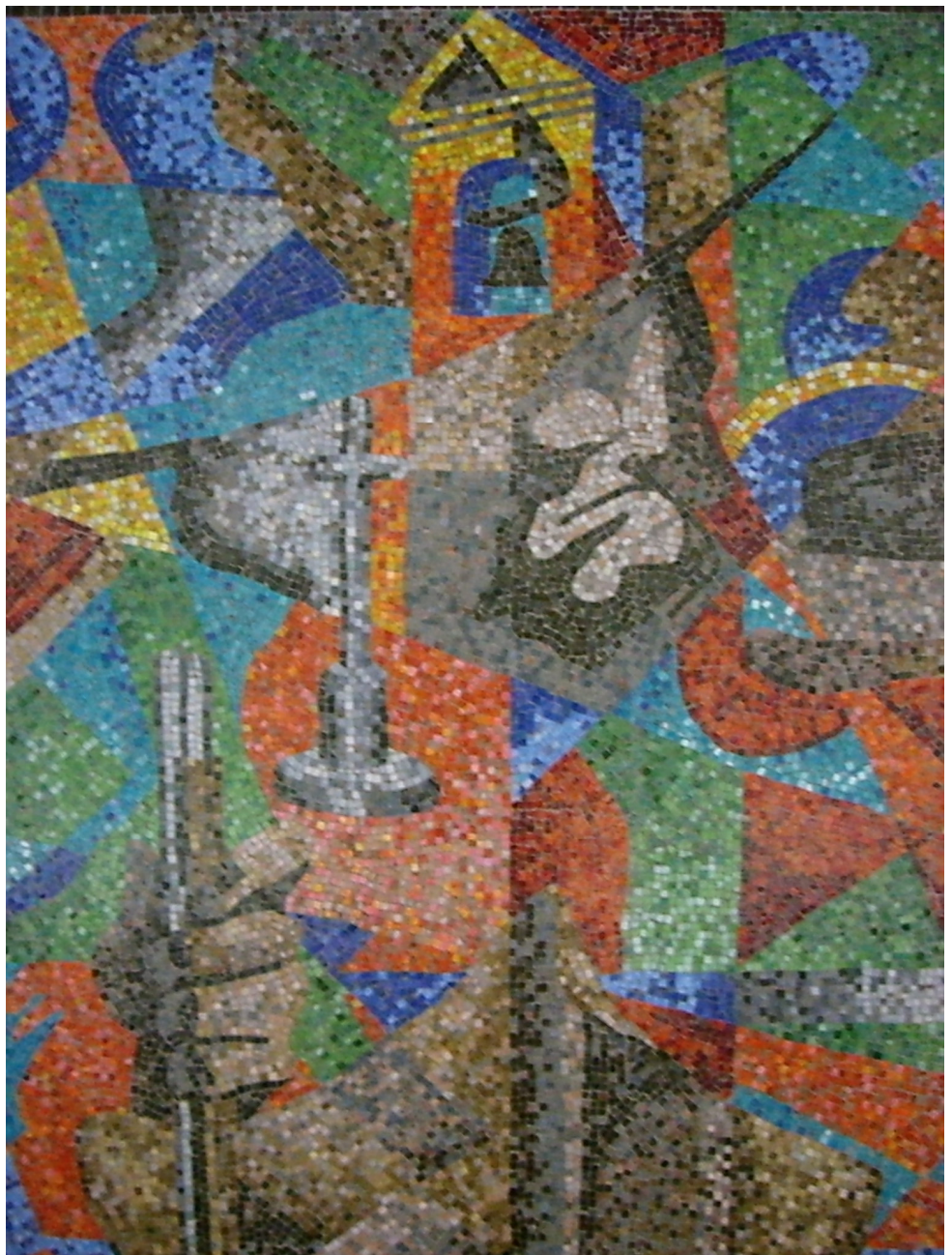

Figura 130 - Detalhe do mosaico retratando bandeirantes do Novotel. (Foto da autora)
O Novotel conta com dois mosaicos de Claudio Tozzi: o primeiro, que retrata bandeirantes, está em uma área de circulação, executado em 2000; o segundo, com palmeiras, junto à piscina, em 2001.

Como mosaico, o dos bandeirantes é muito rico pelos seus detalhes, e, principalmente pela composição das cores, mas se encontra em um local com iluminação, tanto a natural, quanto a artificial, precária, o que dificulta sua visualização.

Já o que retrata palmeiras encontra-se em uma situação bastante favorável, com farta luz natural. Em uma parede que, sem uma intervenção, pareceria perto demais da piscina, o mosaico dá uma continuidade à sua superfície azul de água se estendendo até a linha do horizonte, também de água no desenho, criando paisagem em um plano completamente integrada ao espaço diante dele. Além da própria composição, o degradê foi um recurso decisivo para conferir profundidade ao painel. 


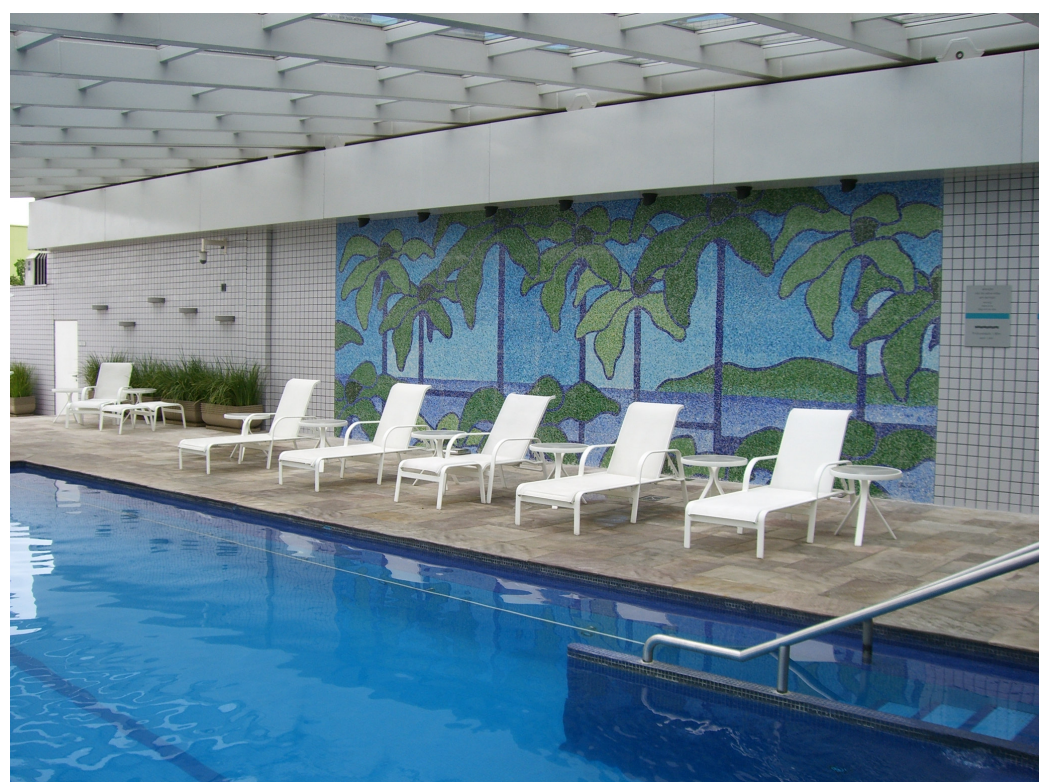

Figura 131 - Piscina do Novotel. (Foto da autora)

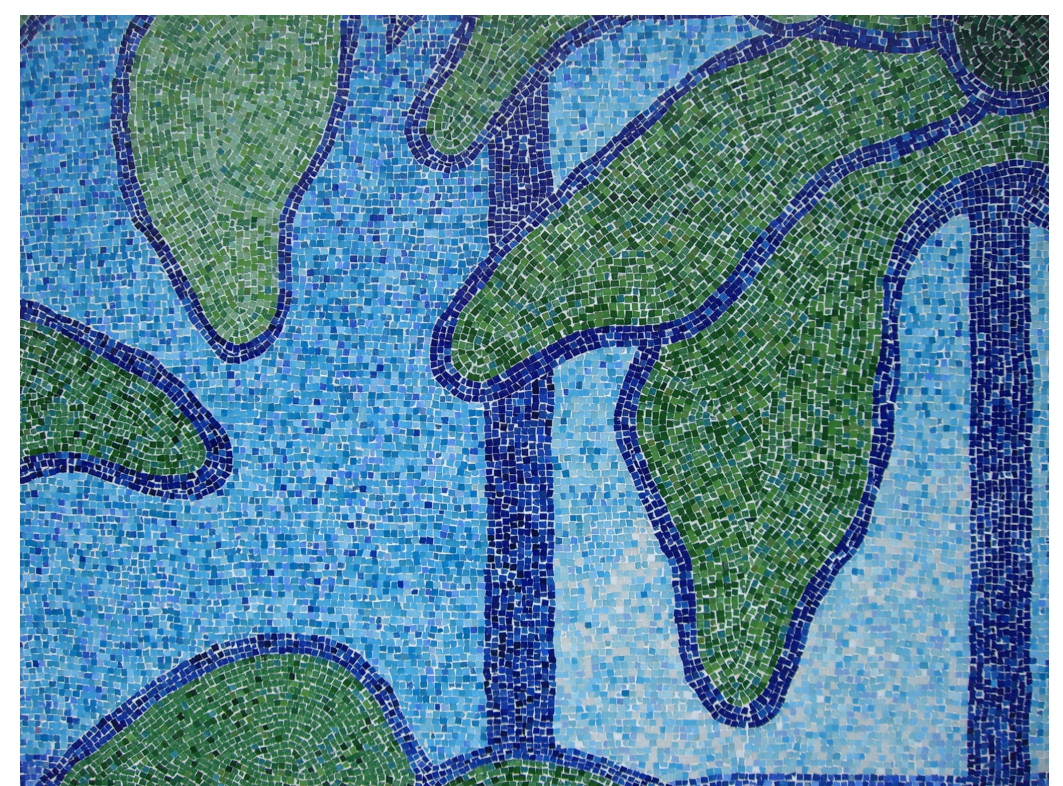

Figura 132 - Detalhe do mosaico junto à piscina do Novotel. (Foto da autora) 


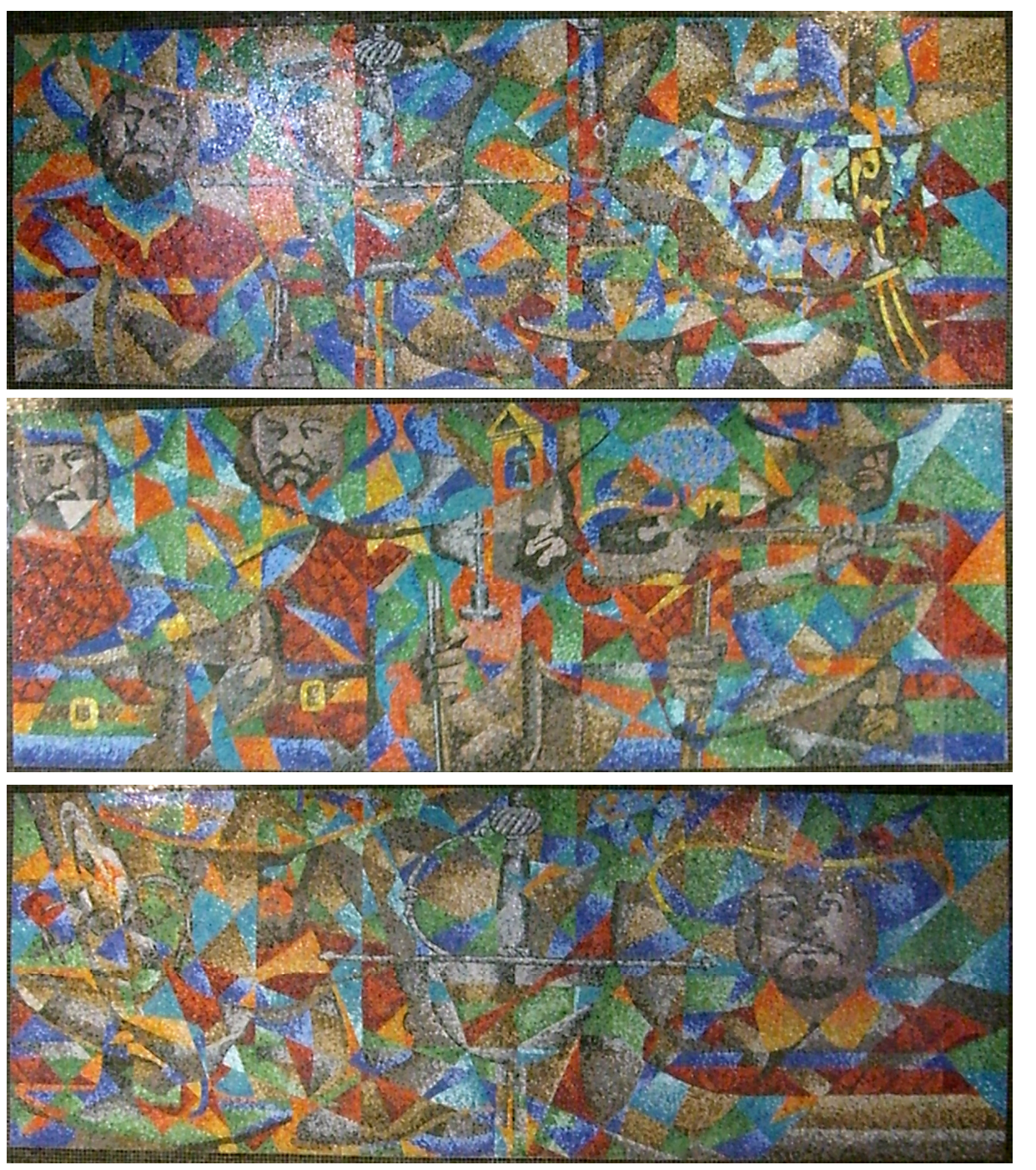

- Autor: Claudio Tozzi (1944-).

- Endereço: Av. Zaki Narchi, 500, São Paulo, SP.

- Implantação: Parede interna em área de circulação.

- Uso do edifício: hotel.

- Data: 2000.

- Tema: bandeirantes.

- Dimensões: três painéis de175x470cm.

- Assinatura: canto inferior direito.

- Transcrição da assinatura: Clau Tozzi.

- Execução: Mosaico Objeto de Arte.

- Data da avaliação: jan/2007.

Figura 133 - Os três painéis de Claudio Tozzi com tema de bandeirantes no Novotel. (Fotos de Peter Caplan) 
- Autor: Claudio Tozzi (1944-).

- Endereço: Av. Zaki Narchi, 500, São Paulo, SP.

- Implantação: parede junto à piscina.

- Uso do edifício: hotel.

- Data: 2001.

- Tema: palmeiras.

- Dimensões: 320x850 cm

- Assinatura: canto inferior direito.

- Transcrição da assinatura: Clau Tozzi.

- Execução: Mosaico Objeto de Arte.

- Data da avaliação: jan/2007.

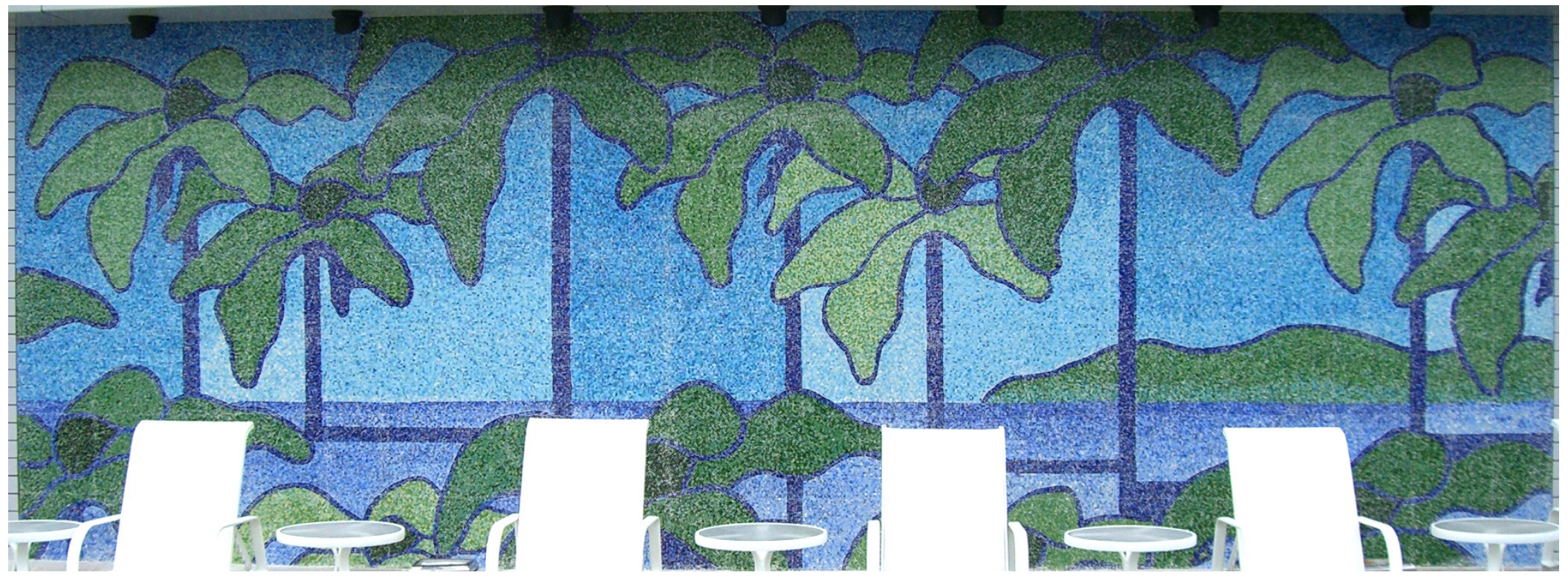

Figura 134 - Mosaico de Claudio Tozzi junto à piscina do Novotel. (Foto da autora) 


\subsection{Terminal de ônibus de Santo Amaro}

Odiléa Toscano

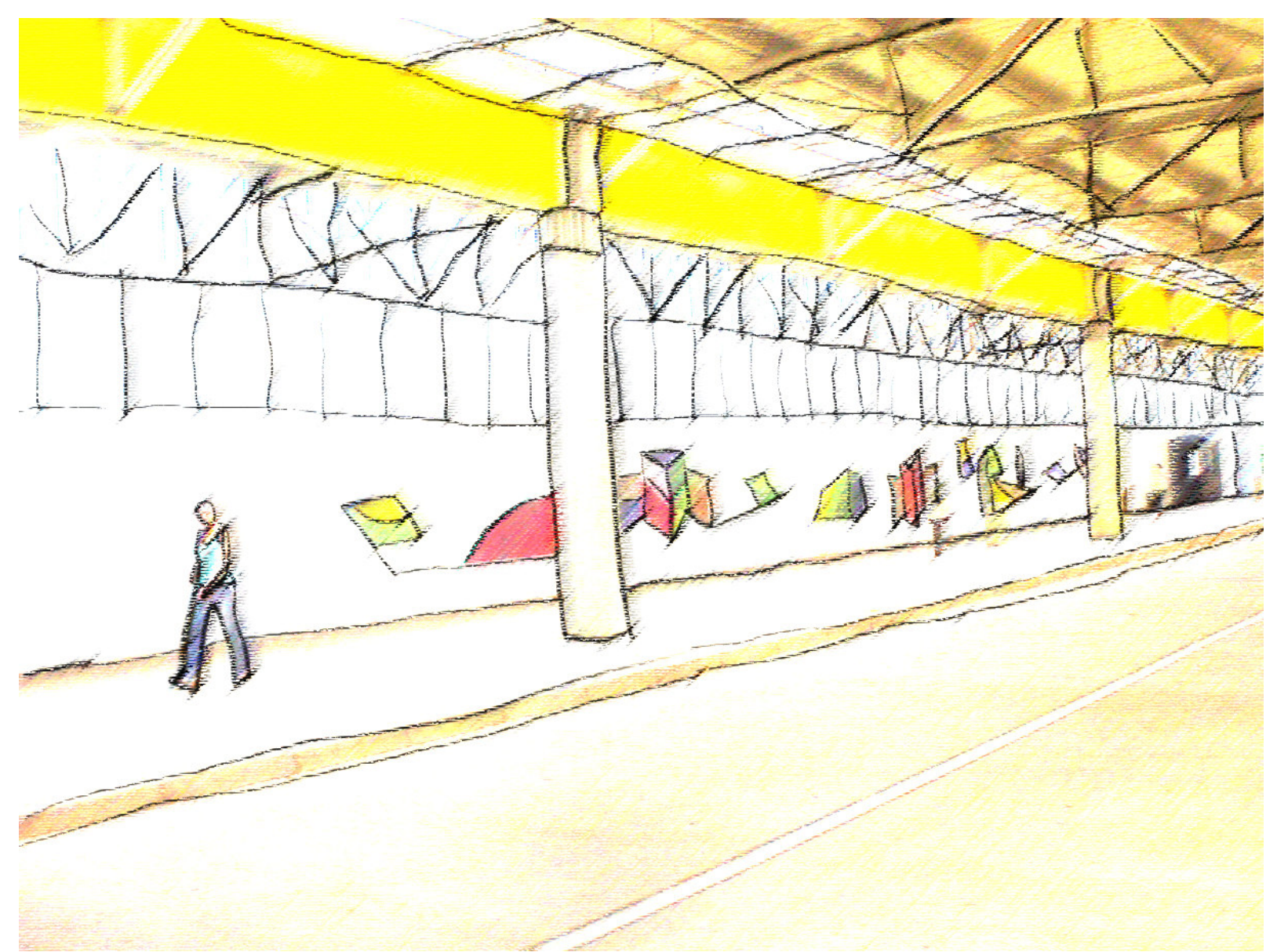

Figura 135 - Terminal de ônibus da Estação Santo Amaro. (llustração da autora) 


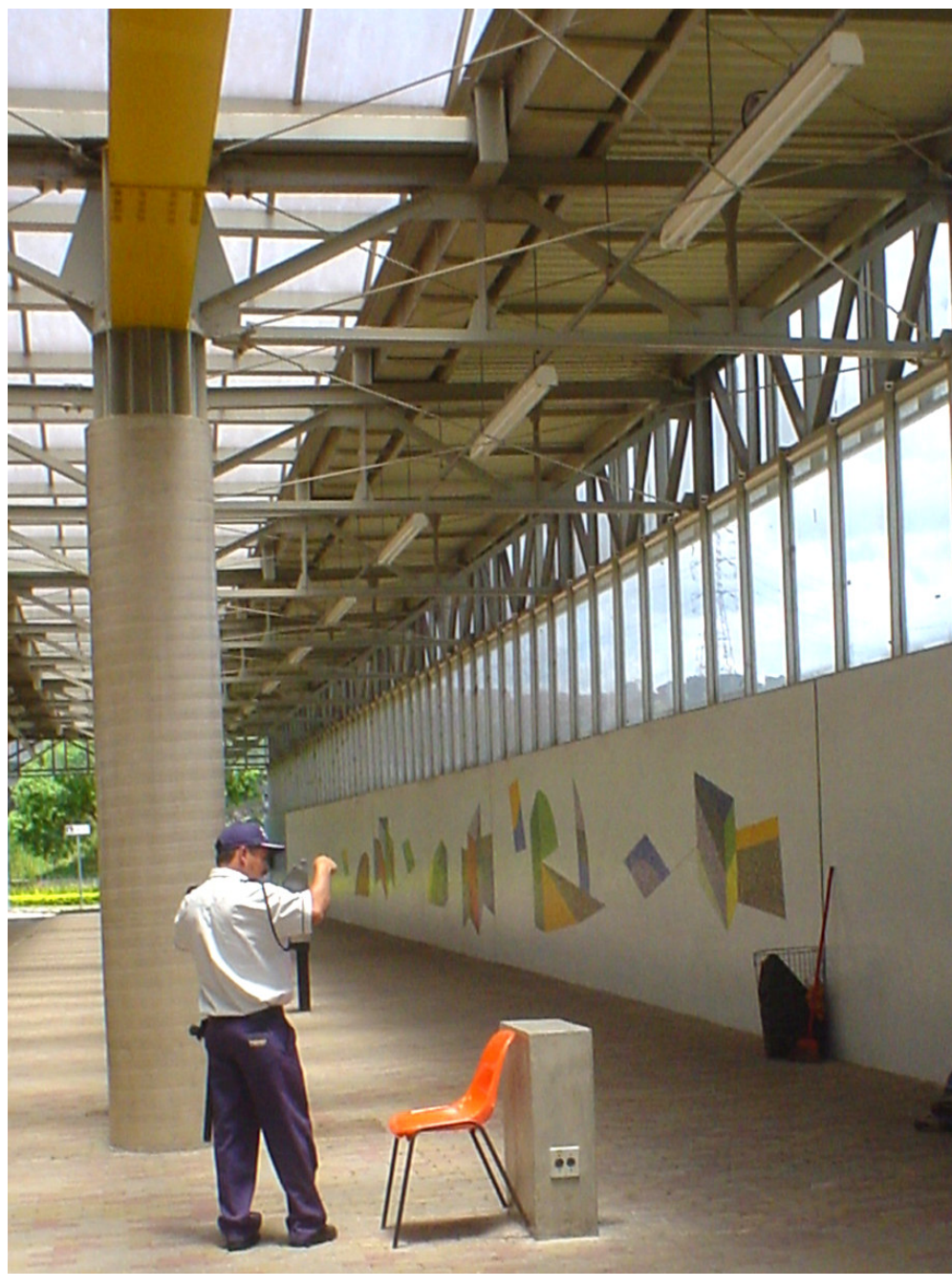

Figura 136 - Terminal de ônibus da Estação Santo Amaro. (Foto da autora)
Na ocasião da visita ao terminal de ônibus integrado à estação ferroviária Santo Amaro, o espaço encontrado pela autora ainda era o de um terminal de ônibus a ser inaugurado, sem ônibus e sem passageiros. O espaço do terminal, fechado por uma vedação transparente sustentada por uma estrutura metálica, permite uma boa iluminação natural e a sensação de leveza e amplitude.

O mosaico de Odiléa Toscano também agrega os elementos de luminosidade, leveza e amplitude. A luminosidade está no próprio material (algumas pastilhas mais brilhantes foram fabricadas especialmente para este mural) e no fundo branco, que, além disso, contribui para a amplitude. A leveza está evidente pelo fato de, apesar de o mosaico estar no nível do chão, as figuras, linhas, superfícies e volumes, estarem acima dele, como se flutuassem. Deste modo, mesmo os volumes mais massiços ganham leveza. Também há uma percepção de tridimensionalidade dos volumes que varia de acordo com a posição do observador. Essa diferença é percebida durante o caminhar como uma transformação das formas. 


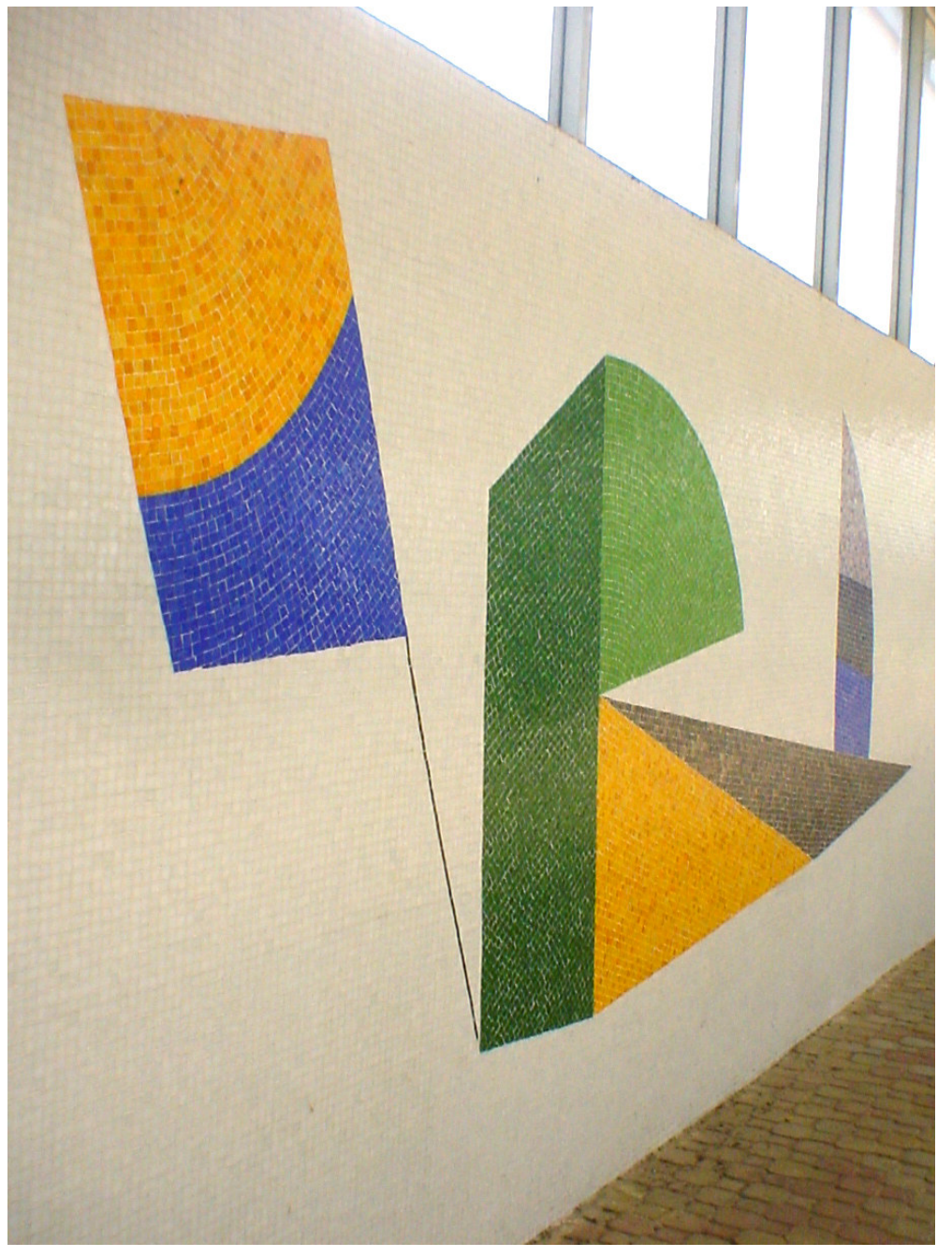

Figura 137 - Detalhe do mosaico onde é possível visualizar os elementos superfície, linha e volume. (Foto da autora)
A artista acompanhou de perto a execução do mosaico para garantir que as cores, os traços e a disposição das pastilhas estivessem de acordo com seu projeto, como, por exemplo, as linhas finas que foram feitas com pastilhas cortadas ao meio. Ela escreveu sobre este trabalho: ${ }^{44}$

Foram trabalhadas séries de formas, com ênfase para a linha, as superfícies e os volumes. As seqüências estabelecem um diálogo entre esses três elementos geométricos. A variedade de cores disponíveis permitiu a necessária vibração que requer o desenho, que se desenvolve sobre o branco intenso, de textura rica, conferida pelo próprio material. $A$ pastilha prateada foi fabricada especialmente para este projeto, preenchendo plenamente as intenções almejadas.

Reafirmando o que se disse acima, a relação figura/fundo fica bastante enfatizada, tanto pelo desenho como pela cor, traduzida pelo material e pelo suporte branco.

\footnotetext{
${ }^{44} \mathrm{Em}$ carta enviada à autora no dia $1^{\circ}$ de fevereiro de 2007.
} 
- Autora: Odiléa Toscano (1934-).

- Arquiteto: João Walter Toscano.

- Implantação: Parede dentro do terminal.

- Uso do edifício: terminal de ônibus urbano.

- Data: 2002.

- Tema: abstrato geométrico.

- Dimensões: 2,4x32m.

- Assinatura: canto inferior esquerdo.

- Transcrição da assinatura: ODILÉA 2002.

- Execução: Vidrotil.

- Data de avaliação: out/2006.

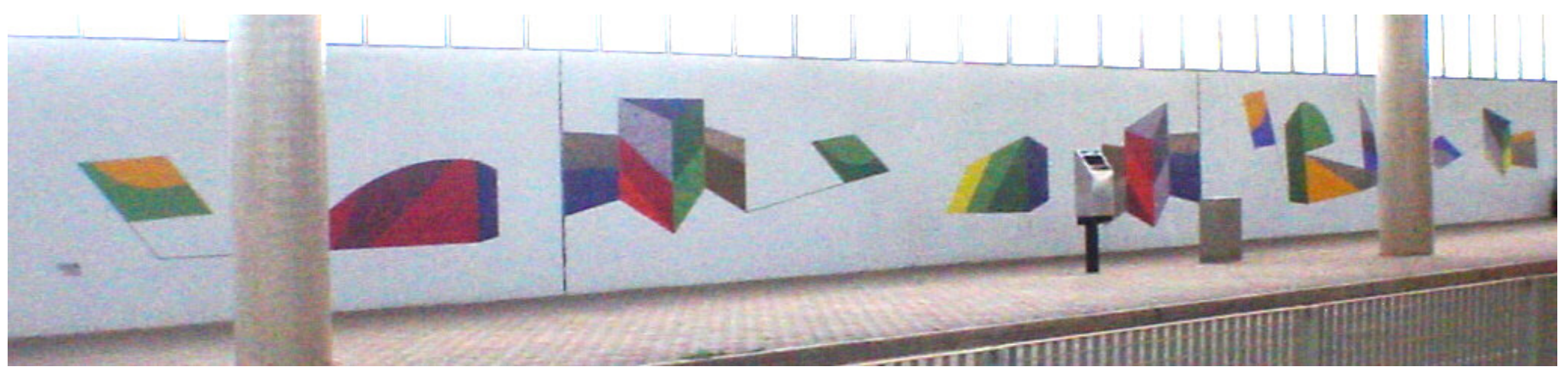

Figura 138 - Mosaico de Odiléa Toscano no terminal de ônibus de Santo Amaro. (Foto da autora) 


\subsection{Centro Empresarial Itaúsa 2} Vik Muniz

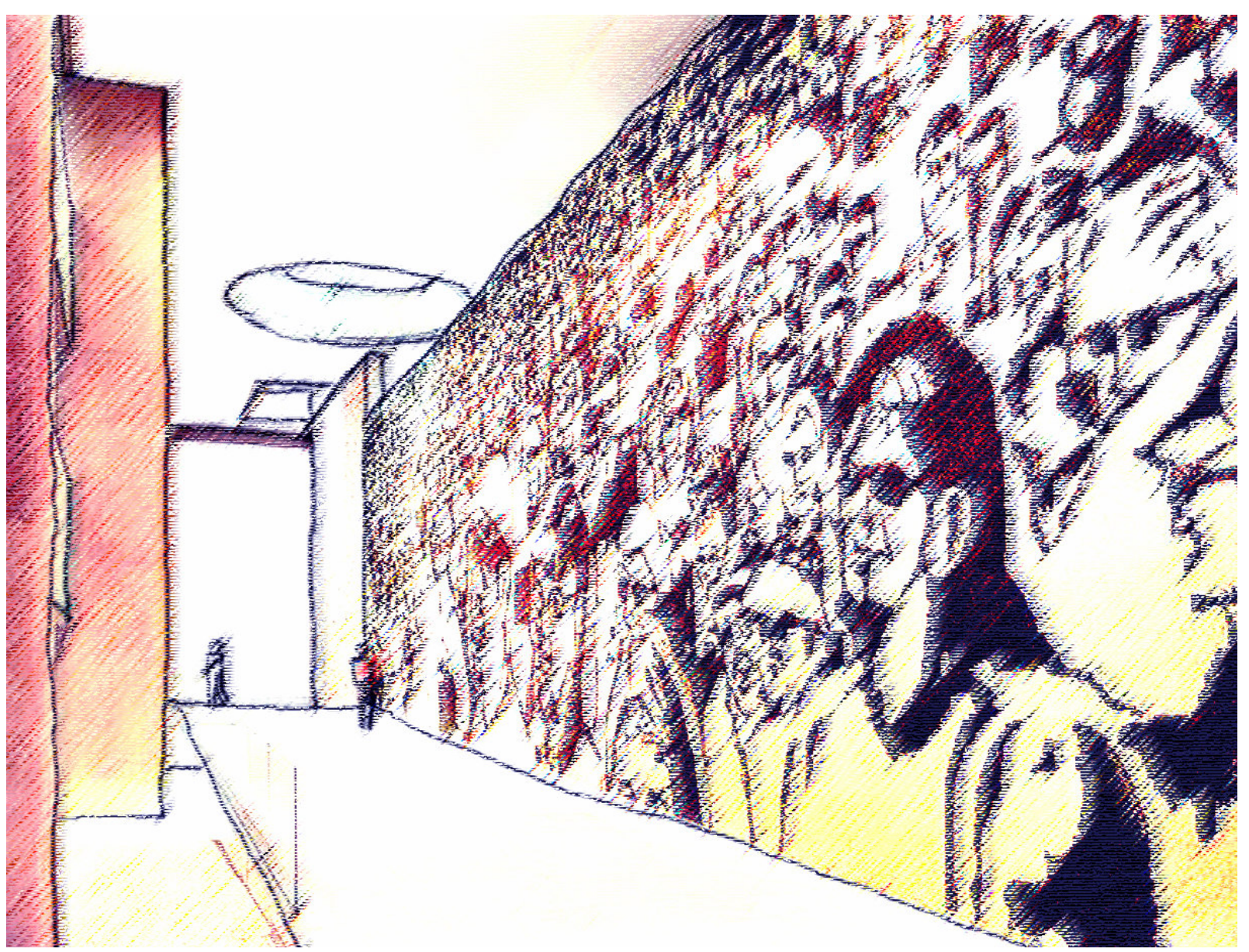

Figura 139 - Ilustração da passagem subterrânea no Centro Empresarial Itaúsa. (llustração da autora) 


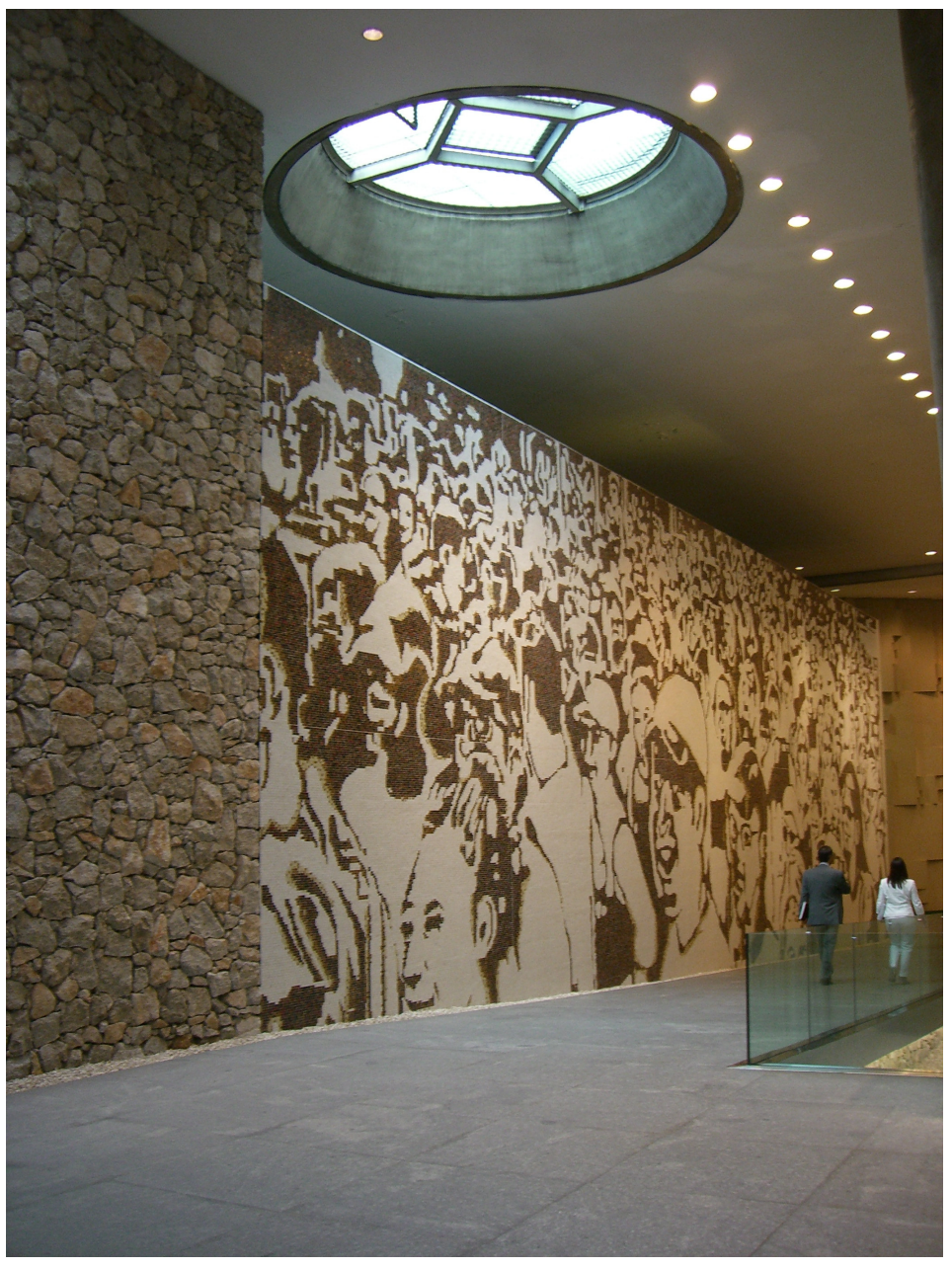

Figura 140 - Mosaico de Vik Muniz visto da extremidade superior da rampa. (Foto da autora)
O mosaico de Vik Muniz encontra-se em uma passagem subterrânea entre dois edifícios do Centro Empresarial Itaúsa. Está em uma parede de $24 \mathrm{~m}$ de comprimento por $7,9 \mathrm{~m}$ de altura junto a uma rampa. Para quem está na rampa, não é possível observar o mosaico a uma distância maior do que $4 \mathrm{~m}$. Só é possível observá-lo a uma distância um pouco maior a partir de uma de suas extremidades.

Uma fotografia de uma multidão feita de chocolate foi reproduzida em mosaico com bastante fidelidade. As pastilhas utilizadas são de cores que vão do bege-claro ao marrom-escuro, passando por tons de caramelo e alguns toques de preto e vermelho e o fundo branco.

A colocação das pastilhas seguiu o sistema de obra tesselada com as pastilhas alinhadas perfeitamente tanto na vertical quanto na horizontal. Um dos motivos desta opção foi para viabilizar a execução do mosaico em menos tempo, e esta opção também estava de acordo com a idéia do artista de fazer imagens do modo mais grosso possível para que as 


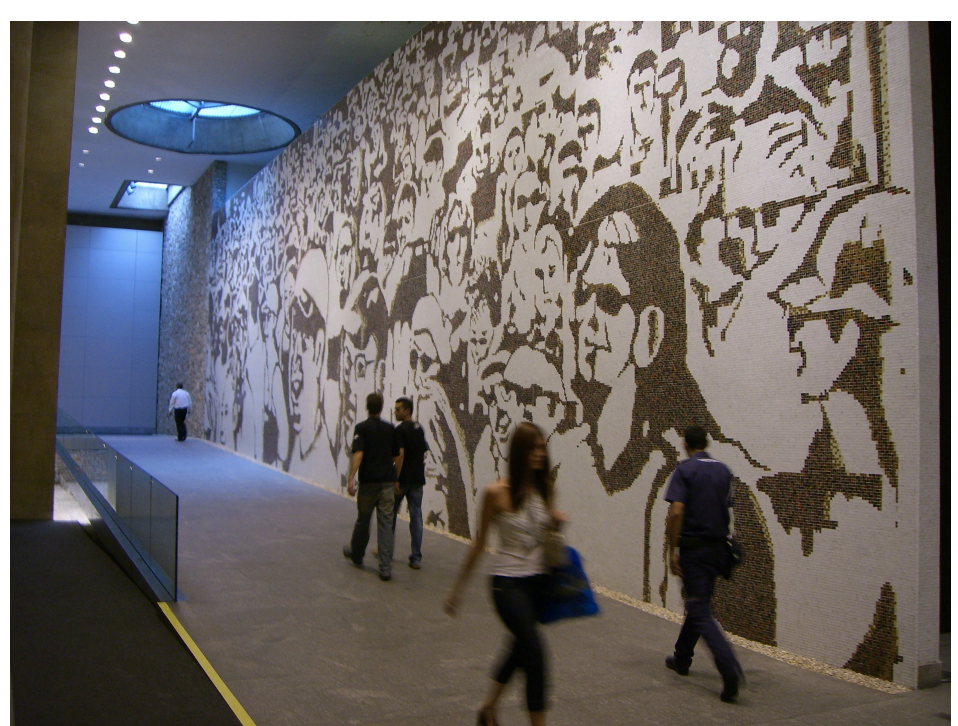

Figura 141 - Mosaico visto da extremidade inferior da rampa. (Foto da autora) pessoas se percam na trama. $\mathrm{O}$ artista também apontou que esse mosaico ganhou um efeito de pixels. ${ }^{45}$

O artista descreve esta obra como uma equação entre o figurativo e o abstrato; o figurativo são os rostos que se percebem e o abstrato é a multidão fundida ao fundo que aparece como manchas. Devido ao pequeno espaço que não permite a observação do mosaico à distância, e ao fato de estar em uma área de circulação, mesmo os rostos mais bem-definidos chegam a não serem vistos pelas pessoas que passam por ali diariamente.

\section{A arquiteta Ane Leite que trabalha no local declarou} não ter percebido, de imediato, um rosto pela primeira vez, mas, depois, ao logo dos dias, foi percebendo outros rostos. A obra é descoberta aos poucos, a cada passagem rápida. Nessas descobertas está a dimensão cinética da obra.

\footnotetext{
${ }^{45}$ Vic Muniz falou sobre sua obra no documentário llusões fotográficas de Vik Muniz. Dir. Cacá Vicalvi e Zezo Cintra. Documenta Video Brasil. São Paulo
} 


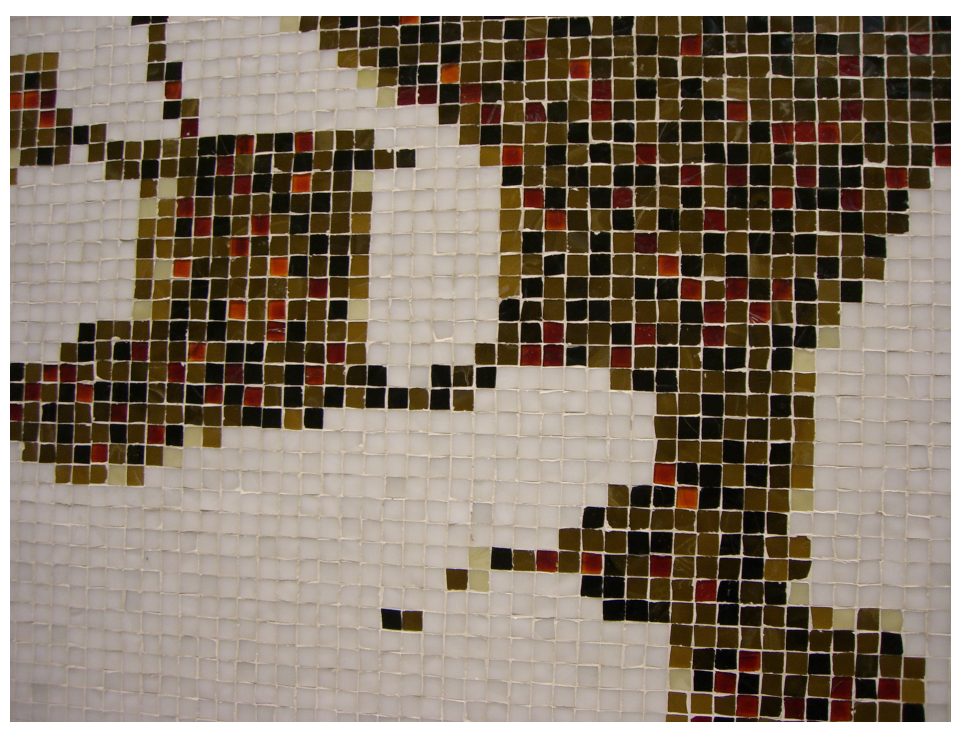

Figura 142 - Detalhe do mosaico. Visto de perto não se pode identificar o desenho. (Foto da autora)

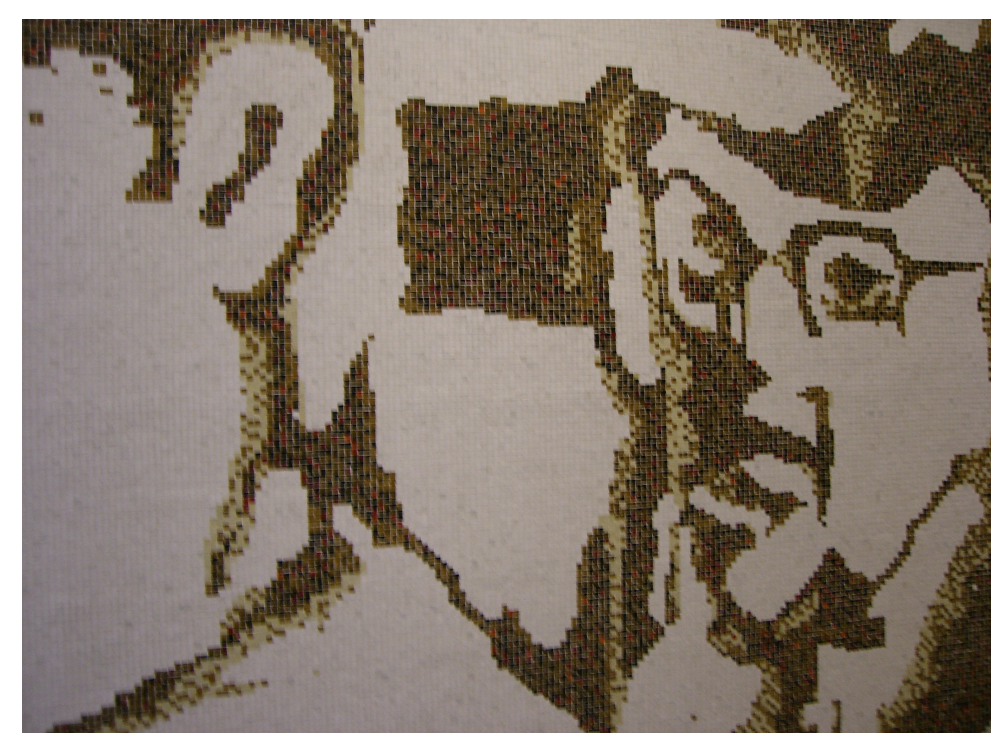

Figura 143 - Detalhe do mosaico. A uma distância um pouco maior é possível identificar um rosto. (Foto da autora) 
- Autor: Vik Muniz (1961-).

- Título: Multidão.

- Arquitetos: Superintendência de Arquitetura do Grupo Itaú em parceria com Aflalo \& Gasperini.

- Endereço: Praça Alfredo Egydio de Souza Aranha, 100, São Paulo, SP.

- Implantação: parede junto à rampa no subsolo.

- Uso do edifício: escritórios.

- Data: 2002/2003.

- Tema: multidão.

- Dimensões: 7,9 x $24 \mathrm{~m}$.

- Assinatura: não é assinado.

- Execução: Vidrotil.

- Data da avaliação: dez/2006.

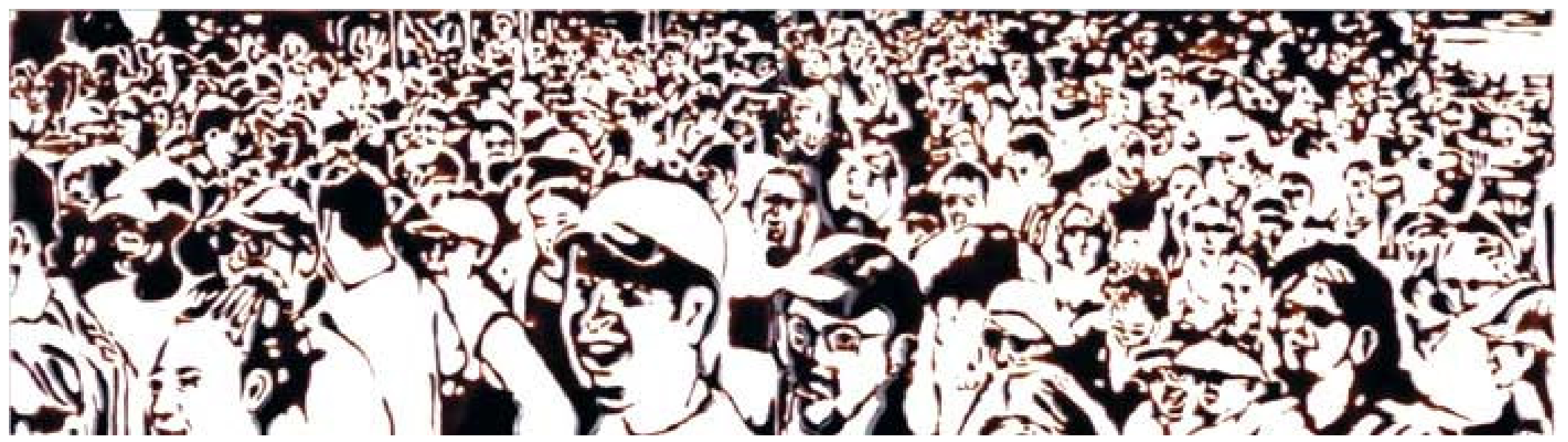

Figura 144 - Obra de Vik Muniz em chocolate que deu origem ao mosaico. (Fonte: www.arcoweb.com.br/empresas/vidrotil/boletim6.asp, foto de divulgação) 


\subsection{Edifício Exclusive} Claudio Tozzi

Figura 145 - Edifício Exclusive na

Avenida Angélica.

(ilustração da

autora)

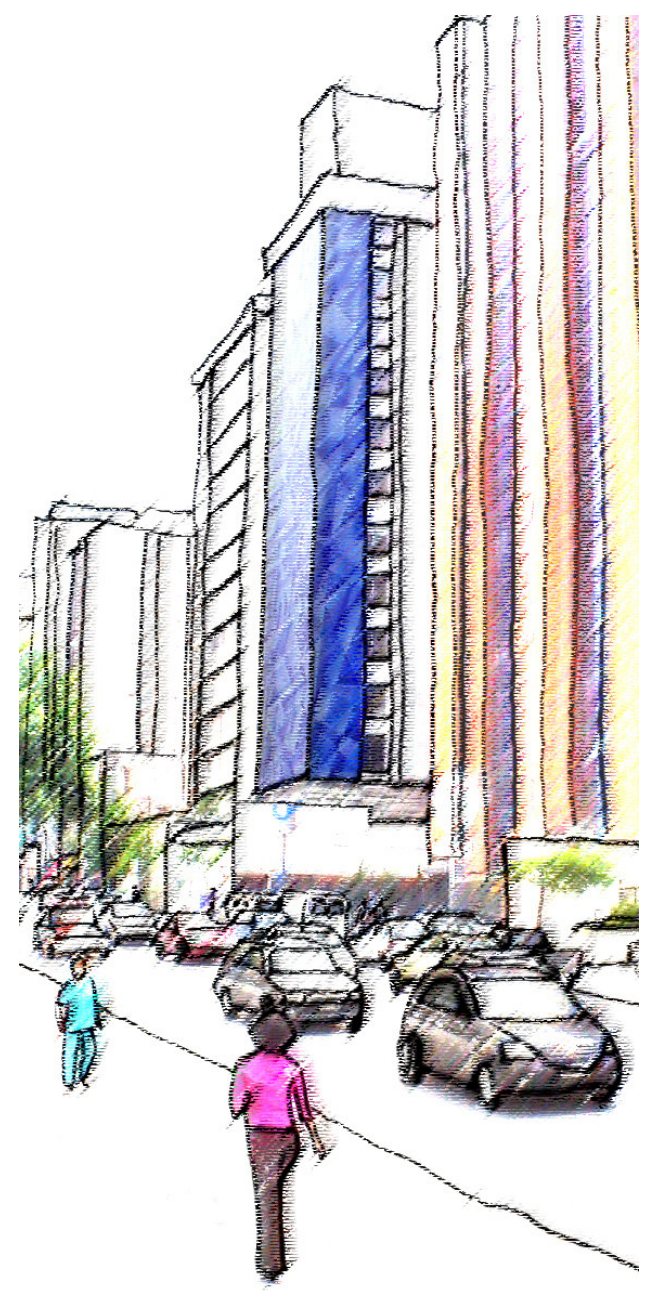




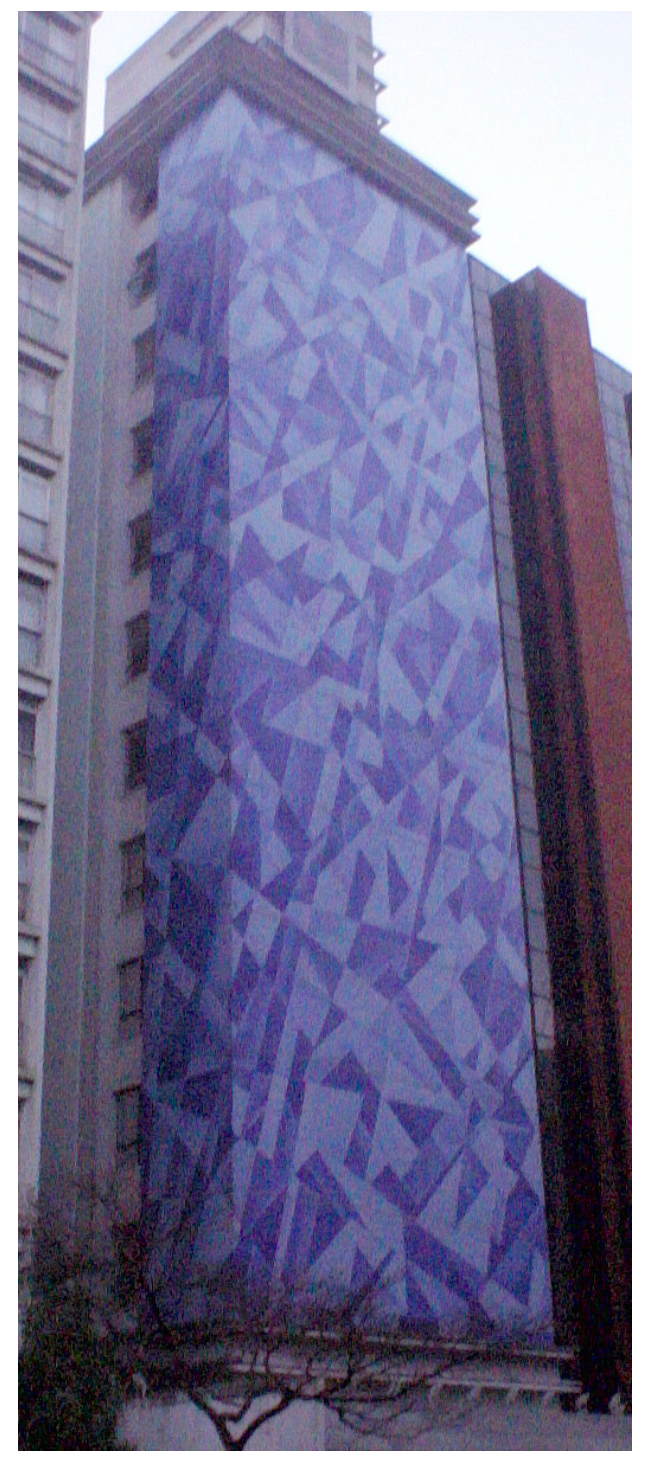

O mosaico do Edifício Exclusive na Avenida Angélica foi escolhido por meio de um concurso realizado em $2002 \mathrm{e}$ teve como jurados Enock Sacramento, Fábio Magalhães e Jacob Klintowitz.

Sobre esse mosaico, Claudio Tozzi disse em entrevista a Fábio Magalhães: ${ }^{46}$

O painel da Av. Angélica no Edifício Exclusive, perto da Rua Goiás foi pensado em função de criar um invólucro para a fachada e parte das laterais do prédio. A Solução do projeto foi dada em função de integrar a fachada do prédio ao referencial cromático já existente em seu entorno. Seria a criação de um marco, de um edifício-signo, que ao se integrar no espaço já existente daria uma identidade visual específica para o edifício. Escolhi a cor azul, por ser a mais adequada a criar um diálogo com o espaço existente. O projeto foi o vencedor de um concurso onde participaram cerca

Figura 146 -

Mosaico de

Claudio Tozzi no

Edifício Exclusive. (Foto da autora) de 500 projetos. Trabalhei com pastilhas de vidro

${ }^{46}$ MAGALHÃES, Fábio, Claudio Tozzi. São Paulo: Ed. Lazuli e 
fundido, em 16 tonalidades de azul. A mistura das

tonalidades possibilitou a criação de efeitos visuais $e$ matizes que dão uma sutil vibração cromática ao conjunto.

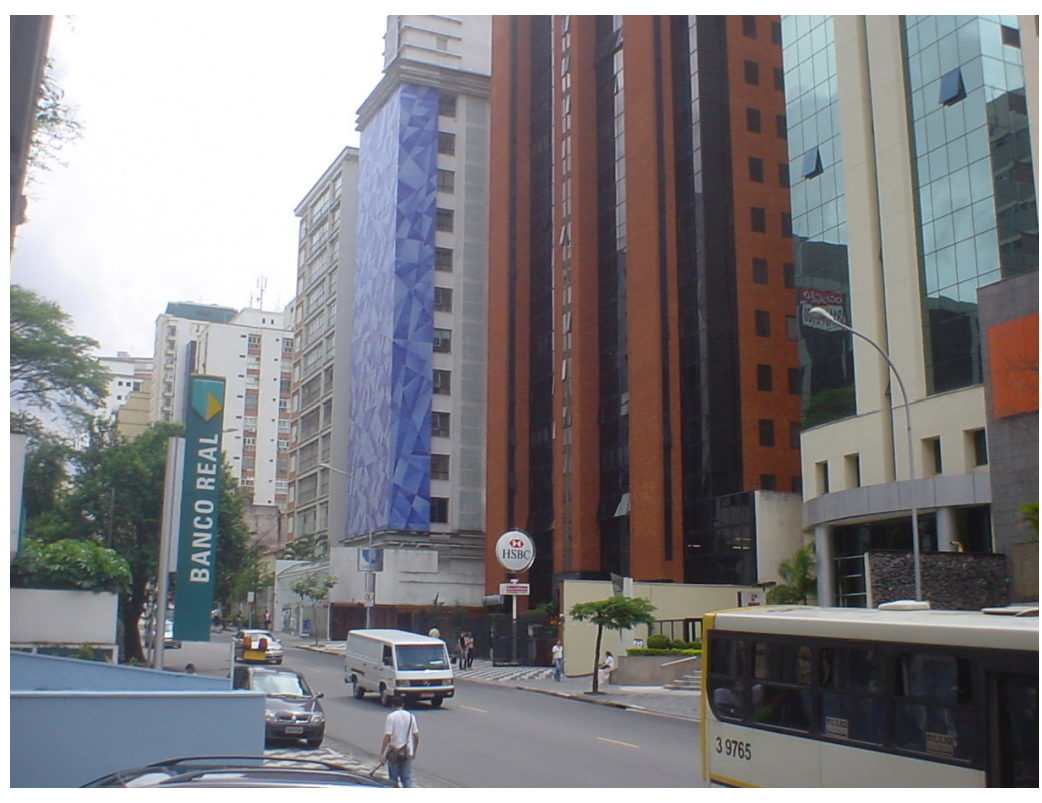

Figura 147 - Avenida Angélica. (Foto da autora)

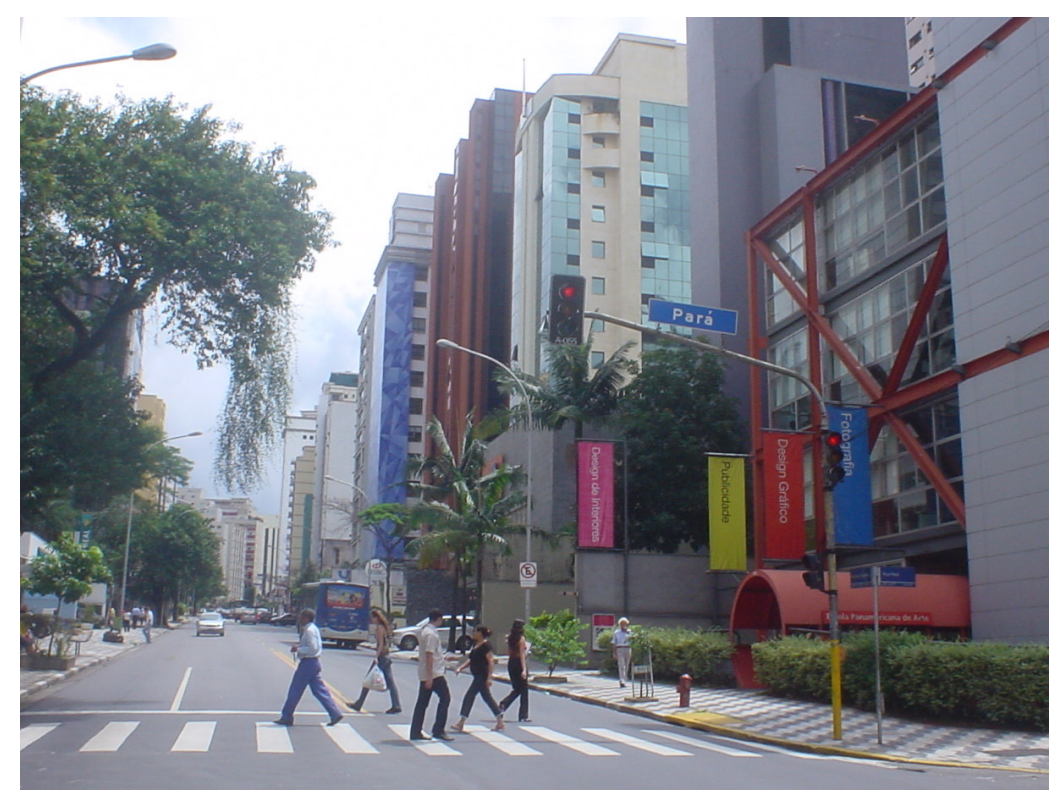

Figura 148 - Avenida Angélica. (Foto da autora) 


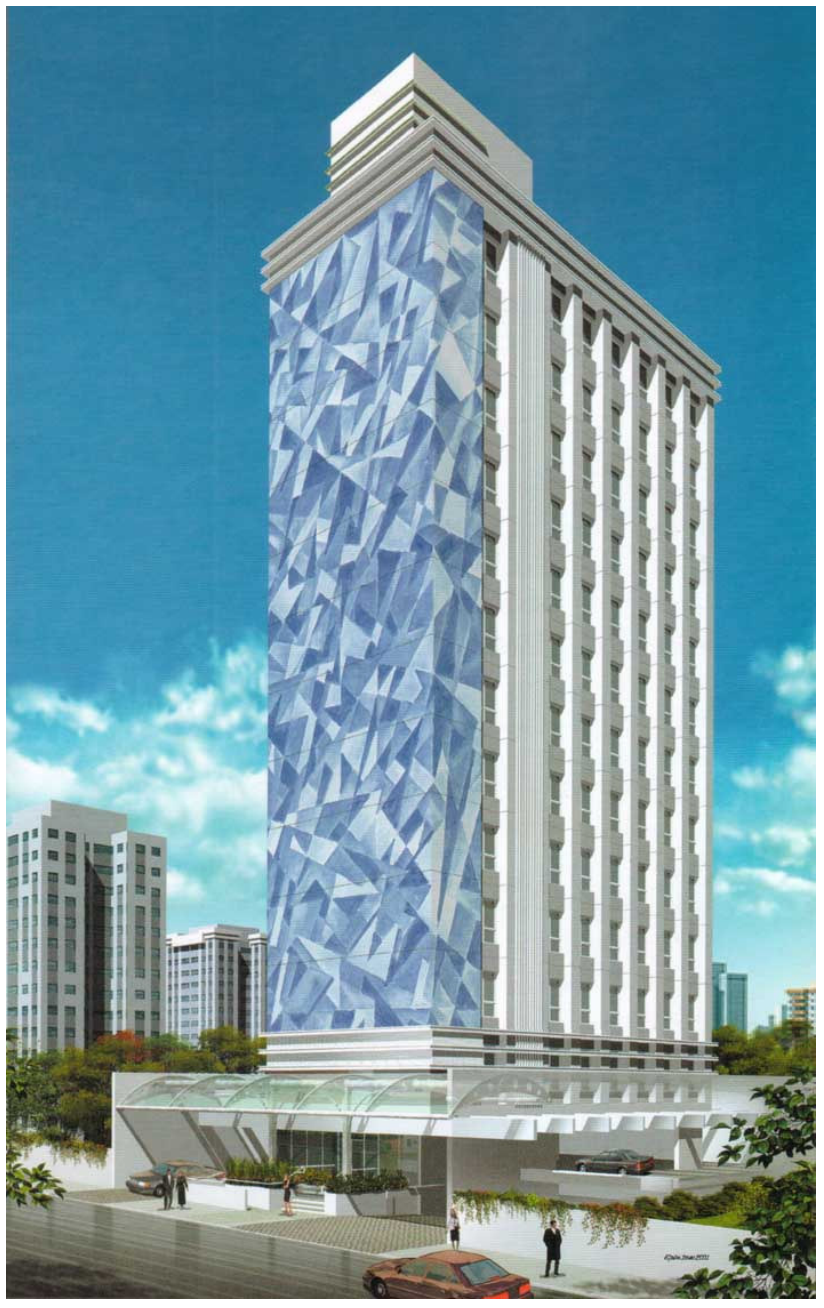

Figura 149 - Perspectiva ilustrando projeto do mural do Ed. Exclusive.
- Autor: Claudio Tozzi

- Endereço: Av. Angélica, 2016, São Paulo, SP.

- Implantação: toda a fachada acima do andar térreo e parte das laterais do edifício.

- Uso do edifício: comercial, escritórios.

- Data: 2003.

- Tema: abstrato.

- Dimensões: $600 \mathrm{~m}^{2}$.

- Assinatura: canto inferior direito.

- Transcrição da assinatura: Clau Tozzi.

- Execução: Mosaico Objeto de Arte e Oficina do Mosaico.

- Data da avaliação: jun/2006. 


\subsection{Fórum Trabalhista} Claudio Tozzi

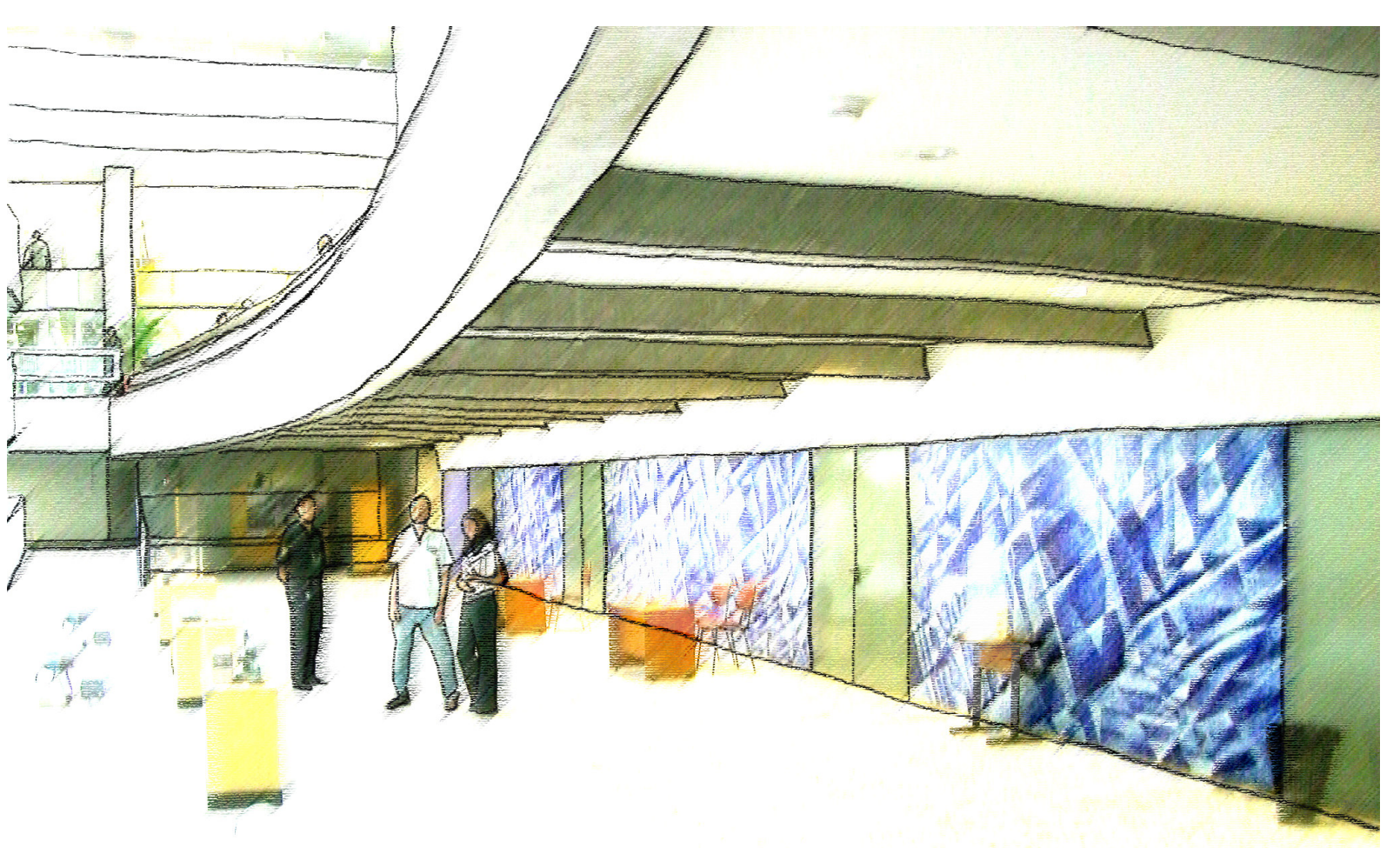

Figura 150 - Entrada do auditório do Fórum Trabalhista. (Ilustração da autora) 


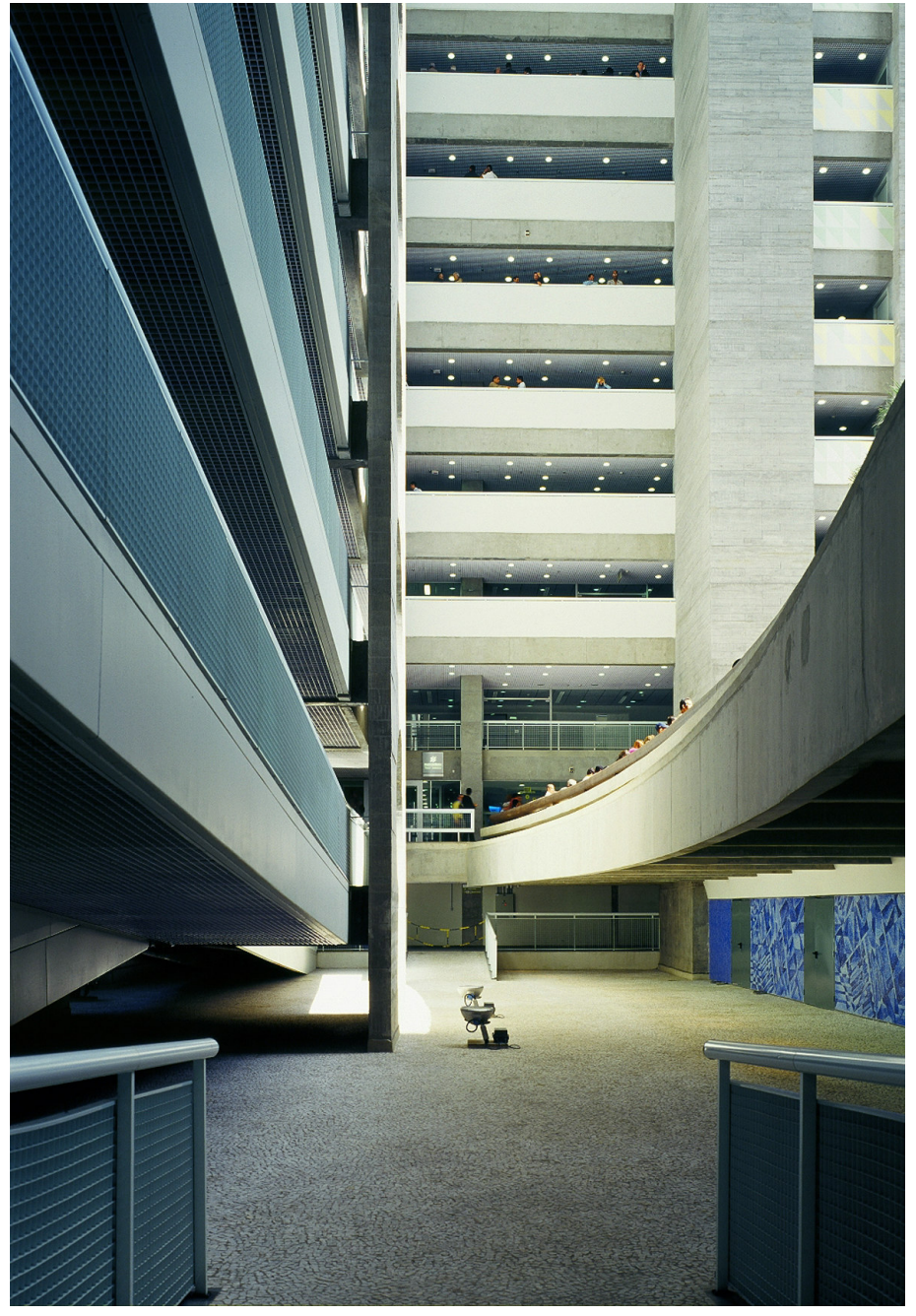

Figura 151 - Interior do Fórum Trabalhista. (Foto de Cristiano Mascaro, arquivo de Claudio Tozzi)
O Fórum Trabalhista Ruy Barbosa ocupa um edifício de grandes proporções, projetado pelo arquiteto Décio Tozzi. Devido a isso, um mosaico com o tamanho do que foi executado no local só teria um peso se fosse colocado em um ponto onde não fosse desfavorecido pela escala.

Os três painéis em mosaico de Claudio Tozzi encontram-se na entrada do auditório, separados pelas portas, no subsolo, onde se encerram as rampas. É uma área com o pé direito baixo e a disposição dos painéis se estende por todo o plano horizontal. As rampas são um elemento marcante que percorre toda a extensão vertical do edifício.

O tema parafusos pareceu bastante adequado ao local por estar ligado à idéia de trabalho. Assim como Colcha de Retalhos e os mosaicos do Novotel, este também foi executado com pastilhas cortadas em $1 \times 1 \mathrm{~cm}$, uma boa solução para mosaicos que também podem ser vistos de perto. 


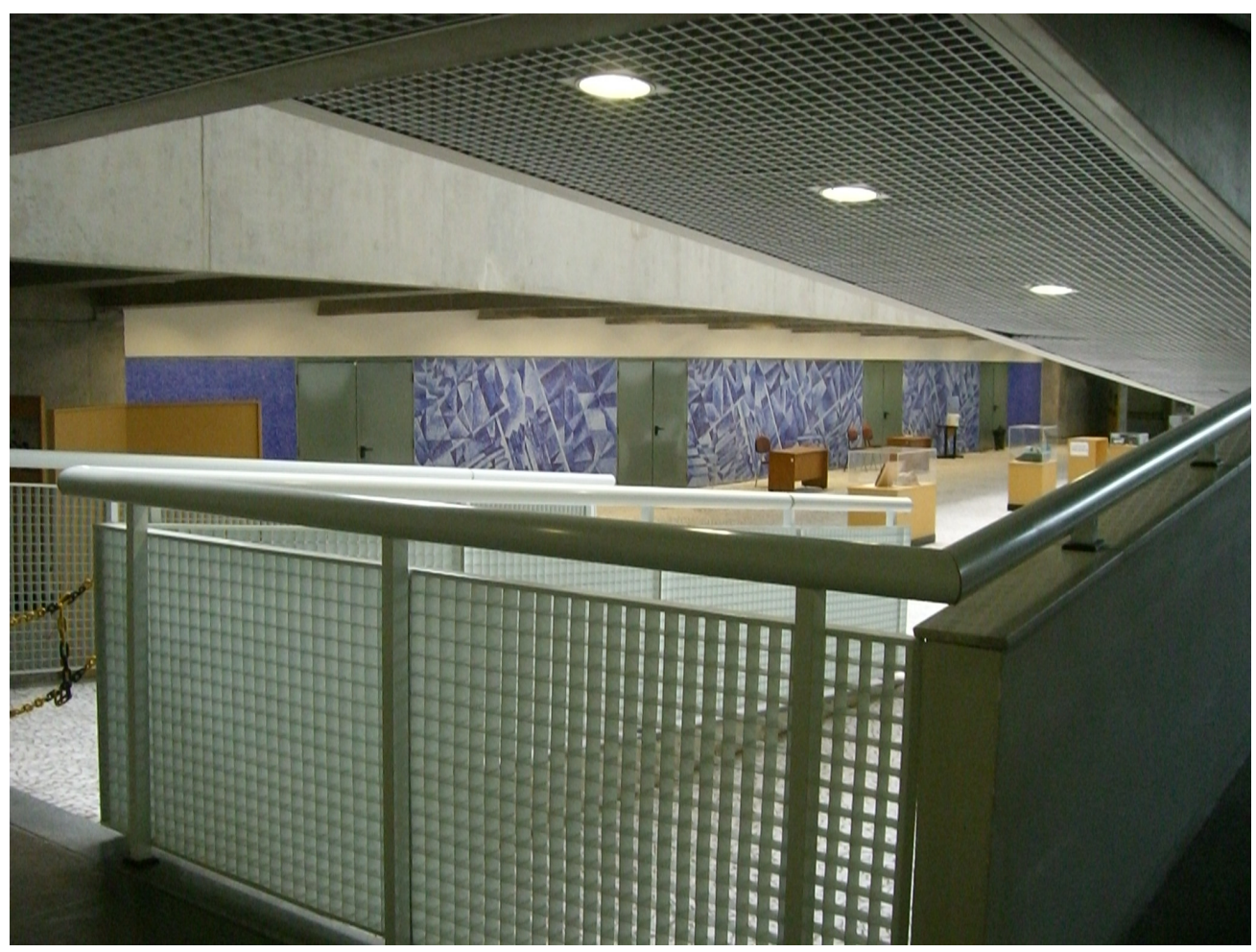

Figura 152 - Composição de mosaico vista por entre as rampas. (Foto da autora)
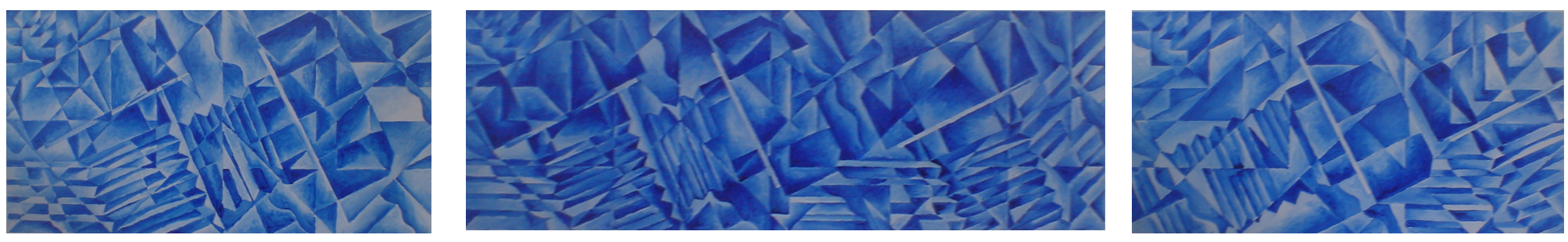

Figura 153 - Projeto dos painéis do Fórum Trabalhista. (Fonte: arquivo do Claudio Tozzi) 

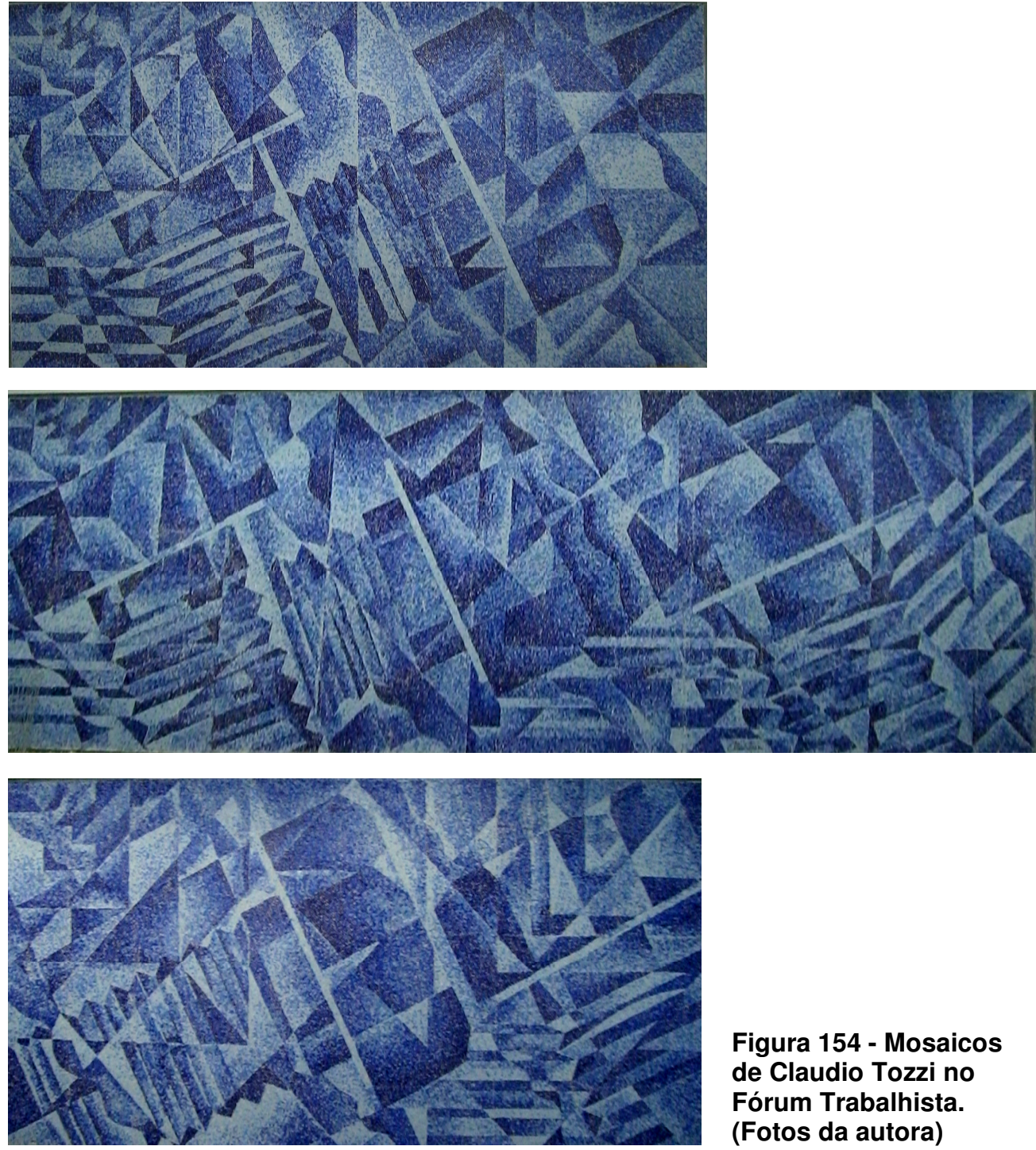

Figura 154 - Mosaicos de Claudio Tozzi no

Fórum Trabalhista. (Fotos da autora)
- Autor: Claudio Tozzi(1944-).

- Arquiteto: Décio Tozzi

- Endereço: Av. Marquês de São Vicente, 235, São Paulo, SP.

- Implantação: no subsolo, na entrada do auditório.

- Uso do edifício: fórum.

- Data: 2004.

- Tema: parafusos.

- Dimensões: respectivamente, $1200 x \mathrm{xm}$, 1900xm e 1200xm.

- Assinatura: canto inferior direito.

- Transcrição da assinatura: Clau Tozzi.

- Execução: Mosaico Objeto de Arte.

- Data da avaliação: jan/2007. 


\title{
Considerações finais
}

\author{
Nós adoramos o caos porque \\ amamos produzir a ordem. \\ - M. C. Escher
}

O capítulo 1, Ver mosaicos, serviu como um primeiro passo para o leitor se familiarizar com o tema mosaicos. Nele refletiu-se mais a fundo sobre o que é um mosaico e os mais diferentes tipos de aplicação. Viu-se que existem mais mosaicos do que normalmente se imagina e que existe uma tendência natural das pessoas de ordenar pequenas partes de tudo (pedras, pastilhas, idéias, pixels, retalhos etc).

Embora esta dissertação trate mais profundamente dos mosaicos no espaço da arquitetura e da cidade, os exemplos de aplicação de mosaicos apresentados no capítulo 1 vão além desses espaços por mostrar também exemplos de 
mosaicos que podem ser encontrados em outros lugares, desde o vestuário até o visor de um celular.

Viu-se que o conceito de mosaico pode ser muito amplo, por isso, foram excluídos exemplos de mosaicos que não são criados pelo homem, como os que são criados pela natureza, que poderiam ser representados pela espiga de milho e pelo casco de tartaruga, pois, para serem criados, não solicitaram esforço mental de nenhuma pessoa.

Fazer mosaicos é uma ação natural do ser humano. Por alguma obra do acaso, exatamente no dia em que a autora estava começando a escrever estas considerações finais, havia deixado algumas pastilhas de vidro despejadas sobre a mesa. Seu avô de 86 anos, assim que as viu, sentouse e, com toda disposição e paciência, manipulou as pastilhas formando palavras. Ele estava criando uma composição ordenada e, ao mesmo tempo, comprovando, diante dos olhos da autora, esta afirmação.

A experiência que a autora teve no desenvolvimento deste trabalho foi de grande valia para entender o mosaico 
fundamentalmente como trabalho mental. Isso já é sabido, mas as experiências de exercitar sua visão procurando perceber as diversas formas de feitura e aplicação de mosaicos, de fazer o seu próprio painel e de acompanhar a execução de um mural, levaram-na a absorver essa noção pela vivência.

Apesar de já ter tido uma experiência anterior como muralista, tendo projetado um mosaico de grandes dimensões para o espaço público, ainda the faltava uma experiência como mosaicista, trabalhando na parte da sua execução. A experiência de fazer um painel em mosaico para esta dissertação foi fundamental.

Fazer o mosaico Laços, documentado no capítulo 2, foi como fazer uma escultura e uma pintura ao mesmo tempo. A pintura por causa da composição cromática e a escultura pelo fato de o senso do tato estar muito presente na descoberta de sutilezas como as diferentes durezas de pastilhas. Ao cortálas, percebe-se claramente que mesmo que as peças tenham apenas $3 \mathrm{~mm}$ de espessura está-se manipulando objetos tridimensionais. 
A entrevista de Sérgio Secches foi praticamente um mergulho na emoção, na paixão do artista. Conduzida pela autora que elaborou as perguntas mais relacionadas ao trabalho, contou também com a participação da jornalista Montserrat Bevilaqua que, com sua experiência em entrevistas, foi decisiva para deixar o entrevistado à vontade para falar abertamente, permitindo o registro de sua visão da arte, da interação do mosaico com o espaço e as dificuldades e alegrias que encontrou e encontra em sua trajetória de mosaicista.

Já a entrevista de Claudio Tozzi foi mais pelo lado racional, pois o artista expressou-se com muita clareza e objetividade, condizentes com sua atribuição como professor universitário.

Com as entrevistas prontas, houve a constatação de que uma está complementando a outra. O ponto em comum salientado nas duas entrevistas, e que vale ressaltar aqui novamente, foi que pensar o projeto do mosaico para o seu espaço é fundamental. 
Sobre os mosaicos no espaço da arquitetura e da cidade, apresentados no capítulo 3, aparentemente os artistas de 50 e 60, trabalhando junto aos arquitetos, tinham uma preocupação maior com a interação do mural com a arquitetura, enquanto os da virada do século, ainda que não abandonando esse enfoque, parecem estar concentrando-se mais no fazer do mosaico e em sua expressão individual.

Nesta virada de século, também se constata que os mosaicos não são, necessariamente, projetados com uma intenção de que permaneçam presos aos locais onde estão instalados. Muitos trabalhos estão sendo executados em painéis que podem, eventualmente, ser removidos, como o caso dos painéis da Tomie Ohtake, no metrô, e de Herton Roitman, na Porto Seguro, além de trabalhos mais antigos que são cuidadosamente removidos de superfícies que, supunha-se, seriam definitivas, como o caso do mosaico de Portinari retirado do Hotel Comodoro.

Os artistas dos anos 50 e 60 exploravam mais temas relacionados com a função dos edifícios do que os artistas da atualidade, predominando temas figurativos e didáticos. Os 
arquitetos modernos acreditavam que a funcionalidade era algo de extrema importância, isso indica que muitos murais modernos, como os de Di Cavalcanti, tinham a função de comunicar o que acontecia no edifício.

Foi observado que nos mosaicos dos anos 80,90 e século XXI a mistura de pastilhas com diferentes cores é mais explorada, conferindo a esses mosaicos um efeito mais vibrante do que dos mosaicos de 50 e 60 . Também pode ser observado que a disposição das pastilhas dos mosaicos recentes está mais solta do que as dos mosaicos anteriores. Aparenta que a intenção, ao montar um mosaico, nas décadas de 50 e 60, era mais de preencher as cores reproduzindo o desenho do artista do que explorar as possibilidades que a técnica oferecia para expressar como mosaico e não apenas como reprodução de figura.

Ao longo do levantamento, ficou cada vez mais evidente a importância da iluminação no ambiente onde está instalado o mosaico em pastilha de vidro. Por se tratar de um material bastante brilhante, quando a iluminação não é difusa, alguns pontos do mosaico refletem os pontos de luz, 
impedindo que o mosaico seja visto por inteiro. Os ambientes externos e internos com iluminação natural, em geral, são os mais favoráveis.

Reunindo tudo o que está apresentado nesta dissertação, percebe-se que o mosaico é extremamente flexível, permitindo as mais diversas aplicações, pelas mais diferentes pessoas, nos mais diferentes lugares, nas mais diferentes épocas.

Depois de mergulhar no tema ao longo deste trabalho, a sensação é de que se vê mosaicos em tudo, ou que tudo é mosaico. E a pergunta que fica é: Será que o espaço quadridimensional de Minkowski é, na verdade, um imensurável mosaico de mosaicos? 


\section{Bibliografia}

ADAMS, William Howard. Roberto Burle Marx: The unnatural art of the garden. New York: The Museum of Modern Art, 1991.

AMARAL, Araci Abreu. Arte e meio artístico (1961-1981): entre a feijoada e o x-burguer. São Paulo: Nobel, 1983.

ANDRADE, Carlos Drummond de. Antologia poética. Rio de Janeiro: Record, 1999.

ARGAN, Giulio Carlo. Arte moderna: do ilusionismo aos movimentos contemporâneos. São Paulo: Companhia das Letras, 1996.

ARTE NO METRÔ. São Paulo: Companhia do Metropolitano de São Paulo, 1994.

BENEVENTO, Marcia Maria. Espaço de relacionamento - a presença do lúdico nas atividades de recreação. São Paulo: dissertação de mestrado. Faculdade de Arquitetura e Urbanismo da Universidade de São Paulo, 1999.

BONSIEPE, Gui. Design: do material ao digital. Florianópolis: FIESC/IEL, 1997. 
BRANDÃO, Junito de Sousa. Dicionário mítico-etimológico da mitologia grega. Petrópolis: Vozes, 1991.

CHARBONNEAUX, Jean; MARTIN, Roland; VILLARD,

François. Grèce hellénistique: 330-50 av. J.-C. Paris: Éditions

Gallimard, 1987.

CAMPOS, Maria Cristina André. Memória urbana: mural moderno em São Paulo. São Paulo: dissertação de mestrado. Faculdade de Arquitetura e Urbanismo da Universidade de São Paulo, 2001.

CARROLL, Lewis. Alice no País das Maravilhas, Lisboa:

Publicações Dom Quixote, 2000.

CHAVARRIA, Joaquim. O Mosaico. Lisboa: Editorial Estampa, 1998.

COELHO, Isabel Ruas Pereira. Painéis em mosaico na arquitetura moderna paulista. - 1945-1964 São Paulo: dissertação de mestrado. Faculdade de Arquitetura e Urbanismo da Universidade de São Paulo, 2000.

COLTON, Virginia (ed.). Complete guide to needlework.

Estados Unidos da América: The Readr's Digest Associaion, 1979.

CULLEN, Gordon. Paisagem Urbana. Lisboa: Edições 70, 1996. 
FERREIRA, Aurélio Buarque de Holanda. Novo Aurélio Século XXI: o dicionário da língua portuguesa. Rio de Janeiro: Nova fronteira, 1999.

FERRIS, Timothy. The whole shebang. New York: Simon \& Schuster, 1997.

HETHERINGTON, P. B. Mosaics. Verona: Paul Hamly, 1967. GRABAR, André. La peinture byzantine. Genebra: Editions d'Art Albert Skira, 1953.

HUNDERTWASSER, Friedensreich. For a more human architecture in harmony with nature - Hundertwasser architecture. Alemanha: Taschen, 1997.

JUNG, Carl G. O homem e seus símbolos. Rio de Janeiro: Editora Nova Fronteira, 1964. INVENTÁRIO DE ARQUITETURA MODERNA DO VALE DO PARAÍBA - VOLUME I. Vale do Paraíba: DOCOMOMO Brasil - Núcleo Regional Vale do Paraíba. 1997.

KIYOMURA, Leila; GIOVANNETTI, Bruno (Org.). Claudio Tozzi. São Paulo: Editora da Universidade de São Paulo e Imprensa Oficial do Estado, 2005.

KLINTOWITZ, Jacob. Claudio Tozzi: o universo construindo a imagem. Brasil: Valoart, 1989. 
LOCHER, J.L., Escher - the complete graphic work. Holanda: Thomes and Hudson, 1992.

LOURENÇO, Maria Cecília França. Operários da Modernidade. São Paulo: Hucitec/Edusp, 1995.

LYNCH, Kevin. A imagem da cidade. Lisboa: Edições 70, 1960.

MACHADO, José Pedro. Dicionário Etimológico da língua portuguesa. Lisboa, Editorial Confluência, 1959.

MAGALHÃES, Fábio, Claudio Tozzi. São Paulo: Ed. Lazuli e Companhia Editora Nacional, 2007. (Coleção Arte de Bolso) (no prelo).

MARCONDES, Luiz Fernando. Dicionário de termos artísticos. Rio de Janeiro: Edições Pinakotheke, 1998.

MORAIS, Frederico. Panorama das Artes Plásticas, séculos XIX e XX. São Paulo: Instituto Cultural Itaú, 1991.

MUCCI, Alfredo. A arte do mosaico - compêndio históricotécnico da arte musiva. Rio de Janeiro: Ao Livro Técnico, 1962.

SEVERINO, Antônio Joaquim. Metodologia do trabalho científico. São Paulo: Cortez, 2002.

SITTE, Camillo. A construção das cidades segundo seus princípios artísticos. São Paulo: Editora Ática, 1992. 
TASSINARI, Alberto. O espaço moderno. São Paulo: Cosac \& Naify Edições, 2001.

TOZZI, Cláudio José. O processo de construção da imagem e sua aplicação, relação com o espaço urbano: arte no lugar da arquitetura no fazer de um artista plástico/ arquiteto. São Paulo: tese de doutoramento. Faculdade de Arquitetura e Urbanismo da Universidade de São Paulo, 2001.

ZERBST, Rainer. Gaudí 1852 - 1926 :Antoni Gaudí Cornet Uma vida na arquitectura. Japão: Taschen, 1985.

ZEVI, Bruno. Saber ver a arquitetura. São Paulo: Martins Fontes, 1992.

ZILIO, Carlos. A querela do Brasil. A questão da identidade da arte brasileira: a obra de Tarcila, Di Cavalcanti e

Portinari/1922-1945. Rio de Janeiro: Funarte, 1982.

\section{Periódicos}

BARROS, André Luiz. "Uma relíquia modernista". Jornal do Brasil, Rio de Janeiro, 19 de fev. de 1997.

CAMPOBELO, Humberto. "Das termas de Caracalla às piscinas de hoje”. Casa e Jardim (26): 22-28, jun. 1956. 
CICCACIO, Ana Maria. "Em têmpera, mosaico e vidro". Urbs, São Paulo, (28): 51-54, out/nov., 2002.

"Como tornar-se um mosaicista". Casa e Jardim, (42): 62-70, mai. 1958.

KRÜSE, Olney. "Um retrato do Chico Buarque das artes visuais". Jornal da Tarde, São Paulo, 16 de fev. de 1980.

LORES, Raul Juste. "Centro esquece murais de Di". Folha de S. Paulo, São Paulo, 4 de jun. de 2006.

MARTINS, Ibiapaba de Oliveira. "O desprezo pela pintura mural em S. Paulo". Correio Paulistano, São Paulo, 07 de jun. de 1947.

MELENDEZ, Adilson. "Elegância e originalidade internas, discrição na face externa". Projeto Design, São Paulo, (241): 46-51, mar., 2000.

"Mosaico". Casa e Jardim, (73): 36-38, ago. 1974.

MELO, Magda M. "Síntese das artes na arquitetura de Oscar Niemeyer". Semina: Ciências Sociais e Humanas, Londrina, (24): 121-130, set. 2003.

MOURA, Rodrigo. "Obra pioneira e Di Cavalcanti em Juiz de Fora é tombada pelo Iphan". Folha de S. Paulo, São Paulo, 23 de jun. de 2001. 
TOZZI, Claudio. "Por uma fusão de arquitetura e artes plásticas”. O Estado de São Paulo, São Paulo, 16 de setembro de 2001.

\section{Documentos em sites da internet}

\section{ALDEMIR MARTINS:}

http://www.itaucultural.org.br/aldemirmartins/

Antigo Hotel Jaraguá é reinaugurado no centro - Terra - SP

450 anos: http://sp450anos.terra.com.br/interna/0,,Ol259644-

El2551,00.html

CLAUDIO TOZZI - SITE OFICIAL: http://www.art-

bonobo.com/claudiotozzi/

DI CAVALCANTI: http://www.dicavalcanti.com.br/

HOTEL COMODORO:

http://www.hotelcomodoro.com.br/convsala.htm

HUNDERTWASSER:

http://www.kunsthauswien.com/english/hundertwasser.htm INSTITUTO TOMIE OHTAKE - A ARTISTA E SUAS OBRAS: http://www.institutotomieohtake.org.br/tomie/tetomie.htm 
NEWSMAKER OF THE WEEK: JOHN QUIGLEY:

http://www.scvhistory.com/scvhistory/signal/newsmaker/sg020 104.htm

S.FARO: http://paginas.terra.com.br/arte/sfaro/

TAMAGOTCHI CONNECTIONS: http://www.tamagotchi.com/ VIDROTIL - PAINEL DE VIK MUNIZ NO CENTRO

EMPRESARIAL ITAÚSA:

http://www.arcoweb.com.br/empresas/vidrotil/boletim6.asp

VIK MUNIZ: http://www.vikmuniz.net

WIKIPÉDIA: http://www.wikipedia.org/

\section{Material gravado em CD de áudio}

Mosaico. Marcelo Quintanilha. Mosaico. Faixa 1, Casa da Canção Produções Artísticas e Páginas do Mar Publicidade e Edições Musicais, 2005. 


\section{Material gravado em vídeo}

Ilusões fotográficas de Vik Muniz. Dir. Cacá Vicalvi e Zezo Cintra. Documenta Video Brasil. São Paulo, 2003. 


\section{Lista de figuras}

Figura 1 - Desenho de M. C. Escher com pássaros, onde é possível observar o padrão geométrico. (Fonte: www.mcescher.com)

Figura 2 - Mosaico de pastilha cerâmica de Paulo Werneck na Igreja da Pampulha. (Foto de José Carlos Rodrigues)

Figura 3 - Quarto por varrer, de Sosos de Pérgamo, II a.C...17

Figura 4 - Mosaico aplicado no Parque Güell, de Antoni Gaudí. (Fonte: ZERBST, Rainer. Gaudí 1852 - 1926: Antoni Gaudí Cornet - Uma vida na arquitectura. Japão: Taschen, 1985.)

Figura 5 - Mosaico de janelas no edifício residencial Hundertwasser House, Viena, 1983-1986. (Fonte: www.kunsthauswien.com/english/hundertwasser.htm) ..21

Figura 6 - Mosaico de telhas na Igreja de Santa Bárbara em Bärnbach, 1984-1988. (Fonte: www.kunsthauswien.com/english/hundertwasser.htm) ..21

Figura 7 - Mosaico decorativo em piscina com o tema golfinhos. (Fonte: arquivo da Mosaico Objeto de Arte, fotos de Sérgio Secches)

Figura 8 - Mesa com tampo em mosaico. (Fonte: arquivo da Mosaico Objeto de Arte, foto de Sérgio Secches) .....23

Figura 9 - Patchwork, mosaico feito com pedaços de tecido. (Fonte: www.wikipedia.org/)

Figura 10 - Mosaico de miçangas feito por índios dos EUA. (Foto da autora)....

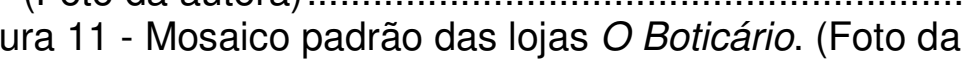
autora) 
Figura 12 - Detalhe do site do O Boticário. (Fonte: www.boticario.com.br) ....

Figura 13 - Personagens Tamagotchi ao lado de suas versões com pixels aparentes. (Fonte: www.tamagotchi.com)

Figura 14 - Animal de estimação virtual Tamagotchi em seu dispositivo. (Fonte: www.tamagotchi.com)

Figura 15 - Mosaico de luzes no edifício sede das Nações Unidas. (Foto de Evan Schneider, fonte: www.un.org) ..31

Figura 16 - Vista da cidade de Nova lorque com o mosaico das Nações Unidas. (Foto de Eskinder Debebe, fonte: www.un.org)

Figura 17 - Mosaico humano de John Quigley em Miami Beach. (Foto de Peter Andrew Bosch, fonte: http://www.scvhistory.com/scvhistory/signal/newsmake $\mathrm{r} / \mathrm{sg} 020104 . \mathrm{htm})$

Figura 18 - Detalhe de mosaico humano. (Foto de Peter Andrew Bosch, fonte:

http://www.scvhistory.com/scvhistory/signal/newsmake r/sg020104.htm)

Figura 19 - Mosaico do Edifício Verona. (Foto da autora) .....37

Figura 20 - Detalhe do mosaico do Edifício Santa Rosa de Lima. (Foto da autora).

Figura 21 - Mosaico de pastilha cerâmica do Edifício Santa Rosa de Lima, de Heinz Kuhn. (Foto da autora)

Figura 22 - Painel em mosaico de pastilha de vidro de Sérgio Secches. (Foto da autora)

Figura 23 - Peça em mosaico de lâminas de vidro fundidas de Gustavo Benini. (Foto da autora)

Figura 24 - Projeto do mosaico Bromélias. (Fonte: arquivo pessoal) 
Figura 25 - Fondling, A.S.T. 180x60cm, 2005. (Foto da autora)

Figura 26 - Laços, A.S.T. 100x80cm, 2006. (Foto da autora)

Figura 27 - Pastilhas utilizadas na composição do mosaico Laços. (Foto da autora)

Figura 28 - Imagem simulando um mosaico através de recurso de edição de imagem em computador. (Fonte: arquivo pessoal)

$$
\text { arquivo pessoal) }
$$

Figura 29 - Torquês para corte de pastilhas de vidro. (Foto da autora)

Figura 30 - Seqüência de colocação das pastilhas em uma parte do mosaico Laços. (Fotos da autora)

Figura 31 - Colagem do papel sobre o mosaico. (Foto de Rute Bevilaqua)

Figura 32 - Colocação do mosaico sobre sua superfície definitiva. (Foto de Rute Bevilaqua)

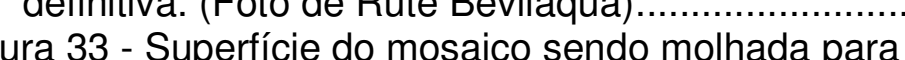
soltar a cola. (Foto de Rute Bevilaqua) .........................52

Figura 34 - Retirada do papel. (Foto de Rute Bevilaqua) ......52

Figura 35 - Painel em mosaico Laços finalizado. (Foto da autora)

ura 36 - Capela antes da implantação do mosaico.

(Foto da autora)

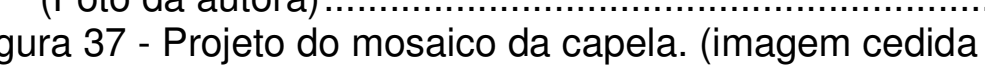
pelo artista)

Figura 38 - Fotomontagem prevendo a aplicação do mosaico na capela. (Imagem cedida pelo artista) ...........55

Figura 39 - Mosaicistas trabalhando na colocação das pastilhas. (Fotos da autora)

Figura 40 - Claudio Tozzi (na escada) e Sérgio Secches visualizando o mosaico. (Foto da autora). 
Figura 41 - Colagem das pastilhas no papel. (Foto de Sérgio Secches)

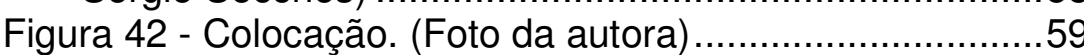

Figura 43 - Retirada do papel. (Foto da autora) ....................59

Figura 44 - Capela com o mosaico finalizado. (Foto de Claudio Tozzi).

Figura 45 - Mosaico de Sérgio Secches, vencedor do concurso promovido pelos Correios. (Foto de Sérgio Secches)

Figura 46 - Mosaico de Sérgio Secches, vencedor do concurso promovido pelos Correios. (Foto de Sérgio Secches)

Figura 47 - Painel em mosaico com pastilhas azuis e

vermelhas de Sérgio Secches. (Foto da autora) .............
igura 48 - Painel baseado no Retrato de Marie-Thérèse, de Picasso, executado em pastilha de vidro por Sérgio Secches. (Foto da autora)

Figura 49 - Teatro Cultura Artística. (Ilustração da autora).....82

Figura 50 - Teatro Cultura Artística. (Foto da Autora)............83

Figura 51 - Alegoria às Artes. (Reprodução a partir de foto antiga)

Figura 52 - Residência Michel Abujamra. (llustração da autora)

Figura 53 - Residência Michel Abujamra. (Foto da autora) ...86 Figura 54 - Mosaico Cavalos de Clóvis Graciano. (Fotos da autora)

Figura 55 - Hotel Jaraguá. (llustração da autora)

Figura 56 - Hotel Jaraguá. (Foto da autora)

Figura 57 - Detalhe do mosaico de Di Cavalcanti no Hotel Jaraguá. (Foto da autora)....

Figura 58 - Mosaico de Di Cavalcanti no Hotel Jaraguá. (Foto da autora) 
Figura 59 - Residência Olívio Gomes. (llustração da autora)

Figura 60 - Residência Olívio Gomes e jardim. (Foto de Michael Moran. Fonte: ADAMS, William Howard. Roberto Burle Marx: The unnatural art of the garden. New York: The Museum of Modern Art, 1991.) . .93

Figura 61 - Mosaico voltado ao jardim da Residência Olívio Gomes. (Foto da autora)

Figura 62 - Mosaico voltado à sala de jogos da Residência Olívio Gomes. (Foto da autora)

Figura 63 - Mosaico de Roberto Burle Marx na sala de jogos da Residência Olívio Gomes. (Foto da autora) .....95

Figura 64 - Mosaico de Roberto Burle Marx na parede externa da Residência Olívio Gomes. (Foto da autora)..95

Figura 65 - Ambiente com mosaico de Portinari no Centro Empresarial Itaúsa. (Ilustração da autora)

gura 66 - Mosaico de Portinari no ambiente amplo onde está instalado atualmente. (Foto da autora) ....

Figura 67 - Mosaico em seu espaço original. (Fonte: www.hotelcomodoro.com.br/convsala.htm)

Figura 68 - Mosaico de Portinari visto a partir de um piso superior. (Foto da autora).... gura 69 - Mosaico Os Bandeirantes de Cândido Portinari. (Foto da autora) ura 70 - Vista a partir de um dos acessos do Edifício

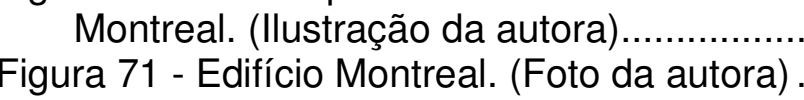
100

Figura 72 - Escada de acesso ao Edifício Montreal pela Av. Ipiranga. (Foto da autora)

Figura 73 - Área interna do Edifício Montreal. (Foto da autora) 
Figura 74 - Mosaico acima da escada da Av. Ipiranga.

(Foto de Peter Caplan)

Figura 75 - Mosaico acima da escada da Av. Cásper

Líbero. (Foto de Peter Caplan)

Figura 76 - Mosaico na parede interna do Edifício Montreal. (Foto da autora)

Figura 77 - Galeria do Edifício Califórnia. (Ilustração da autora)

Figura 78 - Edifício Califórnia. (Foto da autora)

Figura 79 - Mosaico de Portinari no Edifício Califórnia. (Foto da autora).

Figura 80 - Acesso do Edifício Triângulo. (Ilustração da autora)

Figura 81 - Mosaico posicionado acima da escada. (Foto da autora)

Figura 82 - Esquema com Edifício Triângulo em vermelho e as ruas que o cercam em azul.

Figura 83 - Edifício Triângulo. (Foto da autora)

Figura 84 - Acesso do Edifício Triângulo. (Foto da autora) .110

Figura 85 - Mosaico de Di Cavalcanti na parte interna do Edifício Triângulo. (Foto da autora)

Figura 86 - Mosaico de Di Cavalcanti na parte externa do Edifício Triângulo. (Foto da autora)

Figura 87 - Residência na Rua Filadelfo Azevedo. (llustração da autora)

Figura 88 - Detalhe mostrando os bailarinos. (Foto da autora)

Figura 89 - Anúncio da fábrica de pastilhas de vidro Vidrotil mostrando mosaico de Buffoni. (Fonte: Revista Casa e Jardim $n^{\circ} 46$, set./out. 1958)

Figura 90 - Mosaico de Bramante Buffoni na Rua Filadelfo Azevedo. (foto da autora) 
Figura 91 - Acesso norte da Estação Sé do metrô.

(Ilustração da autora)

Figura 92 - Detalhe de Clocha de Retalhos. (Foto da autora)

Figura 93 - Estação Sé. (Foto da autora)

Figura 94 - Estação Sé. (Foto da autora)

Figura 95 - Colcha de Retalhos. (Foto da autora)

Figura 96 - Mosaico de Claudio Tozzi no SESC

Consolação. (llustração da autora)

Figura 97 - Mosaico de Claudio Tozzi no SESC Consolação. (Foto da autora)

Figura 98 - Projeto cromático do painel do SESC

Consolação. (Fonte: TOZZI, Cláudio José. O processo

de construção da imagem e sua aplicação, relação com o espaço urbano: arte no lugar da arquitetura no fazer de um artista plástico/ arquiteto. São Paulo: tese de doutoramento. Faculdade de Arquitetura e Urbanismo da Universidade de São Paulo, 2001.)

Figura 99 - Plataforma de embarque da Estação

Consolação do metrô. (Ilustração da autora)

Figura 100 - Seqüência mostrando painel de Tomie Ohtake visto de dentro do trem e logo após desembarcar. (Fotos da autora)

Figura 101 - Plataforma de embarque. (Fotos da autora)....124

Figura 102 - Vista dos quatro painéis acompanhando toda a extensão da plataforma de embarque. (Foto da autora)

Figura 103 - Projeto dos quatro painéis de Quatro Estações. (Fonte: ARTE NO METRÔ. São Paulo: Companhia do Metropolitano de São Paulo, 1994.) .....125

Figura 104 - Estação Santo André da Companhia Paulista de Trens Metropolitanos. (Ilustração da autora) 
Figura 105 - Detalhe do mosaico de Flemming. (Foto da autora)

Figura 106 - Fachada de vidro da Estação Santo André, através da qual é possível ver o mosaico. (Foto da autora)

Figura 107 - Mosaicos de Alex Flemming da Estação Santo André. (Fotos da autora)

Figura 108 - llustração do ambiente com o mosaico Pastelão na Cultura Inglesa. (Ilustração da autora)......129

Figura 109 - Mosaico Pastelão visto a partir do corredor. (Foto da autora).

Figura 110 - Mosaico ocupando todo o plano da parede que é continuada apenas por vidro. (Foto da autora) ...131

Figura 111 - Detalhe do mosaico Pastelão, onde é possível observar as pastilhas azuis nas linhas e no fundo. (Foto da autora)

Figura 112 - Pastelão. Acrílico sobre tela colada em madeira recortada, $107 \times 145 \mathrm{~cm}$, 1985. (Fonte: KLINTOWITZ, Jacob. Claudio Tozzi: o universo construindo a imagem. Brasil: Valoart, 1989)

Figura 113 - Mosaico Pastelão. (Foto da autora)

Figura 114 - Mosaicos de Herton Roitman na Seguradora Porto Seguro. (llustração da autora)

Figura 115 - Vista geral dos mosaicos na Porto Seguro. (Foto da autora)

Figura 116 - Detalhe do primeiro painel, da esquerda para a direita. (Foto da autora)

Figura 117 - Escultura vista pelo lado direito. (Foto da autora)

Figura 118 - Escultura vista de frente. (Foto da autora) ......136

Figura 119 - Escultura vista pelo lado esquerdo e os três painéis. (Foto da autora) 
Figura 120 - Escultura. (Foto da autora)

Figura 121 - Segundo painel, da esquerda para a direita (Foto da autora.).

Figura 122 - Primeiro painel. (Foto da autora)

Figura 123 - Terceiro painel. (Foto da autora) ....................137

Figura 124 - Anfiteatro do Centro Cultural Dragão do Mar. (llustração da autora)

Figura 125 - Detalhe do mosaico. (Foto de Rosa Cecília Teixeira)

Figura 126 - Detalhe do mosaico, (Foto da autora) .............140

Figura 127 - Detalhe do mosaico junto à rampa. (Foto de Rosa Cecília Teixeira) ....

Figura 128 - Mosaico de Aldemir Martins do Centro Cultural Dragão do Mar. (Foto de Rosa Cecília Teixeira)

Figura 129 - Área de circulação do Novotel. (llustração da autora)

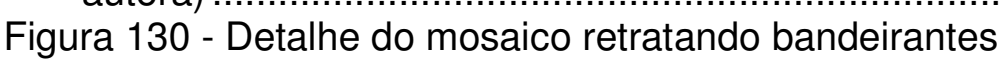
do Novotel. (Foto da autora).

Figura 131 - Piscina do Novotel. (Foto da autora)

Figura 132 - Detalhe do mosaico junto à piscina do Novotel. (Foto da autora)

Figura 133 - Os três painéis de Claudio Tozzi com tema de bandeirantes no Novotel. (Fotos de Peter Caplan)....... 145

Figura 134 - Mosaico de Claudio Tozzi junto à piscina do Novotel. (Foto da autora).

Figura 135 - Terminal de ônibus da Estação Santo Amaro. (llustração da autora)

Figura 136 - Terminal de ônibus da Estação Santo Amaro. (Foto da autora) 
Figura 137 - Detalhe do mosaico onde é possível visualizar os elementos superfície, linha e volume. (Foto da autora)

Figura 138 - Mosaico de Odiléa Toscano no terminal de ônibus de Santo Amaro. (Foto da autora)

Figura 139 - Ilustração da passagem subterrânea no Centro Empresarial Itaúsa. (Ilustração da autora) .........151

Figura 140 - Mosaico de Vik Muniz visto da extremidade superior da rampa. (Foto da autora)

Figura 141 - Mosaico visto da extremidade inferior da rampa. (Foto da autora)

Figura 142 - Detalhe do mosaico. Visto de perto não se pode identificar o desenho. (Foto da autora)

Figura 143 - Detalhe do mosaico. A uma distância um pouco maior é possível identificar um rosto. (Foto da autora)

Figura 144 - Obra de Vik Muniz em chocolate que deu origem ao mosaico. (Fonte:

www.arcoweb.com.br/empresas/vidroti//boletim6.asp, foto de divulgação)

Figura 145 - Edifício Exclusive na Avenida Angélica. (ilustração da autora)...

Figura 146 - Mosaico de Claudio Tozzi no Edifício Exclusive. (Foto da autora)

Figura 147 - Avenida Angélica. (Foto da autora)

Figura 148 - Avenida Angélica. (Foto da autora)

Figura 149 - Perspectiva ilustrando projeto do mural do Ed. Exclusive.

Figura 150 - Entrada do auditório do Fórum Trabalhista. (llustração da autora)

Figura 151 - Interior do Fórum Trabalhista. (Foto de Cristiano Mascaro, arquivo de Claudio Tozzi) 
Figura 152 - Composição de mosaico vista por entre as rampas. (Foto da autora)

Figura 153 - Projeto dos painéis do Fórum Trabalhista.

(Fonte: arquivo do Claudio Tozzi)

Figura 154 - Mosaicos de Claudio Tozzi no Fórum Trabalhista. (Fotos da autora)

Figura 155 - Detalhe de painel de Herton Roitman na Seguradora Porto Seguro. (Foto da autora) 


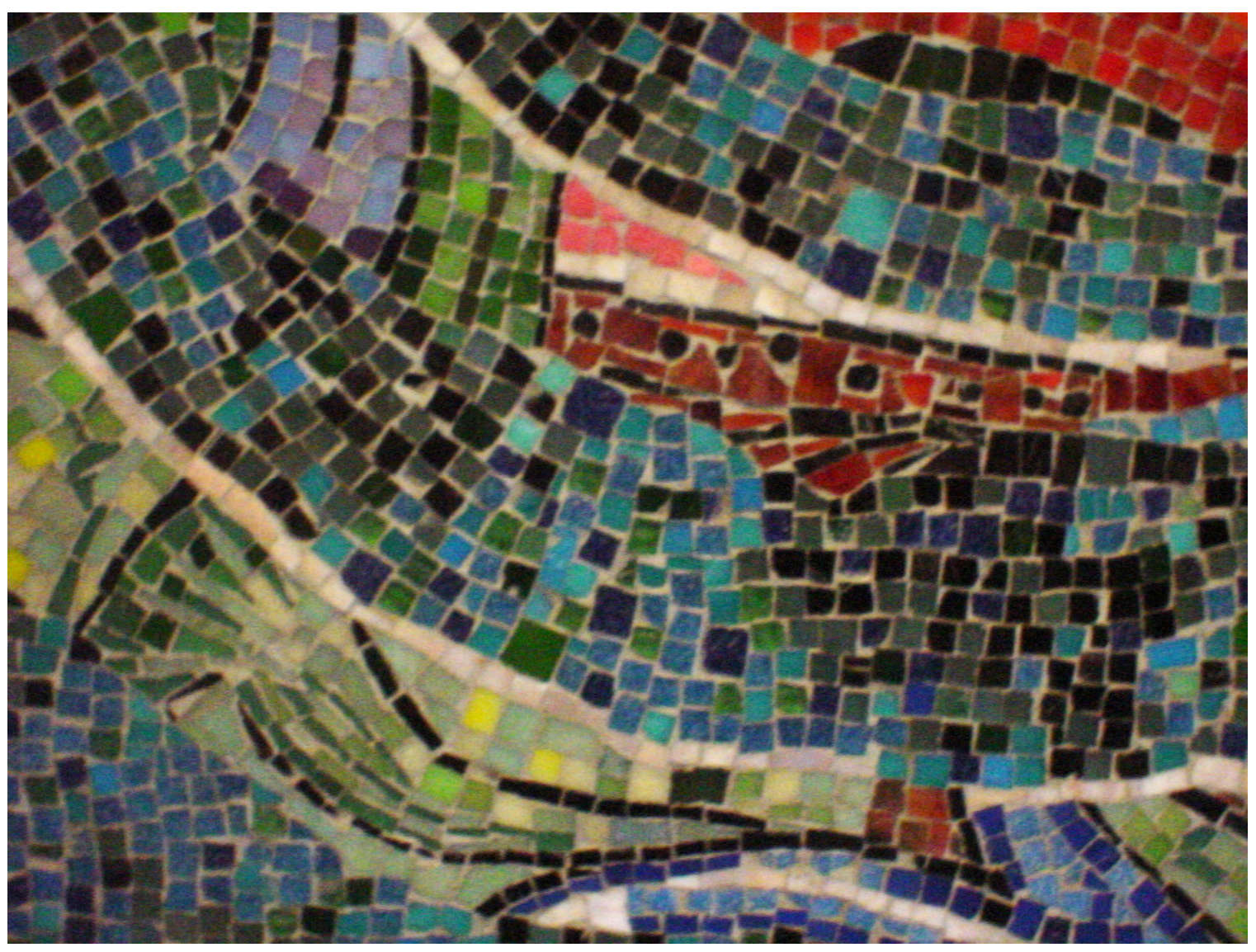

Figura 155 - Detalhe de painel de Herton Roitman na Seguradora Porto Seguro. (Foto da autora) 